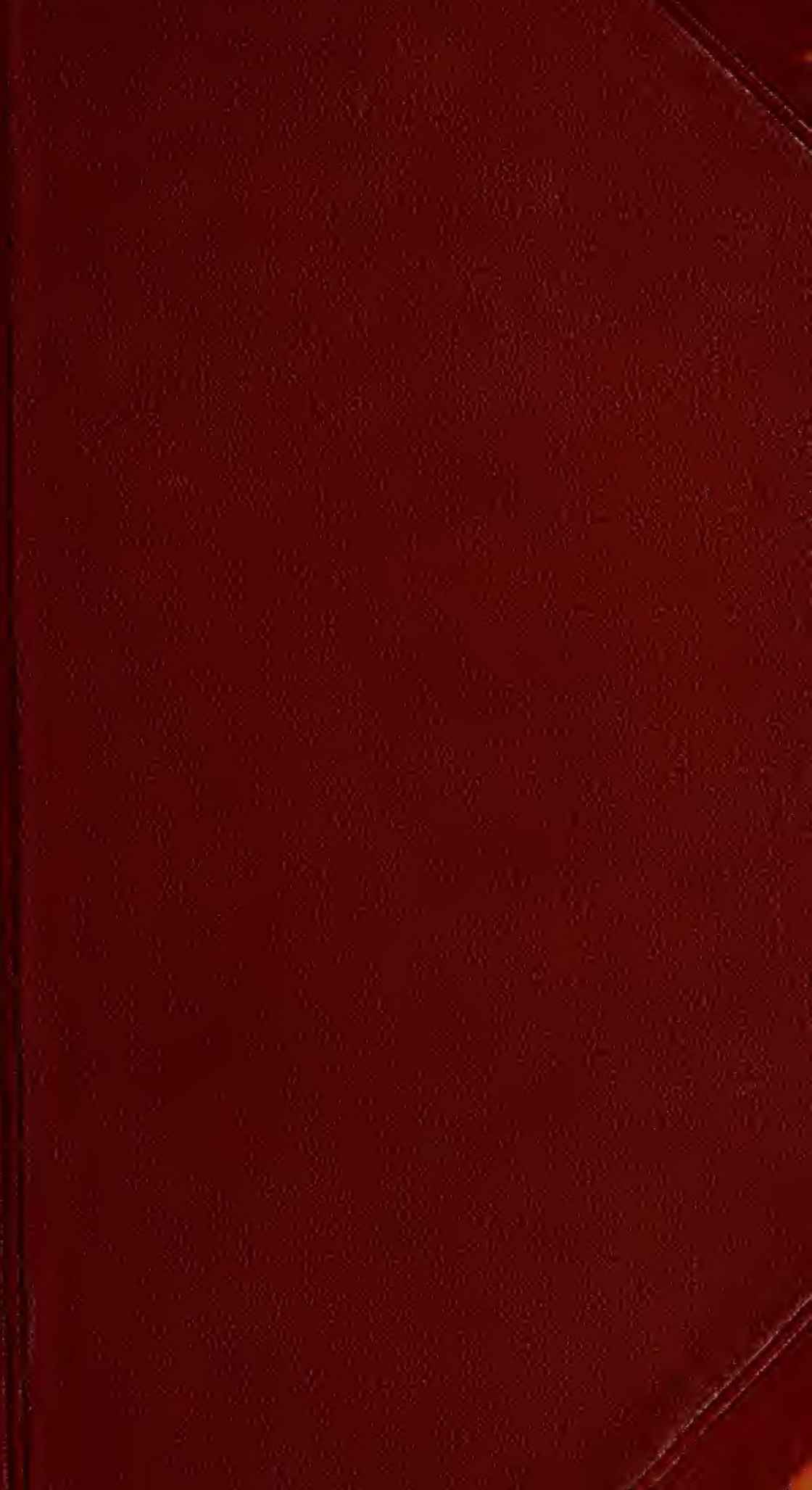



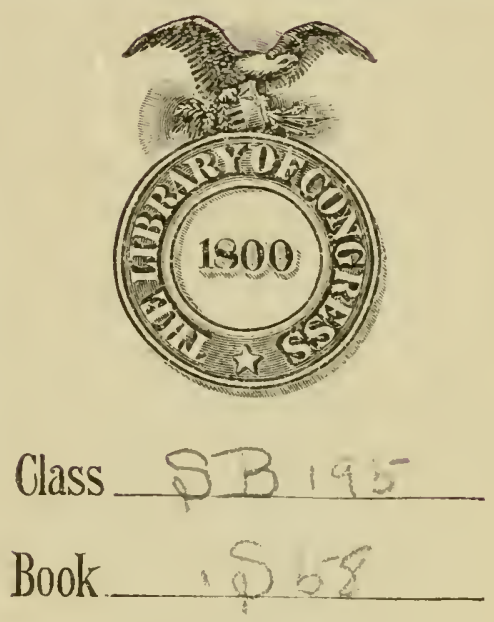

Copyright No.

COPYRIGHT DEPOSIT. 





. 



\section{MODERN SILAGE METHODS}

WITH ILLUSTRATIONS.

An entirely new and practical work on Silos, their construction and the process of filling, to which is added complete and reliable information regarding Silage and its composition; feeding, and a treatise on rations, being a Feeders' and Dairymens' Guide.

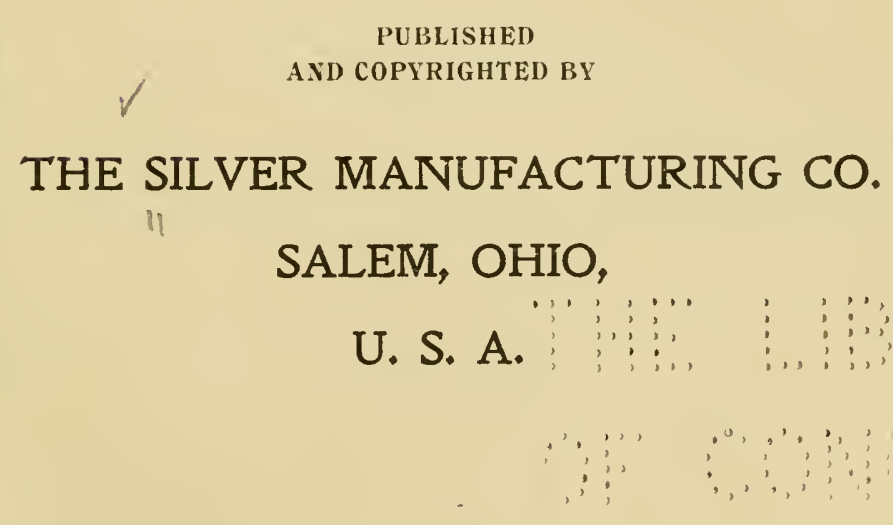

1903. 


$$
\begin{aligned}
& \text { THIE LIERARY OF } \\
& \text { CONGFESS } \\
& \text { Tnin Copies Receivec } \\
& \text { APR } 431903 \\
& \text { áu, 13,1903 } \\
& \text { CLASS a XXC.NO. } \\
& 57352 \\
& \text { COPY } 8
\end{aligned}
$$

Copyrighted 1903, by The Silver Mfg. Co.
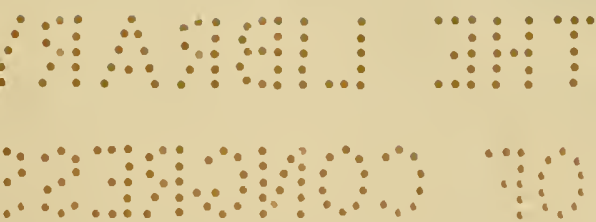


\section{MODERN SILAGE METHODS.}

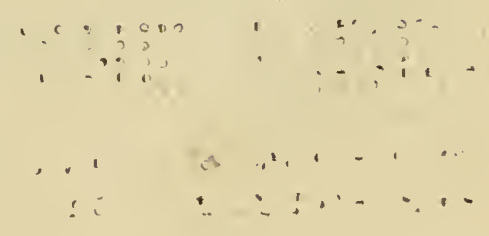




\section{PREFACE.}

This book has been written and published for the purpose of furnishing our patrons and others with accurate and full information on the subject of silo construction and the making of silage. It has been the aim of the authors to present the subject in a clear matter-of-fact manner, without flourish of rhetoric or flights of imagination, believing that the truth concerning the advantages of the siloing system is good enough. The testimony presented, which is purposely kept close to the experiences of authorities on feeding subjects in and outside of experiment stations, will abundantly prove, we believe, that the equipment of an American dairy or stock farm is no longer complete without one or more silos on it.

In order that a work of this kind be accurate and reliable, and bear the scrutiny of scientific readers, the use of a number of scientific terms and phrases is rendered necessary, and in order that these may be more ready comprehended by Agriculturists, a comprehensive glossary or dictionary of such terms is included, following the last chapter, which can be referred to from time to time, or can be studied previous to reading the book.

In the compilation of certain parts of the book we have had the valuable assistance of Prof. Woll, of Wisconsin Experiment Station, author of "A Book on Silage" and "A Handbook for Farmers and Dairymen". Free use of the former book has been made in the preparation of this voltume, as well as of experiment station publications treating the subject of silage.

Hoping that "Modern Silage Methods" will prove help$\therefore$ fuitoostr patrons, and incidentally suggest to them that the OHis silage Cutter aridower Elevators are manufactured by 11 , we are

Very truly,

THE SILVER MFG. CO. 


\section{TABLE OF CONTENTS.}

PREFACE

INTRODUCTION

\section{CHAPTER I.}

Advantages of the Silo-Preservation of a larger quartity of original food value enabled by the use of the Silo than any method known-Losses of nutritive value in dry curing-Small losses in the Siloing process-The Silo furnishes a feed of uniform qualityEconomy of making-Economy of Storage-No danger of rain-No danger of late summer droughts -Food from thistles-Value in intensive farming.

CHAPTER II.

\section{How to Build a Silo.}

Silos-General requirements for silo structures-On the size of silo required-On the form of silosRelation of horizontal feeding-Area and number of cows kept-Location of the silo-Different types of silo structures-Round wooden silos-The silo roof-Modifications of the Wisconsin Silo-Plastered round wooden Silos-Brick-lined Silos-Stave Silos-Cheap Stave Silos-A modification of a Stave Silo-Connecting round silos with the barn-Other forms of round silos-Brick and Stone Silos-Silos in the barn $-A$ small $\$ 30$ Silo-Octagonal SilosCost and estimates for different kinds of Si os.

\section{CHAPTER III.}

Silage Crops-Indian Corn-Soils best adapted to corn culture and preparation of land-Varieties of corn 
for the silo-Time of cutting corn for the siloMethods of planting corn-Other silage crops.

\section{CHAPTER IV.}

Filling the Silo-Indian Corn-Siloing corn "ears and all "-The filling process-The proper distribution of cut material in the silo-Size of cutter and power required-Length of chain elevator required-Directions for operating "Ohio" Blower Cutters-Danger from carbonic-acid poisoning in silos-Covering the siloed fodder-Use of water in filling silos--Clover for summer silage--Freezing of silage.

\section{CHAPTER V.}

How to feed silage--Silage for milch cows-Silage in the production of certified milk-Silage for beef cattle-for Horses-for Sheep-for Swine-Silage for poultry-Additional testimony as to the advantage of silage-Corn silage as compared with root crops--Corn silage as compared with hay-Corn silage compared with fodder corn.

CHAPTER VI.

A feeder's guide--Composition of the animal body-Composition of feeding stuffs--Digestibility of foods -Relative value of feeding stuffs--Feeding standards-How to figure out rations- Grain mixtures for dairy cows-Average composition of Silage crops of different kinds, in per cent-Analysis of Feeding stuffs-Ready reference tables.

CONCLUSION. 


\section{Modern Silage Methods.}

\section{INTRODUCTION.}

Twenty years ago few farmers knew what a silo was, and fewer still had ever seen a silo or fed silage to their stock. Today silos are as common as barn buildings in many farming districts in this country, and thousands of farmers would want to quit farming if they could not have silage to feed to their stock during the larger portion of the year. Twenty years ago it would have been necessary to begin a book describing the siloing system with definitions, what is meant by silos and silage : now all farmers who read agricultural papers or attend agricultural or dairy conventions are at least familiar with these words, even if they had not had a chance to become familiar with the appearance and properties of silage. They know that a SILO is an air-tight structure used for the preservation of green, coarse fodders in a succulent condition, and that SILAGE is the feed taken out of a silo.

We shall later see which crops are adapted for silage making, but want to state here at the outset that Indian corn is pre-eminently the American crop suited to be preserved in silos, and that this crop is siloed far more than all other kinds of crops put together. When the word silage is mentioned we, therefore, instinctively think of corn silage. We shall also follow this plan in the discussions in this book; when only silage is spoken of we mean silage made from the corn plant; if made from other crops the name of the crop is always given, as clover silage, peavine silage, etc.

History of the silo. While the silo in one form or another dates back to antiquity, it was not until the 
latter part of the seventies that the building of silos intended for manufacture of silage began in this country. In I $8 S_{2}$ the United States Department of Agriculture could find only ninety-one farmers in this country who used silos." During the last twenty years, however, silos have gradually become general in all sections of the country where dairying and stock-raising are important industries; it is likely, if a census were taken of the number of silos in this county today, that we would find between a third and a half million of them. The silo is today considered a necessity on thousands of dairy farms, and we find most of them in the states that rank first as dairy states, viz: New York, Iowa, Illinois, Wisconsin, Pennsylvania, etc. The farmers that have had most experience with silage are the most enthusiastic advocates of the siloing system, and the testimony of intelligent dairymen all over the country is strongly in favor of the silo. Said a New York farmer recently in one of our main agricultural papers: "I would as soon try to farm without a barn as without a silo," and another wrote "I wouldn't take a thousand dollars for my silo if I could not replace it." The well-known agricultural writer, Joseph E. Wing, says, "No stock feeder who grows corn can afford to ignore the silo." "Buff Jersey," an Illinois dairy farmer and writer on agricultural topics, declares his faith in silage as follows: "I am fully satisfied that silage is a better feed, and a cheaper one, than our pastures." Another writer says: "The silo to my mind presents so many advantages over the system of soiling that it is bound to eventually do away with the use of soiling crops." According to the Cornell Experiment Station, "the silo, especially to the dairy farmer, lias become an almost necessary adjunct to the equipment of the farm."

Our first effort in writing this book will be to present facts that will back up these statements, and how the reader the many advantages of the silo over $\mathrm{S}$ 
other systems of growing and curing crops for the feeding of farm animals. We shall show that up-todate dairy or stock farming is well nigh impossible without the aid of a silo. The silo enables us to feed live stock succulent feeds the year around, and preserves the fodder in a better condition and with less waste than any other system can. We shall see the why and wherefore of this in the following pages, and shall deal with the best way of making and feeding silage to farm animals. We wish to state at the outset that we do not propose to indulge in unwarranted statements or claims that will not stand the closest investigation. In the early days of the history of the silo movement it was thought necessary to make exaggerated claims, but this is no longer the case. Naked facts are sufficient to secure for the silo a permanent place among the necessary equipment of a modern dairy or stock farm. In discussing the silo we shall keep close to what has been found out at our experiment stations, and, we believe, shall be able to prove to any fair-minded reader that the silo is the greatest boon that has come to modern agriculture since the first reaper was manufactured, and that with competition and resulting low prices, it will be likely to become more of a necessity to our farmers in the future than it has been in the past. We aim to convince our readers that the most sensible thing they can do is to plan to build a silo at once if they do not now have one. It is unnecessary to argue with those who are already the happy possessors of a silo, for it is a general experience where a farmer has only provided for immediate wants in building his silo that he will build another as soon as he has had some experience with silage and finds out how his stock likes it, and how well they do on it.

Modern practice has proved that no man need say "I cannot afford a silo," because any farmer who is at all handy with hammer and saw can provide a silo 
large enough for a medium-sized dairy with very little actual outlay of money. And this same built-at-home silo will earn fo: its owner money to build another, and enlarge his herd.

We shall give directions for building several kinds of such silos on the following pages. While they will not be apt to last as long, and therefore are not perhaps as economical in the long run as more substantially-built silos, still they do excellent service until some experience with making and feeding silage has been obtained, or until the farmer can afford to put up a more substantial structure.

We mention this fact here to show farmers who may be considering the matter of building a silo, or who may be inclined to think that the silo is an expensive luxury, only for rich farmers, that the cost of a silo need not debar them from the advantages of having one on their farm, and thus secure a uniform succulent feed for their stock through the whole winter. Farmers who have not as yet informed themselves in regard to the value of the silo and silage on dairy or stock farms, are respectfully asked to read carefully the following statements of the advantages of the silo system over other methods of preserving green forage for winter or summer feeding.

It has been said "Whoever makes two blades of grass grow where but one grew before is a benefactor to mankind." A silo makes it possible to keep two cows where but one was kept before, and who would not gladly double his income? Does not this interest you? 


\section{CHAPTER I.}

\section{ADVANTAGES OF THE SILO.}

1. The silo enables us to preserve a larger quantity of the food materials of the original fodder for the feeding of farm animals than is possible by any other system of preservation now known. Pasture grass is the ideal feed for live stock, but it is not available more than a few months in the year. The same holds true with all soiling crops or tame grasses as well. When made into hay the grasses and other green crops lose some of the food material contained therein, both on account of unavoidable losses of leaves and other tender parts, and on account of fermentations which take place while the plants are drying out or being cured.

In case of Indian corn the losses from the latter source are considerable, owing the coarse stalks of the plant and the large number of air-cells in the pith of these. Under the best of conditions cured fodder corn will lose at least ten per cent. of its food value when cured in shocks; such a low loss can only be obtained when the shocks are cared for under cover, or out in the field under ideal weather conditions. In ordinary farm practice the loss in nutritive value will approach twenty-five per cent., and will even exceed this figure unless special precautions are taken in handling the fodder, and it is not left exposed to all kinds of weather in shocks in the field through the whole winter. These figures may seem surprisingly large to many farmers who have left fodder out all winter long, and find the corn in the inside of the shock bright and green, almost as it was when put up. But appearances are deceitful; if the shocks had been weighed as they were put up. and again in the late winter, another story would be told, and it would be found 
that the slocks only weighed anywhere from a third to a half as much as when they were cured and ready to be put in the barn late in the fall; if chemical analyses of the corn in the shocks were made in the fall, and when taken down, it would be found that the decrease in weight was not caused by evaporation of water from the fodder, but by waste of food materials contained therein from fermentations, or the action of enzymes. (See Glossary.)

The correctness of the figures given abore has been abundantly proved by careful experiments conducted at a number of different experiment stations, notably the IVisconsin, New Jersey, Vermont, Pennsylvania, and Colorado experiment stations. A summary of the main work in this line is given in Prof. Woll's Book on Silage. In the Wisconsin experiments there was an average loss of 23.8 per cent. in the dry matter (see Glossary), and 24.3 per cent of protein, during four different years, when over 36 tons of green fodder had been put up in shocks and carefully weighed and sampled at the beginning and end of the experiment. These shocks had been left ont for different lengths of time, linder varying conditions of weather, and made from different kinds of corn, so as to present a variety of conditions. The Colorado experiments are perhaps the most convincing as to the losses which unavoidably take place in the curing of Indian corn in shocks. The following account is taken from Prof. Cook's report of the experiments. As the conditions described in the investigation will apply to most places on our continent where Indian corn is cured for fodder, it will be well for farmers to carefully look into the results of the experiment.

"It is believed by most farmers that, in the dry climate of Colorado, fodder corn, where cut and shocked in good shape, cures without loss of feeding value, and that the loss of weight that occurs is merely due to the drying out of the water. A test of this question was 
made in the fall of $I 893$, and the results obtained seemed to indicate that fully a third of the feeding value was lost in the curing. This result was so surprising that the figures were not published, fearing that some error had crept in, though we could not see where there was the possibility of a mistake.

"In the fall of $\mathrm{I} 894$ the terst was repeated on a larger scale. A lot of corn was carefully weighed and sampled. It was then divided into three portions: one was spread on the ground in a thin layer, the second part was set up in large shocks, containing about five hundred pounds of green fodder in each, while the rest was shocked in small bundles. After remaining thus for some months, until thoroughly cured, the portions were weighed, sampled, and analyzed separately. The table gives the losses that occurred in the curing.

\begin{tabular}{|c|c|c|c|c|c|c|}
\hline r & \multicolumn{2}{|c|}{ Large Shocks. } & \multicolumn{2}{|c|}{ Small Shocks. } & \multicolumn{2}{|c|}{ On te Ground } \\
\hline & $\begin{array}{c}\text { Total } \\
\text { Weight }\end{array}$ & $\begin{array}{c}\text { Dry } \\
\text { Matter. }\end{array}$ & $\begin{array}{c}\text { Total } \\
\text { Weiglit }\end{array}$ & $\begin{array}{c}\text { Dry } \\
\text { Matter- }\end{array}$ & $\begin{array}{c}\text { Total } \\
\text { Weiglit }\end{array}$ & $\begin{array}{l}\text { Dry } \\
\text { Matter: }\end{array}$ \\
\hline & L.bs. & L bs. & L bs. & Libs. & Lus. & Lbs. \\
\hline When Shocked...... & 952 & 217 & 294 & 77 & 186 & 42 \\
\hline After Curing . . . . . . . & 258 & 150 & 64 & 44 & 33 & 19 \\
\hline Loss in Weight.. & 694 & 67 & 230 & 33 & 153 & 23 \\
\hline Per Cent. of Loss. & 73 & 31 & 78 & 43 & 82 & 55 \\
\hline
\end{tabular}

"So far as could be told by the eye, there had been no loss. The fodder had cured in nice shape, and the stalks on the inside of the bundles retained their green color, with no sign of molding or heating. And yet the large shocks had lost 3 I per cent. of their dry matter, or feeding value; the small shocks 43 per cent. and the corn spread on the ground 55 per cent.

"On breaking or cutting the stalks these losses were explained. The juice was acid, and there was a very strong acid odor, showing that an active fermentation was taling place in this seemingly dry fodder. 
We had noticed this strong odor the fall before and all through the winter. When the fodder corn for the steers is put through the feed cutter that same strong smell is present.

"It can be said, then, that the dryness of the climate in Colorado does not prevent fodder corn from losing a large part of its feeding value through fermentation. Indeed, the loss from this source is fully as great as in the damp climate of New England.

"As compared with the losses by fermentation in the silo, the cured fodder shows considerably the higher loss.'

In experiments at the Wisconsin station eleven shocks cured under cover in the barn lost on an average over 8 per cent. of dry matter and toward it per cent. of protein. In an experiment at the Maine Station over 14 per cent. of dry matter was lost in the process of slow drying of a large sample of fodder corn under the most favorable circumstances. "It is interesting to note that this loss falls almost entirely on the nitrogen-free extract, or carbohydrates (see Glossary), more than two-thirds of it being actually accounted for by the diminished percentage of sugars."

Since such losses will occur in fodder cured under cover with all possible care, it is evident that the average losses of dry matter in field-curing fodder corn, given in the preceding, by no means can be considered exaggerated. Exposure to rain and storm, abrasion of dry leaves and thin stalks, and other factors tend to diminish the nutritive value of the fodder, aside from the losses from fermentations, so that very often only one-half of the food materials originally present in the fodder is left by the time it is fed out. The remaining portion of the fodder has, furthermore, a lower digestibility and a lower feeding value than the fodder corn when put up, for the reason that the fermentations occurring during the curing process destroy the most valuable and easily digestible part, i.e., 
the sugar and starch of the nitrogen-free extract, which are soluble, or readily rendered soluble, in the process of digestion.

2. Losses in the Siloing Process. As compared witl the large losses in food materials in field-curing of Indian corn there are but comparatively small losses in the silo, caused by fermentation processes, or decomposition of the living plant cells as they are dying off. The losses in this case have been repeatedly determined by experiment stations, and, among others, by those mentioned in the preceding. The average losses of dry matter in the fodder corn during the siloing period of four seasons (I887-'9I) as determined by Prof. Woll at the Wisconsin Experiment Station was about i6 per cent. The silos used in these trials, as in case of nearly all the early experiments on this point, were small and shallow, however, only i 4 feet deep, were rectangular in form, and not always perfectly air-tight, a most important point in silo construction, as we shall see, and a portion of the silage therefore came out spoilt, thus increasing the losses of food materials in the siloing process. The losses reported were, therefore, too great, and there is now an abundance of evidence at hand showing that the figures given are higher than those found in actual practice, and the necessary loss in the silo comes considerably below that found in the early experiments on this point. There are plenty of cases on record showing that ten per cent. represents the maximum loss of dry matter in modern deep, well-built silos. The losses found in siloing corn at a number of experiment stations during the last ten years have come at or below this figure. It is possible to reduce this loss still farther by aroiding any spoilt silage on the surface, by beginning to feed immediately after the filling of the silo, and by feeding the silage out rather rapidly. Experiments conducted on a small scale by Prof. King in I 894 gave losses of only 2 and 3 per cent. of dry 
matter, on the strength of which results, anongst others, he belieres that the necessary loss of dry matter in the silo need not cxceed 5 per cent.

Summarizing our considerations concerning the relative losses of food materials in the field-curing and siloing of Indian corn, we may, therefore, say that far from being less economical than the former, the silo is more so, under favorable conditions for both systems. and that therefore a larger quantity of food materials is obtained by filling the corn crop into a silo than by any other method of preserving it known at the present time.

What has been said in the foregoing in regard to: fodder corn applies equally well to other crops put into the silo. A few words will suffice in regard to two of these, clover and alfalfa. Only a few accurate siloing experiments have been conducted with clover, but enough has been done to show that the necessary losses in siloing this crop do not much, if any, exceed those of Indian corn. Lawes and Gilbert, of the Rothamsted Experiment Station, England, placed 264,3 I 8 pounds of first- and second-crop clover into one of their stone silos, and took out I 94,470 pounds of good clover silage. Loss in weight, 24.9 per cent. This loss fell, however, largely on the water in the clover. The loss of dry matter amounted to only 5.I per cent., very nearly the same amount of loss as that which the same experimenter found had taken place in a large rick of about forty tons of hay, after standing for two years. The loss of protein in the silo amounted to 8.2 per cent. In another silo I 84,959 pounds of second-crop grass and second-crop clover were put in, and i70,94I pounds were taken out. Loss in gross weight, 7.6 per cent.; loss of dry matter 9.7 per cent.; of crude protein 7.8 per cent.

In a siloing experinent with clover, conducted at the Wisconsin Station, on a smaller scale, Mr. F. G. Short obtained the following results: Clorer put into 
the silo, I 2,279 pounds; silage taken out, 9,283 pounds; loss, 24.4 per cent.; loss of dry matter, I 5.4 per cent.; of protein, 12.7 per cent.

There is nothing in any of these figures to argue against the siloing of green clover as an economical practice. On the other hand, we conclude that this method of preserving the clover crop is highly valuable, and, in most cases, to be preferred to making hay of the crop.

No extended investigation has been made as to the osses sustained in the siloing of alfalfa, but there can be little doubt but that they are considerably smaller than in making alfalfa hay, if proper precautions guarding against unnecessary losses in the silo are taken. According to the testinnony of Professor Headden of the Colorado Experinent Station, the 11111imum loss from the falling off of leares and stems in successful alfalfa hay making amounts to from 15 to 20 per cent., and in cases where the conditions have been unfavorable, to as much as 60 and even 66 per cent. of the hay crop. Aside from the losses sustained through abrasion, rain storms, when these occur, may reduce the value of the hay one-half. The losses from either of these sources are avoided in preserving the crop in the silo, and in their place a sniall loss through fermentation occurs, under ordinary favorable conditions, amounting to about io per cent or less.

There is this further advaritage to be considered when the question of relative losses in the silo and in hay-making or field-curing green forage, that hay or corn fodder, whether in shocks in the field or stored under shelter, gets poorer and poorer the longer it is kept, as the processes of decomposition are going on all the time: in the silo, on the other hand, the loss in food substances is not appreciably larger six months after the silo was filled than it is one 1nonth after, because the air is shut out, so that the farmer who puts up a lot of fodder corn for silage in the fall can have 
as much and as valuable feed for his stock in the spring, or in fact, the following summer or fall, as he would have if he proceeded to feed out all the silage at once.

"Generally speaking, 3 tons of silage are equal in feeding value to I ton of hay. On this basis a much larger amount of digestible food can be secured from an acre of silage corn thin from an acre of hay. The food equivalent of 4 tons of hay per acre can easily be produced on an acre of land planted to corn.'”(Plimb).

3. Succulence. Succulent food is Nature's food. We all know the difference between a juicy, ripe apple and the dried fruit. In the drying of fruit as well as of green fodders water is the main component taken away; with it, however, go certain flavoring matters that do not weigh much in the chemist's balance, but are of the greatest importance in rendering the food materials palatable. It is these same flavoring substances which are washed out of hay with heavy rains, and renders such hay of inferior value, often no better than so much straw, not because it does not contain nearly as much food substances, like protein, fat, starch, sugar, etc. (see Glossary), but because of the substances that render hay palatable having been largely removed by the rain.

The influence of well-preserved silage on the digestion and general health of animals is very beneficial, according to the unanimous testimony of good authorities. It is a mild laxative, and acts in this way very similarly to green fodders. The good accounts reported of the prevention of milk fever by the feeding of silage are explained by the laxative influence of the feed.

4. Uniformity. The silo tumishes a feed of uniform quality, and always near at hand, available at any time during the whole year or winter. No need of fighting the elements, or wading througli snow or mud to haul 
it from the field; once in the silo the hard work is over, and the farmer can rest easy as to the supply of succulent roughage for his stock during the winter. An ample supply of succulent feed is of advantage to all classes of animals, but perhaps particularly so in case of dairy cows and sheep, since these animals are especially sensitive to sudden changes in the feed. Also, stock raisers value silage highly on this account, however, for silage is of special value for feeding preparatory to turning cattle on to the watery pasture grass in the spring. The loss in the weiglit of cattle on being let out on pasture in spring, is often so great that it takes them a couple of weeks to get back where they were when turned out. When let out in the spring, steers will be apt to lose weight, no matter whether silage or dry feed has been fed, unless they are fed some grain during the first week or two after they are turned out.

5. Economy of Storage. Less room is required for the storage in a silo of the product from an acre of land than in cured condition in a barn. A ton of hay stored in the mow will fill a space of at least 400 cubic feet; a ton of silage, a space of about 50 cubic feet. Considering the dry matter contained in both feeds, we have that 8,000 pounds of silage contains about as much dry matter as 2.323 pounds of hay, or I 60 against 465 cubic feet; that is, it takes nearly three times as much room to store the same quantity of food materials in hay as in silage. In case of field-cured fodder corn, the comparison comes out still more in favor of the silo, on account of the greater difficulty in preserving the thick cornstalks from heating when placed under shelter. According to Professor Alvord, an acre of corn, field-cured, stored in the most compact manner possible, will occupy a space ten times as great as in the form of silage. While hay will contain about 86 per cent. of dry matter, cured fodder corn often does not contain more than 60 and sometimes only 50 per cent. of 
dry matter; the quantities of food material in fodder corn that can be stored in a given space are, therefore, greatly smaller than in case of hay, and, consequently, still smaller than in case of silage.

Since smaller barns may be built when silage is fed, there is less danger of fire, thus decreasing the cost of insurance.

6. No Danger of Rain. Rainy weather is a disadvantage in filling silos as in most other farm operations, but when the silo is once filled, the fodder is safe, and the farmer is independent of the weather throughout the season.

If the corn has suffered from drought and heat dur. ing the fall months, it is quite essential to wet the corn either as it goes into the silo, or when this has been all filled, in order to secure a good quality of silage; and unless the corn is very green when it goes into the silo, the addition of water, or water on the corn from rain or dew, will do no harm. If the corn is too dry when put into the silo, the result will be dry mold, which is prevented by the addition of the water, which replaces that which has dried out previous to filling if this has been delayed.

A common practice among successful siloists is to fill the silo when the lower leaves of the standing corn have dried up about half way to the ears. Generally, the oorn will be in about the proper condition at that time, and there will still be moisture enough left in the plants so that the silage will come out in first-class condition.

There must be moisture enough in the corn at time of filling the silo, so that the heating processes, which take place soon after, and which expel a considerable portion of moisture, can take place, and still leave the corn moist after cooling, when the silage will remain in practically a uniform condition for several years if left undisturbed. But if, on account of over-ripeness, frosts, or excessive drought, the corn is drier than 
stated, it should be made quite wet as stated above, and there is little danger of getting it too wet. The writer has filled a silo with husked corn fodder about Christmas, and as the fodder was thoroughly dried, a $3 / 4$-inch pipe was connected with an overhead tank in the barn and arranged to discharge into the carrier of the cutter as the cutting took place, a No. I 8 Ohio cutter being used for that purpose. Although the full stream was discharged, and with considerable force, on account of the elevation of the tank, and the cut fodder in the silo still further wet on top with a long hose attached to a wind force pump, it was found, on opening the silo a month later, that none too much water had been used; the fodder silage came out in good condition, was eaten greedily by the milch cows, and was much more valuable than if it had been fed dry from the field.

Where haymaking is precluded, as is sometimes the case with second-crop clover, rowen, etc., on account of rainy weather late in the season, the silo will furthermore preserve the crop, so that the farmer may derive full benefit from it in feeding it to his stock. Frosted corn can also be preserved in the silo, and will come out a very fair quality of silage if well watered as referred to above.

7. No Danger of Late-Summer Droughts. By filling the silo with clover or other green summer crops early in the season, a valuable succulent feed will be at haud at a time when pastures in most regions are apt to give out; then again, the silo may be filled with corn when this is in the roasting-ear stage, and the land thus entirely cleared earlier than when the corn is left to mature and the corn fodder shocked on the land, making it possible to finish the fall plowing sooner and to seed the land down to grass or to winter grain.

8. Food from Thistles. Crops unfit for haymaking may be preserved in the silo and changed into a pal- 
atable food. This is not of the importance in this land of plenty of ours that it is, or occasionally has been, elsewhere. Under silage crops are included a number of crops which could not be used as cattle food in any other form than this, as ferns, thistles, all kinds of weeds, etc. In case of fodder famine the silo may thus help the farmer to carry his cattle through the winter.

9. Value in Intensive Farming. More cattle can be kept on a certain area of land when silage is fed than is otherwise the case. The silo in this respect furnishes a similar advantage over field-curing fodders as does the soiling system over that of pasturing cattle; in both the siloing and the soiling system there is 110 waste of feed, all food grown on the land being utilized for the feeding of farm animals, except a small tninaroidable loss in case of the siloing system incurred by the fermentation processes taking place in the silo.

Pasturing cattle is an expensive method of feeding, as far as the use of the land goes, and can only be practiced to advantage where this is cheap. As the land increases in value, more stock must be kept on the same area in order to correspondingly increase the profits from the land. The silo here comes in as a material aid, and by its adoption, either alone or in connection with the soiling system, it will be possible to keep at least twice the number of animals on the land that can be done under the more prinitive system of pasturing and feeding dry feeds during winter. The experience of Goffart, "the Father of Modern Silage," on this point is characteristic. On his farm of less than eighty-six acres at Burtin, France, he kept a herd of sixty cattle, besides fattening a number of steers during the winter, and eye-witnesses assure us that he had ample feed on hand to keep one hundred of cattle the year round.

We might go on and enumerate many other points in which the siloing process has decidedly the advant- 
age over the method of field-curing fodder or haymaking; but it is hardly necessary. The points given in the preceding will convince any person open to conviction, of the superiority of the silo on stock or dairy farms. As we proceed with our discussion we shall have occasion to refer to several points in favor of silage as compared with dry feed, which have not already been touched upon. We shall now, first of all, however, proceed to explain the methods of building silos, and then discuss the subjects of making and feeding silage. 


\section{CHAPTER II.}

\section{HOW TO BUILD A SILO.}

Before taking up for consideration the more important types of silo construction, it will be well to explain briefly a few fundamental principles in regard to the building of silos which are common to all types of silo structures. When the farmer understands these principles thoroughly, he will be able to aroid serious mistakes in building his silo and will be less bound by specific directions, that may not always exactly suit his conditions, than would otherwise be the case. What is stated in the following in a few words is in many cases the result of dearly-bought experiences of pioneers in siloing; many points may seem self-evident now, which were not understood or appreciated until mistakes had been made and a full knowledge had been accumulated as to the conditions under which perfect silage can be secured.

\section{General Requirements for Silo Structures.}

- I. The silo must be air-tight. We have seen that the process of silage making is largely a series of fermentation processes. Bacteria (small plants or germs, which are found practically everywhere) pass into the silo with the corn or the siloed fodder, and, after a short time, begin to grow and multiply in it, favored by the presence of air and an abundance of feed materials in the fodder. The activity of the bacteria is soon discernible through the heating of the mass and the formation of acid in the fodder. The more air at the disposal of the bacteria, the further the fermentation processes will progress. If a supply of air is admitted to the silo from the outside, the bacteria will have a chance to continue to grow, and more fodder 
will therefore be wasted. If a large amount of air be admitted, as is usually the case with the top layer of silage, the fermentation processes will be more farreaching than is usually the case in the lower layers of the silo. Putrefactive bacteria will then continue the work of the acid-bacteria, and the result will be rotten silage. If 110 further supply of air is at hand, except what remains in the interstices between the siloed fodder, the bacteria will gradually die out, or only such forms will survive as are able to grow in the absence of air.

Another view of the cause of the changes occurring in siloed fodder has been put forward lately, viz., that these are due not to bacteria, but to "intramolecular respiration' in the plant tissue; that is, to a natural dying-off of the life substance of the plant cells. From a practical point of view it does not make any difference whether the one or the other explanation is correct. The facts are with us, that if much air is admitted into the silo, through cracks in the wall or through loose packing of the siloed mass, considerable losses of food substances will take place, first, because the processes of decomposition are then allowed to go on beyond the point necessary to bring about the changes by which the silage differs from green fodder, and second, because the decomposition will cause more. or less of the fodder to spoil and mold.

2. The silo must be deep. Depth is essential in building a silo, so as to have the siloed fodder under considerable pressure, which will cause it to pack well and leave as little air as possible in the interstices between the cut fodder, thus reducing the losses of food materials to a minimum. The early silos built in this country or abroad were at fault in this respect; they were shallow structures, not over I2-I5 ft. perhaps, and were longer than they were deep. Experience showed that it was necessary to weight heavily the siloed fodder placed in these silos, in order to avoid 
getting a large amount of moldy silage. In our modern silos no weighting is necessary, since the material placed in the silo is sufficiently heavy from the great depth of it to largely exclude the air in the siloed fodder and thus secure a good quality of silage. In case of deep silos the loss from spoiled silage on the top is smaller in proportion to the whole amount of silage stored; there is also less surface in proportion to the silage stored, hence a smaller loss occurs while the silage is being fed out, and since the silage is more closely packed, less air is admitted from the top. As the silage packs better in a deep silo than in a shallow one, the former kind of silos will hold more silage per cubic foot than the latter; this is plainly seen from the figures given in the table on p. 3I. Silos built during late years have generally been over thirty feet deep, and many are forty feet deep, or more.

3. The silo must have smooth, perpendicular walls, which will allow the mass to settle without forming cavities along the walls. In a deep silo the fodder will settle several feet during the first few days after filling. Any unevenness in the wall will prevent the mass from settling uniformly, and air spaces in the mass thus formed will cause the surrounding silage to spoil.

4. The walls of the silo must be rigid and very strong, so as not to spring when the siloed fodder settles. The lateral (outward) pressure of cut fodder corn when settling at the time of filling is considerable, and increases with the depth of the silage at the rate of about eleven pounds per square foot of depth. At a depth of 20 feet there is, therefore, an outward presssure of about 220 pounds per square foot; at 30 feet a pressure of 330 pounds, etc. In case of a I6-foot square silo where the sill is 30 feet below the top of the silage the side pressure on the lower foot of the wall would be about $16 \times 330$, or 5280 pounds.

It is because of this great pressure that it is so difficult to make large rectangular silos deep enough to be 
economical, and it is because the walls of rectangular silos always spring more or less under the pressure of the silage that this seldom keeps as well in them as it does in those whose walls cannot spring.

As the silage in the lower part of the silo continues to settle, the stronger outward pressure there spreads the walls more than higher up and the result is the wall may be actually forced away from the silage, so that air may enter from above; and even if this does not occur the pressure against the sides will be so much lessened above by the greater spreading below that if the walls are at all open, air will nore readily enter through them.

In the round wooden silos every board acts as a hoop and as the wood stetches but little lengthwise there can be but little spreading of sucl walls, and in the case of stave silos the iron hoops prevent any spreading, and it is on account of these facts that the round silo is rapidly replacing every other form.

After the silage has once settled, there is no lateral pressure in the silo; cases are on record where a filled silo has burned down to the ground with the silage remaining practically intact as a tall stack.

Other points of importance in silo building which do not apply to all kinds of silos, will be considered when we come to describe different kinds of silo structures. Several questions present themselves at this point for consideration, viz., how large a silo shall be built, where it is to be located, and what form of silo is preferable under different conditions?

\section{On the Size of Silo Required.}

In planning a silo the first point to be decided is how large it shall be made. We will suppose that a farmer has a herd of twenty-five cows, to which he wishes to feed silage during the winter season, say for I 80 clays. We note at this point that silage will not be likely to give best results with milch cows, or with 
any other class of farm animals, when it furnishes the entire portion of the dry matter of the feed ration. As a rule, it will not be well to feed over forty pounds of silage daily per head. If this quantity be fed daily, on an average for a season of i 80 days, we have for the twenty-five cows i 80,000 pounds, or ninety tons. On account of the fermentation processes taking place in the silo, we have seen that there is an unavoidable loss of food materials during the siloing period, amounting to, perhaps, io per cent. ; we must, therefore, put more than the quantity given into the silo. If ninety tons of silage is wanted, about one hundred tons of fodder corn must be placed in the silo; we figure, therefore, that we shall need about 4 tons of silage per head for the winter, but, perhaps, 5 tons per head would be a safer calculation, and provide for some increase in the size of the herd.

Coril silage will weigh from thirty pounds, or less, to toward fifty pounds per cubic foot, according to the depth in the silo from which it is taken, and the amount of moisture which it contains. We may take forty pounds as an average weight of a cubic foot of corn silage. One ton of silage will, accordingly, take up fifty cubic feet; and Ioo tons, 50oo cubic feet. If a rectangular one-hundrd-ton silo is to be built, say I 2 XI 4 feet, it must then have a height of 30 feet. If a square silo is wanted, it might be given dimensions I $2 \mathrm{XI}_{2} \mathrm{X} 35$ feet, or $\mathrm{I} 3 \mathrm{XI} 3 \mathrm{X} 30$ feet; if a circular silo the following dimensions will be about right ; diameter I 6 feet, height of silo 26 feet, etc. In the same way, a silo holding 200 tons of corn or clover silage may be built of the dimensions I $6 \times 24 \times 26$ feet, $20 \times 20 \times 25$ feet, or, if round, diameter, 20 feet, height 32 feet. etc.

Since the capacity of round silos is not as readily computed as in case of rectangular silos, we give below a table which shows at a glance the approximate number of tons of silage that a round silo, of a diam- 
eter from Io to 26 feet, and 20 to 32 feet deep, will hold.

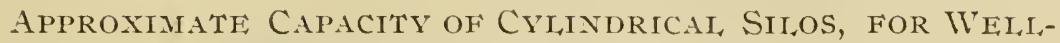
MATURED CORN SIIAGE, IN TONS.

\begin{tabular}{|c|c|c|c|c|c|c|c|c|c|c|c|c|c|}
\hline \multirow{2}{*}{$\begin{array}{c}\text { DEPTH } \\
\text { OF } \\
\text { SILO } \\
\text { FEET. }\end{array}$} & \multicolumn{13}{|c|}{ INSIDE DIAAIETER OF Silo, FEet. } \\
\hline & 10 & 12 & 14 & 15 & 16 & 18 & 20 & 21 & 22 & 23 & 24 & 25 & 26 \\
\hline $\begin{array}{l}20 \ldots \ldots \\
21 \ldots \ldots \\
22 \ldots \ldots \\
23 \ldots \ldots \\
24 \ldots \\
25 \ldots \ldots \\
26 \ldots \ldots \\
27 \ldots \ldots \\
28 \ldots \ldots \\
29 \ldots \ldots \\
30 \ldots \ldots \\
31 \ldots \ldots \\
32 \ldots \ldots \\
\end{array}$ & $\begin{array}{l}20 \\
28 \\
30 \\
32 \\
34 \\
36 \\
38 \\
40 \\
42 \\
45 \\
47 \\
49 \\
51\end{array}$ & $\begin{array}{l}35 \\
40 \\
43 \\
46 \\
49 \\
52 \\
55 \\
58 \\
61 \\
64 \\
68 \\
70 \\
73\end{array}$ & $\begin{array}{r}51 \\
55 \\
59 \\
62 \\
66 \\
70 \\
74 \\
78 \\
83 \\
88 \\
93 \\
96 \\
101\end{array}$ & $\begin{array}{r}59 \\
63 \\
67 \\
72 \\
76 \\
81 \\
85 \\
90 \\
95 \\
100 \\
105 \\
110 \\
115\end{array}$ & $\begin{array}{r}67 \\
72 \\
77 \\
82 \\
87 \\
90 \\
97 \\
103 \\
108 \\
114 \\
119 \\
125 \\
131\end{array}$ & $\begin{array}{r}85 \\
91 \\
97 \\
103 \\
110 \\
116 \\
123 \\
130 \\
137 \\
1+4 \\
151 \\
158 \\
160\end{array}$ & $\begin{array}{l}105 \\
112 \\
120 \\
129 \\
135 \\
143 \\
152 \\
160 \\
169 \\
175 \\
187 \\
195 \\
205\end{array}$ & $\begin{array}{l}115 \\
123 \\
132 \\
141 \\
149 \\
153 \\
168 \\
177 \\
186 \\
196 \\
206 \\
215 \\
226\end{array}$ & $\begin{array}{l}127 \\
135 \\
145 \\
154 \\
164 \\
173 \\
154 \\
114 \\
204 \\
215 \\
226 \\
236 \\
248\end{array}$ & $\begin{array}{l}138 \\
148 \\
158 \\
169 \\
179 \\
190 \\
201 \\
212 \\
223 \\
235 \\
247 \\
258 \\
271\end{array}$ & $\begin{array}{l}151 \\
161 \\
172 \\
184 \\
195 \\
206 \\
219 \\
231 \\
243 \\
265 \\
269 \\
262 \\
295\end{array}$ & $\begin{array}{l}163 \\
175 \\
187 \\
199 \\
212 \\
224 \\
237 \\
251 \\
264 \\
278 \\
292 \\
305 \\
320\end{array}$ & $\begin{array}{l}177 \\
159 \\
202 \\
216 \\
229 \\
242 \\
257 \\
271 \\
285 \\
300 \\
315 \\
330 \\
346\end{array}$ \\
\hline
\end{tabular}

The following table which las been reproduced from a trade publication shows at a glance how much silage is required to keep eight to forty-five cows for six months, feeding them 40 lbs. a day, and the dimensions of circular silos as well as the area of land required to furnish the different amounts of feed given, computed at 15 tons per acre. The amounts of silage giren in the table refer to the number of tons in the silo after all shrinkage has occurred; as the condition of the corn as placed in the silo differs considerably, these figures may vary in different years, or with different crops of corn, and should not be interpreted too strictly; the manner of filling the silo will also determine how much corn the silo will hold: if the silo is filled with well-matured corn, and after this has settled for a couple of days, filled up again, it will hold at least ten per cent more silage than when it is filled rapidly and not refilled after settling. To the person about to fill a silo for the first time, it is suggested that it requires 
a "good crop" to yield I 5 tons per acre, and as a "little too much is about right," be sure to plant enough to fill the silo full, being guided by the condition of soil, etc., under his control.

\begin{tabular}{|c|c|c|c|}
\hline Dimensions. & Capacity 'Tons. & $\begin{array}{l}\text { Acres to fill, } 15 \\
\text { Tons to Acre. }\end{array}$ & $\begin{array}{l}\text { Cows it will heep } \\
6 \text { months. } 401 \mathrm{bs} \text {. } \\
\text { feed per day. }\end{array}$ \\
\hline $10 \times 20$ & $2 S$ & 2 & S \\
\hline $12 \times 20$ & 40 & 3 & I I \\
\hline $12 \times 24$ & 49 & $32-5$ & 13 \\
\hline I $2 \times 2 S$ & 60 & 4 & 15 \\
\hline $14 \times 22$ & $6 I$ & $4 \mathrm{I}-2$ & 17 \\
\hline $14 \times 24$ & 67 & $42-3$ & 19 \\
\hline $14 \times 28$ & $s_{3}$ & $52-3$ & 22 \\
\hline $\mathrm{r} 4 \times 3^{\circ}$ & 93 & 6 & 23 \\
\hline $16 \times 24$ & 87 & $62-5$ & 24 \\
\hline $16 \times 26$ & 97 & 7 & 26 \\
\hline $16 \times 30$ & II 9 & S & 29 \\
\hline IS $\times 30$ & I $5 \mathrm{I}$ & I $1-5$ & 37 \\
\hline IS $\times 36$ & I So & I2. $I-3$ & 45 \\
\hline
\end{tabular}

\section{On the Form of Silos.}

The first kind of silos built, in this country or abroad, were simply holes or pits in the ground, into which the fodder was dumped, and the pit was then covered with a layer of dirt and, sometimes at least, weighted with planks and stones. Then, when it was found that a large proportion of the feed would spoil by this crude method, separate silo structures were built, first of stone, and later on, of wood, brick or cement. As previously stated, the first separate silos built were rectangular, shallow structures, with a door opening at one end. 'The silos of the French pioneer Siloist, Auguste Goffart, were about i 6 feet high and $40 \times$ I 6 feet at the bottom. Another French silo built about fifty years ago, was $206 \times 2 \mathrm{I} / 2$ feet, and 15 feet deep, holding nearly i 500 tons of silage. Silos of a similar type, but of smaller dimensions, were built in this country in the early stages of silo building. Experience had taught siloists that it was necessary to 
weight the fodder heavily in these silos, in order to avoid the spoiling of large quantities of silage. In Goffart's silos, boards were thus placed on top of the siloed fodder, and the mass was weighted at the rate of one hundred pounds per square foot.

It was found, however, after some time, that this heavy weighting could be dispensed with by naking the silos deep, and gradually the deep silos came more and more into use. These silos were first built in this country in the latter part of the eighties; at the present time none but silos at least twenty to twenty-four feet deep are built, no matter of what form or material they are made, and most silos built are at least twentyfour to thirty feet deep, or more.

Since I 892 the cylindrical form of silos has become more and more general. These silos have the advantage over all other kinds in point of cost and covenience, as well as quality of the silage obtained. We shall, later on, have an occasion to refer to the relative cost of the various forms of silos, and shall here only mention a few points in favor of the round silos.

I. Round silos can be built cheaper than square ones, because it takes less lumber per cubic foot capacity, and because lighter material may be used in their construction. The sills and studding here do no work except to support the roof, since the lining acts as a hoop to prevent spreading of the wall.

2. One of the essentials in silo building is that there shall be a minimum of surface and wall exposure of the silage, as both the cost and the danger from losses through spoiling are thereby reduced. The round silos are superior to all other forms in regard to this point, as will be readily seen from an example: A rectangular silo, $16 \times 32 \times 24$ feet, has the sanie number of square feet of wall surface as a square silo, 24x24 feet, and of the same depth, or as a circular silo 30 feet in diameter and of the same depth; but these silos will hold about the following quantities of silage: 
Rectangular silo, 246 tons; square silo, 276 tons; circular silo, 338 tons. Less lumber will, therefore, be needed to hold a certain quantity of silage in case of square silos than in case of rectangular ones, and less for cylindrical silos than for square ones, the cylindrical form being, therefore, the most economical of the three types.

3. Silage of all kinds will usually begin to spoil after a few days, if left exposed to the air; hence the necessity of considering the extent of surface exposure of silage in the silo while it is being fed out. In a deep silo there is less silage exposed in the surface layer in proportion to the contents than in shallow silos. Experience has taught us that if the silage is fed down at a rate slower than I.2 inches daily, molding is liable to set in. About two inches of the top layer of the silage should be fed out daily during cold weather in order to prevent the silage from spoiling; in warm weather about three inches must be taken off daily; if a deeper layer of silage can be fed off daily, there will be less waste of food materials; some farmers thus plan to feed off 5 or 6 inches of silage daily. The form of the silo must therefore be planned, according to the size of the herd, with special reference to this point. Professor King estimates that there should be a feeding surface in the silo of about five square feet per cow in the herd; a herd of thirty cows will then require I 50 square feet of feeding surface, or the inside diameter of the silo should be I 4 feet; for a herd of forty cows a silo with a diameter of 16 feet will be required; for fifty cows, a diameter of I 8 feet; for one hundred cows, a diameter of $25 \mathrm{I} / 4$ feet, etc.

He gives the following table showing the number of cows required to eat 1.2 to 2 inches of silage daily in silos 24 and 30 feet deep, assuming that they are fed 40 lbs. of silage daily for I 80 or 240 days : 
Relation of Horizontal Feeding Area and Number of Cows Kept, for Silos 24 and 30 Feet Deep.

\begin{tabular}{|c|c|c|c|c|c|c|c|c|}
\hline \multirow{4}{*}{$\begin{array}{c}\text { No. } \\
\text { of } \\
\text { Cows. }\end{array}$} & \multicolumn{4}{|c|}{ FEED FOR 240 DAYS. } & \multicolumn{4}{|c|}{ FEED FOR ISO DAYS. } \\
\hline & \multirow{2}{*}{\multicolumn{2}{|c|}{ 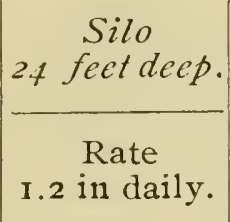 }} & \multirow{2}{*}{\multicolumn{2}{|c|}{$\frac{\begin{array}{c}\text { Silo } \\
\text { so fect deep. }\end{array}}{\text { Rate }}$}} & \multirow{2}{*}{\multicolumn{2}{|c|}{ 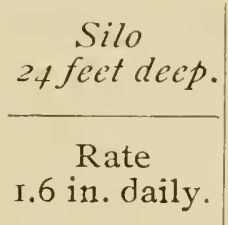 }} & \multirow{2}{*}{\multicolumn{2}{|c|}{$\begin{array}{c}\text { Silo } \\
\text { 3o fect deep } \\
\text { Rate } \\
2 \text { in. daily. }\end{array}$}} \\
\hline & & & & & & & & \\
\hline & Tons. & $\begin{array}{l}\text { Inside } \\
\text { diam. }\end{array}$ & Tons. & $\begin{array}{l}\text { Inside } \\
\text { diam. }\end{array}$ & Tons. & $\begin{array}{l}\text { Inside } \\
\text { diam. }\end{array}$ & Tons. & $\begin{array}{l}\text { Inside } \\
\text { diam. }\end{array}$ \\
\hline & & Feet. & & Feet. & & Feet. & & Feet. \\
\hline IO. . & 48 & 12 & $4 S$ & IO & 36 & 10 & 36 & 9 \\
\hline $15 \ldots$ & 72 & I 5 & 72 & 12 & 54 & 13 & 54 & I I \\
\hline $20 \ldots$ & 96 & 17 & 96 & 14 & 72 & 15 & 72 & I 2 \\
\hline $25 \ldots$ & I 20 & 19 & I 20 & 16 & 9o & I6 & 90 & 14 \\
\hline $30 \ldots$ & I 44 & $2 I$ & 144 & IS & 108 & IS & IOS & I 5 \\
\hline $35 \ldots$ & 168 & 22 & 168 & 19 & I 26 & I9 & I 26 & 16 \\
\hline $40 \ldots$ & 192 & 24 & 192 & 20 & I 44 & $2 I$ & I 44 & IS \\
\hline $45 \ldots$ & 216 & 26 & 216 & $2 \mathrm{I}$ & 162 & 22 & 162 & 19. \\
\hline $50 \ldots$ & 240 & 27 & 240 & 23 & ISo & 23 & I So & 20 \\
\hline $60 \ldots$ & $2 S S$ & 29 & $2 S S$ & 25 & 216 & 25 & 216 & $2 \mathrm{I}$ \\
\hline $70 \ldots$ & 336 & 32 & 336 & 27 & 252 & 27 & 252 & 23 \\
\hline So... & $3 \mathrm{~S}_{4}$ & 34 & 384 & 29 & $2 S S$ & 29 & $28 \delta$ & 25 \\
\hline $90 \ldots$ & 432 & 36 & 432 & 30 & 324 & $3 I$ & 324 & 26 \\
\hline IOO.. & 480 & $3^{S}$ & 480 & 32 & 360 & 33 & 360 & $2 S$ \\
\hline
\end{tabular}

In choosing diameters and depths for silos for particular herds, individual needs and conditions must decide which is best. It may be said, in general, that for the smaller sizes of silos the more shallow ones will be somewhat cheaper in construction and be more easily filled with small powers. For large herds the deeper types are best and cheapest.

One of the most common mistakes made in silo construction is that of making it too large in diameter for the amount of stock to be fed silage. Wherever silage heats and molds badly on or below the feeding surface 
heavy loss in feeding value is being sustained, and in such cases the herd should be increased so that the losses may be prevented by more rapid feeding. (King.)

\section{Location of the Silo.}

The location of the silo is a matter of great importance, which has to be decided upon at the start. The feeding of the silage is an every-day job during the whole winter and spring, and twice a day at that. Other things being equal, the nearest available place is therefore the best. The silo should be as handy to get at from the barn as possible. The condition of the ground must be considered. If the ground is dry outside the barn, the best plan to follow is to build the silo there, in connection with the barn, going four to six feet below the surface, and providing for doors opening directly into the barn. The bottom of the silo should be on or below the level where the cattle stand, and, if practicable, the silage should be moved out and placed before the corvs at a single handling. While it is important to have the silo near at hand, it should be so located, in case the silage is used for milk production, that silage odors do not penetrate the whole stable, at milking or at other times. Milk is very sensitive to odors, and unless care is taken to feed silage after milking, and to have pure air, free from silage odor, in the stable, at the time of milking, there will be a silage flavor to the milk. This will not be sufficiently pronounced to be noticed by most people, and some people cannot notice it at all; but when a person is suspicious, he can generally discover it. So far as is known this odor is not discernible in either butter or cheese made from silage-flavored milk, nor does it seem to affect the keeping qualities of the milk in any way.

\section{Different Types of Silo Structures.}

Silos may be built of rood, stone, brick or cement, 
or partly of one and partly of another of these materials. Wooden silos may be built of several layers of thin boards nailed to uprights, or of single planks (staves), or may be plastered inside. The material used will largely be determined by local conditions; where lumber is cheap, and stone high, wooden silos will generally be built; where the opposite is true, stone or brick silos will have the advantage in point of cheapness, while concrete silos are likely to be preferred where cobble-stones are at hand in abundance, and lumber or stone are hard to get at a reasonable cost. So far as the quality of the silage made in any of these kinds of silos is concerned, there is no difference when the silos are properly built. The longevity of stone and concrete silos is usually greater than that of wooden silos, since the latter are more easily attacked by the silage juices and are apt to decay in places after a number of years, unless special precautions are taken to preserve them. A well-built and well-cared-for wooden silo should, however, last almost indefinitely.

As regards the forn of the silo, it may be built in rectangular form, square, octagon or round. We have already seen that the most economical of these is ordinarily the round form, both because in such silos there is less wall space per cubic unit of capacity, and in case of wooden round silos, ligliter material can be used in their construction. The only place where silos of square or rectangular form are built now is inside of barns, where they fit in better than a round structure. We shall later on give directions for building silos inside of a barn, but shall now go over to a discussion of the various forms of round silos that are apt to be met with. More round wooden silos have been built during late years in this country than of all other kinds of silos combined, and this type of silos, either built of uprights lined inside and outside with two layers of half-inch boards, or of one thickness of 
staves, will doubtless be the main silo type of the future; hence we shall give full information as to their building, and shall then briefly speak of the other forms mentioned which may be considered preferable in exceptional cases.

\section{Round Wooden Silos.}

Round wooden silos were first described, and their use advocated, in Bulletin No. 28, issued by the Wisconsin Station in July, I89I, and hence have come to be known as "Wisconsin Silos." The first detailed and illustrated description of this type of silos was published in this bulletin; since that time it has been described in several bulletins and reports issued by the station mentioned, and in numerous publications from other experiment stations. All writers who have discussed the question of silo construction agree that this form of silos is admirable, and the best that can be put up where a durable, first-class silo of a moderate cost is wanted. This type, and the one to be described in the following, the stave silo, are practically the only kinds of wooden silos that have been built in this country during late years, except where unusual conditions have prevailed, that would make some other kind of silo structure preferable.

The following description of the Wisconsin silo is from the pen of Prof. King, the originator of this type of silos, as published in bulletin No. 83 of the Wisconsin Station (dated May, I900):

The Foundation.- There should be a good, substantial masonry foundation for all forms of wood silos, and the woodwork should everywhere be at least 12 inches above the earth, to prevent decay from dampness. There are few conditions where it will not be desirable to have the bottom of the silo 3 feet or more below the feeding floor of the stable, and this will require not less than 4 to 6 feet of stone, brick, or concrete wall. For a silo 30 feet deep the foundation wall 


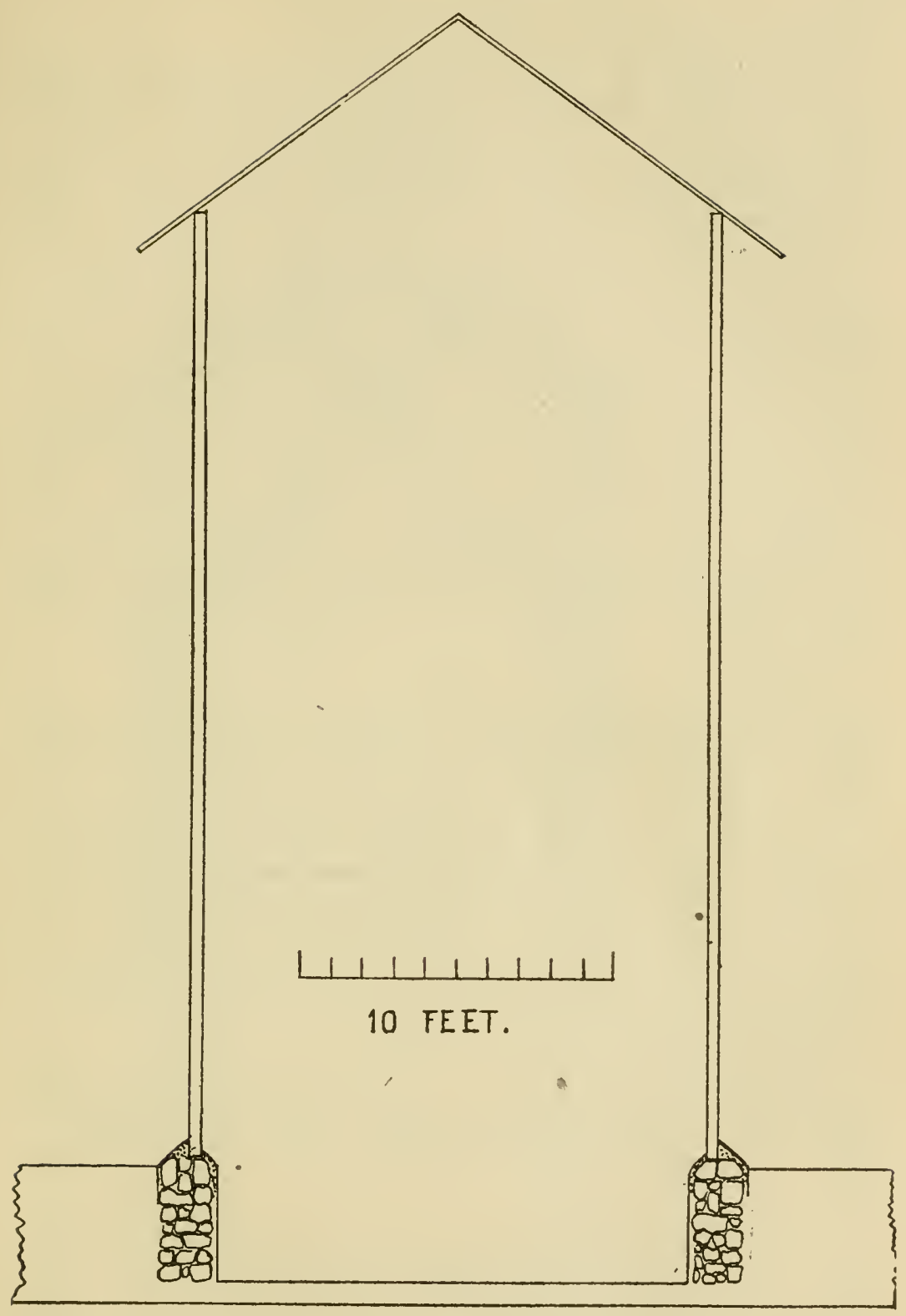

Fig. I. Showing method of placing all wood Silos on stone foundation, with pit dug out to increase depth. 
of stone should be $\mathrm{I} .5$ to 2 feet thick.

The inside of the foundation wall may be made flush with the woodwork above, or nearly so, as represented in Fig. I, or the building may stand in the ordinary way, flush with the outside of the stone wall, as represented in Fig. 2. In both cases the wall should be finished sloping as shown in the drawings.

- So far as the keeping of the silage is concerned it makes little difference which of these types of construction is adopted. The outward pressure on the silo wall is greater where the wall juts into the silo, but the wall is better protected against the weather. Where the projecting wall is outside, the silo has a greater capacity, but there is a strong tendency for the wall to crack and allow rain to penetrate it. Where this plan is followed it is important to finish the sloping surface with cement, or to shingle it, to keep out the water.

Bottom of the Silo.-After the silo has been completed the ground forming the bottom should be thoroughly tamped so as to be solid, and then covered with two or three inches of good concrete made of I of cement to 3 or 4 of sand and gravel. The amount of silage which will spoil on a hard clay floor will not be large, but enough to pay a good interest on the money invested in the cement floor. If the bottom of the silo is in dry sand or gravel the cement bottom is imperative to shut out the soil air.

Tying the Top of the Stone Wall. - In case the wood portion of the silo rises 24 or more feet above the stone work, and the diameter is more than 8 feet, it will be prudent to stay the top of the wall in some way.

If the woodwork rises from the outer edge of the wall, then building the wall up with cement so as to cover the sill and lining as represented in Figs. 3 and 4 will give the needed strength, because the woodwork will act as a hoop; but if the silo stands at the inner 


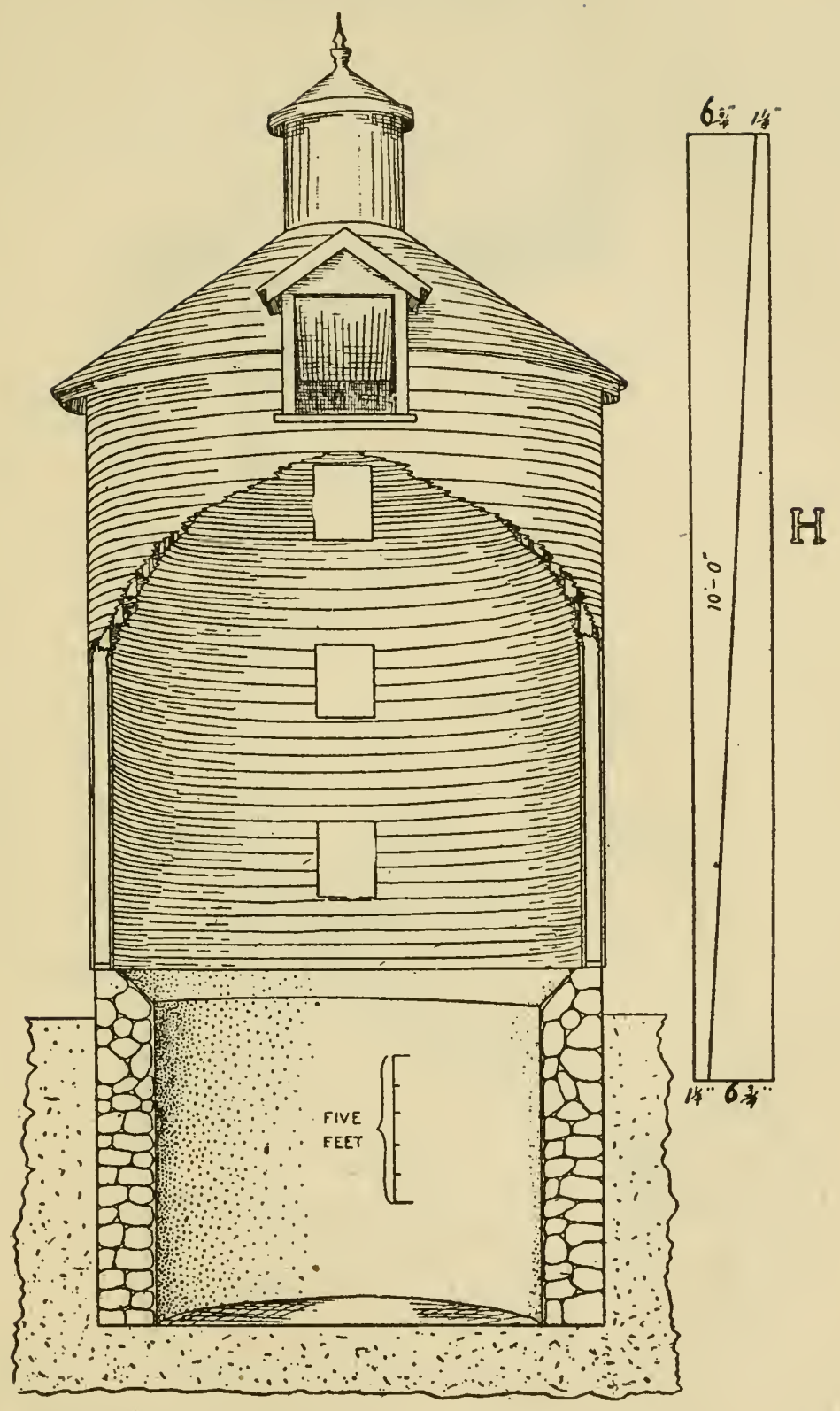

Fig. 2. Showing an all-wood round silo on stone foundation. $H$ represents a method of sawing boards for the conical roof. 

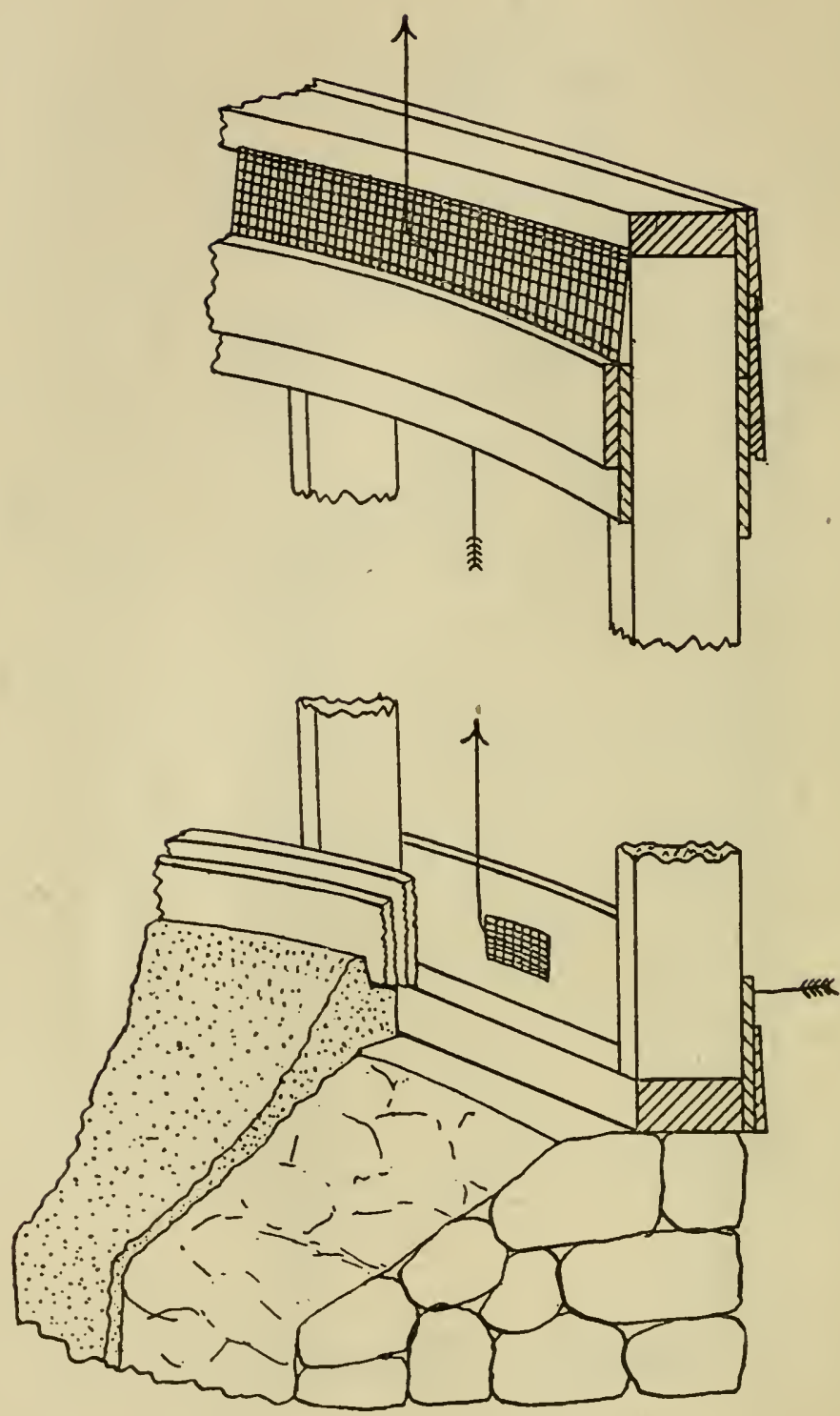

Fig. 3. Showing method of construction for wentilating the spaces between the studding in all-zeod and lathed and plastered silos. 
face of the wall, it will be best to lay pieces of iron rod in the wall near the top to act as a hoop.

Where the stone portion of the silo is high enough to need a door, it is best to leave enough wall between the top and the sill to allow a tie rod of iron to be bedded in this portion. So, too, the lower door in the

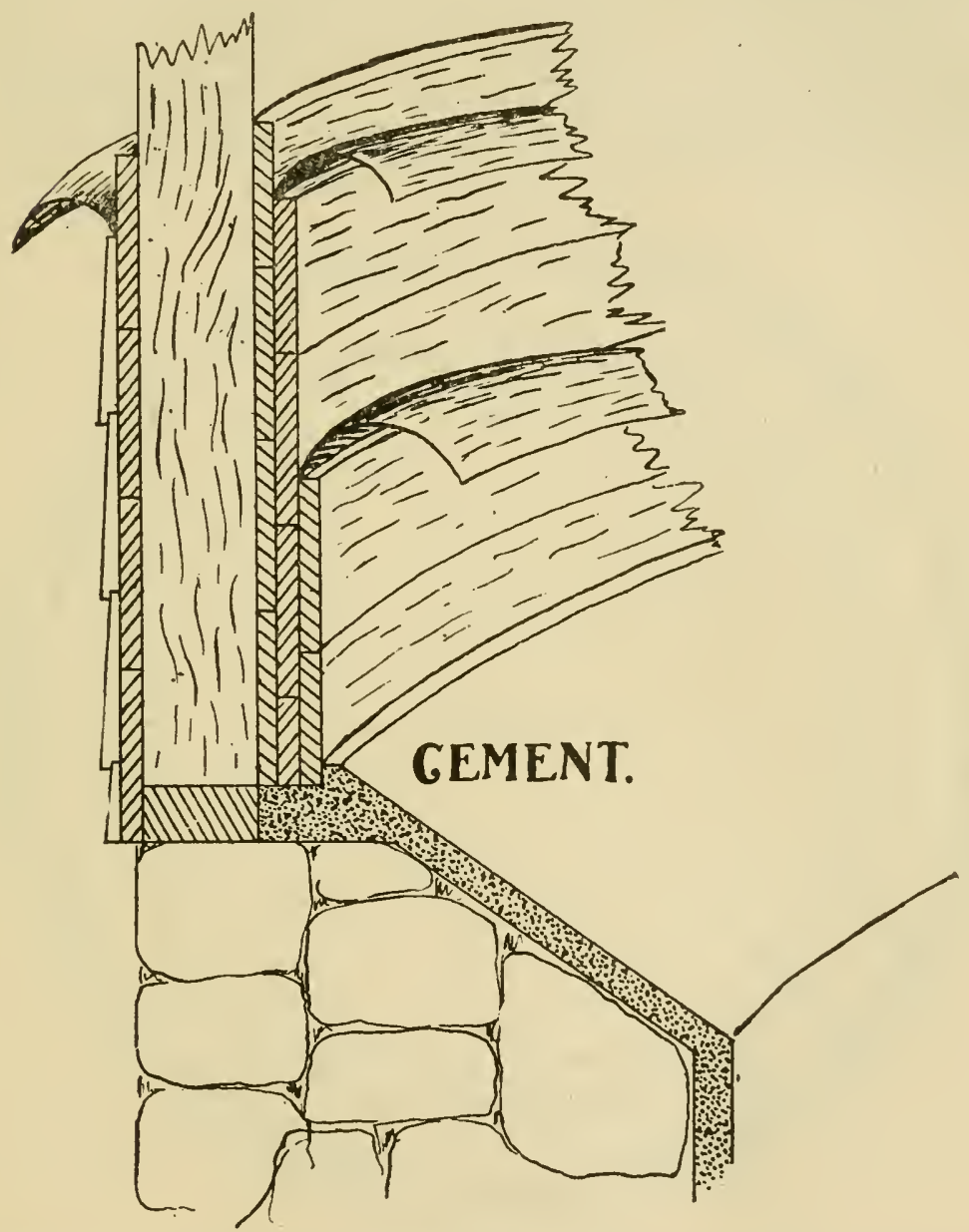

Fig. 4. Showing construction of all-wood silo, and connection with wall, flush with outside. 
woodwork of the silo should have a full foot in width below it of lining and siding uncut to act as a hoop, where the pressure is strongest.

Forming the Sill.-The sill in the all-wood silo may be made of a single $2 \mathrm{x}_{4}$ cut in 2 -foot lengths, with the ends beveled so that they may be toenailed together to form circle (Fig. 5).

Setting the Studding, - The studding of the allwood round silo need not be larger than $2 \mathrm{x}_{4}$ unless the diameter is to exceed 30 feet, but they should be set as close together as one foot from center to center, as represented in Fig. 6. This number of studs is not

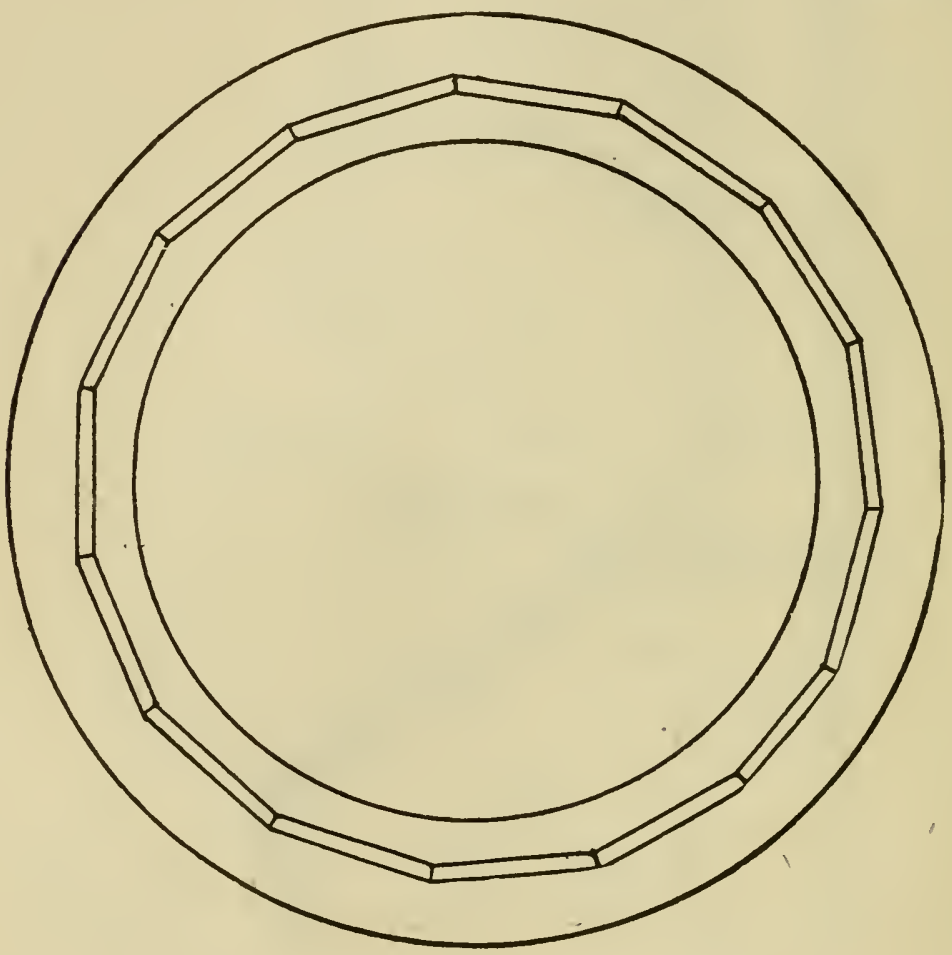

Fig. 5. Shou'ing method of making the sill of round wood Silos. 
required for strength but they are needed in order to bring the two layers of lining very close together, so as to press the paper closely and prevent air from entering where the paper laps.

Where studding longer than 20 feet are needed, short lengths may be lapped one foot and simply spiked together before they are set in place on the wall. This will be cheaper than to pay the higher price for long lengths. All studding should be given the exact length desired before putting them in place.

To stay the studding a post should be set in the

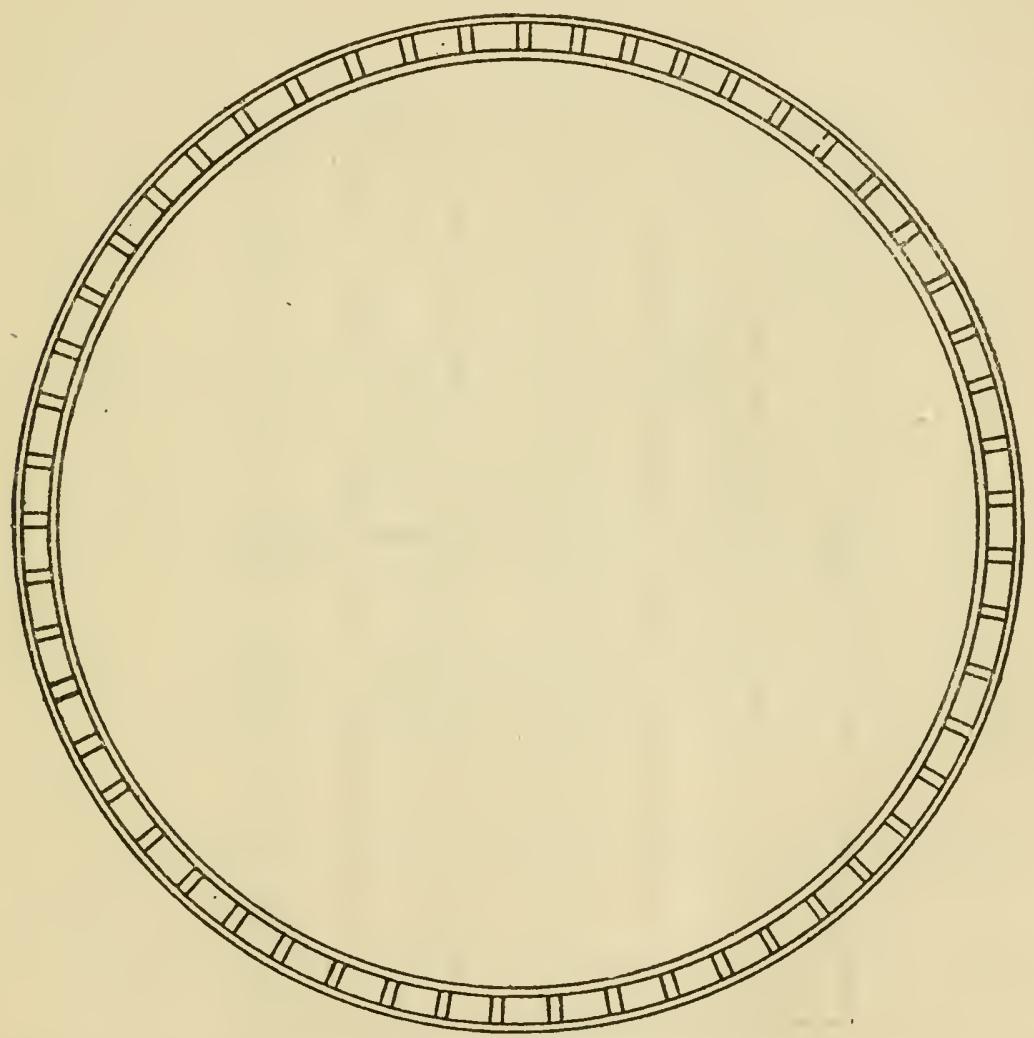

Fig. 6 Showing the plan of studding for the all-wood, bricklined or lathed and plastered silo. 
ground in the center of the silo long enough to reach about 5 feet above the sill, and to this stays may be nailed to hold in place the alternate studs until the lower 5 feet of outside sheeting has been put on. The studs should be set first at the angles formed in the
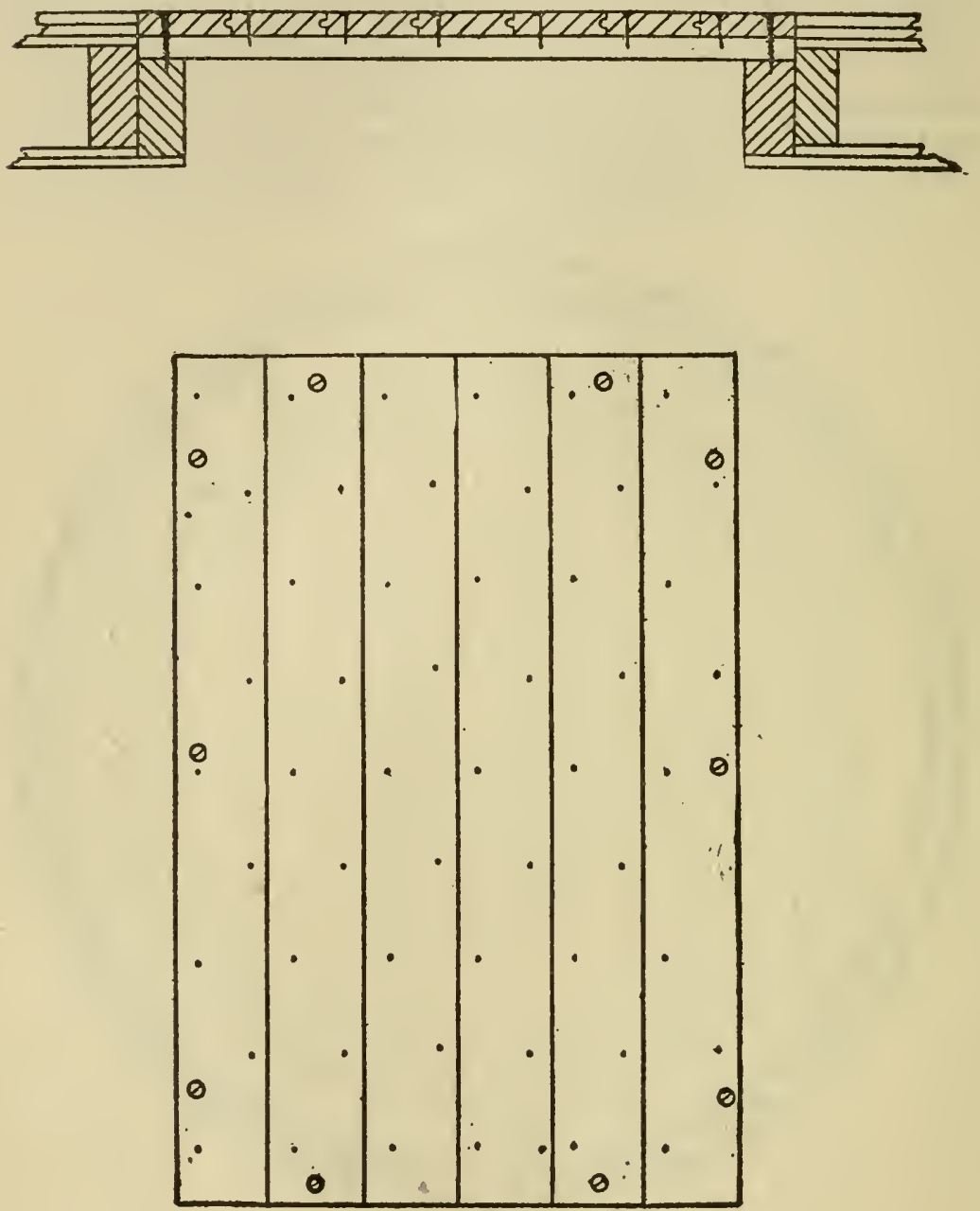

Fig. 7 . Showing the construction of the door for the all-wood silo. 
sill and carefully stayed and plumbed on the side toward the center. When a number of these have been set they should be tied together by bending a strip of half-inch sheeting around the outside as high up as a man can reach, taking care to plumb each stud on the side before nailing. When the alternate studs have been set in this way the balance may be placed and toe-11ailed to the sill and stayed to the rib, first plumbing them sideways and toward the center.

Setting Studding for Doors. - On the side of the silo where the doors are to be placed the studding should be set double and the distance apart to give the desired width. A stud should be set between the two door studs as though no door were to be there, and the doors cut out at the places desired afterwards. The construction of the door is represented in Fig. 7 .

Silo Sheeting and Siding.-The character of the siding and sheeting will vary considerably according to conditions, and the size of the silo.

Where the diameter of the silo is less than I 8 feet inside and not much attention need be paid to frost, a single layer of beveled siding, rabbetted on the inside of the thick edge deep enough to receive the thin edge of the board below, will be all that is absolutely necessary on the outside for strength and protection against weather. This statement is made on the supposition that the lining is made of two layers of fencing split in two, the three layers constituting the hoops.

If the silo is larger than 18 feet inside diameter, there should be a layer of haif-inch sheeting outside, under the siding.

If basswood is used for siding, care should be taken to paint it at once, otherwise it will warp badly if it gets wet before painting.

In applying the sheeting begin at the bottom, carrying the work upward until staging is needed, following this at once with the siding. Two 8-penny 
nails should be used in each board in every stud, and to prevent the walls from getting "out of round" the succeeding courses of boards should begin on the next stud, thus making the ends of the boards break joints.

When the stagings are put up, new stays should be tacked to the studs above, taking care to plumb each one from side to side; the siding itself will bring them into place and keep them plumb the other way, if care is taken to start new courses as described above.

Forming the Plate.-When the last staging is up

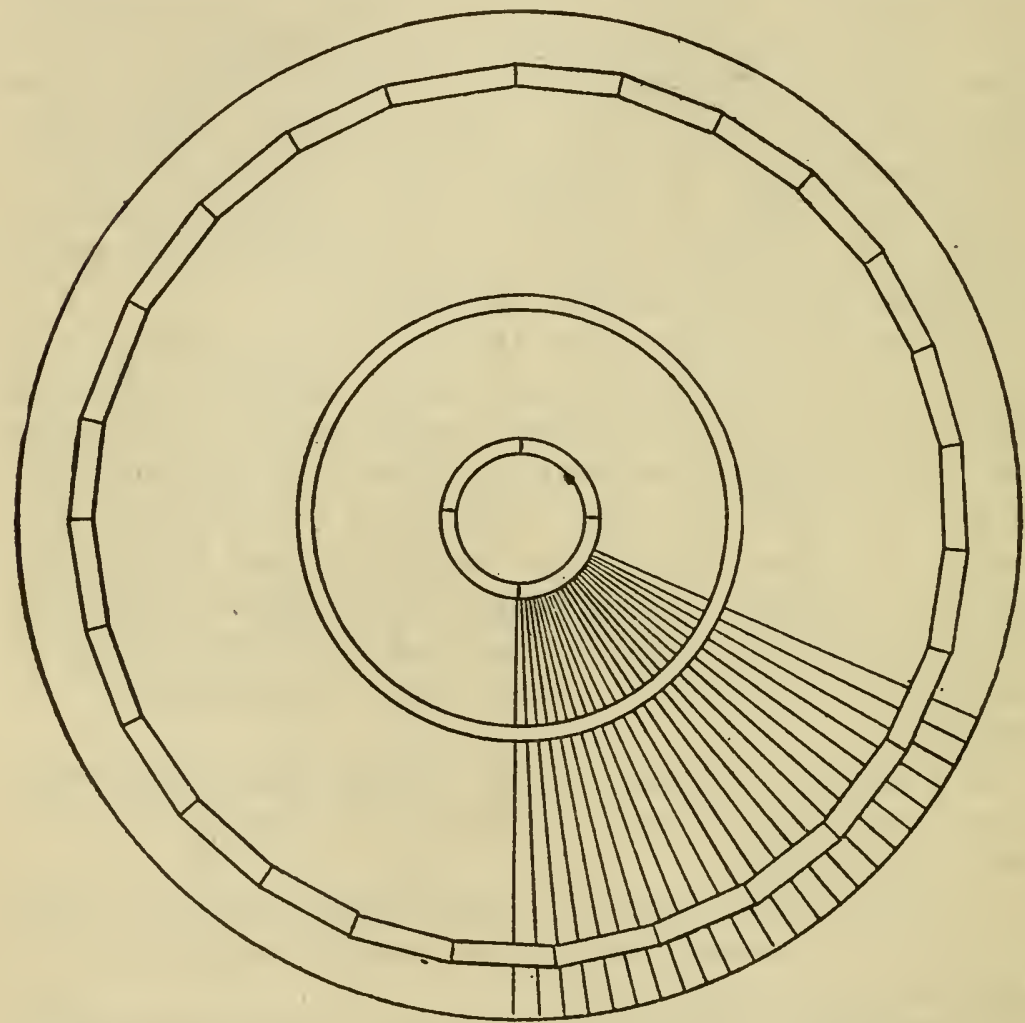

Fig. 8. Showin construction of conical roof of round silo, where rafters are not used. The outer cirele is the lower edge of the roof. 
the plate should be formed by spiking $2 \times 4$ 's cut in two-foot lengths, in the manner of sill, and as represented in Fig. 8, down upon the tops of the studs, using two courses, making the second break joints with the first.

The Lining of the Wooden Silo.-There are several ways of making a good lining for the all-wood round silo, but whichever method is adopted it must be kept in mind that there are two very important ends to be secured with a certainty. These are (I) a lining which shall be and remain strictly, air-tight, (2) a lining which will be reasonably permanent.

All Wood Lining of 4-inch Flooring.-If one is willing to permit a loss of Io to I 2 per cent. of the silage by heating, then a lining of tongued and grooved ordinary 4 -inch white pine flooring may be made in the manner represented in Fig. 9, where the flooring runs up and down. When this lumber is put on in the seasoned condition a single layer would make tighter walls than can be secured with the stave silo where the staves are neither beveled nor tongued and grooved.

In the silos smaller than i 8 feet inside diameter the two layers of boards outside will give the needed strength, but when the silo is larger than this and deep, there would be needed a layer of the split fencing on the inside for strength; and if in addition to this there is added a layer of 3-ply Giant P. and B. paper a lining of very superior quality would be thus secured.

Lining of Half-inch Boards and Paper-Where paper is used to make the joints between boards airtight, as represented in Fig. 4, it is extremely important that a quality which will not decay, and which is both acid- and water-proof be used. A paper which is not acid- and water-proof will disintegrate at the joints in a very short time, and thus leave the lining very defective.

The best paper for silo purposes with which we are 
acquainted is a 3 -ply Giant P. and B. brand manufactured by the Standard Paint Co., of Chicago and New York. It is thick, strong, and acid-and water-proof. A silo lining with two thicknesses of good fencing

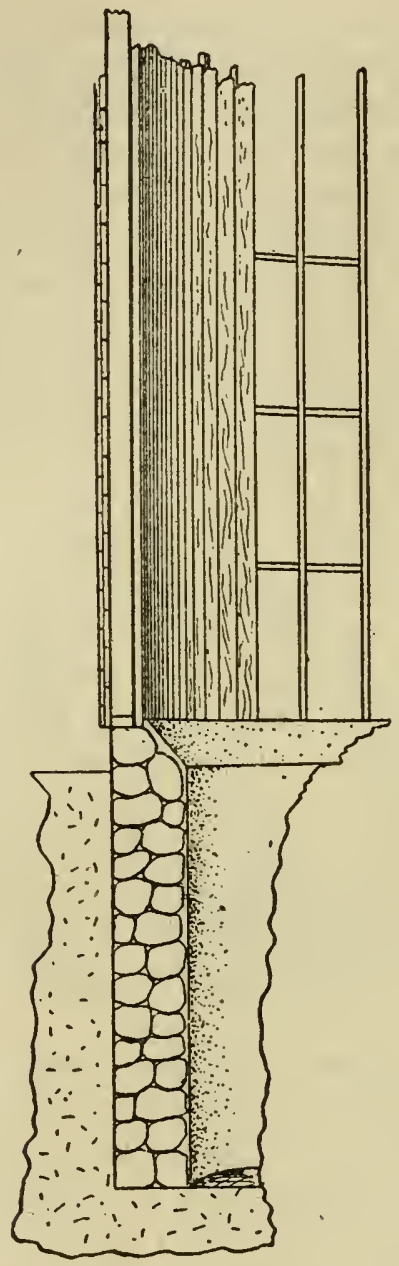

Fig. 9. Showing the construction of the all-wood round silo where the lining is made of ordinary four-inch flooring running up and down, and nailed to girts cut in between the studding every four fect. 
having only small knots, and these thoroughly sound and not black, will make an excellent lining. Great care should be taken to have the two layers of boards break joints at their centers, and the paper should lap not less than 8 to $\mathrm{I} 2$ inches.

The great danger with this type of lining will be that the boards may not press the two layers of paper together close enough but that some air may rise between the two sheets where they overlap, and thus gain access to the silage. It would be an excellent precaution to take to tack down closely with small carpet tacks the edges of the paper where they overlap, and if this is done a lap of 4 inches will be sufficient.

The first layer of lining should be put on with 8-penny nails, two in each board and stud, and the second or inner layer with ro-penny nails, the fundamental object being to draw the two layers of boards as closely together as possible.

Such a lining as this will be very durable because the paper will keep all the lumber dry except the inner layer of half-inch boards, and this will be kept wet by the paper and silage until empty, and then the small thickness of wood will dry too quickly to permit rotting to set in.

A still more substantial lining of the same type may be secured by using two layers of paper between three layers of boards, as represented in Fig. 4, and if the climate is not extremely severe, or if the silo is only to be fed from in the summer; it would be better to do away with the layer of sheeting and paper outside, putting on the inside, thus securing two layers of paper and three layers of boards for the lining with the equivalent of only 2 inches of lumber.

\section{The Silo Roof.}

The roof of cylindrical silos may be made in several ways, but the simplest type of construction and the 
one requiring the least amount of material is that represented in Figs. 7 and 8 , and which is the cone.

If the silo is not larger than i 5 feet inside diameter 110 rafters need be used, and only a single circle like that in the center of Fig. 8, this is made of 2 -inch stuff cut in sections in the form of a circle and two layers spiked together, breaking joints.

The roof boards are put on by nailing them to the inner circle and to the plate, as shown in the drawing, the boards having been sawed diagonally as represented at $\mathrm{H}$, Fig. 2, making the wide and narrow ends the same relative widths as the circumferences of the outer edge of the roof and of the inner circle.

If the silo has an inside diameter exceeding i 5 feet it will be necessary to use two or three hoops according to diameter. When the diameter is greater than 25 feet it will usually be best to use rafters and headers cut in for circles 4 feet apart to nail the roof boards to, which are cut as represented at H, Fig. 2.

The conical roof may be covered with ordinary shingles, splitting those wider than 8 inches. By laying the butts of the shingles $1 / 8$ to $1 / 4$ of an inch apart it is not necessary to taper any of the shingles except a few courses near the peak of the roof.

In laying the shingles to a true circle, and with the right exposure to the weather, a good method is to use a strip of wood as a radius which works on a center set at the peak of the roof and provided with a nail or pencil to make a mark on the shingle where the butts of the next course are to come. The radius may be bored with a series of holes the right distance apart to slip over the center pivot, or the nail may be drawn and reset as desired. Some carpenters file a notch in the shingling hatchet, and use this to bring the shingle to place.

\section{Ventilation of the Silo.}

Every silo which has a roof should be provided with 
ample ventilation to keep the under side of the roof dry, and in the case of wood silos, to prevent the walls and lining from rotting. One of the most serious mistakes in the early construction of wood silos was the making of the walls with dead-air spaces, which, on account of dampness from the silage, lead to rapid "dry rot" of the lining.

In the rood silo and in the brick lined silo it is inportant to provide ample ventilation for the spaces between the studs, as well as for the roof and the inside of the silo, and a good method of doing this is represented in Fig. 3, where the lower portion represents the sill and the upper the plate of the silo. Between each pair of stucs where needed a I $1 / 4$-inch auger hole to admit air is bored through the siding and sheeting and covered with a piece of wire netting to keep out mice and rats. At the top of the silo on the inside the lining is only covered to within two inches of the plate and this space is covered with wire netting to prevent silage from being thrown over when filling. This arrangement permits dry air from outside to enter at the bottom between each pair of studs and to pass up and into the silo, thus keeping the lining and studding dry and at the same time drying the under side of the roof and the inside of the lining as fast as exposed. In those cases where the sill is made of $2 x_{4}$ 's cut in 2 -foot lengths there will be space enough left between the curved edge of the siding and sheeting and the sill for air to enter so that no holes need be bored as described above and represented in Fig. 3. The openings at the plate should always be provided and the silo should have some sort of ventilator in the roof. This ventilator may take the form of a cupola to serve for an ornament as well, or it may be a simple galvanized iron pipe 12 to 24 inches in diameter, rising a font or two through the peak of the roof. 


\section{Painting the Silo Lining.}

It is impossible to so paint a wood lining that it will not become wholly or partly saturated with the silage juices. This being true, when the lining is again exposed when feeding the silage out, the paint greatly retards the drying of the wood work and the result is decay sets in, favored by the prolonged dampness. For this reason it is best to leave a wood lining naked or to use some antiseptic which does not form a waterproof coat.

The cost of such a silo as that described in the foregoing pages, is estimated by Prof. King at about 12.75 cents per square foot of outside surface, when the lining consists of two layers of half-inch split fencing, with a 3-ply Giant P. \& B. paper between, and with one layer of split fencing outside, covered with rabbeted house siding. If built inside of the barn, without a roof and not painted, the cost would be reduced 3 cents per square foot, or more. Silos of this type, 30 feet deep, built outside, provided with a roof and including 6 feet of foundation, are stated to cost as follows: I 3 feet inside diameter (So tons capacity), \$183.00; 15 feet diameter ( 105 tons capacity), \$2 I 1.00; 2 I feet diameter (206 tons capacity), \$298.00; and 25 feet diameter (300 tons capacity), $\$ 358.00$.

Complete specifications and building plans for a $300-$ ton silo, of the kind described in the preceding pages, are given in Prof. Woll's Book on Silage (Rand, McNally \& Co., Chicago, publishers). The dimensions of this silo are: Diameter 26 feet, height 30 feet.

According to our present knowledge this form of silo is most likely the best that can be built; it is a somewhat complicated structure, calls for more time and skill for its construction, and costs more than other kinds of wooden circular silos, especially more than the stave silo soon to be described; but once built, it needs but little attention, and it is durable 
and economical; being practically air-tight, the losses of food materials in the siloed fodder are reduced to a minimum.

\section{Modifications of the Wisconsin Silo.}

Several modifications of the Wisconsin silo have been proposed and have given good satisfaction; one is described by Prof. Plumb in Purdue Experiment Station Bulletin No. 9I, as follows:

The studs are is inches apart, and for about half way up there are three layers of sheeting against the studs with tarred paper between. The upper half of the studs has but two layers of sheeting. The sheeting was made by taking $2 \times 6$-inch white pine planks and sawing to make four boards. The silo rests on a stone wall 18 inches deep and 16 inches wide. It is 30 feet high, i 8 feet 4 inches inside diameter, and holds about $\mathrm{I}_{50}$ tons. An inexpensive but durable roof was placed upon it. The cost of this structure is as follows: As the work was all done by the regular farm help at odd hours, the item of labor is given at estimated cost: Studding, \$1 3.03: sheeting, $\$ 63.00$; 5 rolls paper, $\$ 6.25$; nails, $\$ 2.40$; cement for wall, $\$ 2.40$; labor, \$20.00; total, \$107.08. The owner of the silo was so pleased with the service this one had rendered since its construction, that he built another like it during the summer of 1902 . This silo is connected by a covered passage and chute with the feeding floor of the cattle barn.

The construction of this type of silo calls for as much care in putting on sheeting, making doors and keeping out the air at these places and at the foundation, as is required with the more expensive form previously described. The need for outer siding will depend in a large measure on circumstances. The farmer building the silo (living in Central Indiana) bas had no trouble with his silage freezing. In Northern Indiana the siding would naturally be more 
necessary than in the southern part of this state, but generally speaking, siding is not necessary, although it does materially add to the attractiveness of the silo.

\section{Plastered Round Wooden Silos.}

Plastered round wooden silos have met with favor among farmers who have tried them, and are preferred by many for either the original or the modified Wisconsin silo, on account of their ease of construction and their durability. In the experience of $\mathrm{H}$. B. Gurler, a well known Illinois dairyman, who has built several silos on his farm in the course of the last dozen years, the walls of plastered silos keep perfectly and

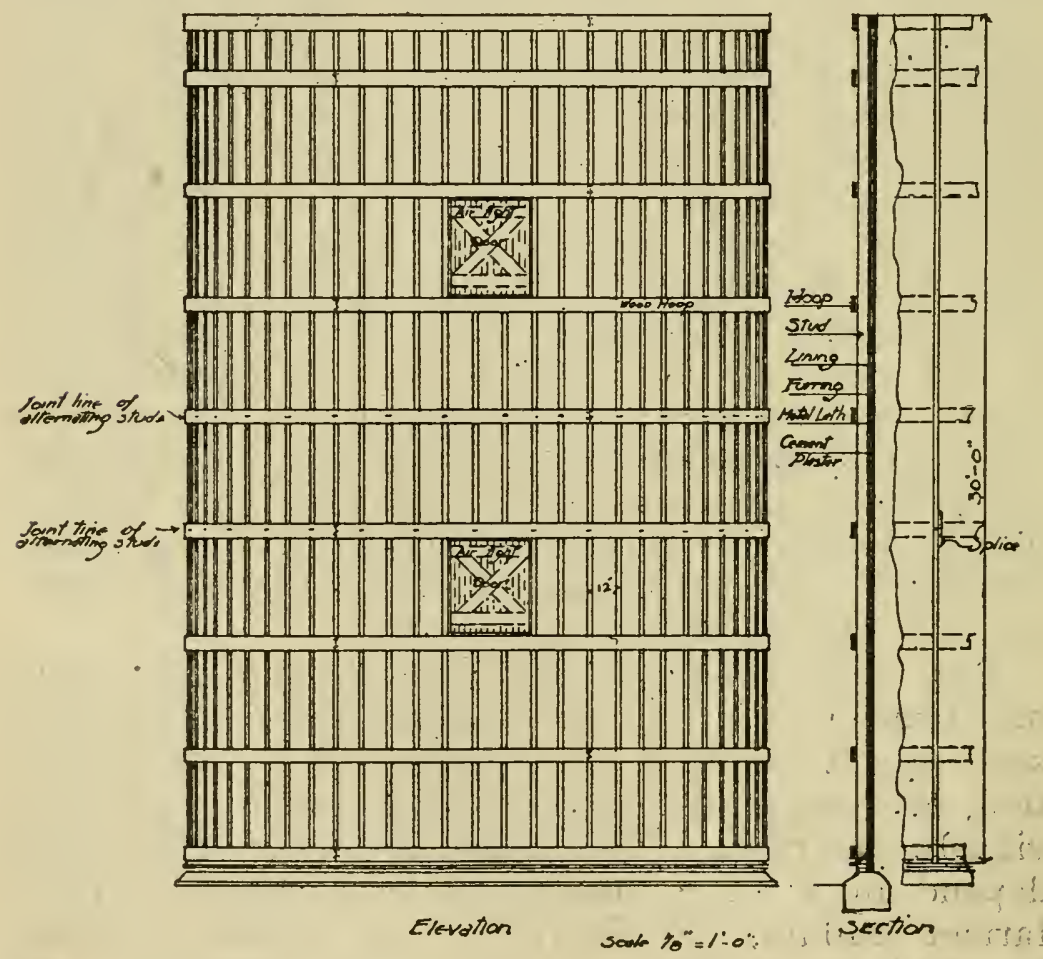

Fig. 912. Elevation and section of plastered round wooden silo, 
there is no waste from moldy silage along the wall; neither is there any difficulty about cracking of the plaster, if this is put on properly and a good quality of cement is used. Gurler described the construction of his plastered silo in a recent number of Breeder's Gazette, accompanying his description with building plans of his silo. We have reproduced the latter, changed and improved in some points of minor importance, and give below a brief description of the method of building silos of this type. (See Figs. $91 / 2$ and ro.)

The foundation may be made of stone, brick or cement, and is carried to the proper distance above ground. Sills composed of pieces of $2 \times 4$, two feet long, beveled at the ends so as to be toe-nailed togeth-

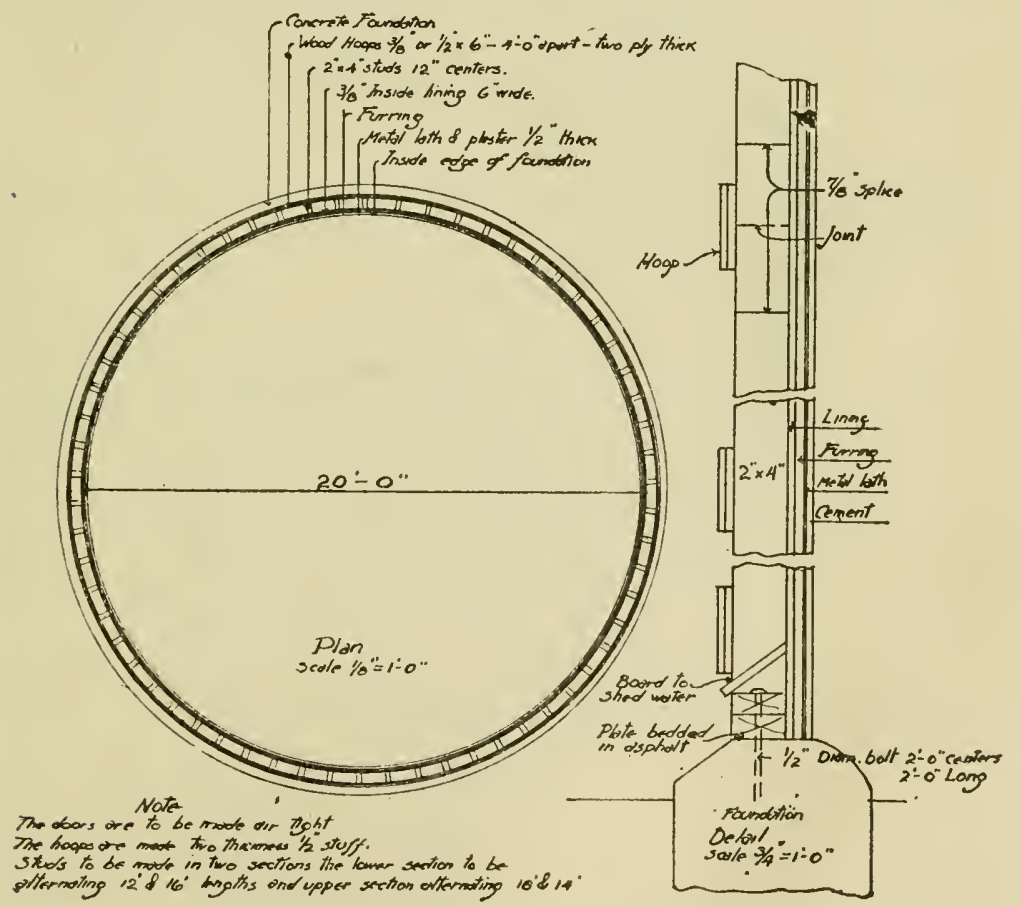

Fig. xo. Foundation plan and section of plastered round zooden silo. 
er to form a circle of the same diameter as the interior diameter of the silo, are placed on the foundation bedded in asphalt or cement mortar, and on this the studding is erected, using two by fours, placed 15 or I 6 inches apart. Inside sheeting was secured by having 6 inch fencing re-sawed, making the material a little less than $1 / 2$ inch thick. On this was nailed laths made from the same material, the laths being made with beveled edges so that when nailed onto the sheeting horizontally, the same way as the sheeting is put on, there are dove-tailed joints between the laths, to receive the cement, preventing its loosening until it is broken. The patent grooved laths might be used, but they cannot be sprung to a twenty-foot circle. Better than either kind of wooden laths, however, is wire netting or metal lath of one form or another, such as is now generally used in outside plastering of houses, nailed on strips of IX2's which are placed I 5 inches apart, and nailed onto the studding through the sheeting. Metal lath will not take up moisture from the silage juices, and thus expand and possibly cause the plaster to crack, as would be likely to occur in case of wooden laths. For outside sheeting similar material as that used for inside sheeting may be used. If built inside of a barn or in a sheltered place, no outside sheeting would be required, although it would add greatly to the looks of the silo. Not being certain that the inside sheeting, laths and cement offered sufficient resistance to the outward pressure in the silo, Mr. Gurler put on wooden hoops outside of the studding, of the same material as for the inside sheeting, putting it on double thickness and breaking joints. The silo described, which would hold 250-300 tons, cost $\$ 300$, without a ronf. Mr. Gurler considers this silo the best that can be built, and estimates that it will last for at least fifty years, if given a wash of cemerit every three years and if any cracks that may start be filled before the silo is filled again. 


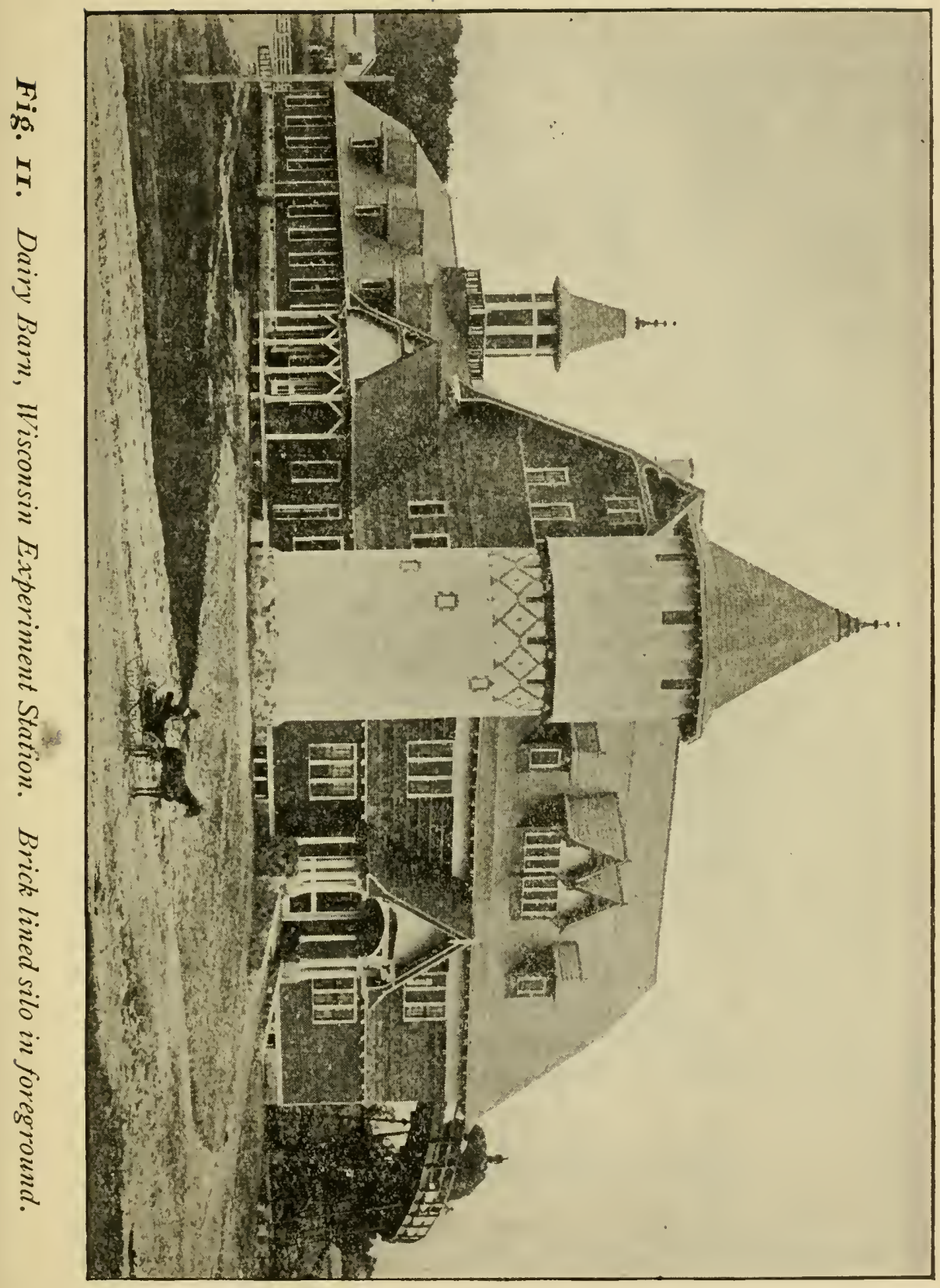




\section{Brick-Lined Silos.}

As an illustration of silos of this type we give below a description of the silo built in connection with the Dairy Barn of the Wisconsin Experiment Station: the accompanying figures, II and I2, will show the exterior appearance of the barn and silo, and a plan of the eastern half of the first floor of this barn.

The silo is circular in form, 18 feet inside diameter and 33 feet deep. It is a frame structure lined inside and outside with brick. On $2 \times 6$ inch uprights, two wrappings of $3 / 8$ inch stuff, 6 inches wide, are put, breaking joints, with no paper between. Brick is laid tight against this lining, and on the brick surface is a heavy coating of Portland cement ( I part cement, I part sand). On the outside brick is laid up against the lining with a small open space between (about $\mathrm{r} / 2$ inch). The silo is filled from the third floor of the barn, the loads of corn being hauled directly on to this floor over the trestle shown to the right in Fig. I I, and there run through the feed cutter. When the silage is taken out for feeding, it falls through a box chute to the main floor where it is received into a truck (Fig. 30) in which it is conveyed to the mangers of the animals.

An illustration and description of the original round silo, with a capacity of 90 tons, built at the same Station in I89I are given in Prof. Woll's Book on Silage, where descriptions and illustrations of a number of other first-class round wooden silos will also be found, like those constructed at the Experiment Stations in New Jersey, Missouri, and South Dakota.

\section{Stave Silos.}

The stave silo is the simplest type of separate silo buildings, and partly for this reason, partly on account of its cheapness of construction, more silos of this 
PIAN OF WIS, STA. DAIRY BARN.

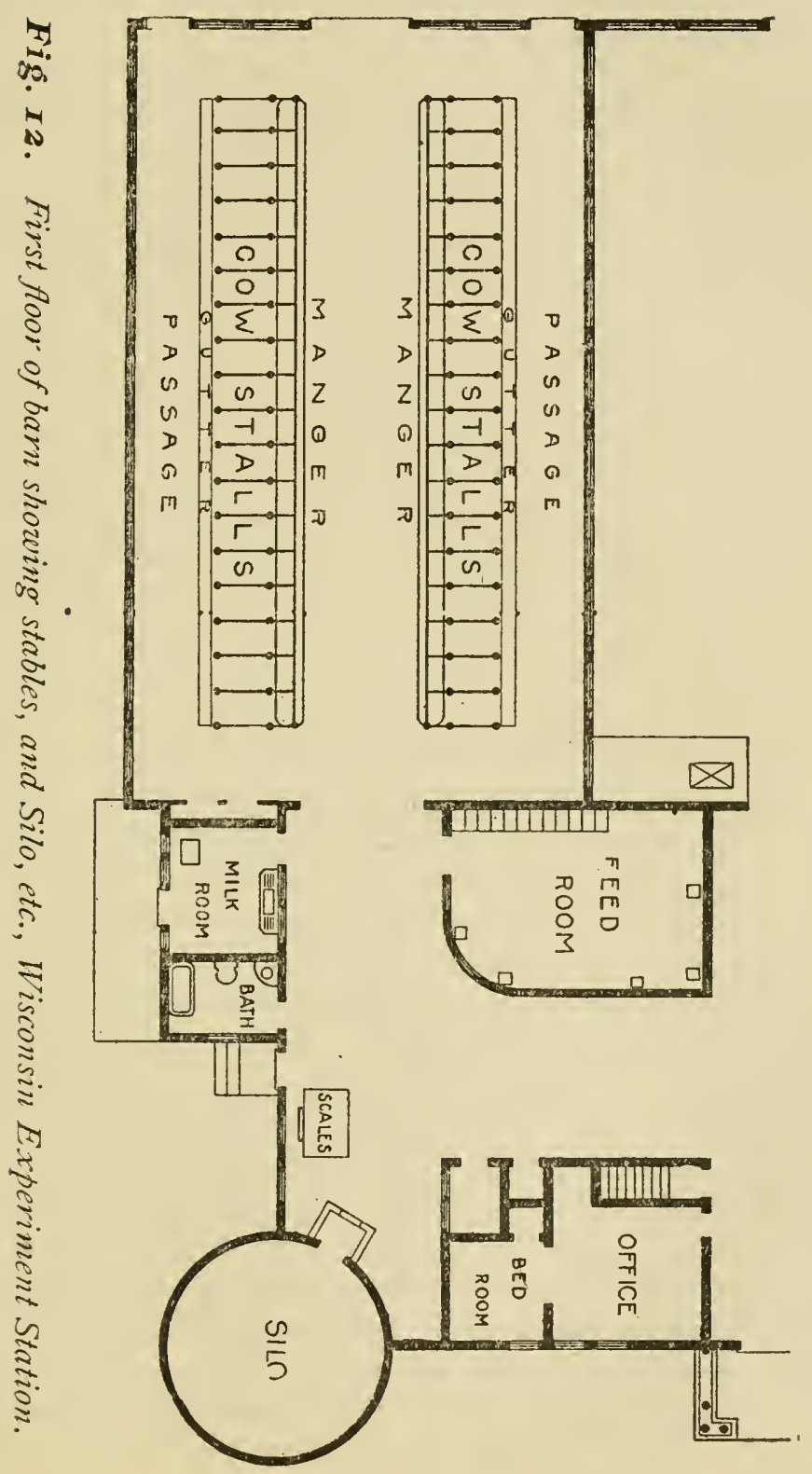


kind have been built during the past few years than any other silo type.

Since their first introduction Stave Silos have been favorably mentioned by most writers on agricultural topics, as well as by experiment station men. In a recent bulletin from Cornell Experiment Station, we find the stare silo spoken of as "the most practical and successful silo which can be constructed" ; and the Ottawa Experiment Station is on record for the following statement in regard to the stare silo: "From extensive observation and study of silos and silo construction, and from experience here with a number of different silos, it would appear that the stave silo is the form of cheap silos that for various reasons is most worthy of recommendation. It combines simplicity and cheapness of construction with the requisite conditions to preserve the silage in the very best condition for feeding.'

Stave silos are, generally speaking, similar to large railroad or fermentation tanks, and to make satisfactory silos should be built as well as a No. I water tank. The first stare silos were built in this country in the beginning of the nineties; they soon found some enthusiastic friends, while most people, including nearly all writers and lecturers on silo construction, were inclined to be skeptical as to their practicability. It was objected that the staves would expand so as to burst the hoops when the silo was filled with green fodder; that they would slirink after having been left empty during the summer months, so that the silo would fall to pieces, or at least so that it could not again be made air-tight; and finally, that the silage would freeze in such silos, and its feeding value thereby greatly lowered. In addition to this, it was claimed that a substantial stave silo would cost as much as a first-class ordinary all-wood silo of the same capacity, which would not have the objectionable features of the former. 
In spite of these objections the stave silo has, however, gradually gained ground, until of late years it has quite generally been adopted in preference to other kinds of silos, particularly in the Eastern and Central states. This being a fact, it follows that the objections previously made to the stave silos, can not be valid, that the staves do not swell so as to burst the hoops, or shrink so as to cause the silo to fall to pieces, or becomle leaky. As regards the danger from freezing of the silage, the criticisms of the stave silo are in order, as silage in outdoor stave silos will be likely to freeze in cold weather, in any of the Northern states or Canada; but, according to the testimony of farmers who have had experience with frozen silage, this is more an inconvenience than a loss. The freezing does not injure the feeding value of the silage, or its palatability. When the silage is thawed out it is as good as ever, and eaten by cattle with a relish.

\section{Why Stave Silos have Become Numerous.}

The main reasons why stave silos have been preferred by a majority of farmers during late years are that they can be put up asily, quickly, and cheaply, and the expense for a small silo of this kind is conlparatively small. Many a farmer has built a stave silo who could not afford to build a high-priced silo, and others have preferred to build two small silos for one large one, or a small one in addition to an old, larger one that they may already have. Manufacturing firms have, furthermore, made a specialty of stavesilo construction, and pushed the sale of such silos through advertisements and neat circulars. Having made a special business of the building of stave silos, and having had several years' experience as to the requirements and precautions to be observed in building such silos, these firms furnish silos complete with all necessary fixtures, that are greatly superior to any 
which a farmer would be apt to build according to more or less incomplete directions.

It follows that the stave silos sent out by manufacturing firms will generally be more expensive than such as a farmer can build himself, because they are built better. It does not pay to build a poor silo, however, except to bridge over an emergency. Poor, cheap silos are a constant source of annoyance, expense and trouble, whether built square, rectangular or round. The cheap silos described in other places of this book have not been given for the purpose of encouraging the building of such silos, but rather to show that if a farmer cannot afford to build a permanent, good silo, he is not necessarily barred from the advantage of having silage for his stock, since a temporary silo may be built at a small cash outlay.

We can therefore consistently recommend that parties intending to build stave silos patronize the manufacturers who have made silo construction a special business. These firms furnish all necessary silo fittings, with complete directions for putting up the silos, and, if desired, also skilled help to superintend their building. Perhaps a large majority of the farmers of the country cannot, however, patronize manufacturers of stave silos because the expense of shipping the lumber and fixtures would be prohibitory. For the convenience of such parties and others who may prefer to build their own stave silos, directions for their construction are given in the following. The specifications for a roo-ton stave silo, printed below, which are taken from Woll's Book on Silage, were furnished by Claude \& Starck, Architects, Madison, Wisconsin :

\section{Specifications for a roo-ton Stave Silo.}

MASONRY.

Excavate the entire area to be occupied by the silo to a depth of six inches; excavate for foundation wall 
to a depth of $x 6$ inches; in this trench build wall I $\delta$ inches wide and 20 inches high, of field stone laid in rich lime mortar. Level off top and plaster inside, outside and on top with cement mortar, I part cement to I part sand. Fill inside area with four inches of good gravel, thoroughly tamped down; after the wood work is in place coat this with one inch of cement mortar, I part cement to I part clean sand. Cement shall be smoothly finished, dished well to the center
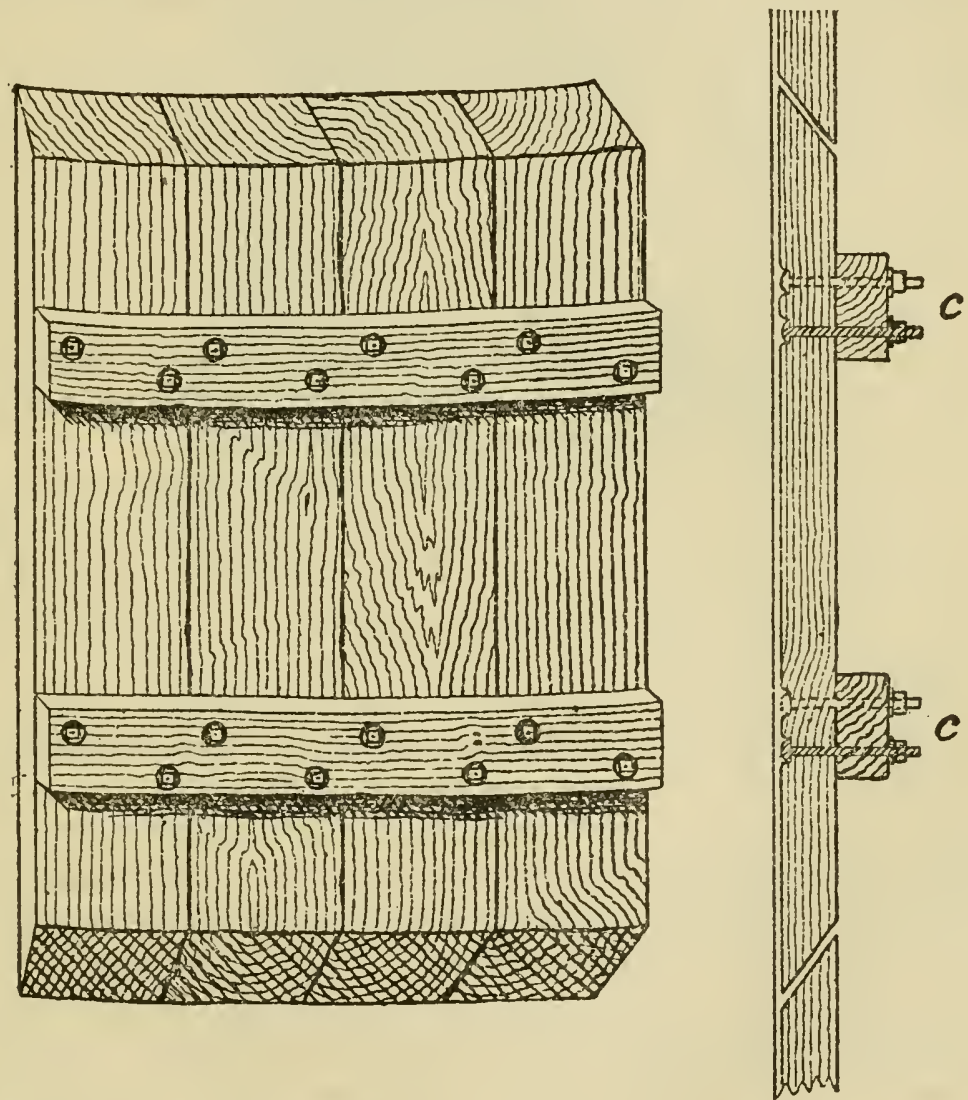

Fig. I3. Appearance of door in stave silo after being sawed out, and side view in place. The opening is largest on the inside of silo. (Clinton.) 
and brought up at least 2 inches all around inside and outside walls.

\section{CARPENTRY.}

All staves shall be 26 feet long in two pieses, breaking joints, and made from clear, straight-grained cypress $2 \times 6$ inches, beveled on edges to an outside radius of 8 feet, mill-sized to the exact dimensions and dressed on all sides. There shall be three doors in the fifth, eighth and tenth spaces between hoops, made by cutting out from staves 28 inches long cut to a 45 degree bevel sloping to the inside. (See Fig. 13.) The staves shall then be fastened together witl two $2 \times 4$-inch battens cut on inside to an 8 -foot radius and bolted to each stave with two $1 / 4$-inch diameter carriage bolts with round head sunk on inside and nut on outside. The staves between the doors shall be fastened together, top and bottom, with $3 / 4$-inch diameter hardwood dowel pins, and abutting ends of staves shall be squared and toe-nailed together.

Bottom Plates.-Bottom plates shall be made of $2 \mathrm{x}_{4}$ inch pieces about 2 feet long, cut to a curve of 7 feet ro inches radius outside. They shall be bedded in cement mortar and the staves shall then be set on the foundation and well spiked to these plates.

Hoops. - Hoops shall be made from two pieces of $5 / 8$-inch diameter round iron with upset ends, threaded 8 inches, with nut and washer at each end ; as a support for the hoops a piece of $4 \times 6$-inch shall be substituted for a stave on opposite sides and holes bored in it and the ends of hoops passed through these holes and tightened against the sides of the $4 \times 6$-inch. The hoops shall be twelve in number starting at the bottom 6 inches apart and increasing in distance 6 inches between each hoop until a space of 3 feet 6 inches is reached; from this point up this distance shall be preserved as near as possible to the top.

Roof.-Roof shall be made to a half-pitch of 6 -inch 
clear siding lapping joint, nailed to $2 \times 4$-inch rafters, 2 -feet centers, $\mathrm{I}$-foot by 4 -inch ridge, and $2 \times 4$-inch plates. These plates to be supported on two $4 \times 4$-inch pieces resting on top of hoops. Three $1 \mathrm{x}_{4}$-inch collar beams shall be spiked to end and middle :afters to tie

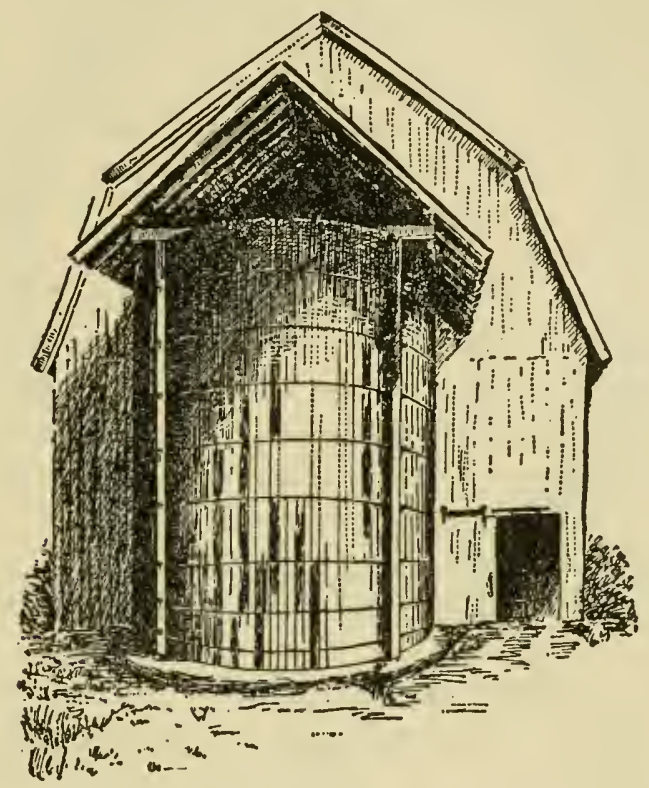

Fig 14, A cheap roof of stave silo. (Clinton.)

side of roof together. (See Fig. I I.) Fig. 14 shows another simple construction of roof on a stave silo.

\section{PAINTING}

The entire outside of the silo, including roof, shall be painted two coats of good mineral paint; the entire inside surface of staves and doors shall be thoroughly coated with hot coal tar.

Note. - Before filling silo, tar paper should be tacked tightly over doors and the entire inside of silo examined and all cracks tightly caulked.

The method of construction specified in the preced- 
ing may of course be modified in many particulars, according to the conditions present in each case, cost of different kinds of lumber, maximum amount of money to be expended on silo, etc.

The following directions for the construction of stave silos are taken from two bulletins on this subject, published by the Cornell and Ottawa Experiment Stations. For a silo 20 feet in diameter, a circular trench is inches to two feet wide and with an outer diameter of 22 feet is dug about 2 feet deep, or below the frost line. The surface soil over the whole included area, and for 2 feet outside, is removed to a depth of 10 or 12 inches at the same time. The trench is then filled to the level of the interior with stone, well pounded down, the surface stone being broken quite small, and thin cement (I part of cement to 4 of sand thoroughly mixed) poured over, well worked in and left for a few days. This is followed by a coat of good cement ( I part cement to 3 sand), care being taken when finished to have the surface level and smooth.

The silo is set up as shown in Fig. I5, which shows a cross-section of one method of construction.

The posts $(a, a, a, a)$ should be of $6 \times 6$ material and run the entire length of the silo. These should be first set up vertically and stayed securely in place.

The scaffolding may be constructed by setting up 2 by 4 scantling in the positions shown in Fig. I5, as $b, b, b, b$. Boards nailed from these 2 by 4 scantling and to the 6 by 6 posts will form a rigid framework, across which the planks for the scaffold platform may be laid. Before the scaffolding is all in place the staves should be stood up within the inclosure; otherwise difficulty will be experienced in getting them into position.

It is probable that no better material can be obtained for the staves than Southern cypress. This, however, is so expensive in the North, as to preclude its 


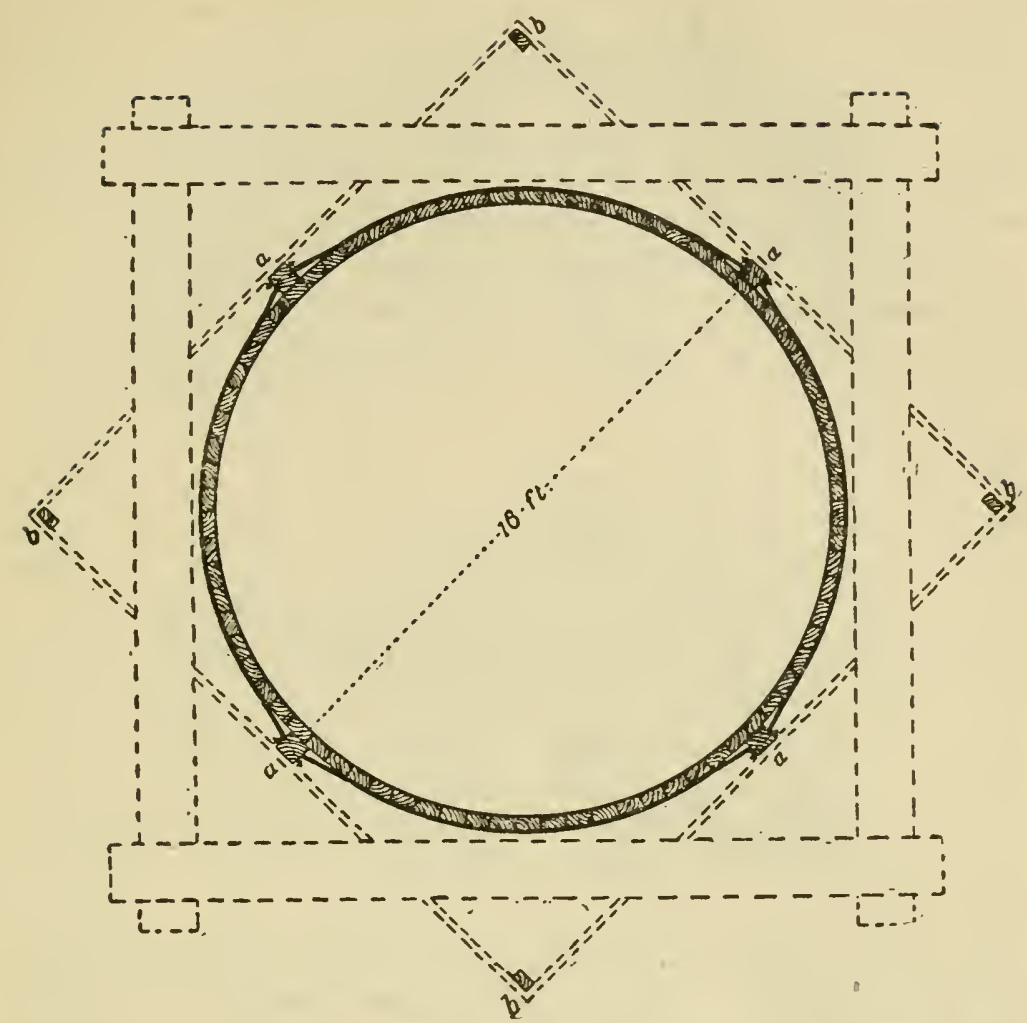

Fig. I5. Cross section of stave silo. The dotted lines show how scaffolding may be put up.

use in most cases. Of the cheaper materials hemlock, white pine, and yellow pine, are usually the most available. At the present time hemlock is one of the cheapest satisfactory materials which can be purchased, and it is probably as good as any of the cheaper materials. It should be sound and free from loose knots.

If the silo is to have a diameter of 12 feet or less, the staves should be made of either 2 by 4 material, unbeveled on the edges and neither tongued nor grooved, or of 2 by 6 material beveled slightly on the 
edges to make the staves conform to the circular shape of the silo. If the silo is to have a diameter of more than 12 feet, the staves should be of 2 by 6 material, and neither beveled nor tongued and grooved on the edges. The staves should be surfaced on the inside so that a smooth face may by presented which will facilitate the settling of the silage. The first stave set up should be made plumb, and should be toe-nailed at the top to one of the posts originally set. Immediately a stave is set in place it should be toe-nailed at the top to the preceding stave set. It has been found that the work of setting up and preserving the circular outline may be materially aided by the use old barrel staves (see Fig. I6). For a silo I 2 feet in diameter the curve in the stave of the sugar barrel is best adapted; for a I6-foot silo the flour barrel stave is best, and for a silo 20 feet or more in diameter the stave of the cement barrel is best. If when the silo staves are put in place they are toe-nailed securely to the ones previously set; if they are fastened firmly to the permanent upright posts (Fig. I $5, a, a, a, a$ ); if the barrel staves are used as directed above, the silo will have sufficient rigidity to stand until the hoops are put in place. However, if it becomes necessary for any reason to delay for any considerable time the putting on of the hoops, boards should be nailed across the top of the silo.

When it is found impossible to secure staves of the full length desired, a joint or splice must be made.

For a silo 30 feet deep, staves 20 feet in length may be used. A part of these should be used their full length and part should be sawed through the middle, thus making staves of 20 and ro feet length. In setting them up the ends which meet at the splice should be squared and toe-nailed securely together. They should alternate so that first a long stave is at the bottom then a short one, thus breaking joints at ro feet and 20 feet from the base. 

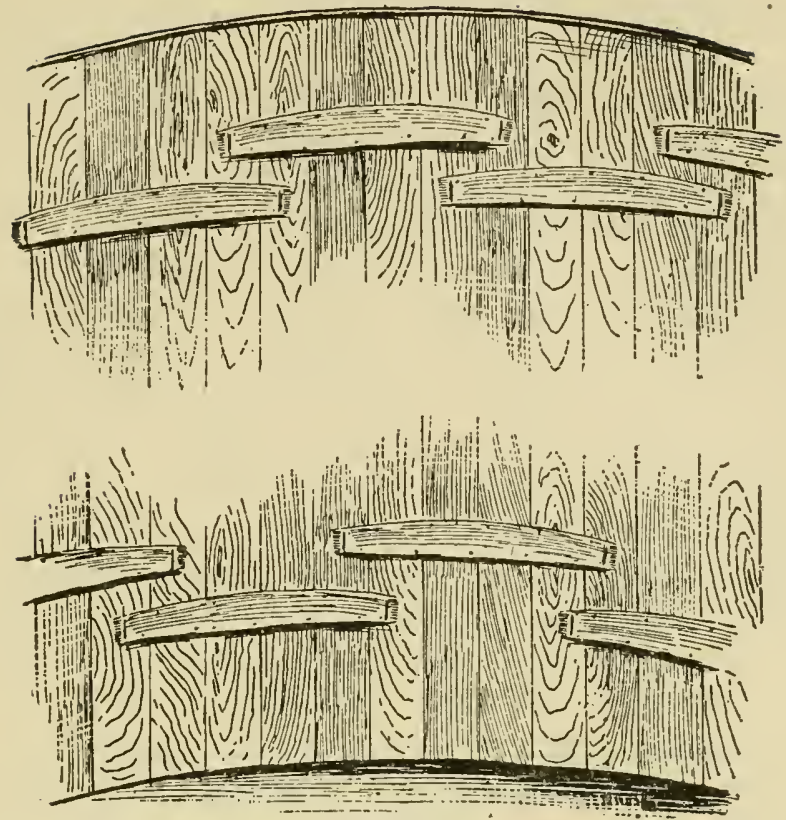

Fig, I6. Shows how barrel staves may be used in setting up a silo, they should be removed before the silo is filled.

For the hoops, 5/8-inch round iron or steel rods are recommended, although cheaper substitutes have been found satisfactory. Each hoop should be in three sections for a silo 2 feet in diameter, in four sections for a silo 16 feet in diameter. If the method of construction shown in Fig. I 5 is followed, the hoops will need to be in four sections each, the ends being passed through the upright $6 \times 6$ posts, and secured by heavy washers and nuts. The bottom hoop should be about six inches from the base of the silo; the second hoop should be not more than two feet from the first; the the third hoop two and one-half feet from the second, the distance between hoops being increased by onehalf foot until they are three and one-half feet apart, which distance should be maintained except for the 
hoops at the top of the silo which may be four feet apart. The hoops should be drawn fairly tight before the silo is filled, but not perfectly tight. They must be tight enough to close up the space between the staves, thus preventing any foreign matter from getting into the cracks which would prevent the staves from closing up as they swell, and allowing air to enter. To hold hoops and staves in place during the summer when the silo is empty, staples should be driven over the hoops into the staves. If a sufficient number of staples are used they will prevent the sagging or dropping down of the hoops, and they will hold the staves securely in place.

The hoops should be watched very closely for a few days after the silo is filled. If the strain becomes quite intense the nuts should be slightly loosened. If during the summer when the silo is empty and the staves thoroughly dry the hoops are tightened so that the staves are drawn closely together, when the silo is filled and the wood absorbs moisture and begins to swell, the hoops must be eased somewhat to allow for the expansion.

The doors, $\cdot 2$ feet wide by $2 \mathrm{r} / 2$ feet high, should be located where convenience in feeding dictates. The lower door should be between the second and third hoops at the bottom, and other doors will usually be needed in every second space between there and the top, except that no door will be needed in the top space, as the silage when settled will be sufficiently low to enable it to be taken out at the door in the space below. Plans should be made for the doors at the time the staves are set. When the place is reached where it is desired to have the doors, a saw should be started in the edge of the stave at the points where the top and bottom of the doors are to come. The saw should be inserted so that the door can be sawed out on a bevel, making the opening larger on the inside of the silo. (See Fig. I3.) This will enable 
the door to be removed and put in place only from the inside, and when set in place and pressed down with silage the harder the pressure the tighter will the door fit. After the silo is set up and the hoops have been put on and tightened the cutting out of the doors may be completed. Before doing this, cleats 2 inches by 3 inches and in length equal to the width of the door, should be made which will conform to the circular shape of the silo. One of these cleats should be securely bolted to the top and one to the bottom of where the door is to be cut. (See Fig. I3.) After the bolting, the door may be sawed out, and it is then ready for use. When set in place at time of filling the silo a piece of tarred paper inserted at the top and bottom will fill the opening made by the saw and prevent the entrance of any air around the door.

\section{Another Door for Stave Silo.}

Silage being heavy to handle, and pitch up, has made continuous doors a popular feature of a few factory-built silos, as it is much easier to get the silage out of the silo for feeding. The illustration, Fig. I7, shows a method of making a door in home-made silos which is continuous with the exception of a narrow brace piece extending across the opening, under each hoop, to give rigidity to the structure. These pieces should be securely toe-nailed at each end to the staves. The jamb pieces, $e, e$, should be 2 inches thick, beveled off on the side away from the door, securely spiked to the inside of the stave, as shown, so as to leave a rabbet $2 \times 2$ inches. Great care should be taken to have these pieces exactly the same distance apart throughout their entire length, so that the door boards, being sawed the exact length, will fit alike and properly all the way up, and if care be taken in this regard it will not be necessary to replace them in the same order at each successive filling of the silo. The door boards should be matched, two inches thick the same 

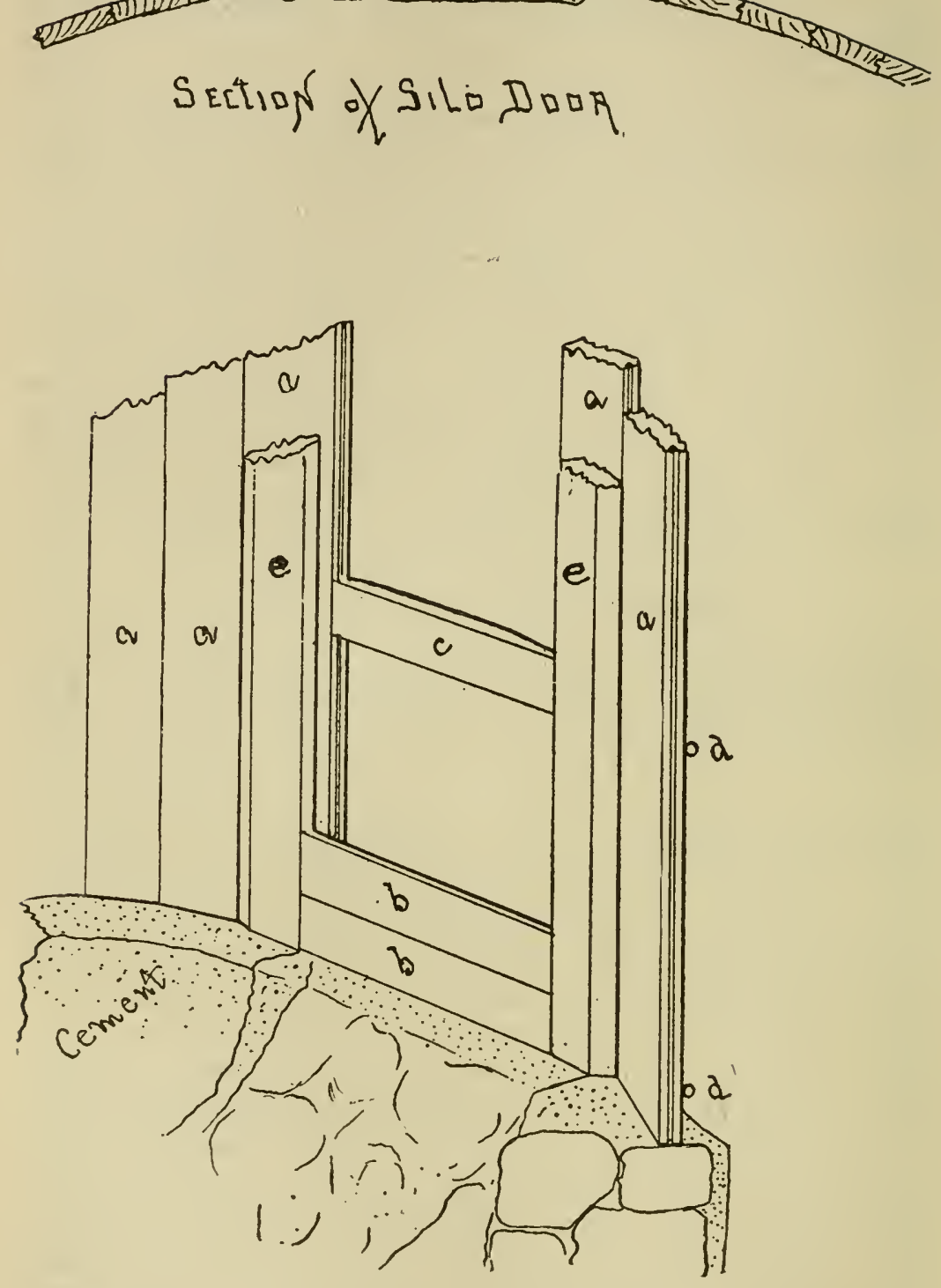

Fig. 17. $a, a$, Staves. b, b. Door Boards. c, Brace 21/2 by 6, set in. d, d, Hoops. e, e, Jamb pieces. 
as the staves, and if surfaced and well seasoned there need be no fear of the silage spoiling around such a door. A strip of acid-and water-proof paper may be placed in the rabbet, between the ends of the door boards and the stave, as an extra precaution, but if the carpenter work is well done it is not absolutely necessary.

Such a dnor can be adapted to any form of stave silo, and, if not made more than two feet wide, the fact that the door section is straight instead of curved will make no difference.

If the silo is built outside of the barn some sort of a roof is desirable. This should be sufficiently wide to protect the walls of the silo as thoroughly as possi-

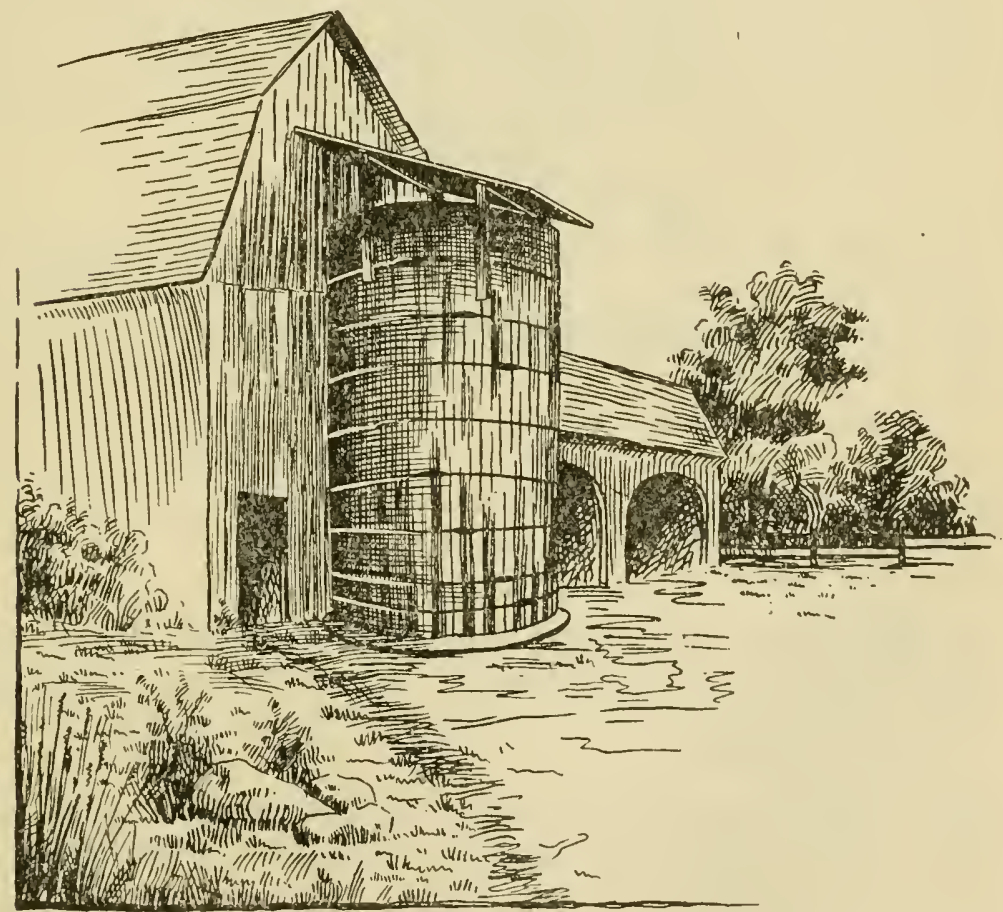

Fig. IS. A cheap roof for stave silos. 
ble. A very satisfactory roof is shown in Fig. I4. Two other constructions of a cheap roof for a stave silo are shown in Figs. I 8 and 19. The latter was built at the Indiana Experiment Station at a total cost of $\$$ IO. 50, viz., lumber $\$ 4.00$, tin put on and painted $\$ 6.00$ and hardware 50 cents. Two $2 \times 6$ pieces $(A, A)$

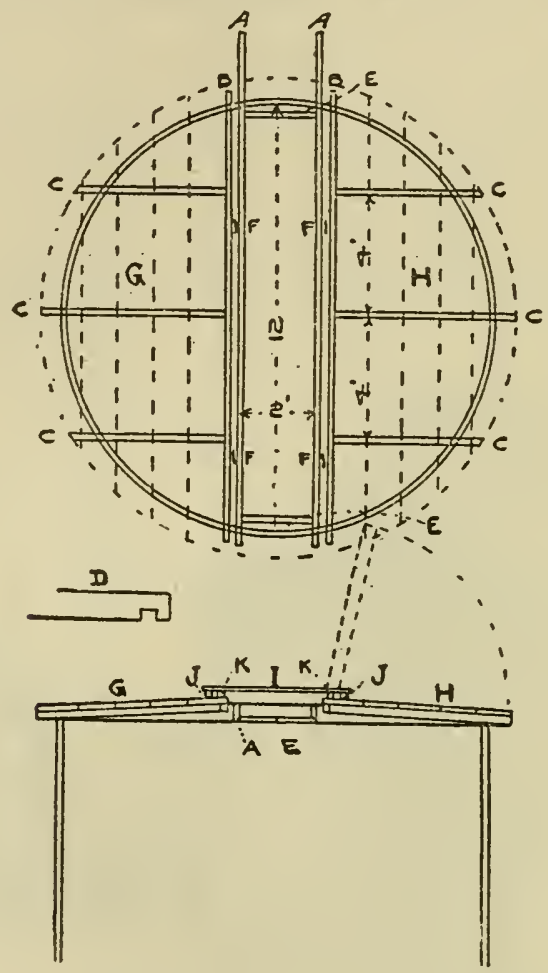

Fig. 19. A CHEAP ROOF OF STAVE SILO. $A, B$, and $E, 2 x 6$ in.; $C \cdot 2 x 4$ in.; $D, C$, Enlarged Outside End; $F$, Hinges; $G, H, I$, Sections of Roof; $J, K, 2 \times 2 \mathrm{in}$. (Van Norman.)

were placed on edge and toe-nailed to the top of the staves they rested on; the projection is for supporting the carrier at filling time. They are tied together by the short pieces $\mathrm{E}$. The roof is in three sections, $\mathrm{G}$, $\mathrm{H}$, and $\mathrm{I}$. $\mathrm{G}$ and $\mathrm{H}$ are hinged to the frame $\mathrm{A}, \mathrm{A}$, 
and may be tipped up when the silo is nearly full, to allow filling to the top. The narrow middle section is light enough to lift off on either side, and leaves the opening for the carrier to deliver into.

On the framework B, B, and C, C. cheap sheeting boards are nailed. This is then covered with tin, soldered joints and painted. The sections should be fastened down by means of staples and hooks, or other device; the hooks are used on this one. On the inner edge of $\mathrm{G}$ and $\mathrm{H}, 2 \times 2$-inch strips, $\mathrm{K}$, are nailed. Close to these are placed similar strips, J, to which the crossboards are nailed, forming the section I of the roof. The tin on the section I should come over the edge on to J. On the other sections it should run up on the side of $\mathrm{K}$, making a water-tight joint.

The sections $\mathrm{G}$ and $\mathrm{H}$ have slope of nearly 3 inches, being the difference in height of $\mathrm{A}$ and $\mathrm{C}$. $\mathrm{C}$ is notched one inch at the outer end. (Van Norman.)

\section{Cheap Stave Silos.}

A foundation-, bottom-, and roofless stave silo was described recently in Hoard's Dairyman, which may prove of interest and value to some readers. It was put up on a leased farm, with the expectation of removing it on the termination of the lease. It has the sky for a roof, the ground for a bottom, and no foundation but a $2 \times 6$ spruce scantling to secure a level base for the wall, while protecting them from rotting on the ground. The silo has a diameter of 24 feet, and is as high as could be built from $2 \mathrm{x}_{4}$ scantling without splicing them. The $2 \times 4$ spruce scantlings were set I 8 inches apart from center to center, upon a $2 \times 6$ sill, directly upon the ground, It was sheeted on the inside with two thicknesses of $1 / 2 \times 6$ spruce, with tar paper between. On the outside, at the bottom, half way up, and at the top, were two, three, and two bands of $\mathrm{ix} 6$ common fencing, respectively, and no other boarding. The silo has a capacity of 250 tons, 
and was built at a cost of \$I74.2I. "We never had better silage than we are now feeding out of this silo, though we did have to shovel nearly a foot off of it a few days ago, when the silo was operied.

Another very simple, home-made stave silo was built by the Virginia Experiment Station on a trial. The following is a brief description of this silo. It will be noted that neither doors nor roof were provided for in the silo.

A circle 16 feet in diameter is marked on the ground and covered with short pieces of plank. Four pieces of plank 16 feet long, 6 inclies wide, and 2 inches thick are then set on end on the circle at equal intervals. These are held in an upright position by braces in various directions. An iron band is placed about I foot from the bottom of the silo, and held in position by nails driven into the plank and bent up and over the band. A second band is placed about i foot from the top. The rest of the stares are then set in place, a nail being driven into each to support the bands. The latter are then tightened somewhat and 3 more put on, the distance between the bands being about + feet. Instead of hoops of round iron ordinarily used, bands made as follows are recommended :

Procure (as can ustually be done) partially worn tire iron from heary wagons. Get a smith to rivet, not weld, these together so that two bands will go around the silo. Rivet to the ends of these bands short pieces of iron one-half inch thick by 2 inches wide. Turn up 3 inches of this thick iron and punch three-fourth holes in the turned-up portion. For each band procure 2 bolts a foot long and three-fourth inch in diameter. Have threads cut on bolts nearly the entire length, and place these bolts through the holes in upturned ends; put on nuts and tighten the silo. These are stronger, clieaper, and easier to work than the round bands, and considered a great improvement over the latter. Objections have, however, been raised to 
flat iron hoops, that the woodwork under them is apt to rot, and round hoops are generally recommended for this reason.

\section{A Modification of the Stave Silo.}

Stave silos are admittedly cheap and readily put up, but unless hoops are tightened as they dry out, they may be easily blown into a shapeless mass in case of a heavy gale. The modification of the stave silo described in the following has the advantage of being more rigid and substantial; it has been put up in a number of places in the east, and has apparently given good satisfaction for several years, at least. In building this silo some good, tough, oak planks two inches thick and of any convenient length are procured. Rock elm will do, although not as good as oak. The planks are sawed into strips half an inch thick. The foundation of the silo is made of concrete, and a little larger than the outside diameter of the silo. A stake is set in the center and on this a piece is nailed, just long enough to act as a guide in setting scantling when erecting sides. For sides $\mathrm{I} 1 / 2 \mathrm{x} 4$ inch hemlock of any desired length is used. These are set up on the circumference of the silo, perpendicular to the bottom. 3 feet and 7 feet up nail on the outside one of the half-inch strips mentioned before, being sure to keep the circle regular. This will keep upright pieces in place until the circle is conpleted. On each hoop so started other half-inch pieces are nailed, lapping them in different places until each hoop is three inches thick. Other hoops are now put on in the same manner, placing them one foot apart at bottom, up to the threefoot hoop i 6 inches apart from three to the 7 -foot hoop, then increasing the distance between each hoop two inches, until they are 30 inches apart, at which distance they should be kept. If staves are to be spliced it should be done on the hoop. When this is done, a silo will 
be made of $\mathrm{I} / 2 \mathrm{X}_{4}$ inch, thoroughly hooped with wooden hoops $2 \times 3$ inches.

The inside may be covered with the best quality of felt, well tacked to the staves, on which a thick coat. of thick coal tar is spread; over this another thickness of felt is put while the tar coating is still green. The silo is lined with $3 / 8$-inch Georgia pine ceiling, nailing thoroughly, and the lining coated with two coats of coal tar, putting on the first one quite thin, but using all the wood will take in, and for a second coat tar as thick as it can be spread. Give plenty of time to dry before filling.

The outside of the silo may be boarded up with rertical boarding, or it may have strips nailed on hoops and be boarded with novelty siding. The latter method will make a stronger and better looking silo. If the hoops are well nailed "to the staves when being made, we shall have a silo in which it is impossible for the staves to shrink or get loose. (Woodward.)

Peer, in his book "Soiling, Soiling crops and Ensilage," reports that a New-York canning factory who has for years siloed their pea vines, corn husks and cobs, and wintered sheep thereon, put the refuse through a cutting box into a rough plank silo about thirty feet in diameter. "The planks were rough, just as they came from the saw mill, set on end, and hooped with half-inch round iron. No roof was put on, and when the silage settled the staves were taken down, the silage stood, and the whole mass kept in perfect form. The following year the staves ( $2 \times 6$ inch planks) are set up again. As to the silage spoiling, there is six or eight inches on the sides that rots, and is thrown into the manure heap. As to freezing, they experience no inconvenience from that. If the top freezes a little, it is mixed with the unfrozen, fermentation sets up, and the frozen part is thawed out by its own combustion."

Protection against freezing. It the silo is built out- 
doors in any of the Northern states, it is necessary to provide some special means to keep the silage from freezing in case this is considered a very objectionable feature. The silo may be enclosed by a wide jacket of rough boards nailed to four uprights, leaving the section of the silo where the doors are easy of access; the space between the silo and outside jacket is filled with straw in the fall; this may be taken out and used for bedding in the spring, thus allowing the staves to be thorouglily dried out during the summer, and preventing the silo from rotting.

Number of staves required for stave silos.-The following table will be found useful in calculating the number of stares required for silos of different diameters, and the feeding areas which these will give:

CIRCUMFERINAES AND AREAS OF CIRCLES.

\begin{tabular}{|c|c|c|c|c|c|}
\hline $\begin{array}{c}\text { Dianieter. } \\
\text { Feet. }\end{array}$ & $\begin{array}{l}\text { Circum- } \\
\text { ference. } \\
\text { Feet. }\end{array}$ & $\begin{array}{c}\text { Area, } \\
\text { Sinnare } \\
\text { Feet. }\end{array}$ & $\begin{array}{c}\text { Diameter, } \\
\text { Fect. }\end{array}$ & $\begin{array}{c}\text { Circuni- } \\
\text { ference, } \\
\text { Feet. }\end{array}$ & $\begin{array}{l}\text { Area, } \\
\text { Square } \\
\text { Feet. }\end{array}$ \\
\hline $\begin{array}{c}8 \\
9 \\
10 \\
35 \\
12 \\
13 \\
14 \\
15 \\
16 \\
17 \\
18 \\
19 \\
20\end{array}$ & $\begin{array}{l}25.1 \\
28.3 \\
31.4 \\
34.6 \\
37.7 \\
40.8 \\
44.0 \\
47.1 \\
50.3 \\
53.4 \\
56.5 \\
59.7 \\
62.8\end{array}$ & $\begin{array}{r}50.3 \\
63.6 \\
78.5 \\
05.0 \\
113.1 \\
132.7 \\
153.9 \\
179.7 \\
201.1 \\
227.0 \\
254.5 \\
283.5 \\
314.2\end{array}$ & $\begin{array}{l}21 \\
22 \\
23 \\
24 \\
25 \\
26 \\
27 \\
25 \\
29 \\
3.1 \\
3 ! \\
32\end{array}$ & $\begin{array}{r}66.0 \\
69.1 \\
72.3 \\
65.4 \\
78.5 \\
81.7 \\
84.8 \\
88.0 \\
91.1 \\
94.2 \\
97.4 \\
100.5\end{array}$ & $\begin{array}{l}346.4 \\
380.1 \\
415.5 \\
452.4 \\
490.9 \\
530.9 \\
572.6 \\
615.8 \\
660.5 \\
706.9 \\
754.8 \\
804.2\end{array}$ \\
\hline
\end{tabular}

To find the circumference of a circle, multiply the dianleter by 3. I 4 I 6 .

To find the area of a circle, multiply the square of the diameter by 0.7854 .

To find the cubical contents of a cylinder, nultiply the area of the base (floor) by the height.

Example.-A silo 16 feet in cliameter and 26 feet ligh is wanted; how many staves $2 \times 6$. inches will be 
needed, and what will be the feeding area in the silo, and its capacity?

The circumference of a circle 16 feet diameter \& 50.3 feet; there will therefore be required $50.3 \div 1 / 2 \mathrm{~s}$ IOI staves, $2 \times 6$ inches, 26 feet high, or if staves of this height cannot be obtained, I 35 staves 20 feet long, or 50 each of $\mathrm{I} 2$ and $\mathrm{I} 4$ feet long staves. The feeding area will be $16 \times 16 \times 0.7854=201 . I$ square feet, and the cubical content of the silo, 2OI. I $\times 26=5228.6 \mathrm{cu}$ bic feet. Estimating the weight of a cubic foot of corn silage at 40 pounds, 5228.6 cubic feet silage would weigh 209 , I 64 pounds, or about Ioo tons, which is the approximate capacity of a round silo of the dimensions given.

Connecting Round Silos with Bam.-The location of the silo with reference to other farm buildings has already been discussed. The silo must be easy to get at from the stable, and the silage, if possible, handled only once in being placed before the stock. A round silo is most conveniently built just outside of the barn and connected with this by means of a covered passage way. The method of joining silos to barns is i1lustrated in numerous pictures of silos given in this book. See Fig. 20.

\section{Other forms of Round Silos.}

The variois types of round, wooden silos have been described at some length in the preceding, because perhaps ninety per cent. of farmers who expect to build a silo will build one of this kind, either one of the more substantial and expensive original or modified Wisconsin silos, or a stave silo. In some cases it seems more desirable to build a round silo of other material than wood, viz., of either stone or brick. The general principles that must be observed in constructing silos of these materials are similar to those underlying the proper construction of wooden silos. In order to strengthen the wall of the silo, it is re- 
ILLUSTRATION.

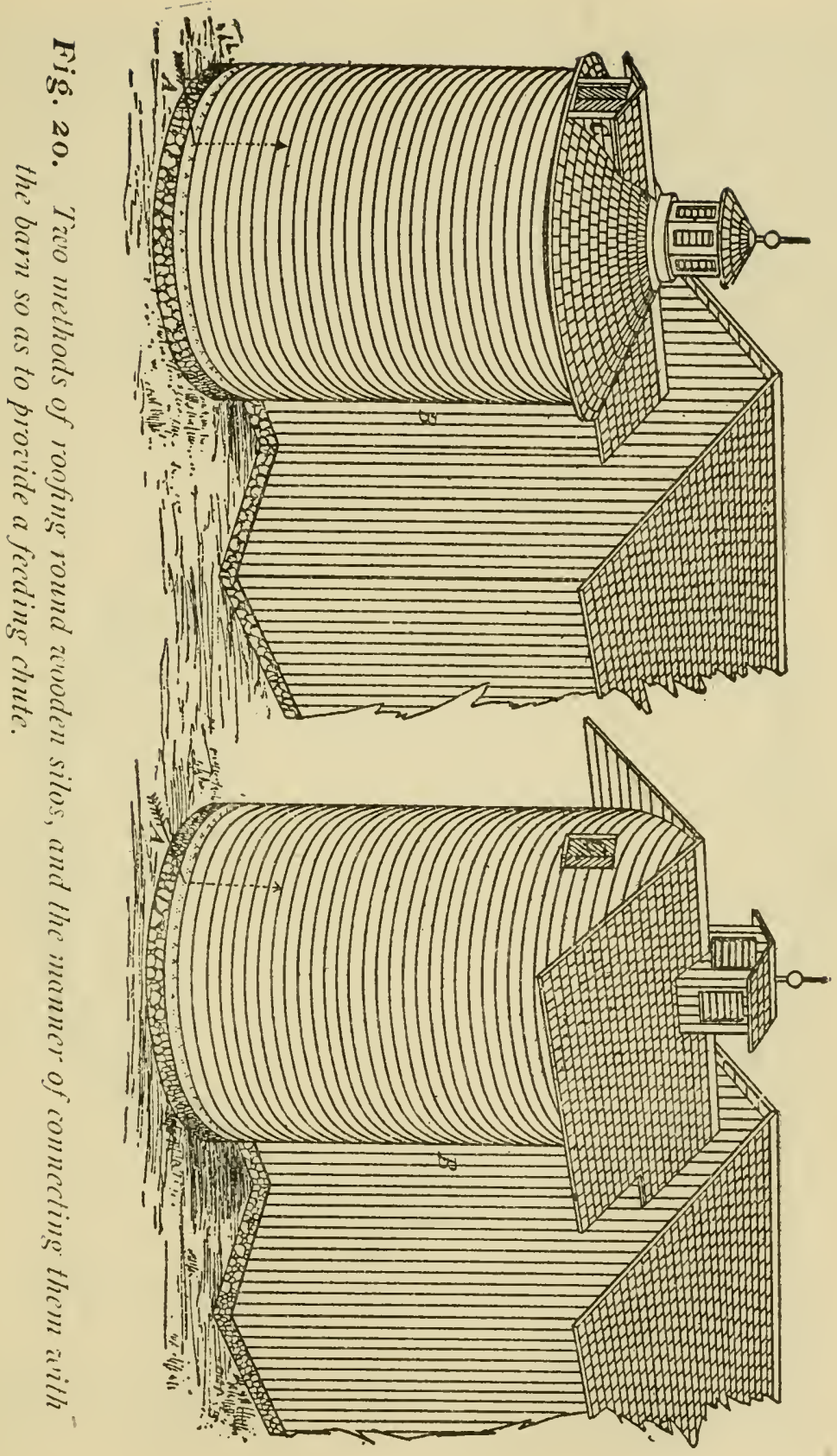


commended to bed in the wall between the doors $5 / 8$ inch iron rods, bent to the curve of the silo circle, and about $\mathrm{I} 2$ feet long. The two ends should be turned short at right angles, so as to anchor better in the mortar. In deep stone silos, which rise more than 18 feet above the surface of the ground, it will be safest to strengthen the wall between the two lower doors with iron tie rods, and, if such a silo is built of boulders, it will be well to use rods enough to make a complete line or hoop around the silo about two feet above the ground, as represented in Fig. $2 \mathrm{I}$.

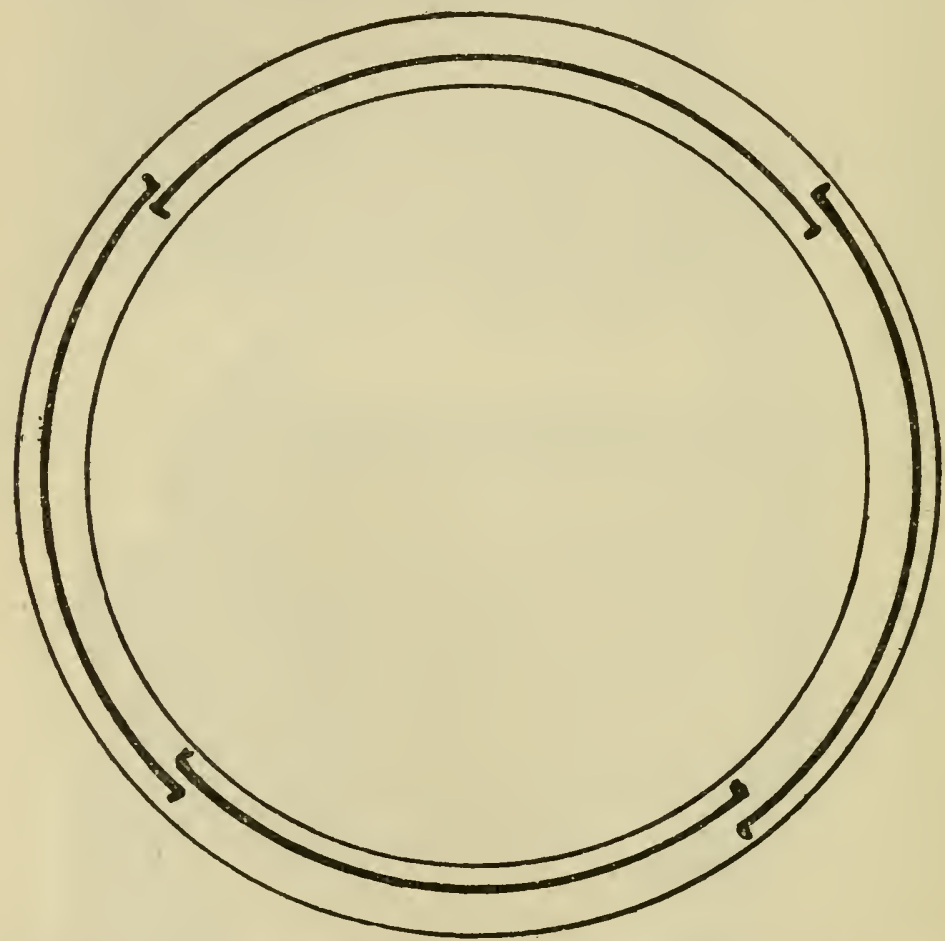

Fig. 21. Showing method of bedding iron rods in stone, brick, or concrete walls to increase the strength.

Too great care cannot be taken in making the part of the wall below and near the ground solid, and es- 
pecially its outer face, so that it will be strong where the greatest strain will come. It is best also to dig the pit for the silo large enough so as to have plenty of room outside of the finished wall to permit the earth filled in behind to be very thoroughly tamped, so as to act as a strong backing for the wall. This is urged because a large per cent. of the stone foundations of wood silos have cracked more or less from one cause or another, and these cracks lead to the spoiling of silage.

Flat quarry rock, like limestone, will make the strongest silo wall, because they bond much better than boulders do, and when built of limestone they will not need to be reinforced much with iron rods. It will be best even in this case, however, to use the iron tie rods between the lower two doors. (King.)

Brick Silos.-In constructing a brick silo it will be well to guard the following points: Make the foundation of stone if practicable, and let the first course of brick come flush on the inside with the stone work. Bed a five-eighths inch iron hoop in the stone work in the upper part before laying the brick, in order to keep the pressure of brick from spreading the wall before the mortar becomes set and hard. Make a twoinch air space in the walls up to within one-third of the top. This will make a I4 inch wall of three courses of brick. If, however, the silo is to be over 24 feet inside diameter, then a four-brick wall is really necessary one-third the way up, then the next third of three bricks and the last third of two bricks. The air space should be in the outer part of the wall. Iron tie rods should also be laid around in the wall between the doors, as recommended in the stone work. It is also important that the brick should be wet when laid, otherwise the mortar in which they are laid will be dried out too rapidly. The walls should be plastered over very smoothly with a coat of rich cement, onefourth to one-half inch thick, and then every two or 
three years this should be well whitewashed with thin cement, to keep the wall protected from the effects of acid in the silage. King recommends that the floor jambs be made of $3 \times 6^{\prime} \mathrm{s}$ or $3 \times 8$ 's, rabbetted two inches deep to receive the door on the inside. The center of the jambs outside should be grooved and a tongue inserted projecting three-fourths of an inch outward to set back into the mortar, and thus secure a thoroughly air-tight joint between wall and jamb. The doors may be made of two layers of matched flooring with tarred paper between, and lag screw bolted to the jamb, so as to give a perfectly smooth face next to the silage.

Stone Silos. - The stone silo should have a wall about two feet thick below the surface of the ground, and this may be laid in the cheaper grades of cement. Above the surface a good grade of Portland cement should be used. A thickness of wall of is inches at the surface of the ground is desirable, but this may be gradually reduced to $\mathrm{I} 2$ inches at the top, keeping the inner surface of the silo perpendicular. It is important to have five-eighths incli iron rods, with angles on the ends, laid in the wall at intervals betreen each door, to keep the walls from cracking or spreading before the mortar or cement is thoroughly set. These rods may be of several lengths, laid to the curve of the wall. and the angled ends should lap by each other for three or four inches.

It will be well to place silos a distance below the surface. This should not be deep enough on level land, however, to require great exertion to get out the silage. Under such circustances four feet is deep enough. (Plumb.)

Details concerning the construction of stone, brick, and cement silos are given in Prof. Woll's Book on Silage, and in Bulletin No, 83 of Wisconsin Experiment Station, by Prof. King, as well as in numerous other silo pamphlets, and we shall not take up fur- 
ther space here with the discussion thereof. The same holds true with all other forms of silo construction than those already explained, except the one kind, where silos are built in a bay of the barn. In order to use the space economically, these silos are built in a rectangular form.

\section{Silos in the Barn.}

A large number of silos have been built in the barn, especially in the early days of silo construction. Where the necessary depth can be obtained and where the room can be spared, such silos can be built very easily and at a less cost than a separate structure, since lighter materials in construction may be used in this case, and no roof will be required for the silo. Silos built in this manner have generally the advantage of being near at hand. Since feeding time comes twice a day, at least, throughout the winter and spring, a few steps saved in hauling the silage mean a good deal in the aggregate. Many farmers first made silos of this kind, and, later on, when familiar with the silage and siloing process, built additional separate structures.

A very cheap rectangular silo may be constructed by erecting strong $3 \times 10$ studding around a bay or part of a bay, and lining with one-ply good matched lumber one inch thick. Such a silo has been in use at the Ottawa Station for eight years, and has given good results. The following detailed directions for changing bays in a barn into silos were originally published by the N. H. Experiment Station.

Remove floors, and if there is a barn cellar place sills on the bottom of this, and set $2 \times 8$ scantling vertically, bringing up the inside edges even with the sills of the barn. The bottom may or may not be cemented, according as the ground is wet or dry, If it be cemented, three casks of cement and an equal amount of sharp sand or gravel will cover a bottom i $6 \times 16$ and 
turn up on the sides two feet, which will give a tight silo. Common spruce or hemlock boards, squareedged and planed on one side, are best for boarding the inside of the silo; these are to be put on in two courses, breaking joints, and, if thoroughly nailed, will give a tight silo. No tongueing or matching is needed. Tarred paper may be put between the boarding, if desired, but I doubt if it is of great utility. At some point most easily accessible, an opening extending nearly the height of the silo must be made, to put in the corn and take out the silage. The courses of boards should be cut shorter than the opening, to allow loose boards to be set in, lapping on the door studding and making an air-tight joint. For all this work medium lumber is good enough, and a very limited amount of mechanical skill and a few tools, which all farms should have, will enable most farmers to build their own silo. A few iron rods, one-half inch in diameter, may be necessary to prevent spreading by side pressure, but this will depend upon the strength of the original frame of the barn. Narrow boards, from five to eight inches wide, are better than wide ones, as they are not likely to swell and split. Eight-penny nails for the first boarding and twelvepenny nails for the second course will hold the boards in place.

A silo constructed as above outlined will cost from 50 cents to $\$ I$.oo for each ton of its capacity, according as all materfals, including lumber and stone, are charged, or only labor and nails, rods, and cement.

A Small $\$ 30$ Silo. -The illustration herewith given, Fig. 22, shows a small, square silo, built inside a Michigan barn; dimensions 8 feet square and 22 feet deep. The capacity of the silo is about 28 tons. It is built of $2 \times 8$ horizontal studding, placed lapped at the corners, and held together with 5 twenty-penny nails, wire spikes, in each corner. The space be- 


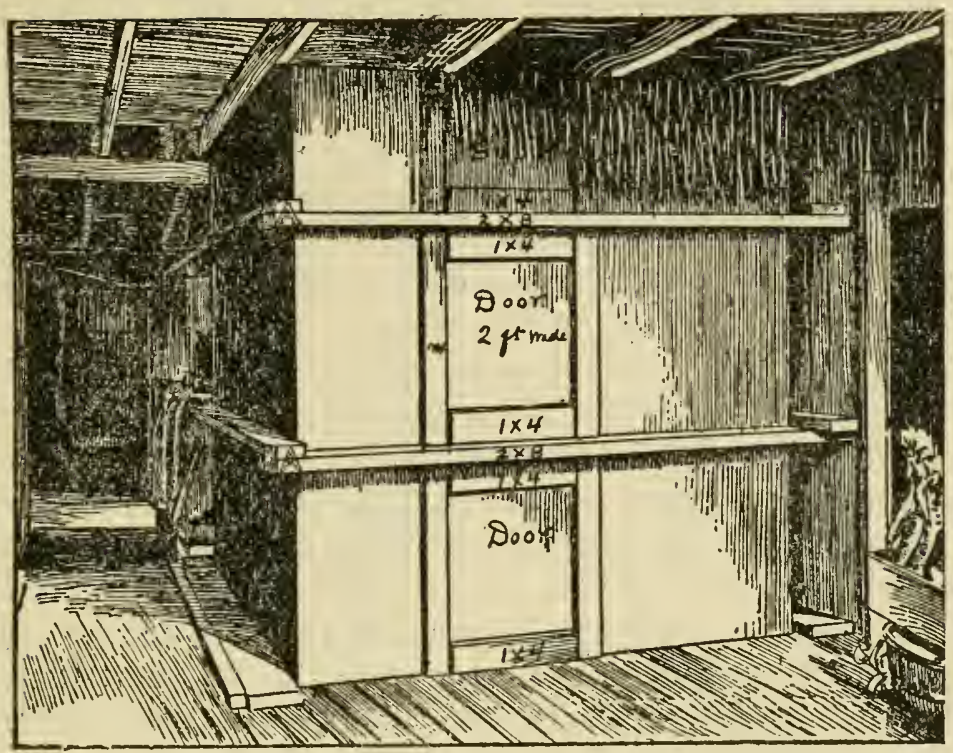

Fig. 22. View of a silo 8 feet square; 22 feet deep, built inside of barn. (Smith.)

tween these frames, from the bottom to the top, are $2 \mathrm{I} / 2,2 \mathrm{I} / 23,4,5$, and 5 feet. The siding consists of one thickness of matched white-pine flooring, six inches wide; it is nailed on vertically and painted on both sides with Venetian red and oil. No paper is used. 'The corners' are filled out by $2 \times 6$ scantling properly beveled and nailed in vertically. Each door is 2 feet wide, and made of sufficient length to lap an inch when placed between a certain pair of horizontal ribs; toward the bottom of the silo the doors are, therefore, $2 \mathrm{r} / 2$ feet high, while toward the top they are 5 feet high. Battens of $1 \times 4$ pine are placed over the cracks on the sides of the doors and nailed to the wall of the silo. No hinges are used, the pressure of the silage keeping the doors in place.

The bottom frame, formed by the $2 \times 8$ studdings, 
rests on the clay bottom of the barn cellar. The silo has no foundation, but the hard clay bottom is cemented with Buffalo cement, one inch thick, to keep out rats. Cost of materials, $\$ 30.00$.

The main objection to rectangular or square silos is that it is very difficult to make the corners perfectly tight, so that air will not enter at these points and cause more or less of the silage to spoil here. Even if carefully built, the lateral pressure in a silo filled with green fodder is often great enough to cause the boards to spring and thus let air in, unless special precautions have been taken to prevent it. One way of avoiding this difficulty is to partially round off the corners, by placing a square timber, split diagonally, in each of the oorners. Another plan is to bevel the edge of a ten-inch plank and nail it in the corners, filling in behind with dry dirt or sand. Sawdust has been recommended, but should not be used, as it will draw moisture and cause the plank and silo lining to decay. The space back of the plank may also be left empty.

The arrangement for making the corners of a square or rectangular silo air-tight shown in Fig. 23 was published by the Geneva Experiment Station. The cor-

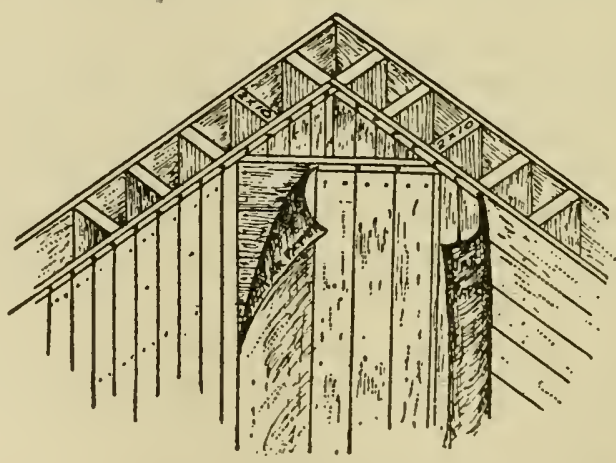

Fig. 23. Comer of Rectangular Silo. Wheeler. 
ners are boarded up, as shown in the figure, a sheeting of paper going between the two courses of boards. The partitions at the corners can be put across after the first course of boards, instead of after the lining is in place, as shown in the illustration.

The silos of the form mentioned may be strengthened at the corners by the arrangement recommended by Prof. Spillman and shown in Fig. 24. Half-inch

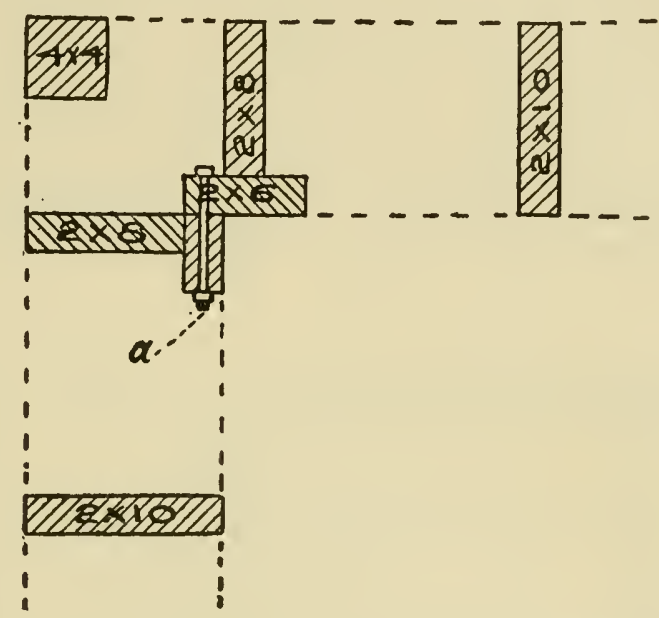

Fig. 24. Cross-section of the studding at the corner of a rectangular silo. Spillman.

bolts are used to hold the $2 \times 4$ and $2 \times 6$ together. The bolts are not more than eighteen inches apart from the bottom up to about the middle of the studding. Above the middle they may be two feet apart; they may be reinforced by 3 od. nails.

\section{Octagona1 Silos.}

A number of octagonal silos have built in recent years, and find favor with their owners in most instances. If properly put up and care taken to fasten the girts securely at the corners with plenty of spikes, the octagonal silo is greatly superior to the square 
type and has nearly every advantage of the round silo, and can readily be constructed by anyone handy with tools with the assistance of the ordinary farm help.

The foundation should be of stone or brick as described for various other forms of silos, and should be laid out with proper dimensions for the size decided upon. Brief details are here given for an octagonal silo of about the same capacity as a round silo, 20 feet in diameter and of equal height.

If the foundation is laid out so that the corners are in the circumference of a circle 2 I feet in diameter the horizontal girts will be about 8 feet long, and will be much stronger and better able to withstand the lateral pressure than the sides of a square silo of equal capac-

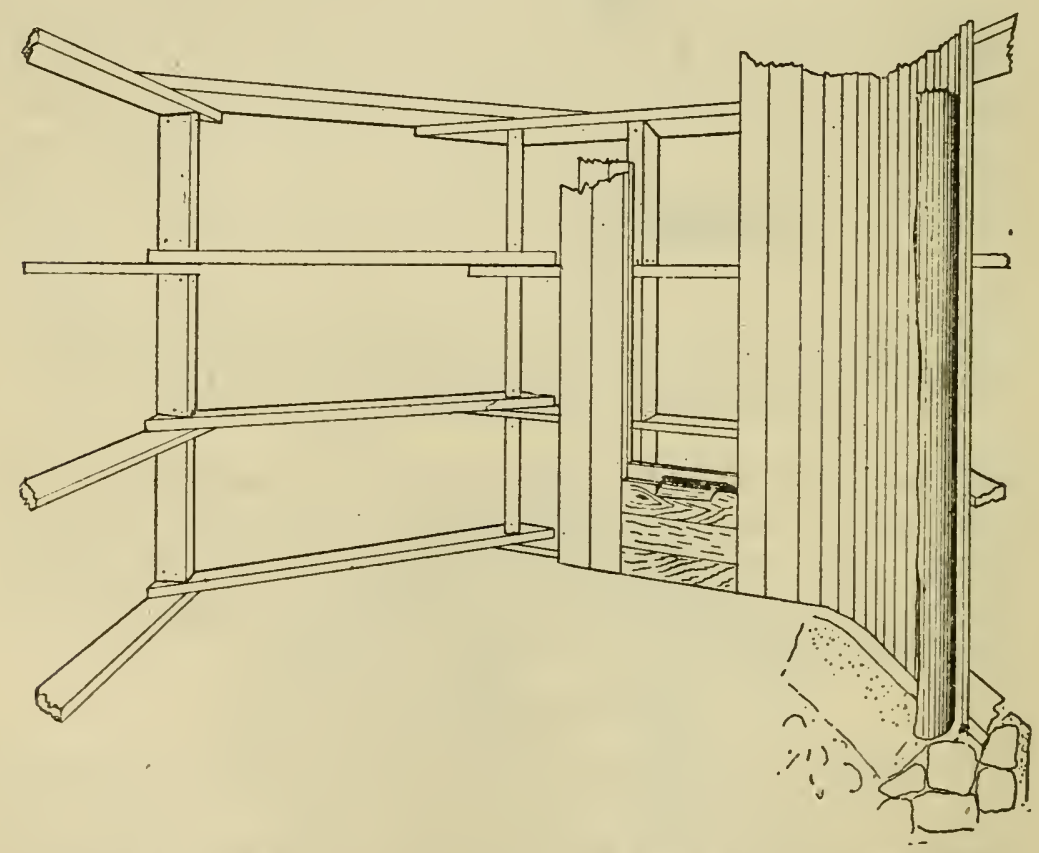

Fig. 25. Perspective showing construction of Frame, and double lining with paper between. The door is made of two thicknesses with paper between, as shown. 
ity. Details of construction are shown in the drawings, Figs. 25 and 26. The girts should be $3 \times 8$ in. and spiked at the corners with 6 inch spikes, up to nearly one-half of the height of the silo, and $2 \times 8$ in. the rest of the way, fastened with 20 penny spikes. The girts should be 16 inches apart at the bottom for one-third the height of the silo. They may be is inches apart the second third of the distance, and above that the distance between them can be increased till they are 2 feet or more at the very top. A double row may be used for a plate. Sound timber only should be used. Care should be taken to have the girts securely spiked at the corners, so that the joints will not give. The horizontal girt sections take the place of hoops in the round silo and must be strong. Not less than six or eight spikes should be used at each splice. One of the causes of failure in home-made silos of every kind is that the ordinary carpenter, who has probably never built a silo before, has but a limited idea of the pressure on the sides of a silo 30 or more feet deep, and does not realize the disappointment and loss occasioned by a poorly built silo.

A simple method of getting the walls perpendicular is to first lay the sill, which should be fastened to the wall securely, by means of bolts set in the wall, and then erect at each corner and on the inside a temporary post or scantling to serve as a guide, braced in position so that it is perpendicular both ways, and the girts then laid and spiked in position, one above the other.

The lining is, of course, put on up and down and should be matched and of good thickness, say $I / / 4$ or $I I / 2$ if but one layer is used. If two layers, it need not be so thick, 7/8-inch flooring, and the outer layer not necessarily matched. The corners should be fitted as nicely as possible, and it is a good plan to block out the corners, as shown at Fig. 26 , a, a, a, so that the tongues and grooves can be properly adjusted to eacl other. 
John Gould, a prominent dairy writer and lecturer, recommends, where one thickness of matched lumber

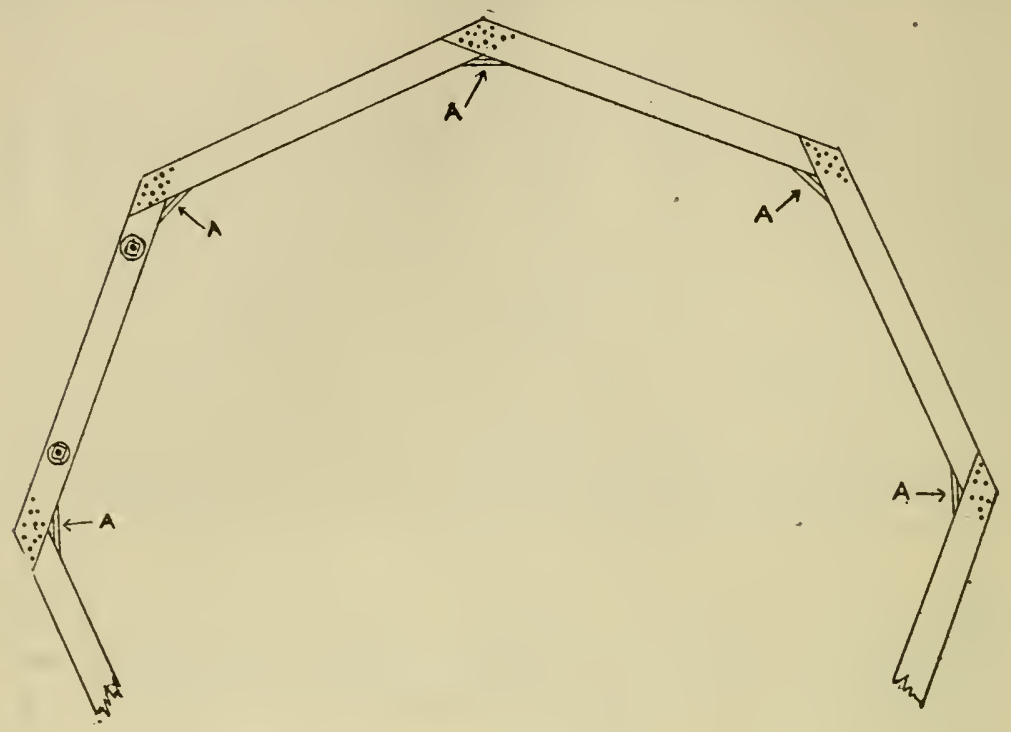

Fig. 26. Showing method of laying sill. and bolting same to foundation for an octagonal silo.

is used in the above manner, that the lining be thoroughly coated on the outside with heary application of coal tar, or other similar substance, so as to prevent the air penetrating the pores of the lumber, and causing the silage to dry on to the inner surface.

Any style of door can be used, but an effective continuous door is shown in the illustration. If any of the girts be cut out to make the door spaces larger, the remaining ones should be correspondingly reinforced.

The making of a roof for such a silo is a simple matter, and a dormer window will assist in filling, although a trap door may be used in case the filling be done with a blower. Any style of siding may be used.

Such a silo if well built will be durable, satisfactory, have nearly all the advantages of a round silo, and in 
addition will be a much more stable structure, requiring no tightening of the hoops from time to time.

Bill of materials for a silo built to $2 \mathrm{I}$-foot circle and 30 feet high are given below. The cost will, of course, vary with the locality.

Bill of materials for Octagonal Silo 20x3o feet outside measurement :

Foundation

Girts .

Io perches.

Rafters

$$
\left.\begin{array}{c}
\text { I oo feet } 3 \times 8 \\
900 \text { " } 2 \times 8
\end{array}\right\} \begin{gathered}
8 \text { or I } 6 \text { foot } \\
\text { lengths. }
\end{gathered}
$$
Siding . . . . . . . . . . . 2500 feet Lining . . . . 2800 feet, $\mathrm{I} / 4$ inch thick, matched Dormer Window

Nails and spikes . . . . . . . . . $300 \mathrm{lbs}$ Shingles... . . . . . . . . . . $4 \mathrm{M}$ Paint

\section{Cost of Different Kinds of Silos.}

The cost of a silo will depend on local conditions as to price of labor and materials; how much labor has to be paid for; the size of the silo, etc. The comparative data for the cost of two round silos, 13 and 25 feet in diameter, and 30 feet deep, is given by Prof.

\begin{tabular}{|c|c|c|c|c|}
\hline \multirow{2}{*}{ KINDS of SILo. } & \multicolumn{2}{|c|}{$\begin{array}{l}13 \text { FEET INSIDE } \\
\text { DIAMETER. }\end{array}$} & \multicolumn{2}{|c|}{$\begin{array}{l}25 \text { FEET INSIDE } \\
\text { DIAMETER. }\end{array}$} \\
\hline & $\begin{array}{l}\text { Without } \\
\text { roof. }\end{array}$ & $\begin{array}{l}\text { With } \\
\text { roof. }\end{array}$ & $\begin{array}{l}\text { Without } \\
\text { roof. }\end{array}$ & $\begin{array}{l}\text { With } \\
\text { roof. }\end{array}$ \\
\hline 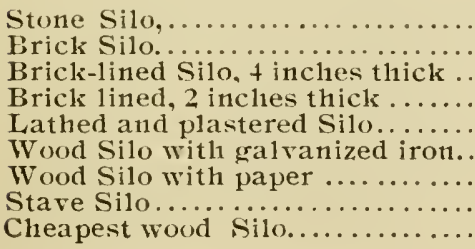 & $\begin{array}{r}\$ 151 \\
243 \\
142 \\
131 \\
133 \\
168 \\
128 \\
127 \\
101\end{array}$ & $\begin{array}{r}\$ 175 \\
273 \\
230 \\
190 \\
185 \\
185 \\
222 \\
183 \\
1+4\end{array}$ & $\begin{array}{r}\$ 264 \\
437 \\
310 \\
239 \\
244 \\
308 \\
235 \\
136 \\
195\end{array}$ & $\begin{array}{r}\$ 328 \\
494 \\
442 \\
369 \\
363 \\
432 \\
358 \\
289 \\
240\end{array}$ \\
\hline
\end{tabular}
$\mathrm{King}$, as shown in the following table: 
During the spring of 1895 Prof. Woll made inquiries in regard to the cost of silos of different kinds (not only circular ones), built by farmers in different states in the Union. The results of this inquiry are summarized briefly below.

The cheapest silos are those built in bays of barns, as would be expected, since roof and outside lining are here already at hand. Number of silos included, fourteen ; average capacity, I 40 tons ; average cost of silos, $\$ 92$, or 65 cents per ton capacity.

Next come the square or rectangular wooden silos. Number of silos included, twenty-five; average capacity, 194 tons; average cost of silos, $\$ 285$, or $\$ 1.46$ per ton capacity.

The round silos follow closely the square wooden ones in point of cost. Only seven silos were included, all but one of which were made of wood. Average capacity, 237 tons; average cost $\$ 368$, or $\$ 1.54$ per ton capacity. The data for the six round wooden silos are as follows; Average capacity, 228 tons ; average cost, $\$ 346$, or $\$ 1.52$ per ton capacity. The one round cement silo cost $\$ 500$, and had a capacity of 300 tons (dimensions: diameter, 30 feet; depth 21 feet); cost per ton capacity, \$1.67.

The stone or cement silos are the most expensive in first cost, as is shown by the data obtained. Number of silos included, nine; average capacity, 288 tons; average cost, $\$ 577$, or $\$ 1.93$ per ton capacity.

The great difference in the cost of different silos of the same kind is apparent without much reflection. The range in cost per ton capacity in the 25 square wooden silos included in the preceding summary was from 70 cents to $\$ 3.60$. The former figure was obtained with a I44-ton silo, $20 \times 18 \times 20$ feet; and the latter with a I40-ton silo, built as follows: Dimensions, I4X28XI 8 feet; 2 XI2XI 8 feet studdings, set 12 inches apart ; two thicknesses of dimension boards inside, with paper between, sheeting outside with paper 
nailed on studding; cement floor. Particulars are lacking as regards the construction of the first silo, beyond its dimensions.

It may be in order to state, in comparing the average data for the cost of the different silo types, that the round silos were uniformly built better than the rectangular wooden silos included, and according to modern requirements, while many of the latter were old and of comparatively cheap construction, so that the figures cannot be taken to represent the relative value of rectangular and round silos built equally well.

A good many figures entering into the preceding summaries are doubtless somewhat too low, if all labor put on the silo is to be paid for, for in some cases the cost of work done by the farmers themselves was not figured in with other expenses. As most farmers would do some of the work themselves, the figures given may, however, be taken to represent the cash outlay in building silos. In a general way, it may be said that a silo can be built in the bay of a barn for less than 75 cents per ton capacity; a round or a good square or rectangular wooden silo for about $\$ 1.50$, and a stone or cement silo for about $\$ 2$ per ton capacity, all figures being subject to variations according to local prices of labor and materials.

Rennie, a Canadian writer, gives the following comparative figures as to cost of silos; Round stave silos, 75 cents per ton capacity; round wooden silos, \$I.25 and cement silos, \$I.25 to \$I.5O per ton capacity.

The cost of stave silos will of course vary with the kind of lumber used, cost of labor, and other expenses, as in case of other types of silos. It is evident that - stave silos can as a rule be built cheaper than other kinds of silos, both from the fact that less material is used in their construction, and because the labor bill is smaller. One of the first stave silos described, built in Ontario, Canada, cost $\$ 75.00$; capacity, I40 tons. 
Other and better built stave silos have been put up for $\$$ IOO for a roo-ton silo, and this may be considered an average price for such a silo, made of white pine, hemlock or any lumber that is cheapest in the particular locality where the silo is to be built. If built of Southern cypress, and complete with conical roof and doors, the price of stave silos will in the North come to about \$I.5O per ton capacity, small silos being a little dearer, and larger ones a little cheaper than this average figure.

\section{Estimating Materials and Cost of Silos.}

Several writers on silo construction have published bills of materials used in the construction of silos of moderate sizes of the following three types: Wisconsin Improved Silo, Modified Wisconsin Silo, and Stave Silo. Farmers contemplating building a silo, can use these estimates for figuring out the approximate cost of silos of the three kinds under his conditions as to cost of materials and labor. The estimates are made for silos built in the open, on level land. On hillsides deeper walls may be made to advantage, and where the silo is located within a building no roof will be needed. Consequently various factors may alter the application of these estimates, which are only offered as suggestive, with the hope they may prove helpful. The first three estimates of materials are published by Prof. Plumb, while the others have been furnished by Professors King and Withycombe.

Estimate of Materials for Wisconsin Improved Silos.

Size, 30 feet deep, 14 feet diameter. Capacity 90 tons.

Brick-3375 for foundation, I foot thick, 3 feet deep.

Studs -50 pieces $2 \times 4,16$ feet long.

Studs -50 pieces $2 \times 4,14$ feet long.

Flooring for doors - 32 feet, 4 matched.

Sheeting -3000 feet. $1 / 2$ inch, resawed from $2 \times 6-16$ foot plank sawed 3 times, dressed one side to uniform thickness, for inside lining of two layers. 
Lining-1500 feet of same for outside.

Tar building paper-200 yards, water-and acid proof.

Nails-200 lbs. 8-penny ; 200 1bs. 10-penny.

Spikes-20 1bs.

Rafters-22, 2x4, 10 feet long, for usual ridge roof.

Sheeting for roof--350 feet of 16 foot boards.

Shingles-3000.

Shingle nails-12 $1 \mathrm{bs}$.

Dormer window for filling through. Paint -7 gallons, providing two coats.

Cement -2 barrels, for cementing bottom.

Estimate of Material for a Modified Wisconsin Silo.

Same capacity as preceding.

Brick-350 for foundation, 8 in. wide, 5 in. thick.

Studs-50 pieces $2 \times 4,16 \mathrm{ft}$. long.

Studs-50 pieces $2 \times 4,14 \mathrm{ft}$. long.

Sheeting-3000 ft. $1 / 2$ in. resawed from $2 \times 6,16 \mathrm{ft}$. plank sawed three times, dressed to uniform thickness for inside lining of two layers.

Tar building paper 200 yards water-and acid proof.

Nails-150 1bs. 8 penny.

Spikes-12 1bs.

No outer siding, roof or floor is figured on or provided for in this construction.

\section{Estimate of Materials for Stave Silo.}

Size $12 \times 28 \mathrm{ft}$. capacity, 60 tons.

Brick-1800 for foundation, I foot thick, $2 \mathrm{ft}$. deep.

Staves-77 2x6, I6 ft. dressed 4 sides.

Staves-77 2x6, $12 \mathrm{ft}$. dressed 4 sides.

Rods-10, $191 / 2 \mathrm{ft}$. long $1 / 2$ in iron, with $5 / 8$ threaded ends and nuts.

Staples-2 gross $1 / 2 \times 2$ in.

Iron tighteners-20 holding ends of hoops.

Rafters-2 2x6 pieces, $14 \mathrm{ft}$. long for roof center.

Rafters-2 2x6 pieces $13 \mathrm{ft}$. long for roof, next center.

Side rafters $-48 \mathrm{ft} .2 \mathrm{x} 4$ pieces.

Roof sheeting-170 ft. common.

Tin sheeting-196 ft.

Cement for floor-2 bbls. 
Estimate of Materials for Wisconsin Improved Silo.

Size, $30 \mathrm{ft}$. deep, $20 \mathrm{ft}$. inside diameter, capacity, 200 tons.

Stone foundation, 7.5 perch.

Studs, $2 \times 4$, I 4 and I 6 feet, I,49 I feet.

Rafters, 2 X4, I 2 feet, 208 feet.

Roof boards, fencing, 500 feet.

Shingles, $6 \mathrm{M}$.

Siding, rabbeted, 2,660 feet.

Lining, fencing, ripped, 2,800 feet.

Tarred paper, $740 \mathrm{lbs}$.

Coal tar, I barrel.

Hardware, \$6.00.

Painting (60 cents per sqaure) \$1 3.20 .

Cementing bottom, $\$ 5.00$.

Carpenter labor (at $\$ 3$ per M. and board) $\$ 33.17$.

The estimated cost of the last silo is $\$ 246.39$; it is an outside, wholly independent structure, except connected with the barn in the manner shown in fig. 20 , with entrance and feeding chute toward the barn.

\section{Estimate of Materials for Stave Silo.}

$12 \mathrm{ft}$. in diameter, $24 \mathrm{ft}$. deep, capacity, 49 tons.

$12-3$ yards of rock or gravel.

4 barrels of sand.

1 barrel of cement.

$2260 \mathrm{ft}$. tongued and grooyed staves.

$72 \mathrm{ft} .3 \times 6,24 \mathrm{ft}$. door frames. 1 bs.

$358 \mathrm{ft}$. $5 / 8$ in. round iron for hoops and bolts, weight, 465

9 lugs.

54 nuts.

Preservative (\$1.50).

If the silo is constructed outside, materials for roof and painting are to be added to the preceding list.

Although most of the foregoing descriptions of stave silos do not mention tongued and grooved staves, the latest practices indicate that, if properly done, it is a 
decided advantage to have the staves matched, also slightly beveled. The silo made in this manner will not be so liable to go to pieces when empty. This is the chief objection to the stave silo, and numerous cases are on record where stave silos standing in exposed places have blown over when empty. It is recommended, therefore, that stave silos be attached, to the barn by means of a feeding chute, and in the case of high or exposed silos it is well to make use of guy rods or wires in addition. Indeed, some manufacturers of stave silos now recommend these on some of their silos, and make provision for them.

\section{Preservation of Silos.}

A silo building will not remain sound for many years unless special precautions are taken to preserve it. This holds good of all kinds of silos, but more espeoially of wooden ones, since a cement coating in a stone silo, even if only fairly well made, will better resist the action of the silage juices than the woodwork will be able to keep sound in the presence of moisture, high temperature, and an abundance of bacteriallife.

In case of wooden silos it is necessary to apply some material which will render the wood impervious to water, and preserve it from decay. A great variety of preparation have been recommended and used for this purpose. Coal tar has been applied by a large number of farmers, and has been found effective and durable. It may be put on either hot, alone or mixed with resin, or dissolved in gasoline. If it is to be applied hot, some of the oil contained in the tar must previously be burnt off. The tar is poured into an iron kettle, a handful of straw is ignited and thrown into the kettle, which will cause the oil to flash and burn off. The tar is sufficiently burnt when it will string out in fine threads, a foot or more in length, from a stick which has been thrust into the blazing kettle and 
afterward plunged into cold water. The fire is then put out by placing a tight cover over the kettle. The kettle must be kept over the fire until the silo lining has been gone over. A mop or a small whisk broom cut short, so it is stiff, may serve for putting on the tar.

Coal tar and gasoline have also been used by many with good success. About half a gallon of coal tar and two-thirds of a gallon of gasoline are mixed at a time, stirring it while it is being put on. Since gasoline is highly inflammable, care must be taken not to have any fire around when this mixture is applied. Asbestos paint has also been recommended for the preservation of silo walls, and would seem to be well adapted for this purpose.

Many silos are preserved by application of a mixture of equal parts of boiled linseed oil and black oil, or one part of the former to two of the latter. This mixture, applied every other year, before filling time, seems to preserve the lining perfectly. In building round silos, it is recommended to paint the boards with hot coal tar, and placing the painted sides face to face.

Manufacturers of stave silos and fixtures put up special prepartions for preserving the silos, which they send out with the staves. These are generally simply compounds similar to those given in the preceding, and are sold to customers at practically cost price.

Walls of wooden silos that have been preserved by one or the other of these methods will only keep sound and free from decay if the silos are built so as to insure good ventilation. Preservatives will not save a non-ventilated silo structure from decay.

Plastered wooden silos are preserved, as we have seen by applying a whitewash of pure cement as often as found necessary, which may be every two or three years. The same applies to stone and cement silos. The degree of moisture and acidity in the silage corn 
will doubtless determine how often the silo walls have to be gone over with a cement wash; a very acid silage, made from immature corn will be likely to soften the cement coating sooner than so-called sweet silage made from nearly mature corn.

A considerable number of wood silos are in use that were not treated on the inside with any preservative or paint and have stood very well. Indeed, some writers maintain that if the silo is well protected on the outside that a stave silo receives little if any benefit from inside coatings. 


\section{CHAPTER III.}

\section{SILAGE CROPS.}

Indian Corn. - Indian corn is, as has already been stated, the main silage crop in this country, and is likely to always remain so. Before explaining the filling of the silo and the making of silage, it will be well, therefore, to state briefly the main conditions which govern the production of a large crop of corn for the silo, and to examine which varieties of corn are best adapted for silage making.

Soils best adapted to corn culture and preparation of land. The soils best adapted to the culture of Indian corn are well-drained medium soils, loams, or sandy loams, in a good state of fertility. Corn will give best results coming after clover. The preparation of the land for growing corn is the same whether ear corn or forage is the object. Fall plowing is practiced by many successful corn growers. The seed is planted on carefully prepared ground at such a time as convenient and advisable. Other things being equal, the earlier the planting the better, after the danger of frost is ordinarily over. "The early crop may fail, but the late crop is almost sure to fail." After planting, the soil should be kept pulverized and thoroughly cultivated. Shallow cultivation will ordinarily give better results than deep cultivation, as the former method suffices to destroy the weeds and to preserve the soil moisture, which are the essential points sought in cultivating crops. The cultivation should be no more frequent than is necessary for the complete eradication of weeds. It has been found that the yield of corn may be decreased by too frequent, as well as by insufficient cultivation. The general rule may be 
given to cultivate as often, but no oftener, than is necessary to kill the weeds, or to keep the soil pulverized.

The cultivator may be started to advantage as soon as the young plants break through the surface, and the soil kept stirred and weeds detroyed, until cultivation is no longer practicable.

Varieties of corn for the silo. - The best corn for the silo, in any locality, is that variety which will be reasonably sure to mature before frost, and which produces a large amount of foliage and ears. The best varieties for the New England States, are the Leaming, Sanford, and Flint corn; for the Middle States, Leaming, White and Yellow Dent; in the Central and Western States, the Leaming, Sanford, Flint and White Dent will be apt to give the best results, while in the South, the Southern Horse Tooth, Mosby Prolific, and other large dent corns are preferred.

For Canada, Rennie gives, as the varieties best adapted tor the silo; for Northern Ontario, North Dakota and Compton's Early Flint ; for Central Ontario, larger and heavier-yielding varieties may be grown, viz., Mammoth Cuban and Wisconsin Earliest White Dent. It is useless to grow a variety for silage which will not be in a firm, dough state by the time the first frosts are likely to appear.

In the early stages of siloing corn in this country, the effort was to obtain an immense yield of fodder per acre, no matter whether the corn ripened or not. Large yields were, doubtless, often obtained with these big varieties, although it is uncertain that the actual yields ever came up to the claims made. Bailey's Mammoth Ensilage Corn, "if planted upon good corn land, in good condition, well matured, with proper cultivation," was guaranteed to produce from forty to to seventy-five tons of green fodder to the acre, " just right for ensilage." We now know that the immense 
Southern varieties of corn, when grown to an immature stage, as must necessarily be the case in Northern States, may contain less than ten per cent. of dry matter, the rest (more than nine-tenths of the total weight) being made up of water. This is certainly a remarkable fact, when we remember that skim-milk, even when obtained by the separator process, will contain nearly ten per cent. of solid matter.

In speaking of corn intended to. be cut for forage at an immature stage, Professor Robertson, of Canada, said at a Wisconsin Farmers' Institute, "Fodder corn sowed broadcast does not meet the needs of milking cows. Such a fodder is mainly a device of a thoughtless farmer to fool his cows into believing that they have been fed, when they have only been filled up." The same applies with equal strength to the use of large, immature Southern varieties for fodder, or for the silo, in Northern States.

In comparative variety tests with corn in the North, Southern varieties have usually been found to furnish larger quantities per acre of both green fodder and total dry matter in the fodder, than the smaller Northern varieties. As an average of seren culture trials, Professor Jordan thus obtained the following results at the Maine Station.

COMPaRative Yields OF SOUTHERN CORN AND MAINe Field CORN GROWN IN MAINE, I8S8-i893.

\begin{tabular}{|c|c|c|c|c|c|c|c|c|c|c|}
\hline & \multicolumn{5}{|c|}{ SOUTHERN CORN. } & \multicolumn{5}{|c|}{ Marine Field Corn. } \\
\hline & \multirow{2}{*}{$\begin{array}{c}\text { Green } \\
\text { Fod- } \\
\text { der. }\end{array}$} & \multicolumn{2}{|c|}{$\begin{array}{c}\text { Dry } \\
\text { Substance. }\end{array}$} & \multicolumn{2}{|c|}{$\begin{array}{c}\text { Digestible } \\
\text { Matter. }\end{array}$} & \multirow{2}{*}{$\begin{array}{c}\text { Green } \\
\text { Fod- } \\
\text { der. }\end{array}$} & \multicolumn{2}{|c|}{$\begin{array}{c}\text { Dry } \\
\text { Substance. }\end{array}$} & \multicolumn{2}{|c|}{$\begin{array}{l}\text { Digestible } \\
\text { Matter. }\end{array}$} \\
\hline & & $\begin{array}{l}\text { Per } \\
\text { Cent. }\end{array}$ & L bs. & $\begin{array}{l}\text { Per } \\
\text { Ct. }\end{array}$ & Lbs. & & $\begin{array}{c}\text { Per } \\
\text { Cent. }\end{array}$ & Lbs. & $\begin{array}{l}\text { Per } \\
\mathrm{Ct} .\end{array}$ & L, bs. \\
\hline $\begin{array}{l}\text { Maximum... } \\
\text { Minimum.... } \\
\text { Average.... }\end{array}$ & $\left|\begin{array}{l}46,340 \\
26,295 \\
34,761\end{array}\right|$ & \begin{tabular}{|l|}
16.58 \\
12,30 \\
14.50
\end{tabular} & $\begin{array}{l}6,237 \\
3,234 \\
5,036\end{array}$ & $\begin{array}{l}69 \\
61 \\
65\end{array}$ & $\begin{array}{l}3,923 \\
2,102 \\
3,251\end{array}$ & $\left|\begin{array}{r}29,400 \\
14,212 \\
22,269\end{array}\right|$ & $\left|\begin{array}{l}25.43 \\
13,55 \\
18.75\end{array}\right|$ & $\begin{array}{l}7.064 \\
2,415 \\
4,224\end{array}$ & $\begin{array}{l}78 \\
70 \\
72\end{array}$ & $\begin{array}{l}4,945 \\
1,715 \\
3,076\end{array}$ \\
\hline
\end{tabular}


The average percentage digestibility of the dry substance is 65 per cent for the Southern corn, and 72 per cent for the Maine field corn, all the results obtained for the former varieties being lower than those obtained for the latter. While the general result for the five years, so far as the yield of digestible matter is concerned, is slightly in favor of the Southern varieties, the fact should not be lost sight of that an average of $6 \frac{1}{4}$ tons more of material has annually to be handled over several times, in case of these varieties of corn, in order to gain 75 pounds more of digestible matter per acre; we, therefore, conclude that the smaller, less watery, variety of corn really proved the more profitable.

At other Northern stations similar results, or results more favorable to the Northern varieties, have been obtained, showing that the modern practice of growing only such corn for the silo as will mature in the particular locality of each farmer, is borne out by the results of careful culture tests.

Time of cutting corn for the silo. In order to determine at what stage of growth corn had better be cut when intended for the silo, it is necessary to ascertain the amounts of food materials which the corn plant contains at the different stages, and the proportion of different ingredients at each stage. From careful and exhaustive studies of the changes occurring in the composition of the corn plant, which have been conducted both in this country and abroad, we know that as the corn approaches maturity the nitrogenous or flesh-forming substances decrease in proportion to the other components, while the non-nitrogenous components, especially starch (see Glossary), increase very markedly; this increase continues until the crop is nearly mature, so long as the leaves are still green. Several experiment stations have made investigations in regard to this point. As an illustration we give below data obtained by Prof. Ladd, in an investiga- 
tion in which fodder corn was cut and analyzed at five different stages of growth, from full tasseling to maturity.

CHEMICAI, CHANGES IN THE CORN CROP.

\begin{tabular}{|c|c|c|c|c|c|}
\hline YIELD PER ACRE. & $\begin{array}{c}\text { Tas- } \\
\text { seled, } \\
\text { July } 30\end{array}$ & $\begin{array}{l}\text { Silked } \\
\text { Aug. } 9 .\end{array}$ & $\begin{array}{l}\text { Milk, } \\
\text { Aug. } 21\end{array}$ & $\begin{array}{l}\text { Glazed } \\
\text { Sept. } 7 .\end{array}$ & $\begin{array}{c}\text { Ripe } \\
\text { Sept.23 }\end{array}$ \\
\hline Grog WViot & Pounds & Pounds & Pounds & Pounds & Pounds \\
\hline Water in the Crop..... & $\begin{array}{l}180+5 \\
16426\end{array}$ & 25845 & 27957 & 25093 & 20542 \\
\hline Dry Matter............ & 1619 & 3078 & 4643 & 7202 & 7918 \\
\hline Ash $\ldots \ldots \ldots \ldots \ldots$ & 138.9 & 201.3 & 2322 & 302.5 & 364.2 \\
\hline Crude Protein............ & 239.8 & 4368 & 478.7 & 643.9 & 6778 \\
\hline 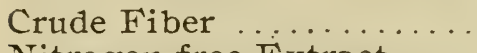 & 5142 & 872.9 & 1262.0 & 2755.9 & 17340 \\
\hline $\begin{array}{l}\text { Nitrogen-free Extract } \\
\text { (starch, sugar, etc) }\end{array}$ & 6539 & 13993 & 244 & 42398 & 4827 \\
\hline Crude Fat $\ldots \ldots \ldots \ldots$ & 72.2 & 167.8 & 228.9 & 260.0 & 314.3 \\
\hline
\end{tabular}

The data given above show how rapidly the yield of food materials increases with the advancing age of the corn, and also that the increase during the later stages of growth comes largely on the nitrogen-free extract (starch, sugar, etc.).

The results as to this point obtained at several experiment stations have been summarized and are given in the following table, showing the increase in food ingredients during the stages previous to maturity.

We thus find that the largest amount of food materials in the corn crop is not obtained until the corn is well ripened. When a corn plant has reached its total growth in height it has, as shown by the results given in the last table, attained only one-third to onehalf of the weight of dry matter it will gain if left to maturity; hence we see the wisdom of postponing cutting the corn for the silo, as in general for forage purposes, until rather late in the season, when it can be done without danger of frost.

The table given in the.preceding, and our discussion 
INCREASE IN FOOD INGREDIENTS FROM TASSELING TO MATURITY.

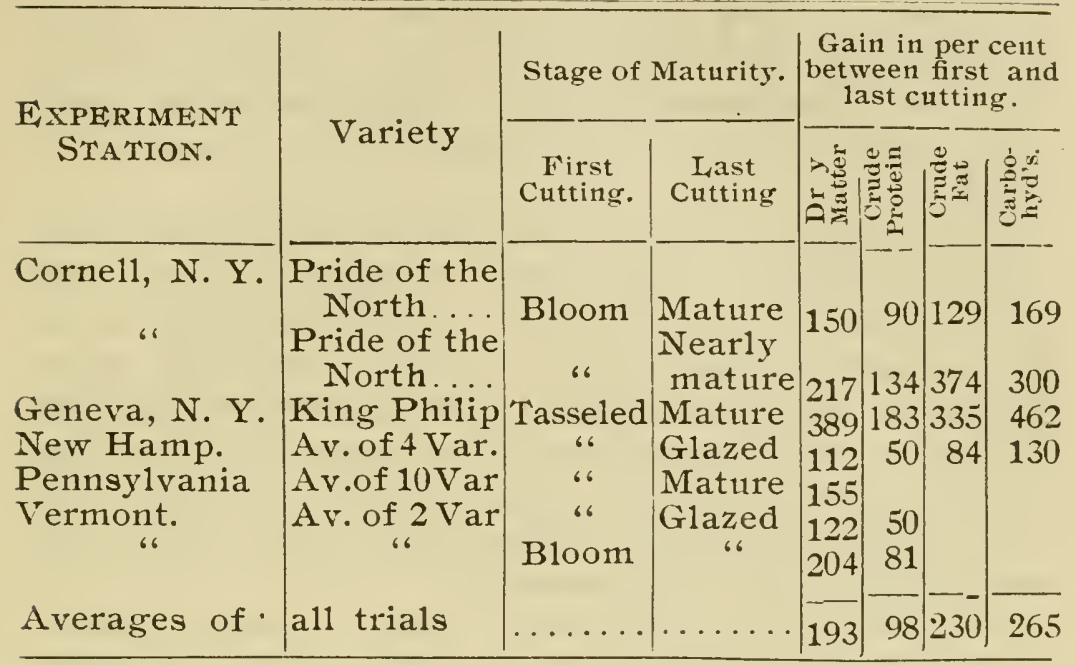

so far, have taken into account only the total, and not the digestible components of the corn.

It has been found through careful digestion trials that older plants are somewhat less digestible than young plants. There is, however, no such difference in the digestibility of the total dry matter or its components as is found in the total quantities obtained from plants at the different stages of growth, and the total yields of digestible matter in the corn will therefore be greater at maturity, or directly before this time, than at any earlier stage of growth. Hence we find that the general practice of cutting corn for the silo at the time when the corn is in the roasting-ear stage, when the kernels have become rather firm, and are dented or beginning to glaze, is good science and in accord with our best knowledge on the subject.

Other reasons why cutting at a late period of growth is preferable in siloing corn are found in the fact that the quality of the silage made from such corn is greatly better than that obtained from green 
immature corn, and in the fact that the sugar is most abundant in the corn plant in the early stages of ear development, but the loss of non-nitrogenous components in the silo falls first of all on the sugar; hence it is the best policy to postpone cutting until the grain is full-size and the sugar has largely been changed to starch.

It does not do, however, as related under Uniformity in the first chapter to delay the cutting so long that the corn plant becomes too dry, for the reasons stated. Silage does not spoil when too wet, but will mold if too dry. Experience will be the best guide, but the foregoing pages should enable the reader to form the right idea as to time for filling, which to secure the best results, is nearly as important as to have material with which to fill the silo.

Methods of Planting Corn. When the corn crop is intended for the silo, it should be planted somewhat closer than is ordinarily the case when the production of a large crop of ear corn is the primary object sought. Thin seeding favors the development of welldeveloped, strong plants, but not the production of a large amount of green forage. The number of plants which can be brought to perfect development on a certain piece of land depends upon the state of fertility of the land, the character of the season, especially whether it is a wet or a dry season, as well as on other factors, hence no absolute rule can be given as to the best thickness of planting corn for the silo. Numerous - experiments conducted in different parts of the country have shown, however, that the largest quantities of green fodder per acre can ordinarily be obtained by planting the corn in hills three or even two feet apart, or in drills three or four feet apart, with plants six or eight inches apart in the row.

It makes little if any difference, so far as the yield obtained is concerned, whether the corn be planted in hills or in drills, when the land is kept free from weeds 
in both cases, but it facilitates the cutting considerably to plant the corn in drills if this is done by means of a corn harvester or sled cutter; as is now generally the case. The yield seems more dependent on the number of plants growing on a certain area of land than on the arrangements of planting the corn. Hills four feet each way, with four stalks to the hill, with thus usually give about the same yields as hills two feet apart, with two stalks in the hill, or drills four feet apart, with stalks one foot apart in the row, etc. The question of planting corn in hills or in drills is therefore largely one of greater or less labor in keeping the land free from weeds by the two methods. This will depend on the character of the land; where the land is uneven, and check-rowing of the corn difficult, or when the land is free from weeds, drill planting is preferable, while, conversely, on fields where this can be done, the corn may more easily and cheaply be kept free from weeds if planted in hills and check-rowed. Since one of the advantages of the silo is the economical production and preservation of a good quality of feed, the economy and certainty in caring for the growing crop is of considerable importance, and generally, planting in hills not too far apart will be found to facilitate this, especially during wet seasons.

Corn is planted in hills or in drills, and not broadcast, whether intended for the silo, or for production of ear corn; when sown broadcast, the corn cannot be kept free from weeds, except by hand labor. More seed is moreover required, the plants shade each other and will therefore not reach full development, from lack of sufficient sunshine and moisture, and a less amount of available food constituents per acre will be produced.

\section{OTher Sillage Crops.}

Clover. Clover is second to Indian corn in importance as a silage crop. We are but beginning to 
appreciate the value of clover in modern agriculture. It has been shown that the legumes, the family to which clover belongs, are the only common forage plants able to convert the free nitrogen of the air into compounds that may be utilized for the nutrition of animals. Clover and other legunies, therefore, draw largely on the air for the most expensive and valuable fertilizing ingredient, nitrogen, and for this reason, as well as on account of their deep roots, which bring fertilizing elements up near the surface, they enrich the land upon which they grow. Being a more nitrogenous fecd than corn or the grasses, clover supplies a good deai of the protein compounds required by farm animals for the maintenance of their bodies and for the production of milk, wool, or meat. By feeding clover, a smaller purchase of high-priced concentrated feed stuffs, like flour-mill or oil-mill refuse products, is therefore rendered necessary than when corn is fed; on account of its high fertilizing value it furthermore enables the farmer feeding it to maintain the fertility of his land.

When properly made, clover silage is an ideal feed for nearly all kinds of stock. Aside from its higher protein content it has an advantage over corn silage in point of lower cost of production. A Wisconsin dairy farmer who has siloed large quantities of cloverestimates the cost of one ton of clover silage at 70 cents to $\$ I$, against $\$ I$ to $\$ I .25$ per ton of corn silage. His average yields per acre of green clover are about twelve tons.

Clover silage is superior to clover hay on account of its succulence and greater palatability, as well as its higher feeding value. The last-mentioned point is mainly due to the fact that all the parts of the clover plant are preserved in the silo, with a small unavoidable loss in fermentation, while in hay-making, leaves and tender parts, which contain about two-thirds of 
the protein compounds, are often largely lost by abrasion.

Clover may easily and cheaply be placed in a modern silo and preserved in a perfect condition. The failures reported in the early stages of silo filling were largely due to a faulty construction of the silo. Clover does not pack as well as the heavy green corn, and therefore requires to be cut and weighted, or calls for greater depth in the silo, in order that the air may be sufficiently excluded.

When to Cut Clover for the Silo. The yield of food materials obtained from clover at different stages of growth has been studied by a number of scientists. The following table giving the results of an investigation conducted by Professor Atwater will show the total quantities of food materials secured at four different stages of growth of red clover.

YIELD PER ACRE OF RED ClOVER-IN POUNDS.

\begin{tabular}{|c|c|c|c|c|c|c|c|}
\hline $\begin{array}{l}\text { Stage of } \\
\text { CutTing. }\end{array}$ & $\begin{array}{c}\text { Green } \\
\text { Weight. }\end{array}$ & $\begin{array}{c}\text { Dry } \\
\text { Matter. }\end{array}$ & $\left|\begin{array}{c}\text { Crude } \\
\text { Protein }\end{array}\right|$ & $\begin{array}{l}\text { Crude } \\
\text { Fiber. }\end{array}$ & $\mid \begin{array}{c}\text { N-free } \\
\text { Extract }\end{array}$ & $\begin{array}{c}\text { Crude } \\
\text { Fat. }\end{array}$ & Ash \\
\hline Just before & & & & & & & \\
\hline bloom..... & 3,570 & 1,385 & 198 & 384 & 664 & 24 & 115 \\
\hline $\begin{array}{l}\text { Full bloom. } \\
\text { Nearly out of }\end{array}$ & 2,650 & 1,401 & 189 & 390 & 682 & 33 & 107 \\
\hline bloom. .... & 4,960 & 1,750 & 230 & 523 & 837 & 31 & 129 \\
\hline Nearly ripe. & 3,910 & 1,523 & 158 & 484 & 746 & 36 & 99 \\
\hline
\end{tabular}

Professor Hunt obtained 3,600 pounds of hay per acre from clover cut in full bloom, and 3,260 pounds when three-fourths of the heads were dead. The yields of dry matter: in the two cases were 2,526 pounds, and 2,427 pounds respectively. All components, except crude fibre (see Glossary), yielded less per acre in the second cutting. Jordan found the same result, comparing the yields and composition of clover cut when in bloom, some heads dead, and heads all dead, the earliest cutting giving the maximum 
yield of dry matter, and of all components except crude fibre.

The common practice of farmers is to cut clover for the silo when in full bloom, or when the first single heads are beginning to wilt, that is, when right for hay making, and we notice that the teachings of the investigations made are in conformity with this practice.

Alfalfa (lucern) is the great, coarse forage plant of the West, and during late years, it is being grown considerably in the Northern and Central States. In irrigated districts it will yield more food materials per acre of land than perhaps any other crop. Four to five cuttings, each yielding a ton to a ton and a half of hay, are common in these regions, and the yields obtained are often much higher. In humid regions three cuttings may ordinarily be obtained, each of one to one and a half tons of hay.

While the large bulk of the crop is cured as hay, alfalfa is also of considerable importance as a silage crop in dairy sections of the Western States. As with red clover, reports of failure in siloing alfalfa are on record, but first-class alfalfa silage can be readily made in deep, modern silos, when the crop is cut when in full bloom, and the plants are not allowed to wilt much before being run through a cutter and siloed. In the opinion of dairymen who have had large experience in siloing alfalfa, sweet alfalfa silage is more easily made than good alfalfa hay.

What has been said in regard to the siloing of clover refers to alfalfa as well. Alfalfa silage compares favorably with clover silage, both in chemical composition and in feeding value. It is richer in flesh-forming substances (protein) than clover silage, or any other kind of silage, and makes a most valuable feed for farm animals, especially young stock and dairy cows.

Cow peas are to the South what alfalfa is to the 
West, and when properly handled makes excellent and most valuable silage. The cow peas are sown early in the season, either broadcast, about $\mathrm{I} / 2$ bushels to the acre and turned under with a one-horse turning plow, or drilled in rows about two feet apart. They are cut with a mower when one-half or more of the peas on the vines are fully ripe, and are immediately raked in winrows and hauled to the silo, where they are run through a feed cutter and cut into inch lengths.

Cow-pea silage is greatly relished by farm animals after they once become accustomed to its peculiar flavor; farmers who have had considerable practical experience in feeding this silage are of the opinion that cow-pea silage has no equal for cows and sheep. It is also a good hog food, and for all these animals is considered greatly superior to pea-vine hay. In feeding experiments at a Delaware experiment station six pounds of pea-vine silage fully took the place of one pound of wheat bran, and the product of one acre was found equivalent to two tons of bran.

Instead of placing only cow peas in the silo, alternate loads of cow peas and corn may be cut and filled into the silo, which will make a very satisfactory mixed silage. A modification of this practice is known as Getty's method, in which corn and cow peas are grown in alternate rows, and harvested together with a corn harvester. Corn for this combination crop is preferably a large Southern variety, drilled in rows $4 \frac{1}{2}$ feet apart, with stalks 9 to 16 inches apart in the row. Whippoorwill peas are planted in drills close to the rows of corn when this is about six inches high, and has been cultivated once. The crop is cut when the corn is beginning to glaze, and when three-fourths of the pea pods are ripe.

The corn and peas are tied into bundles and these run through the silage cutter. The cut corn and peas are carefully levelled off and trampled down in the silo, and about a foot cover of green corn, straw or 
cotton-seed hulls placed on top of the siloed mass. As in case of all legumes, it is safest to wet the cover thoroughly with at least two gallons of water per square foot of surface. This will seal the siloed mass thoroughly and will prevent the air from working in from the surface and spoiling considerable of the silage on top.

A similar effort of combining several feeds for the silo is found in the so-called Robertson Ensilage Mixture for the silo, named after Prof. Robertson in Canada; this is made up of cut Indian corn, sunflower seed heads, and horse beans in the proportion of I acre corn, $1 / 2$ acre horse beans, and $1 / 4$ acre şunflowers. The principle back of the practice is to furnish a feed richer in protein substances than corn, and thus avoid the purchase of large quantities of expensive protein foods like bran, oil meal, etc. Feeding experiments conducted with the Robertson Silage Mixture for cows at several experiment stations have given very satisfactory results, and have shown that this silage mixture can be partly substituted for the grain ration of milch cows without causing loss of flesh or lessening the production of milk or fat. Fifteen pounds of this silage may be considered equivalent to three or four pounds of grain feeds. The practice has not, however, been adopted to any great extent, so far as is known, owing to the difficulty of securing a good quality of silage from the mixture and of growing the horsebeans successfully.

Soja beans (soy beans) are another valuable silage crop. According to the U. S. Department of Agriculture the soy bean is highly nutritive, gives a heavy yield, and is easily cultivated. The vigorous late varieties are well adapted for silage. The crop is frequently siloed with corn ( 2 parts of the latter to I of the former), and like other legumes it improves the silage by tending to counteract the acid reaction of corn silage. Of other Southern crops that are used 
for silage crops may be mentioned Kaffir corn, chicken corn and teosinte.

Sorgum is sometimes siloed in the Western and Middle States. It is sown in drills, $31 / 2$ inches apart, with a stalk every six to ten inches in the row, and is cut when the kernels are in the dough stage, or before. According to Shelton, the medium-growing saccharine and non-saccharine sorghums are all excellent for silage. The sorghums are less liable to damage by insects than corn, and they remain green far into the fall, so that the work of filling the silo may be carried on long after the corn is ripe and the stalks all dried up. The yield per acre of green sorghum will often reach 20 tons, or one-half as much again as a good crop of corn. These considerations lead Professor Shelton to pronounce sorghum greatly superior to corn as silage materials, in Kansas, and generally throughout the Central Western States. The Ottawa (Can.) states that sorghum, where it can be grown makes an excellent crop for silage. It needs to be cut, the best length, as in the case of corn being three-quarters or an inch long, or less.

Miscellaneous Silage Crops. In Northern Europe, especially in England, and in the Scandinavian countries, meadow grass and after-math (rowen) are usually siloed; in England, at the present time, large$1 \mathrm{y}$ in stacks.

In districts near sugar beet factories, where sugarbeet pulp can be obtained in large quantities and at a low cost, stock feeders and dairymen have a most valuable aid in preserving the pulp in the silo. As the pulp is taken from the factory it contains about 90 per cent of water; it packs well in the silo, being heavy, finely divided and homogeneous, and a more shallow silo can therefore be safely used in making pulp silage than is required in siloing corn, and especially clover and other crops of similar character. If pulp is siloed with other fodder crops, it is pre- 
ferably placed uppermost, for the reason stated. Beet tops and pulp are often siloed in alternate layers in pits 3 to 4 feet deep, and covered with boards and a layer of dirt. Beet pulp can also be successfully placed in any modern deep silo, and is preferably siloed in such silos as there will then be much smaller losses of food materials than in case of shallow silos or trenches in the field.

Beet pulp silage is relatively rich in protein and low in ash and carbohydrates (nutr. ratio $\mathrm{I}: 5.7$; see Glossary). Its feeding value is equal to about half that of corn silage.

Occasional mention has furthermore been made in the agricultural literature of the siloing of a large number of plants, or products, like vetches, small grains (cut green), cabbage leaves, sugar beets, potatoes, potato leaves, turnips, brewers' grains, apple pomace, refuse from corn and pea canning factories; twigs, and leaves, and hop vines; even fern (brake), thistles, and ordinary weeds have been made into silage, and used with more or less success as foods for farm animals.

At a recent convention of the Cal. Dairy Association, the president, Mr. A. P. Martin, stated that the best silage he ever made, besides corn, was made of weeds. A piece of wheat which was sowed early, was drowned out, and the field came up with tar weed and sorrel. This was made into silage, and when fed to milch cows, produced most satisfactory results.

Alvord says that a silo may be found a handy and profitable thing to have on a farm even if silage crops are not regularly raised to fill it. There are always waste products, green or half-dry, with coarse materials like swale hay, that are generally used for compost or bedding, which may be made into palatable silage. A mixture, in equal parts, of rag-weed, swamp grass or swale hay, old corn stalks or straw, and second-crop green clover, nearly three-fourths of 
which would otherwise be almost useless, will make a superior silage, surprising to those who have never tried it.

The following description of the contents filled into a New York silo, which was used as a sort of catchall, is given by the same writer: I, I 8 in. deep of green oats; 2, 6 in. of red clover; 3, 6 in. of Canada field peas; 4,3 in. of brewers' grains; 5,2 feet of whole corn plants, sowed broadcast, and more ragweed than corn; 6, 5 in. of second-crop grass; 7, I 2 in. of sorghum: 8, a lot immature corn cut in short lengths. The silage came out pretty acid, but made good forage, and was all eaten up clean. Damaged crops like frosted beets, potatoes, cabbages, etc.; rutabages which showed signs of decay, and clover that could not be made into hay because of rain, may all be placed in a silo and thus made to contribute to the food supply on the farm.

A peculiar use of the silo is reported from California, viz., for rendering foxtail in alfalfa fields hatmless in feeding cattle. The foxtail which almost takes the first crop of alfalfa in many parts of California, is a nutritious grass, but on account of its beards, is dangerous to feed. By siloing the crop the grass is said to be rendered perfectly harmless; the alfalfa-foxtail silage thus obtained is eaten by stock with great relish and without any injurious effects (Wall). 


\section{CHAP'TER IV. \\ HOW TO MAKE SILAGE. \\ Filling the Silo.}

A. Indian Corn. As previousiy stated, corn should be left in the field before cutting until it has passed through the dough stage i. e., when the kernels are well dented, or glazed, in case of flint varieties. Where very large silos are filled, and in cases of extreme dry weather when the corn is fast drying up, it will be well to begin filling the silo a little before it has reached this stage, as the greater portion of the corn would otherwise be apt to be too dry. There is, however, less danger in this respect now than formerly, on account of our modern deep silos, and because we have found that water applied directly to the fodder in the silo acts in the same way as water in the fodder, and keeps the fermentations in the silo in check and in the right track.

Cutting the Corn in the Field. The cutting of corn for the silo is usually on small farms done by hand by means of a corn knife. Many farmers bave been using self-raking and binding corn harvesters for this purpose, while others report good success with a sled or platform cutter. If the corn stands up well, and is not of a very large variety, the end sought may be reached in a satisfactory manner by either of these methods. If, on the other hand, much of the corn is down, hand cutting is to be preferred. A number of different makes of corn harvesters and corn cutters are now on the market; and, it is very likely that handcutting of fodder corn will be largely done away with in years to come, at least on large farms, indeed, it looks as if the day of the corn knife was passing away, 
and as if this implement will soon be relegated to obscurity with the sickle of our fathers' time.

If a corn harvester is used, it will be found to be a great advantage to have the bundles made what seems rather small. It will take a little more twine, but the loaders, the haulers, the unloaders, and even the Silage Cutter itself will handle much more corn in a day if the bundles are small and light, and it will be found to be economy to see that this is done.

A platform cutter, which was used with great success, is described by a veteran Wisconsin dairyman, the late Mr. Charles R. Beach.

"We use two wagons, with platforms built upon two timbers, eighteen feet long, suspended beneath the axles. These platforms are about eighteen inches from the ground and are seven feet wide. The cuttingknife is fastened upon a small removable platform, two feet by about three and one-half feet, which is attached to the side of the large platform, and is about six or eight inches lower. One row is cut at a time, the knife striking the corn at an angle of about fortyfive degrees. One man kneels on the small platform and takes the corn with his arm; two or three men stand upon the wagon, and as soon as he has gotten an armful, the men, each in turn, take it from him and pile it on the wagon. If the rows are long enough a load of one and one-half to two tons can be cut and loaded on in about eight to ten minntes. The small platform is detached from the wagon, the load driven to the silo, the platform attached to the other wagon, and another load is cut and loaded. None of the corn reaches the ground; no bending down to pick up. One team will draw men, cutter, and load, and I do not now well see how the method could be improved. With a steam engine, a large cutter, two teams and wagons, and ten men, we filled our silo $22 \times 24 \times 18$ feet ( 190 tons), fast, in less than two days."

Professor Georgeson, has described a one-horse 
sledge-cutter which has given better satisfaction than any fodder-cutter tried at the Kansas Experiment Station. It is provided with two knives, which are hinged to the body of the sled, and can be folded in on the sled when not in use. It has been improved and made easier to pull by providing it with four low and broad cast-iron wheels. It is pulled by a single horse and cuts two rows at a time. Two men stand upon the cutter, each facing a row; as the corn is cut they gather it into armfuls, which they drop into heaps on the ground. A wagon with a low, broad rack follows, on which the corn is loaded and hauled to the silo.

Similar corn cutters have been made by various manufacturers of late years and have proved quite satisfactory, although they require more hand labor than the corn harvesters and do not leave the corn tied up and in as convenient shape for loading on the wagons as these do. It is also necessary to use care with the sledge type of corn cutter, as numerous cases are on record where both men and horses have been injured by getting in front of the knives, which project from the sides.

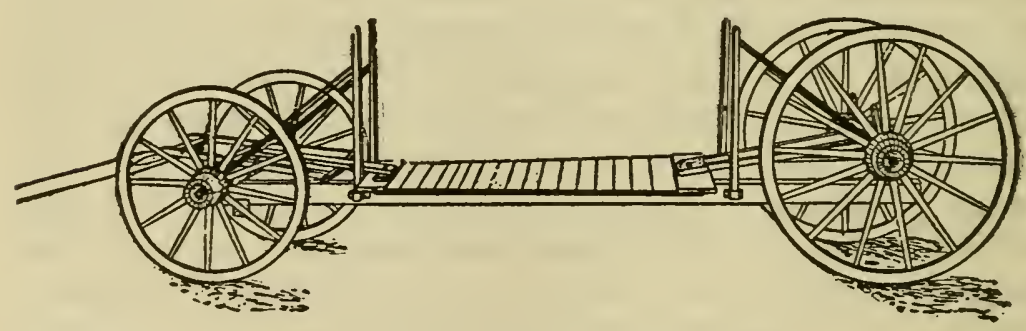

Fig. 27. Low-down Rack for hauling fodder corn.

A low-down rack for hauling the corn from the field is shown in the accompanying illustration (Fig. 27). It has been used for some years past at the Wisconsin Station, and is a great convenience in handling corn, saving both labor and time. These, racks not 
only dispense with a man upon the wagon when loading, but they materially lessen the labor of the man who takes the corn from the ground, for it is only the top of the load which needs to be raised shoulder-high; again, when it comes to unloading, the man can stand on the floor or ground and simply draw the corn toward him and lay it upon the table of the cutter, without stooping over and without raising the corn up to again throw it down. A plank that can easily be hitched on behind the truck will prove convenient for loading, so that the loader can pick up his armful and, walking up the plank, can drop it without much exertion.

If wilted fodder corn is to be siloed it should be shocked in the field to protect it as much as possible from rain before hauling it to the cutter.

SILOING CORN, "EARS AND ALL."

The best practice in putting corn into the silo, is to silo the corn plant " ears and all," without previously husking it. If the ear corn is not needed for hogs and horses, or for seed purposes, this practice is in the line of economy, as it saves the expense of husking, cribbing, shelling, and grinding the ear corn. The possible loss of food materials sustained in siloing the ear corn speaks against the practice, but this is very small, and more than couterbalanced by the advantages gained by this method of procedure. In proof of this statement we will refer to an extended feeding trial with milch cows, conducted by Professor Woll at the Wisconsin Station in I89I.

Corresponding rows of a large corn field were siloed, "ears and all," and without ears, the ears belonging to the latter lot being carefully saved and air-dried. The total yield of silage with ears in it (whole-corn silage) was 56,459 pounds; of silage without ears (stover silage) 34,496 pounds and of ear corn, IO, 5 I I pounds. The dry matter content of the lots obtained 
by the two methods of treatment was, in whole-corn silage, I 9,950 pounds; in stover silage 9,484 pounds; and in ear corn, 9, I 22 pounds, or 18,606 pounds of dry matter in the stover silage and ear corn combined. This shows a loss of 1,344 pounds of dry matter, or nearly 7 per cent, sustained by handling the fodder and ear corn separately instead of siloing the corn "ears and all."

In feeding the two kinds of silage against each other, adding the dry ear corn to the stover silage, it was found that seventeen tons of whole-corn silage fed to sixteen cows produced somewhat better results than fourteen tons of stover silage, and more than two tons of dry ear corn, both kinds of silage having been supplemented by the same quantities of hay and grain feed. The yield of milk from the corvs was 4 per cent higher on the whole corn silage ration than on the stover silage ration, and the yield of fat was 6.9 per cent higher on the same ration. It would seem then that the cheapest and best way of preserving the corn crop for feeding purposes, at least in case of milch cows, is to fill it directly into the silo; the greater portion of the corn may be cut and siloed when the corn is in the roasting-ear stage, and the corn plat which is to furnish ear corn may be left in the field until the corn is fully matured, when it may be husked, and the stalks and leaves may be filled into the silo on top of the corn siloed "ears and all." This will then need some heavy weighting or one or two applications of water on top of the corn, to insure a good quality of silage from the rather dry stalks. (See page r33.)

An experinient similar to the preceding one, conducted at the Vermont Station, in which the product from six acres of land was fed to dairy cows, gave similar results. We are justified in concluding, therefore, that husking, shelling, and grinding the corn (processes that may cost more than a quarter of the 
market value of the meal) are labor and expense more than wasted, since the cows do better on the corn siloed "ears and all" than on that siloed after the ears were picked off and fed ground with it.

\section{THE FILLING PROCESS.}

The corn, having been hauled from the field to the silo, has still to be reduced to a fine, homogeneous mass, convenient for feeding and economical as far as utilization of the silage for feed.

In order to do this, the whole of the corn, ears and all, may be run through an "Ohio" Ensilage Cutter.

The corn is unloaded on the table of the cutter and run through the cutter, after which the carrier or blower elevates it to the silo window and delivers it into the silo. The length of cutting practiced differs somewhat with different farmers, and with the variety of corn to be siloed. The general practice is to cut the corn in one-half to one inch lengths. The corn will pack better in the silo the finer it is cut, and cattle will eat the larger varieties cleaner if cut fine, and the majority of farmers filling silos practice cutting corn rather fine for the silo.

The carriers should deliver the corn as nearly in the middle of the silo as possible; by means of a chute attached to the carrier, the cut corn may be delivered to any part of the silo desired, and the labor of distributing and leveling the corn thus facilitated. A simple method of distribution is to attach to the blower a tube made of a number of sacks sewed together with bottoms out, through which the silage will then descend. Such a device does not last very long, however, as the cut corn soon wears holes through the sacks.

If the corn is siloed "ears and all," it is necessary to keep a man or a boy in the silo while it is being filled, to level the surface and tramp down the sides and corners; if left to itself, the heavier pieces of ears will 
be thrown farthest away and the light leaves and tops will all come nearest the discharge; as a result the corn will not settle evenly, and the different layers of silage will have a different feeding value. To assist in the distribution of the corn, a pyramidal box may be hung in front and below the top of the carrier; this may be made about three feet square at the base and tapering to a point, at which a rope is attached for hanging to rafters. The falling mass of cut corn will strike the top of the box and be divided so as to distribute to all parts of the silo. Another simple device is to place a board vertically, or nearly so, in front of the top of the carrier, against which the cut corn will strike. These devices must be nicely adjusted as to position, however, or they will not be of much advantage.

\section{The Proper Distribution of the Cut Material in the Silo.}

The proper distribution of the cut corn after it has been elevated or blown into the silo is a matter which should have proper attention at the time of filling. If the cut material is allowed to drop all in one place and then have no further attention the constant falling of the material in one place will tend to make that portion solid while the outside will not be so, and besides the pieces of ears and heavier portions will continually roll to the outside. As a result the silage cannot settle evenly, and good results will not follow. As the filling progresses, the cut material should be leveled off and the common and most successful practice is to keep the material higher at the sides than at the centre and do all the tramping at and close to the sides, where the friction of the walls tends to prevent as rapid settling as takes place at the centre. For this reason, no tramping, or at least, as little as possible, should be done, except close to the walls. In the modern deep silos, the weight of the silage ac- 
complishes more than would any amount of tramping, and all that is necessary, is to see that the cut material is rather evenly distributed, for better results in feeding, and to assist the settling by some tramping at the sides.

\section{Size of Cutter and Power Required.}

The "Ohio" Cutters are made in a variety of sizes, suited to all requirements.

The cutter used in filling the silo should have ample capacity to give satisfaction and do the work rapidly; a rather large cutter is therefore better than a cutter that is barely large enough. The size required depends on the rapidity with which it is desired to fill the silo and on the power at hand. Where a steam engine is available it is the cheapest power for filling a large silo, as the work can then be finished in a few days. For small farms and silos, where an engine is not to be had, a two or three-horse tread-power may be used, but it will be found that the work of filling will progress much more slowly than when steam power, such as is suitable for threshing, is used. The filling may be done as rapidly as possible, or may be done slowly, and no harm will result if, for any reason, the work be interrupted for some time. More silage can be put into a silo with slow, than with rapid filling. If the farmer owns his own machine, he can, of course, fill his silo, and then refill after the silage has settled, so that the silo will be nearly full after all settling has taken place.

If, however, the farmer must depend on hiring an outfit, he will wish to do the filling as rapidly as possible, as a matter of economy. It is, therefore, desirable for the farmer to own his own machine, and that being the case, a smaller machine will suffice; wherein if the machine be hired the largest possible capacity will be desired.

This has created a demand for various sizes of 
cutters, and to meet this demand, the "Ohio" Ensilage Cutters are made in six sizes, with knives eleven to twenty four inches long, and with Metal Bucket Elevators, or Blower Elevators, as desired, adaptable to any height of silo. The traveling feed table, as supplied on the "Ohio" Cutters is a valuable feature, and practically does away with the labor of feeding the heavy green corn into the feed rolls, besides increasing the capacity of the machines about one-third, on account of its being so much easier to keep the feed rolls supplied.

The Metal Bucket Elevator, which delivers the cut silage corn into the silo through a window or opening at the top, must be longer than the silo is high as it is necessary to run the carrier at somewhat of an angle, (see illustration, Fig. 28). The length of the carrier required may be obtained by adding about 40 percent. to the perpendicular height from the ground to the window; thus, for a $20 \mathrm{ft}$. silo a $28 \mathrm{ft}$. carrier is required, and for a $30 \mathrm{ft}$. silo, about $42 \mathrm{ft}$. of carrier will be necessary.

The Metal Bucket Elevators for the "Ohio" Cutters are made both straight away and with swivel base, which enables the operator to set the cutter in the desired position, and as the swivel base gives the carrier a range of adjustment extending over nearly a half circle, the carrier can be run directly to the window, or in the case of two silos setting side by side, both can be filled with one setting of the cutter.

The No. I3 "Ohio" Silage Cutter, 'the number of the machine indicates the length of knives and width of throat), has a capacity of 8 to 12 tons of green corn per hour, and requires 4 to 6 horse-power to run it to full capacity, although it can be operated successfully with less power, by feeding in proportion to the power at hand. The 16 and 18 inch and larger sizes of "Ohio" Cutters have correspondingly larger capacities, and in the case of the larger sizes the amount that can be cut 


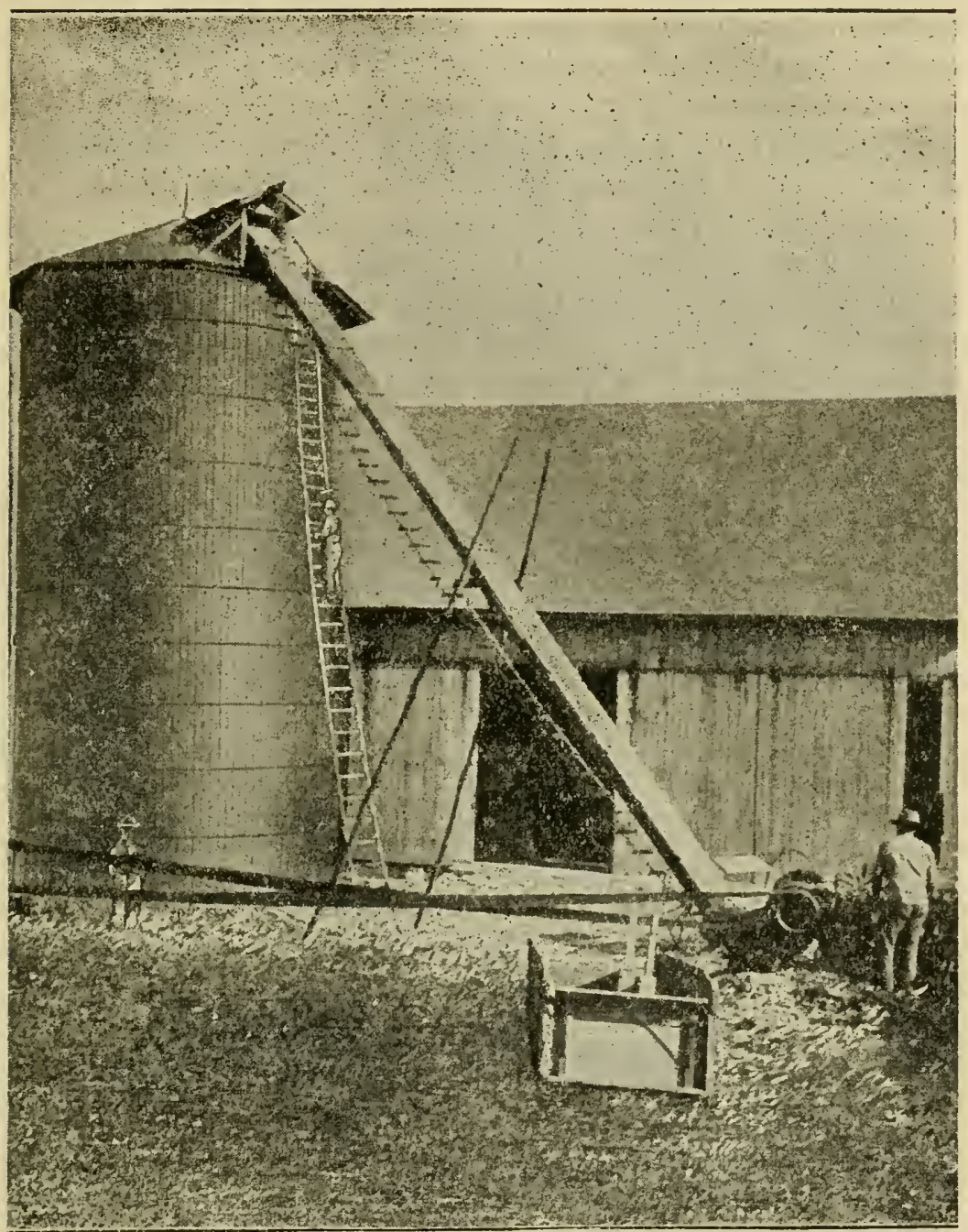

Fig. 28. Illustration showing a new stave silo in connection with an old barn on the Bossert Farm, east of Salem, Ohio. The "Ohio" Self-Feed Cutter and Metal Bucket Elevator are in operation, the engine not being shown in the photograph. 
is only limited by the amount that can be conveniently gotten to them. The largest sizes can be run by an ordinary threshing engine. These machines have been on the market for upwards of twenty-five years, and have been brought to a wonderful state of perfection. For durability, ease and reliability of operation, capacity and general utility, they are doubtless the most practical means of filling the silo.

The Nos. I6, I8, and I9 "Ohio" Cutters are the sizes mostly in use by farmers and dairymen, and the travelling feed table, which is long enough to receive a bundle of corn, is a most valuable feature, and has

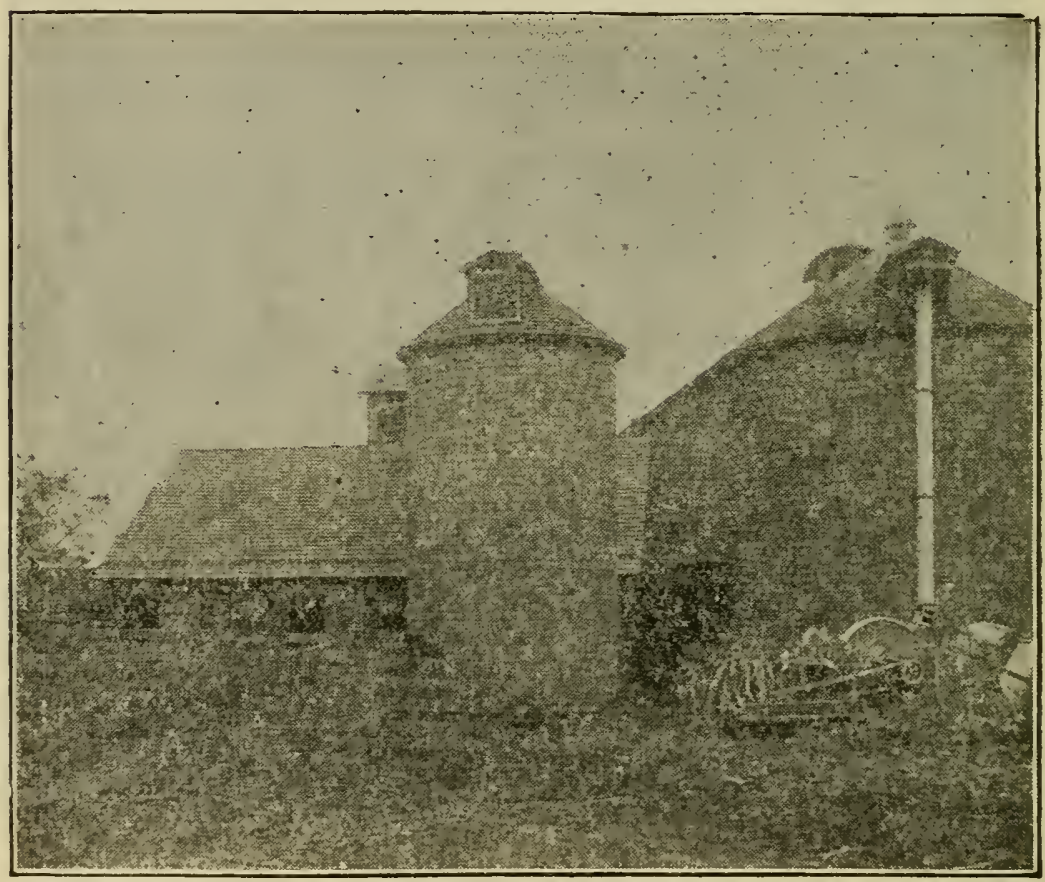

Fig. 29. Illustration showing "Ohio" No. I9 Blower in operation at the New Jersey State Experiment Station, New Brunswick, N.J., filling the silos there in the fall of 1902 . 
become almost universal on the "Ohio" machines used for silo filling. It decreases the labor of feeding and makes any size of machine about equal in capacity to the next size larger without it.

A new method of elevating the fodder in filling silos, has been introduced by the use of a blower-elevator, which blows the cut fodder into the silo through a continuous pipe. This device, therefore, takes the place of the carrier elevator described above. Blower elevators (see illustration of "Ohio" Cutter with Blower Elevator, Fig. 29) have been in use to a considerable extent for two or three years past, and in the opinion of a good many persons the Blower or Exhaust Eilevator is likely to come into general use in the future, and where sufficient power is available there is no difficulty in elevating the cut fodder into the highest silos.

Although the Blower Machines require somewhat more power than the older style carrier, there are numerous advantages over the metal bucket elevator, so that the "Ohio" Blowers are more in demand each year, and their popularity is now an assured fact; we mention below some of the features that have served to bring this style of the "Ohio" Cutters to the notice and favor of farmers and dairymen so rapidly.

The Blower Machine is quickly set up, taken down or moved, as all that is necessary is to remove the pipe, which is in sections of various lengths (from four to ten feet as desired), which requires but a few moments. This operation requires but little time as compared with that occupied in setting up or taking apart the chain elevator.

The Blower Machine is clean in operation, placing all of the corn in the silo and there is no litter around the machine when the filling is finished.

The action of the fan paddles is such that the corn is made much finer, and it therefore packs closer in the silo, thus enabling more fodder to be stored in the 
silo; the corn is all knocked off of the pieces of cobs and distributed through the cut fodder better, and the pieces of the heavy butts and joints are also split and knocked to pieces, all of which reduces the silage to a fine condition so that it is eaten up cleaner by the stock.

The fan or blower device is also likely to be more durable than the chain elevator.

Being somewhat of a new type of machine, the "Ohio" Blower is perhaps not as well known as the "Ohio" with Chain Elevator, thousands of which are in use the world over, to the entire satisfaction of their owners. The filling of silos by means of a wind blast, doing it as rapidly as the "Ohio" machines cut the fodder, is entirely feasible and a successful proposition, however, and there need be no fear on this point if the following points be kept in mind.

The machines must be run at the proper speed as reconmended by the manufacturers. A fan can only create a sufficient blast by running fast enough to force the air through the pipe at the rate of nine to ten thousand feet per minute. Green corn is heavy stuff, and requires a strong current of air to carry it through 30 or 40 feet of pipe at the rate of 10 to 20 tons per hour. It will be seen, therefore, that unless proper speed be maintained there will be no elevation of the material whatever. Thus, it will be seen that if the power at hand is not sufficient to maintain full speed when the cutters are fed to full capacity all that is necessary is to feed the machines accordingly, as is necessary with other kinds of machinery, such as threshing machines, grinding mills etc.

In setting a Blower Machine it is necessary to have the pipe as nearly perpendicular as possible, so that the current of air within the pipe will lift the material. This is especially true where the pipe is long, say 20 feet or more, because the green fodder being heavy will settle down on to the lower side of the pipe, if 
this has much slant, and the wind blast will pass over the fodder, thus allowing it to lodge, whereas if the pipe be perpendicular, or nearly so, no stoppage will occur. It is also necessary to see that full speed is attained before beginning to feed the machine, and also to stop the feeding while the machine is in full motion so that the Blower will have an opportunity to clear itself before shutting off the power.

There must be ample vent in the silo to prevent back pressure, as the tremendous volume of air forced into the silo with the cut fodder must have some means of escape.

If these few points be kept in mind there can be no possible doubt as to the successful operation of the blower elevator, and as previously stated, the increased demand for the "Ohio" machines is ample evidence on this point, and, as stated elsewhere in this volume, in the opinion of some of the most prominent dairymen and experiment station officials, blast elevators are likely to supersede the chain elevator within a few years.

(N. B. At the end of this volume will be found illustrations and descriptions of several sizes and styles of "Ohio" cutters, which the reader can refer to, in addition to the illustrations given here.)

Danger from Carbonic-Acid Poisoning in Silos.-As soon as the corn in the silo begins to heat, carbonicacid gas is evolved, and if the silo is shut up tight the gas will gradually accumulate directly above the fodder, since it is heavier than air and does not mix with it under the conditions given. If a man or an animal goes down into this atmosphere, there is great danger of asphyiation, as is the case under similar conditions in a deep cistern or well. Poisoning cases from this cause have occurred in filling silos where the filling has been interrupted for one or more days, and men have then gone into the silo to tramp down the cut corn. If the doors above the siloed mass are left open 
when the filling is stopped, and the silo thus ventilated, carbonic acid poisoning cannot take place, since the gas will then slowly diffuse into the air. Carbonic acid being without odor or color, to all appearances like ordinary air, it cannot be directly observed, but may be readily detected by means of a lighted lantern or candle. If the light goes out when lowered into the silo there is an accumulation of carbonic acid in it, and a person should open feed doors and fan the air in the silo before going down into it.

After the silage is made and the temperature in the silo has gone down considerably, there is no further evolution of carbonic acid, and therefore no danger in entering the silo even if this has been shut up tight. The maximnim evolution of carbonic acid, and consequently the danger of carbonic-acid poisoning comes during or directly after the filling of the silo.

\section{Covering the Siloed Fodder.}

Many devices for covering the siloed fodder have been recommended and tried, with varying success. The original method was to put boards on top of the fodder, and to weight them heavily by means of a foot layer of dirt or sand, or with stone. The weighting having later on been done away with, lighter material, as straw, hay, sawdust, etc., was substituted for the stone or sand. Building paper was often placed over the fodder, and boards on top of the paper. There is no special advantage derived from the use of buildingpaper, and it is now never used. Many farmers run some corn stalks, or green hnsked fodder, through the cutter after the fodder is all in. In the South, cottonseed hulls are easily obtained, and form a nost efficient and cheap cover.

None of these materials or any other recommended for the purpose can perfectly preserve the uppermost layer of silage, some four to six inches of the top layer being usually spoilt. Occasionally this spoilt silage 
may not be so bad but that cattle or hogs will eat it up nearly clean, but it is at best very poor food, and should not be used by any farmer who cares for the quality of his products. The wet or green materials are better for cover than dry substances, since they prevent evaporation of water from the top layer; when this is dry, air will be admitted to the fodder below, thus making it possible for putrefactive bacteria and molds to continue the destructive work begun by the fermentation bacteria, and causing more of the silage to spoil.

Use of Water in Filling Silos.-During late years the practice of applying water to the fodder in the silo has been followed in a large number of cases. The surface is tramped thoroughly and a considerable amount of water added. In applying the method at the Wisconsin Station, Prof. King, a few days after the completion of the filling of the silo, added water to the fodder corn at the rate of about ten pounds per square foot of surface, repeating the same process about ten days afterwards. By this method a sticky, almost impervious layer of rotten silage, a couple of inches thick, will form on the top, which will prevent evaporation of water from the corn below, and will preserve all but a few inches of the top. The method can be recommended in cases where the corn or clover goes into the silo in a rather dry condition, on account of drought or extreme hot weather, so as not to pack sufficiently by its own weight. While weighting of the siloed fodder has long since been done away with, it may still prove advantageous to resort to it where very dry fodder is siloed, or in case of shallow silos. Under ordinary conditions neither weighting nor applications of water should be necessary.

There is only one way in which all of the silage can be preserved intact, viz., by beginning to feed the silage within a few days after the silo has been filled. This method is now practiced by many farmers, espe- 
cially dairymen, who in this manner supplement scant fall pastures.

By beginning to feed at once from the silo, the siloing system is brought to perfection, provided the silo structure is air-tight, and constructed so as to admit of no unnecessary losses of nutrients. Under these conditions there is a very considerable saving of food materials over silage made in poorly-constructed silos, or over field-cured shocked fodder corn, as we have already seen.

\section{CLOVER SILAGE.}

Green clover may be siloed whole or cut, but the latter method is to be recommended. The clover should not be left to wilt between cutting and siloing, and the silo should be filled rapidly, so as to cause no unnecessary losses by fermentations.

The different species of clover will prove satisfactory silo crops ; ordinary red or medium clover is most used in Northwestern States, along with mammoth clover; the latter matures later than medium or red clover, and may therefore be siloed later than these. Alfalfa, or lucern, is, as previously stated, often siloed in the West. Under the conditions present there it will generally produce much larger yields than corn, and, preserved in a silo, will furnish a large supply of most valuable feed. Prof. Neale and others recommend the use of scarlet clover for summer silage, for Delaware and States under similar climatic conditions.

Says a Canadian dairy farmer: "If we were asked for our opinion as to what will most help the average dairy farmer, I think we should reply: Knowledge of a balanced ration, the Babcock test, and a summer silo; then varying the feed of individual animals according to capacity, as shown by scales and close observation."

\section{CLOVER FOR, SUMMER SILAGE.}

By filling clover into the silo at midsummer, or be- 
fore, space is utilized that would otherwise be empty; the silage will, furthermore, be available for feeding in the latter part of the summer and during the fall, when the pastures are apt to run short. This makes it possible to keep a larger number of stock on the farm than can be the case if pastures alone are to be relied upon, and thus greatly facilitates intensive farming. Now that stave silos of any size may be easily and cheaply put up, it will be found very convenient, at least on dairy farms, to keep a small separate silo for making clover silage that may be fed out during the summer, or at any time simultaneously with the feeding of the corn silage. This extra silo may also be used for the siloing of odd lots of forage that may happen to be available (see page 6o). It is a good plan in siloing clover or other comparatively light crops in rather small silos, to put a layer of corn on top that will weight down the mass below, and secure a more thorough packing and thereby also a better quality of silage.

In several instances where there has still been a supply of clover silage in the silo, green corn has been filled in on top of the clover, and the latter has been sealed and thus preserved for a number of years. Corn silage once settled and "sealed," will also keep perhaps indefinitely when left undisturbed in the silo, without deteriorating appreciably in feeding value or palatability.

Prof. Cottrell writing for Kansas farmers, says: "Silage will keep as long as the silo is not opened, and has been kept in good condition for seven years. This is a special advantage to Kansas dairymen, as in years of heavy crops the surplus can be stored in silos for years of drought, making all years good crop years for silo dairymen."

\section{FREEZING OF SILAGE.}

Freezing of silage has sometimes been a source of 
annoyance and loss to farmers in Northern States, and in the future, with the progress of the stave silo, we shall most likely hear more about frozen silage than we have in the past. As stated in the discussion of the stave silo, however, the freezing of silage must be considered an inconvenience rather than a positive detriment; when the silage is thawed out it is eaten with the same relish by stock as is silage that has never been frozen, and apparently with equally good results. If frozen silage is not fed out directly after thawed it will spoil and soon become unfit to be used for cattle food; thawed silage will spoil much sooner than ordinary silage that has not been frozen and thawed out. There is no evidence that silage which has been frozen and slowly thawed out, is less palatable or nutritious than silage of the same kind which had been kept free from frost.

The difficulty of the freezing of silage may be avoided by checking the rentilation in the silo and by leaving the door to the silo carefully closed in severe weather. If the top layer of silage freezes some of the warm silage may be mixed with the frozen silage an hour or two before feeding time, and all the silage will then be found in good condition when fed out. A layer of straw may be kept as a cover over the silage; this will prevent it from freezing, and is easily cleared off when silage is to be taken out. 


\section{CHAPTER V. \\ HOW TO FEED SILAGE.}

Silage is eaten with a relish by all kinds of farm animals, dairy and beef cattle, horses, mules, sheep, goats, swine, and even poultry. It should never be fed as sole roughage to any of these classes of stock, however, but always in connection with some dry roughage. The nearer maturity the corn is when cut for the silo, the more silage may safely be fed at a time, but it is always well to avoid feeding it excessively.

The silo should always be emptied from the top in horizontal layers, and the surface kept level, so as to expose as little of the silage as possible to the air. It should be fed out sufficiently rapidly to avoid spoiling of the silage; in ordinary Northern winter weather a layer a couple of inches deep should be fed off daily.

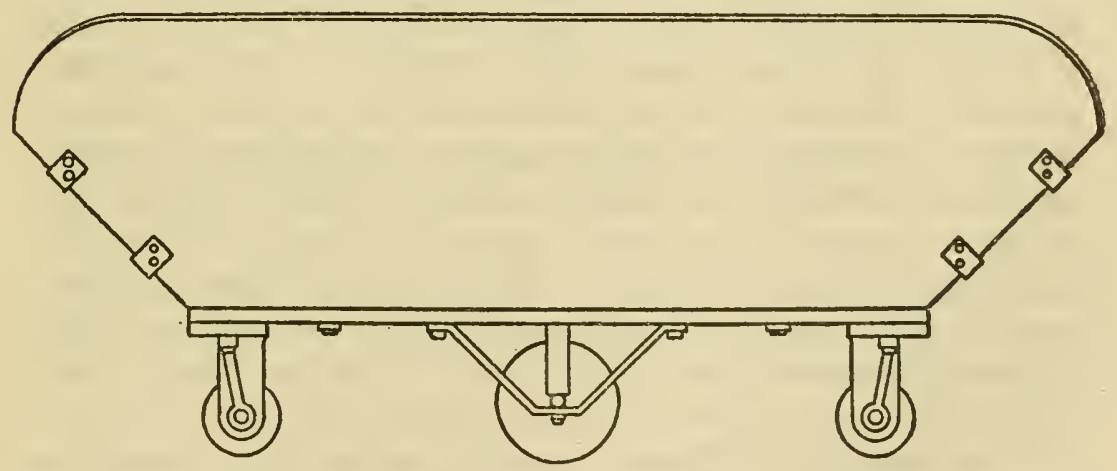

Fig. 30. Silage Truck.

SILAGE FOR MILCH COWS.

Silage is par excellence a cow feed, says Prof. Woll 
in his Book on Silage. Since the introduction of the silo in this country, the dairymen, more than any other class of farmers, have been among the most enthusiastic siloists, and up to the present time a larger number of silos are found in dairy districts than in any other regions where animal husbandry is a prominent industry. As with other farm animals, cows fed silage should receive other roughage in the shape of corn stalks, hay, etc. The quantities of silage fed should not exceed forty, or at the outside, fifty pounds per day per head. It is possible that a maximun allowance of only 25 or 30 pounds per head daily is to be preferred where the keeping quality of the milk is an important consideration, especially if the silage was made from somewhat immature corn. The silage may be given in one or two feeds daily, and, in case of cows in milk, always after milking, and not before or during same, as the peculiar silage odor may, in the latter case, in our experience reappear in the milk. (See below.)

Silage exerts a very beneficial influence on the secretion of milk. Where winter dairying is practiced, cows will usually drop considerably in milk towards spring, if fed on dry feed, causing a loss of milk through the whole remaining portion of the lactation period. If silage is fed there will be no such marked decrease in the flow of milk before turning out to grass, and the cows will be able to keep up well in milk until late in summer, or early in the fall, when they are dried up prior to calving. Silage has a similar effect on the milk secretion as green fodder or pasture, and if made from well-matured corn, is more like these feeds than any other feed the farmer can produce.

The feeding of silage to milch cows has sometimes been objected to when the milk was intended for the manufacture of certain kinds of cheese, or of condensed milk, and there are instances where such factories have enjoined their patrons from feeding silage to 
their cows. When the silage is properly prepared and properly fed, there can be no foundation whatever for this injunction; it has been repeatedly demonstrated that Swiss cheese of superior quality can be made from the milk of silage-fed cows, and condensing factories among whose patrons silage is fed have been able to manufacture a superior product. The qualily of the silage made during the first dozen years of silo experience in this country was very poor, being sour and often spoilt in large quantities, and, what may have been still more important, it was sometimes fed in an injudicious manner, cows being made to subsist on this feed as sole roughage. Under these conditions it is only natural that the quality of the milk should be impaired, and that manufacturers preferred to entirely prohibit the use of it rather than to teach their patrons to follow proper methods in the making and feeding of silage. There is an abundance of evidence at hand showing that good silage fed in moderate quantities will produce an excellent quality of both butter and cheese. According to the testimony of butter experts, silage not only does not injure the flavor of butter, but better-flavored butter is produced by judicious silage feeding than can be made from dry feed.

Silage in the production of "certified milk." -In answer to a question raised whether there is any objection made to the milk when the cows are fed silage, Mr. H. B. Gurler, the well-known Illinois dairyman, whose certified milk sent to the Paris Exposition in I900, kept sweet for one month without having any preservatives added to it, and was awarded a gold medal, gave the following information: "No, there is not. I have had persons who knew I was feeding silage imagine they could taste it. I caught one of the leading Chicago doctors a while ago. He imagined that he could taste silage in the milk, and I was not feeding it at all. When I first went into the business 
I did not feed any silage to the cows from which the certified milk was produced. I knew it was all right for butter making, as I had made butter from the milk of cows fed with silage, and sent it to New York in competition with butter made from dry food, and it proved to be the finer butter of the two. The first winter I had samples sent down to my family in De Kalb from the stable where we fed silage and from the stable where we were making the certified milk for Chicago, and in which we fed no silage. I presume I made one hundred comparative tests that winter of the milk from these two stables. My wife and daughter could not tell the difference between the two samples. In the large majority of cases they would select the milk from the cows fed silage as the sweeter milk."

It will serve as an illustration of the general use of silage among progressive dairymen in our country, to state that of one hundred farmers furnishing the feed rations fed to their dairy cows, in an investigation of this subject conducted by Prof. Woll in I894, sixtyfour were feeding silage to their stock, this feed being used a larger number of times than any other single cattle food, wheat bran only excepted.

The combinations in which corn silage will be used in feeding milch cows will depend a good deal on local conditions; it may be said in general that it should be supplemented by a fair proportion of nitrogenous feeds like clover hay, wheat bran, ground oats, linseed meal, gluten feed, cotton-seed meal, etc. As it may be of some help to our readers a number of balanced rations or such as are near enough balanced to produce good results at the pail, are presented below.

\section{Silage Rations for Milch Cozes.}

No. I. Corn silage, 35 lbs.; hay, 8 1bs.; wheat bran, 4 lbs.; ground oats, 3 lbs.; oil meal, 2 lbs. No. 2. Corn silage, 50 lbs.; corn stalks, ro lbs.; 
corn meal, 2 lbs.; wheat bran, 4 lbs.; malt sprouts, 3 lbs.; oil meal, I lb.

No. 3. Corn silage, 40 lbs.; clover and timothy mixed, ro lbs. ; wheat shorts, 3 lbs. ; gluten feed, 3 lbs. ; corn and cob meal, 3 lbs.

No. 4. Corn silage, 20 lbs. ; corn stalks, io lbs. : hay 4 lbs.; wheat bran, 4 lbs. ; gluten meal, 3 lbs.; ground oats, $3 \mathrm{lbs}$.

No. 5. Corn silage, 40 lbs. ; clover hay, io lbs.; oat feed, 4 lbs. ; corn meal, 3 lbs. ; gluten feed, 3 lbs.

No. 6. Corn silage, 45 lbs.; corn stalks, 5 lbs. ; oat straw, 5 lbs. ; dried brewers' grains, 4 lbs.; wheat shorts, 4 lbs.

No. 7. Corn silage, 35 lbs.; hay, io lbs.; corn meal, 3 lbs.; wheat bran, 4 lbs.; oats, 3 lbs.

No. 8. Corn silage, 40 lbs. ; corn stover, S 1bs.; wheat bran, 4 lbs.; gluten meal, 2 lbs. ; oil meal, 2 lbs.

No. 9. Corn silage, 20 lbs. ; clover and timothy hay, I 5 lbs.; corn meal, 3 lbs. ; ground oats, 3 lbs. ; oil meal, 2 lbs. ; cotton seed meal, I lb.

No. IO. Clover silage, 25 lbs.; corn stover, Io lbs.; hay, 5 lbs.; wheat shorts, 2 lbs. ; oat feed, 4 lbs.; corn meal, 2 lbs.

No. I I. Clover silage, 30 lbs. ; dry fodder corn, io lbs. ; oat straw, 4 lbs. ; wheat bran, 4 lbs.; malt sprouts, 2 lbs.; oil meal 2 lbs.

No. I 2. Clover silage, $40 \mathrm{lbs}$. ; hay, ro lbs. ; roots, 20 lbs. ; corn meal, 4 lbs.; ground oats, 4 lbs.

The preceding rations are only intended as approximate guides in feeding dairy cows. Every dairy farmer knows that there are hardly two cows that will act in exactly the same manner and will need exactly the same amount of feed. It is then important to adapt the quantities and kinds of feed given to the special needs of the different cows; one cow will fatten on corn meal, where another will be able to eat 
and make good use of two or three quarts of it. In the same way some cows will eat more roughage than others and do equally well on it as those that get more of the food in the form of more concentrated and highly digestible feeding stuffs. The only safe rule to go by is to feed according to the different needs of the cows ; to study each cow and find out how much food she can take care of without laying on flesh, and how she responds to the feeding of foods of different character, like wheat, bran, and corn meal, for instance. The specimen rations given in the preceding can, therefore, only be used to show the average amounts of common feeds which a good dairy cow can take in and give proper returns for.

The popularity of the silo with owners of dairy cattle has increased very greatly, says Prof. Plumb. Few owners of stock of this class, who have properlybuilt silos, and well-preserved silage, would discard silage as an adjunct to feeding. Silage certainly promotes milk flow. One great argument in favor of its use lies in the cheapness of production per ton, and the ability to store and secure a palatable, nutritious food in weather conditions that would seriously injure hay or dry fodder.

There is one important point that owners of milk cattle should bear in mind, and that is when the silo is first opened only a small feed should be given. In changing from grass or dry feed to silage, if a regular full ration is given, the silage will perhaps slightly affect the taste of the milk for a few milkings, and if the change is from dry feed it may cause too great activity of the bowels.

\section{SILAGE FOR BEEF CATTLE.}

Silage may be fed with advantage to beef cattle, in moderate quantities, up to about forty pounds a day. The health of the animals and the quality of the beef produced on moderate silage feeding, leave nothing to 
be wished for. If the silage is made from immature corn care must be taken not to feed too large quantities at the start, and to feed carefully, so as not to make the animals scour. Prof. Henry says in regard to the value of silage for fattening steers: "As with roots, silage makes the carcass watery and soft to the touch. Some have considered this a disadvantage, but is it not a desirable condition in the fattening steer? Corn and roughage produce a hard dry carcass, and corn burns out the digestive tract in the shortest possible time. With silage and roots, digestion certainly must be more nearly normal, and its profitable action longer continued. The tissues of the body are juicy, and the whole system must be in just that condition which permits rapid fattening. While believing in a large use of silage in the preliminary stages, and its continuance during most of the fattening period, I would recommend that gradually more dry food be substituted as the period advances, in order that the flesh may become more solid. Used in this way, I believe silage will become an important aid in steer feeding in many sections of the country. Results from Canada, Wisconsin, and Texas experiment stations show the broad adaptation of this food for stock feeding purposes."

Young stock may be fed half as much silage as full grown ones, with the same restrictions and precautions. as given for steers. Experience obtained at the Kansas. Station suggests that corn silage is not a fit food for breeding bulls, unless fed a few pounds only as a relish ; fed heavily on silage, bulls are said to lose virility and become slow and uncertain breeders.

\section{SILAGE FOR HORSES.}

When fed in small quantities, not to exceed fifteen pounds a day, silage is a good food for horses. It should be fed twice a day, a light feed being given at first and gradually increased as the animals become 
accustomed to the food. Some farmers feed it mixed with cut straw, two-thirds of straw, and one-third of silage, and feed all horses will eat of this mixed feed. Some horses object to silage at first on account of its peculiar odor, but by sprinkling some oats or bran on top of the silage and feeding only very small amounts to begin with, they soon learn to eat and relish it. Other horses take it willingly from the beginning. Horses not working may be fed larger quantities than work horses, but in neither case should the silage form more than a portion of the coarse feed fed to the horses. Silage-fed horses will look well and come out in the spring in better condition than when fed almost any other food.

Professor Cook says in regard to silage as a horse food: "It has been suggested by even men of high scientific attainments that silage is pre-eminently the food for cattle and not for other farm stock. This is certainly a mistake. If we raise fall colts, which I find very profitable, then silage is just what we need, and will enable us to produce colts as excellent as though dropped in the spring. This gives us our brood mares in first-class trim for the hard summer's work. I find silage just as good for young colts and other horses.'

An extensive Michigan farmer and horse breeder, gives his experience in regard to silage for horses as follows: "Last winter we had nearly two hundred horses, including Clydesdales, standard-bred trotters, and Shetland ponies. They were wintered entirely upon straw and corn silage, and this in face of the fact that I had read a long article in a prominent horse journal cautioning farmers from the use of silage, and citing instances where many animals had died, and brood mares had aborted from the liberal use of corn silage.

"Desiring to test the matter to the fullest extent, our stallions and brood mares, as well as all the young stock, were fed two full rations of silage daily, and 
one liberal ration of wheat or oat straw. The result with our brood mares was most phenomenal, for we now have to represent every mare that was then in foal on the farm, a weanling, strong and vigorous, and apparently right in every way, with only one exception, where the colt was lost by accident. Of course there may have been something in the season more favorable than usual, but this was the first year in my experience when every colt dropped on the farm was saved."

The following experience as to the value of silage as a food for horse and other farm animals comes from the Ohio Station: "Our silo was planned and filled with special reference to our dairy stock, but after opening the silo we decided to try feeding the silage to our horses, calves, and hogs. The result was eminently satisfactory. We did not find a cow, calf, horse, colt, or hog that refused to eat, or that did not eat it with apparent relish, not only for a few days, but for full two months. The horses were given one feed of twenty pounds each per day in place of the usual amount of hay, for the period above named, and it was certainly a benefit. Their appetites were sliarpened, and the healthfulness of the food was further manifest in the new coat of hair which came with the usual spring shedding. The coat was glossy, the skin loose. and the general appearance was that of horses running upon pasture.'

Doctor Bailey states that silage has as good an effect on work and driving horses as an occasional feed of carrots or other roots, and Rew informs us that there is a demand for silage in London and other English cities, especially for omnibus, cab, and tram horses. According to the testimony of Mr. H. J. Elwes, the cart horses fed silage "looked in better condition and brighter in their coats than usual at this time of the year.'

From experiments conducted at Virginia Station, Prof. Nourse concluded that "it would appear that 
silage would make a good roughage for horses, when used in connection with hay or stover or grain, but that these animals should become accustomed to the food by degrees, and that this is as important as when changing from old to new corn, or from hay to grass."

What has been said about silage as a food for horses will most likely apply equally well to mules, although only very limited experience has so far been gained with silage for this class of farm animals.

\section{Silage for Sheep.}

Silage is looked upon with great favor among sheep men, says Prof. Woll in his book on Silage; sheep do well on it, and silage-fed ewes drop their lambs in the spring without trouble, the lambs being strong and vigorous. Silage containing a good deal of corn is not well adapted for breeding stock, as it is too fattening; for fattening stock, on the other hand, much corn in the silage is an advantage. Sheep may be fed a couple of pounds of silage a day and not to exceed five or six pounds per head. Professor Cook reports as follows in regard to the value of silage for sheep: "I have fed ensilage liberally to sheep for three winters and an remarkably pleased with the results. I make ensilage half the daily ration, the other half being corn stalks, or timothy hay, with bran or oats. The sheep do exceedingly well. Formerly I was much troubled to raise lambs from grade Merino ewes. Of late this trouble has almost ceased. Last spring I hardly lost a lamb. While ensilage may not be the entire cause of the change, I believe it is the main cause. It is positively proved that ensilage is a most valuable food material, when properly fed, for all our domestic animals."

Mr. J. S. Woodward, a well-known New York farmer and Farmers' Institue worker, who has made a specialty of early-lamb raising, says, in an address 
before the New York Agricultural Society, regarding silage as feed for lambs: "In order to be successful in raising fine lambs it is imperative that the ewes and lambs both should have plenty of succulent food. Nothing can supply the deficiency. For this purpose roots of almost any kind are good. Turnips, rutabagas, mangolds are all good. Corn silage is excellent. Could I have my choice I would prefer both silage and roots. If $I$ were depending on silage alone for succulent food I would give four pounds per hundred pounds live weight of sheep, all at one feed, at the forenoon feed; but when feeding both silage and roots I would feed silage in the morning and roots in the afternoon."

Mr. J. M. Turner of Michigan says concerning silage for sheep: "Of late years we have annually put up 3,200 tons of corn ensilage, and this has been the principal ration of all the live stock at Springdale Farm, our Shropshire sheep having been maintained on a ration of ensilage night and morning, coupled with a small ration of clover hay in the middle of the day. This we found to fully meet the requirements of our flock until after lambing, from which time forward we of course added liberal rations of wheat bran, oats, and old-process linseed meal to the ewes, with a view of increasing their flow of milk and bringing forward the lambs in the most vigorous possible condition. Our flock-master was somewhat anxious until after the lambs dropped, but now that he saved 196 lambs from 122 ewes, his face is wreathed in smiles, and he gives the ensilage system the strongest endorsement." Mr. Turner states that, after becoming accustomed to the silage, his horses, cattle, and sheep would all push their noses down through the hay, if there was silage at the bottom of the manger, and little or no hay would be eaten until the silage was first taken.

The following interesting experience illustrating 
the value of silage for sheep feeding is given by Mr. William Woods, a celebrated English breeder of Hampshire-Downs: "Last year, in August, I found myself with a flock of some I,200 Hampshire-Down ewes, and about twelve or fourteen acres of swedes, on a farm of 4,000 acres, and these were all the roots there were to feed them and their lambs during the winter. Knowing how we should suffer from want of milk after lambing in January and February, I thought I would try (which no doubt has often been tried elsewhere, though not in this district) the effect of ensilage on ewes after lambing, having learned by hearsay that it increased the milk of cows nearly 30 per cent. I at once set to work to irrigate what water meadows I could spare, and in the month of October had a crop of grass that, had it been possible to make it into hay, would have made a ton of hay to the acre. I bought from the Aylesbury Dairy Company one of their Johnson's ensilage rick presses, and put some seventy to eighty tons of cut meadow grass under pressure. It must, however, be borne in mind that second cut water meadow grass is some of the poorest stuff that is consumed, either green or in hay, and, therefore, my ensilage was not as good, and consequently not as favorable a trial, as if it had been made of better material.

"In January, when well into lambing, I opened the stack, and began to feed it to the ewes that had lambed. At first they hardly cared to eat it, but by degrees they seemed to like it more. They had a night and morning meal of best sainfoin hay, and a small lot of ensilage with the cake given at midday. After three weeks' trial, what the shepherd observed was this: That when best sainfoin hay worth $\mathcal{E}_{4}$ a ton, was put in the cages, and ensilage in the troughs at the same time, half the sheep would go to the hay and half to the ensilage, although there was sufficient accommodation for the whole flock at either sort, and 
we now observe that with the ewes that are most constant to the ensilage, their lambs are nourished better than the others. We have not lost a single lamb from scours, and have some 470 lambs from 380 ewes lambed as yet, which I think proves the value of the experiment. As soon as the stuff arrives in carts the ewes are crazy for it, and almost come over the hurdles, so eager are they to get at this new sort of feed, which, as I have stated, is only water meadow grass ensilaged.'"

\section{Silage for Swine.}

The testimony concerning the value of silage as a food for swine is conflicting, both favorable and unfavorable reports being at hand. Many farmers have tried feeding it to their hogs, but without success. On the other hand, a number of hog-raisers have had good success with silage, and feed it regularly to their swine. It is possible that the differences in the quality of the silage and of the methods of feeding practiced explain the diversity of opinions formed concerning silage as hog food. According to Professor Cook, Col. F. D. Curtiss, the great American authority on the swine industry, states that silage is valuable to add to the winter rations of our swine. Mr. J. W. Pierce of Indiana writes in regard to silage for hogs: "We have fed our sows, about twenty-five in number, for four winters, equal parts of ensilage and corn meal put into a cooker, and brought up to a steaming state. It has proved to be very beneficial to them. It keeps up the flow of milk of the sows that are nursing the young, equal to when they are running on clover. We find, too, when the pigs are farrowed, they become more robust, and take to nursing much sooner and better than they did in winters when fed on an exclusively dry diet. We also feed it to our sheep. To sixty head we put out about six bushels of ensilage." Dr. Bailey, the author 
of "'The Book on Ensilage," fed large hogs ten pounds of silage, and one pound of wheat bran, with good results; the cost of the ration did not exceed 2 cents per day. He states that clover silage would be excellent, and would require no additional grain. Young pigs are exceedingly fond of the silage. Feeding experiments conducted at Virginia Experiment Station show that silage is an economical maintenance feed for hogs, when fed in connection with corn, but not when fed alone.

In feeding silage to hogs, care should be taken to feed only very little, a pound or so, at the start, mixing it with corn meal, shorts, or other concentrated feeds. The diet of the hog should be largely made up of easily digested grain food; bulky, coarse feeds like silage can only be fed to advantage in small quantities, not to exceed three or four pounds per head, per day. As in case of breeding ewes, silage will give good results when fed with care to brood sows, keeping the system in order, and producing a good flow of milk.

\section{Silage for Poultry.}

But little experience is at hand as to the use of silage as a poultry food; some farmers however, are feeding a little silage to their poultry with good success. Only small quantities should of course be fed, and it is beneficial as a stimulant and a regulator, as much as a food. A poultry raiser writes as follows in Orange Judd Farmer, concerning his experience in making and feeding silage to fowls. Devices similar to that here described have repeatedly been explained in the agricultural press. "Clover and corn silage is one of the best winter foods for poulty raisers. Let me tell you how to build four silos for $\$ \mathrm{I}$. Buy four coal-oil barrels at the drug store, burn them out on the inside, and take the heads out. Go to the clover field when the second crop of the small June clover is 
in the bloom, and cut one-half ton three-eights of an inch in length, also one-half ton of sweet corn, and run this through the feed cutter. Put into the barrel a layer of clover, then a layer of corn. Having done this, take a common building jack-screw and press the silage down as firmly as possible. Then put on this a very light sprinkling of pulverized charcoal, and keep on putting in clover and corn until you get the barrel as full as will admit of the cover being put back. After your four barrel silos are filled, roll them out beside the barn, and cover them with horse manure, allowing them to remain there thirty days. Then put them away, covering with cut straw or hay. When the cold, chilling winds of December come, open one of these 'poultrymen's silos,' take about twenty pounds for one hundred hens, add equal parts of potatoes, ground oats, and winter rye, place same in a kettle and bring to a boiling state. Feed warm in the morning, and the result will be that you will be enabled to market seven or eight dozen eggs per day from one hundred hens through the winter, when eggs bring good returns."

ADDITIONAL TESTIMONY AS TO THE VALUE OF SILAGE.

Corn Silage compared with root crops.-Root crops are not grown to any large extent in this country, but occasionally an old-country farmer is met with who grows roots for his stock, because his father did so, and his grandfather and great-grandfather before him. This is what a well-known English writer, R. Henry Rew, says as to the comparative value of roots and silage, from the standpoint of an English farmer :

"The root crop has, for about a century and a half, formed the keystone of arable farming; yet it is the root crop whose position is most boldly challenged by silage. No doubt roots are expensive-say $£$ Io per acre as the cost of producing an ordinary crop of turnips-and precarious, as the experience of the winter 
of 1887-8 has once more notably exemplified in many parts of the country. In a suggestive article in the Farming World Almanac for I $888 \mathrm{Mr}$. Primrose McConnell discusses the question: 'Are Turnips a Necessary Crop?' and sums up his answer in the following definite conclusion :

" Everything, in short, is against the use of roots, either as a cheap and desirable food for any kind of live stock, as a crop suited for the fallow break, which cleans the land at little outlay, or as one which preserves or increases the fertility of the soil.'

"If the growth of turnips is abandoned or restricted ensilage comes in usually to assist the farmer in supplying their place. . . When one comes to compare the cultivation of silage crops with that of roots, there are two essential points in favor of the former. One is their smaller expense, and the other is their practical certainty. The farmer who makes silage can make certain of his winter store of food, whereas he who has only his root crop may find himself left in the lurch at a time when there is little chance of making other provision."

We have accurate information as to the yields and cost of production of roots and corn silage in this country from a number of American Experiment Stations. This shows that the tonnage of green or succulent feed per acre is not materially different in case of the two crops, generally speaking. But when the quantities of dry matter harvested in the crop are considered, the corn has been found to yield about twice as much as the ordinary root crops. According to data published by the Pennsylvania Station, the cost of an acre of beets in the pit amounts to about $\$ 56$, and of an acre of corn in the silo about $\$ 2 \mathrm{I}$, only half the quantities of food materials obtained, and at more than double cost.

When the feeding of these two crops has been determined, as has been the case in numerous trials at 
experiment stations, it has been found that the dry matter of beets certainly has no higher, and in many cases has been found to have a lower value than that of corn silage; the general conclusion to be drawn, therefore, is that "beets cost more to grow, harvest and store, yield less per acre, and produce at best no more and no better milk or other farm products than corn silage.'

Corn silage compared with hay. A ton and a half of hay per acre is generally considered a good average crop in humid regious. Since hay contains sbout 86 per cent. dry matter, a crop of $\mathrm{I} / 2$ tons means 2,580 pounds of dry matter. Against this yield we have yields of 5,000 to 9,000 pounds of dry matter, or twice to three and a half times as much, in case of fodder corn. An average crop of green fodder will weigh twelve tons, of Northern varieties, and eighteen tons, of Southern varieties. Eistimating the percentage of dry matter in the former at 30 per cent, and in the latter at 20 per cent, we shall have in either case a yield of 7,200 pounds of dry matter. If we allow for ro per cent. of loss of dry matter in the silo there is still 6,500 pounds of dry matter to be credited to the corn. The expense of growing the corn crop is, of course, higher than that of growing hay, but by no means sufflciently so to offset the larger yields. It is a fact generally conceded by all who have given the subject any study, that the hay crop is the most expensive crop used for the feeding of our farm animals.

The late Sir John B. Lawes, of Rothamsted Experiment Station (England) said, respecting the relative value of hay and (grass) silage: "It is probable that when both (i. e., hay and silage) are of the very best quality that can be made, if part of the grass is cut and placed in a silo, and another part is secured in the stack without rain, one might prove as good food as the other. But it must be borne in mind that while the production of good hay is a matter of 
uncertainty - from the elements of success being beyoud the control of the farmer-good silage, by taking proper precautions, can be made with a certainty."

A few feeding experiments with corn silage vs. hay will be mentioned in the following.

In an experiment with milch cows conducted at the New Hampshire Station, the silage ration, containing 16.45 pounds of digestible matter, produced 21.0 pounds of milk, and the hay ration, containing 16.83 pounds digestible matter, produced I8.4 pounds milk; calculating the quantities of milk produced by roo pounds of digestible matter in either case, we find on the silage ration 127.7 pounds of milk, on the hay ration, IO9.3 pounds, or $I 7$ per cent. in favor of the silage ration.

In a feeding experiment with milch cows at the Maine Station, in which silage likewise was compared with hay, the addition of silage to the ration resulted in a somewhat increased production of milk solids, which was not caused by an increase in the digestible food materials eaten, but which must have been due either to the superior value of the nutriments of the silage over those of the hay or to the general physiological effect of feeding a greater variety of foods. 8.8 pounds of silage proved to be somewhat superior to $1.9^{8}$ pounds of hay (mostly timothy), the quantity of digestible material being the same in the two cases.

In another experiment, conducted at the same station, where silage was compared with hay for steers, a pound of digestible matter from the corn silage produced somewhat more growth than a pound of digestible matter from timothy hay. The difference was small, however, amounting in the case of the last two periods, where the more accurate comparison is possible, to an increased growth of only i 5 pounds of live weight for each ton of silage fed.

Corn Silage compared with fodder corn. The cost of 
production is the same for the green fodder up to the time of siloing, in case of both systems; as against the expense of siloing the crop comes that of shocking, and later on, placing the fodder uncler shelter in the field-curing process; further husking, cribbing, and grinding the corn, and cutting the corn stalks, since this is the most economical way of handling the crop, and the only way in which it can be fully utilized so as to be of as great value as possible for dry fodder. Professor King, found the cost of placing corn in the silo to be 58.6 cents per ton, on the average for five Wisconsin farms, or, adding to this amount, interest and taxes on silo investment, and insurance and maintenance of silo per ton, 73.2 cents. The expense of shocking and sheltering the cured fodder and, later cutting the same, will greatly exceed that of siloing the crop; to obtain the full value in feeding the ear corn, it must, furthermore, in most cases, be ground, costing Io cents or more a bushel of $70 \mathrm{lbs}$. The advantage is, therefore, decidedly with the siloed fodder in economy of handling, as well as in the cost of production.

-The comparative feeding value of corn silage and fodder corn has been determined in a large number of trials at different experiment stations. The earlier ones of these experiments were made with only a couple of animals each, and no reliance can, therefore, be placed on the results obtained in any single experiment. In the later experiments a larger number of cows have been included, and these have been continued for sufficiently long time to show what the animals could do on each feed.

A few experiments illustrating the value of silage as a stock food may be quoted. Prof. Henry fed two lots of steers on a silage experiment. One lot of four steers was fed corn silage exclusively, and another similar lot corn silage with shelled corn. The former lot gained 222 pounds in thirty-six days, and the latter 
lot 535 pounds, or a gain of 1.5 pounds per day per head for the silage-fed steers, and 3.7 pounds per day for the silage and shelled-corn fed steers. Prof. Emery fed corn silage and cotton-seed meal, in the proportion of eight to one, to two three-year-old steers, at the North Carolina Experiment Station. The gain made during thirty-two days was, for one steer 78 pounds, and for the other 85.5 pounds, or 2.56 pounds per head per day.

The late well-known Wisconsin dairyman, Hon. Hiram Smith, in I 888 gave the following testimony concerning the value of silage for milch corvs: "My silo was opened December Ist, and thirty pounds of ensilage was fed to each of the ninety corvs for the night's feed, or 2,700 pounds per day, until March Io, one hundred days, or a total of I 35 tons, leaving sufficient ensilage to last until May Ioth. The thirty pounds took and well filled the place of ten pounds of good hay. Had hay been fed for the night's feed in place of the ensilage, it would have required 900 pounds per day for the ninety cows, or a total for the one hundred days of forty-five tons.

"It would have required, in the year I887, fortyfive acres of meadow to have produced the hay, which, if bought or sold, would have amounted to $\$$ I 4.00 per acre. The 135 tons of ensilage were produced on $8 \mathrm{~T} / 2$ acres of land, and had a feeding value, as compared with hay, of \$74. I I per acre." As the conclusion of the whole matter, Mr. Smith stated that "three cows can be wintered seven months on one acre producing I 6 tons of ensilage, while it required two acres of meadow in the same year of $\mathrm{r} 887$, to winter one cow, with the same amount of ground feed in both cases.'

Professor Shelton, formerly of Kansas Agricultural College, gives a powerful plea for silage in the following simple statement: "The single fact that the product of about two acres of ground kept our herd of fifty head of cattle five weeks with no other feed of the 
fodder kind, except a small ration of corn fodder given at noon, speaks whole cyclopedias for the possibilities of Kansas fields when the silo is called in as an adjunct.'”

In conclusion. We will bring our discussions of the silo and its importance in American agriculture, to a close by quoting the opinicns of a few recognized leaders on agricultural matters as the value of silo and silage :

Says Ex-Gov. Hoard, the editor of Hoard's Dairyman, and a noted dairy lecturer: "For dairying all the year around the silo is almost indispensable."

Prof. Hills, the director of Vermont Experiment Station: "It was long ago clearly shown that the most economical farmi-grown carbohydrates raised in New England are derived from the corn plant, and that they are more economically preserved for cattle feeding in the silo than in any other way."

H. C. Wallace, editor Creamery Gazette : "While not an absolute necessity, the silo is a great convenience in the winter, and in times of protracted dryness almost a necessity in summer.'

Prof. Carlyle, of Wisconsin Agricultural College: "A silo is a great labor-saving device for preserving the cheapest green fodder in the best form.

C. P. Goodrich, conductor of Farners' Institutes in Wisconsin, and a well-known lecturer and authority on dairy topics: "A farmer can keep cows profitably without a silo, but he can make more profit with one, because he can keep his cows with less expense and they will produce more.'

Prof. Dean, of Ontario Agricultural College: "The silo is becoming a greater necessity every year in Ontario."

Thus it will be seen that from all parts of the world wherever the silo is in use, the evidence points in favor of silage, there no longer being an argument against 
it, in connection with the dairy, and especially in latitudes where corn can be grown.

Economy in production of feed materials means increased profits. Competition establishes the price at which the farmer and dairyman must market his products, but by the study of approved and modern methods the farmer can regulate his profits. 


\section{CHAPTER VI.}

\section{A FEEDERS' GUIDE.}

It has been thought best, in order to increase the usefulness of this little book to practical farmers, to add to the specific information given in the preceding as to the making and feeding of silage, a brief general outline of the main principles that should govern the feeding of farm animals. This will include a statement of the character of the various components of the feeding stuffs used for the nutrition of farm stock, with tables of composition, and a glossary of scientific agricultural terms often met with in agricultural papers, experiment station reports, and similar publications. Many of these terms are used constantly in discussion of agricultural topics, and unless the farmer has a fairly clear idea of their meaning the discussions will often be of no value to him. The information given in the following is put in as plain and simple language as possible, and only such facts are given as are considered of fundamental importance to the feeder of farm stock.

\section{COMPOSITION OF THE ANIMAL BODY.}

The most important components of the animal body are: water, ash, protein, and fat. We shall briefly describe these components.

Water is found in larger quantities in the animal body than any other substance. It makes up for about a third to nearly two-thirds of the live weight of farm animals. The fatter the animal is the less water is found in its body. We may consider 50 per cent of the body weight a general average for the water content of the body of farm animals. When it comes to 
animal products used for food purposes, there are wide variations in the water content; from between 80 and 90 per cent in case of milk, to between 40 and 60 per cent in meat of various kinds, abont $\mathrm{I} 2$ per cent in butter, and less than io per cent in fat salt pork.

Ash or mineral matter is that portion of the animal body which remains behind when the body is burned. The bones of animals contain large quantities of mlneral matter while the muscles and other parts of the body contain only small amounts; it mnst not be concluded, however, that the ash materials are of minor importance for this reason; both the young and full grown animal require a constant supply of ash materials in their food; if the food should not contain a certain minimum amount of ash materials, and of various compounds contained therein which are essential to life, the animal will turn sick very soon, and if the deficiency is not made up will die, no matter how much of other food components is supplied. As both ash and water are either present in sufficient quantities in feeding stuffs, or can be easily supplied, the feeder does not ordinarily need to give much thought to these components in the selection of foods for his stock.

Protein is not the name of any single substance, but for a large group of very complex substances that have certain characteristics in common, the more important of which is that they all contain the element nitrogen. Hence these substances are also known as nitrogenous components. The most important protein substances found in the animal body are: lean meat, fibrin, all kinds of tendons, ligaments, nerves, skin, brain, in fact the entire working machinery of the animal body. The casein of milk and the white of the egg are, furthermore, protein substances. It is evident from the enumeration made that protein is to the animal body what the word implies, the most important, the first.

Fat is a familiar component of the animal body ; it is distributed throughout the body in ordinary cases, 
but is found deposited on certain organs, or under the skin, in thick layers, in the case of very fat animals.

The animal cannot, as is well known, live on air ; it must manufacture its body substances and products from the food it eats, hence the next subject for consideration should be :

\section{Composition of Feeding Stuffs.}

The feeding stuffs used for the nutrition of our farm aninals are composed of sinilar compounds as those which are found in the body of the animal itself, although the components in the two cases are rarely identical, but can be distinguished from each other in most cases by certain chemical reactions. The animal body through its rital functions has the faculty of changing the various food substances which it finds in the food in such a way that they are in many instances different from any substances found in the vegetable world.

The components of feeding stuffs which are generally enumerated and taken into account in ordinary chenical fodder analysis, or in discussions of feeding problems are: Water (or Moisture, as it is of ten called), ash materials, fat (or ether-extract), protein, crude fiber, and nitrogen-free extract; the two components last given are sometimes grouped together under the name Carbhydrates. These components are in nearly all cases mixtures of substances that possess certain properties in common; and as the mixtures are often made up of different components, or of the same conlponents in varying proportions, it follows that even if a substance is given in a table of composition of feeding stuffs, in the same quantities in case of two different feeds, these feeds do not necessarily have the sane food value as far as this component alone is concerned.

Water or moisture is found in all feeding stuffs, whether succulent or apparently dry. Green fodders contain from 60 to 90 per cent of water, according to 
the stage of maturity of the fodder; root crops contain between 80 and 90 per cent, while hay of different kinds, straw, and concentrated feeds ordinarily have water contents ranging between $\mathrm{I} 5$ and 8 per cent.

Ash or mineral matter is found in all plant tissues and feeding stuffs. We find most ash in leafy plants, or in refuse feeds made up from the outer covering of grains or other seeds, viz., from 4 to 8 per cent; less in the cereals and green fodder, and least of all in roots. A fair amount of ash materials is a necessity in feeding young stock and pregnant animals, and on!y limited amounts of foods low in ash should be fed to such animals; refuse feed from starch and glucose factories which have been treated with large quantities of water should, therefore, be fed with care in such cases.

Fat or ether extract is the portion of the feeding stuff which is dissolved by ether or benzine. It is found in large quantities in the oil-bearing seeds, more than one-third of these being composed of oil or fat; the oil-mill refuse feeds are also rich in fat, especially cotton seed meal and old-process liniseed meal; other feeds rich in fat are gluten meal and feed, grano-gluten and rice meal. The ether extract of the coarse fodders contains considerable wax, resins, and other substances which have a low feeding value, while that of the seeds and by-products from these are essentially pure fat or oil.

Protein or flesh forming substances are considered of the highest importance in feeding animals, because they supply the material required for building up the tissues of the body, and for maintaining these under the wear caused by the vital functions. Ordinarily the feed rations of most farmers are deficient in protein since most of the farm-grown foods (not including clover, alfalfa, peas and similar crops) contain only small amounts of these substances. The feeding stuffs richest in protein are, among the coarse foods: those already mentioned; among the concentrated foods: 
cotton-seed meal, linseed meal, gluten meal, gluten feed, grano-gluten, buckwheat middlings, and the flour-mill, brewery, and distillery refuse feeds. The protein substances are also called nitrogenous bodies, for the reason given above, and the other organic (combustible) components in the feeding stuffs are spoken of as non-nitrogenous substances. The non nitrogenous components of feeding.stuffs, therefore, include fat and the two following groups, crude fiber and nitrogen-free extract.

Crude fiber is the framework of the plants, forming the walls of the cells. It is usually the least digestible portion of plants and vegetable foods, and the larger proportion present thereof the less valuable the food is. We find, accordingly, that the fodders containing most crude fiber are the cheapest foods and least prized among feeders, as, e. g., straw of the various cereal and seed-producing crops, corncobs, oat and rice hulls, cotton-seed hulls, buckwheat hulls, and the like. These feeding stuffs, in so far as they can be considered as such, contain as a rule between 35 and 50 per cent of crude fiber. Concentrated feeding stuffs, on the other hand, often contain less than 5 per cent of crude fiber, and in the cereals only a couple of per cent of crude fiber are found.

Nitrogen-free extract is a general name for all that is left of the organic matter of plants and fodders after deducting the preceding groups of compounds. It includes some of the most valuable constituents of feeding stuffs, which make up the largest bulk of the food materials ; first in importance among these constituents are starch and sugar, and, in addition, a number of less well-known substances of similar compositions, like pentosans, gums, organic acids, etc. Together with crude fiber the nitrogen-free extract forms the group of substances known as carbohydrates. A general name for carbohydrates is heat-producing substances, since this is one important function which 
they fill; they are not as valuable for this purpose, pound for pound, as fat, which also is often used for the purpose by the animal organism, but on account of the large quantities in which the carbohydrates are found in most feeding stuffs they form a group of food materials second to none in importance. Since it has been found that fat will produce about $2 \mathrm{~T} / 4$ times as much heat as carbohydrates on combustion, the two components are often considered together in tables of composition of feeding stuffs and in discussions of the feeding value of different foods, the per cent of fat being multiplied by $2 \frac{1}{4}$ in such cases, and added to the per cent of carbohydrates (i. e., crude fiber plus nitrogen-free extract) in the foods. As this renders comparisons much easier, and simplifies discussions for the beginner, we shall adopt this plan in the tables and discussions given in this Guide.

Carbohydrates and fat not only supply heat on being oxidized or burned in the body, but also furnish materials for energy used in muscular action, whether this be voluntary or involuntary. They also in all probability are largely used for the purpose of storing fatty tissue in the body of fattening animals, or of other animals that are fed an excess of nutrients above what is required for the production of the necessary body heat and muscular force.

To summarize briefly the uses of the various food elements: Protein is required for building up muscular tissue, and to supply the breaking down and waste of nitrogenous components constantly taking place in the living body. If fed in excess of this requirement it is used for production of heat and energy. The non-nitrogenous organic components, i. e., carbohydrates and fat, furnish material for supply of heat and muscular exertion, as well as for the production of fat in the body or in the milk, in case of milch cows giving milk.

Digestibility of foods. Only a certain portion of a 
feeding stuff is of actual value to the animal, viz., the portion which the digestive juices of the animal can render soluble, and thus bring into a condition in which the system can make the uses of it called for ; this digestible portion ranges from half or less to more than 96 per cent in case of highly digestible foods. The rest is simply ballast, and the more ballast, i. e., the less of digestible matter a food contains, the more the value of the digestible portion is reduced. Straw, e. g., is found, by means of digestion experiments, to contain between 30 and 40 per cent of digestible matter in all, but it is very doubtful whether an animal can be kept alive for any length of time when fed straw alone. It very likely costs him more effort to extract the digestible matter therefrom than the energy this can supply. An animal lives on and produces not from what he eats but from what he digests.

Relative value of feeding stuffs. Since the price of different feeding stuffs varies greatly with the locality and season, it is impossible to give definite statements as to the relative economy which will hold good always. It may be said, in general, that the feeding stuffs richest in protein are our most costly and at the same time our most valuable foods. Experience has shown to a certainty that a liberal supply of protein is an advantage in feeding most classes of farm animals, so that if such feeding stuffs can be obtained at fair prices, it will pay to feed them quite extensively, and they must enter into all food rations in fair quantities in order that the animals may produce as much milk, meat, or other farm products, as is necessary to render them profitable to their owner. The following statement shows a classification of feeding stuffs which may prove helpful in deciding upon kinds and amounts of feeds to be purchased or fed. 
Classification of Cattle Foods.

\begin{tabular}{|c|c|c|c|c|c|}
\hline \multicolumn{6}{|c|}{ COARSE FEEDS. } \\
\hline \multicolumn{2}{|l|}{1} & \multicolumn{2}{|c|}{2} & \multicolumn{2}{|r|}{3} \\
\hline \multicolumn{2}{|c|}{$\begin{array}{l}\text { Low in protein. } \\
\text { High in carbohy- } \\
\text { drates. } \\
50 \text { to } 65 \text { per cent } \\
\text { digestible. }\end{array}$} & \multicolumn{2}{|c|}{$\begin{array}{l}\text { Medium in pro- } \\
\text { tein. } \\
\text { Medium in carbo- } \\
\text { hydrates. } \\
55 \text { to } 65 \text { per cent } \\
\text { digestible. }\end{array}$} & \multicolumn{2}{|c|}{$\begin{array}{l}\text { Low in protein. } \\
\text { High in carbo- } \\
\text { hydrates, } \\
85 \text { to } 95 \text { per cent } \\
\text { digestible. }\end{array}$} \\
\hline $\begin{array}{l}\text { Hays, straws, } \\
\text { corn fodder, } \\
\text { corn stover, } \\
\text { silage, cerea } \\
\text { fodders. }\end{array}$ & & $\begin{array}{l}\text { Clovers, } \\
\text { pasture } \\
\text { vetches } \\
\text { and be } \\
\text { der. }\end{array}$ & $\begin{array}{l}\text { e grass, } \\
\text { s, pea } \\
\text { an fod- }\end{array}$ & & $\begin{array}{l}\text { rrots, pota- } \\
\text { toes, sugar } \\
\text { beets, man- } \\
\text { golds, turnips. }\end{array}$ \\
\hline $\begin{array}{l}\text { Very high in } \\
\text { protein (above } \\
40 \text { per cent.) }\end{array}$ & $(25$ & $\begin{array}{l}\text { igh in } \\
\text { otein } \\
\text { o per ct.) }\end{array}$ & $\begin{array}{l}\text { Fairly hig } \\
\text { proteir } \\
\text { (12-25 per }\end{array}$ & & $\begin{array}{l}\text { Low in pro- } \\
\text { tein (below } \\
12 \text { per cent) }\end{array}$ \\
\hline $\begin{array}{l}\text { Dried blood. } \\
\text { Meat scraps. } \\
\text { Cotton-seed } \\
\text { meal }\end{array}$ & $\begin{array}{l}\text { Glu } \\
\text { Atla } \\
\text { Lin } \\
\text { Buc } \\
\text { m } \\
\text { Buc } \\
\text { sh } \\
\text { Soja } \\
\text { Gra }\end{array}$ & $\begin{array}{l}\text { en meal. } \\
\text { s meal. } \\
\text { eed meal. } \\
\text { rwheat } \\
\text { ddlings. } \\
\text { rwheat } \\
\text { orts } \\
\text {-bean. } \\
\text { o-gluten. }\end{array}$ & $\begin{array}{l}\text { Malt spro } \\
\text { Dried bre } \\
\text { ers' gra } \\
\text { Gluten fe } \\
\text { Cow pea. } \\
\text { Pea meal. } \\
\text { Wheat sh } \\
\text { Rye short } \\
\text { Oats shor } \\
\text { Wheat mi } \\
\text { dlings. } \\
\text { Wheat br } \\
\text { Low-grad } \\
\text { flour. }\end{array}$ & $\begin{array}{l}\text { its. } \\
\text { v- } \\
\text { ns. } \\
\text { d. } \\
\text { rts. } \\
\text { s. } \\
\text { s. } \\
\text { d- } \\
\text { n. } \\
\text { n. }\end{array}$ & $\begin{array}{l}\text { Wheat. } \\
\text { Barley. } \\
\text { Oats. } \\
\text { Rye. } \\
\text { Corn. } \\
\text { Rice polish. } \\
\text { Rice. } \\
\text { Hominy } \\
\text { chops. } \\
\text { Germ meal. } \\
\text { Oat feeds. }\end{array}$ \\
\hline
\end{tabular}

FEEDING STANDARDS.

Investigations by scientists have brought to light the fact that the different classes of farm animals re- 
quire certain amounts of food materials for keeping the body functions in regular healthy activity; this is known as the maintenance ration of the animal, an allowance of feed which will cause him to maintain his live weight without either gaining or losing, or producing animal products like milk, wool, meat, eggs, etc. If the animal is expected to manufacture these products in addition, it is necessary to supply enough extra food to furnish materials for this manufacture. The food requirements for different purposes have been carefully studied, and we know now with a fair amount of accuracy how much food it takes in the different cases to reach the objects sought. Since there is a great variety of different foods, and almost infinite possible combinations of these, it would not do to express these requirements in so and so many pounds of corn or oats, or wheat bran, but they are in all cases expressed in amounts of digestible protein, carbohydrates and fat. This enables the feeder to supply these food materials in such feeding stuffs as he has on hand or can procure. The feeding standards commonly adopted as basis for calculations of this kind are those of the German scientists, Wolff and Lehmann. Those standards give, then, the approximate amount of dry matter, digestible protein, carbohydrates, and fat which the different classes of farm animals should receive in their daily food in order to produce maximum returns. We have seen that a fair amount of digestible protein in the food is essential in order to obtain good results. The proportion of digestible nitrogenous to digestible nor-nitrogenous food substances therefore becomes important. This proportion is technically known as Nutritive Ratio, and we speak of wide nutritive ratio, when there are six or more times as much digestible carbohydrates and fat in a ration as there is digestible protein, and a narrow ratio, when the proportion of the two kinds of food materials is as I to 6 , or less. 


\section{FEEDING STANDARDS FOR FARM ANIMALS}

(WOLFF-LEHMANN.)

(Per day and per 1000 1bs. live weight.

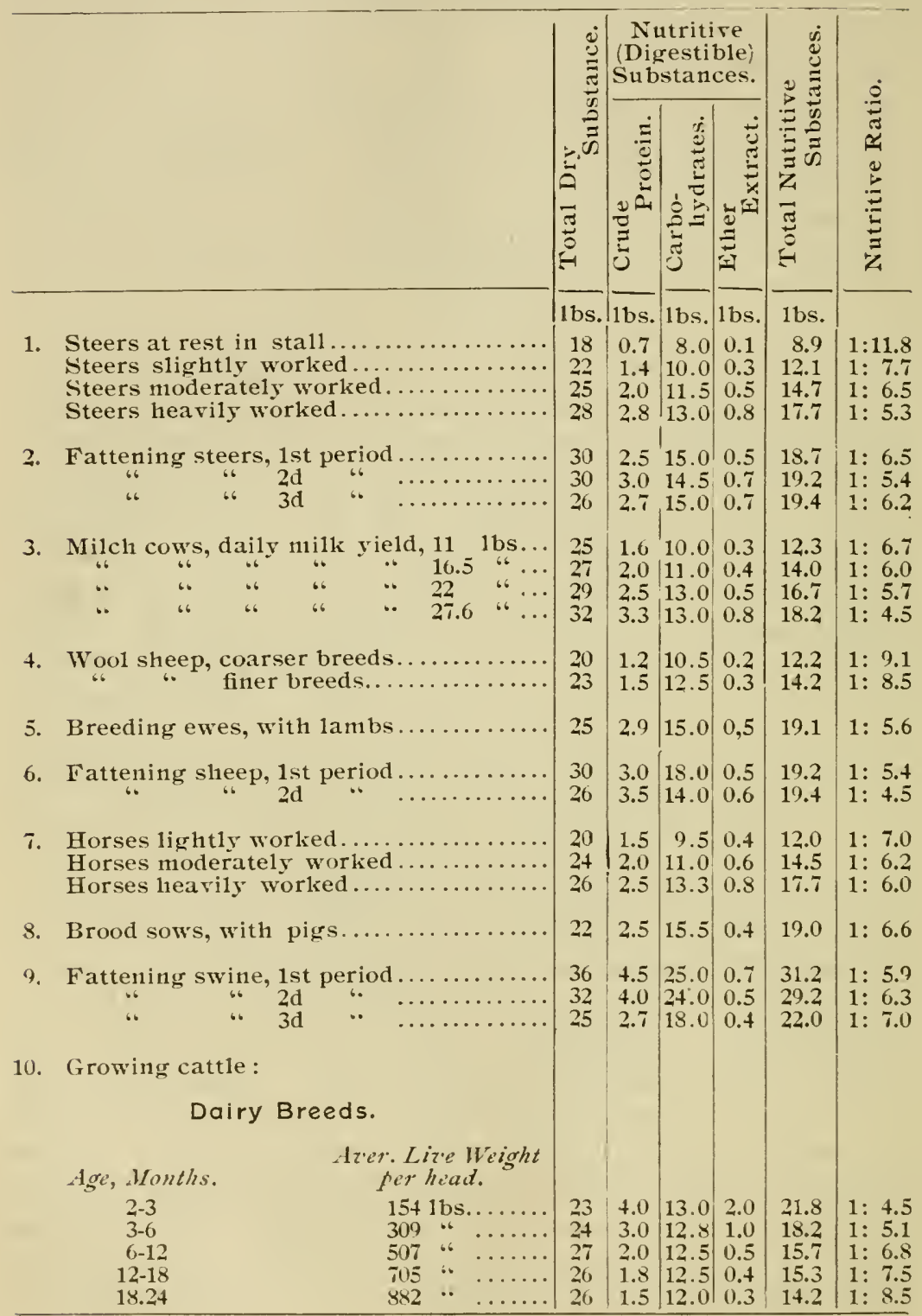


FEEDING STANDARDS FOR FARM ANIMALS.-CONTINUED.

11. Growing cattle:

Beef Breeds.

2-3

3-6,

6-12

$12-18$

$18-24$
Age, Months.

Arcr. Liz'c Weight fer head.

12. Growing sheep :

\section{Wool Breeds.}

$4-6$
$6-8$
$8-11$
$11-15$
$15-20$

13. Growing sheep :

\section{Mutton Breeds.}

$4-6$
$6-8$
$8-11$
$11-15$
$15-20$

14. Growing swine:

\section{Breeding Anlmals.}

$2-3$
$3-5$
$5-6$
$6-8$
$8-12$

15. Growing fat pigs:

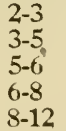

$6016 \mathrm{~s} . \ldots \ldots, 26$

84 “. ....... 26

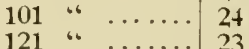

154 “ . . . . 22

\begin{tabular}{cc|c}
1651 b. . . . . . . & 23 \\
331 & 6
\end{tabular}

551 “ $\ldots \ldots \ldots 25$

750 “

$\begin{array}{lllll}937 & \cdots & \ldots & & 24\end{array}$

\begin{tabular}{l|l|l}
4.2 & 13.0 & 2.0 \\
3.5 & 12.8 & 1.5
\end{tabular}

\begin{tabular}{ll|l|l|l}
3.5 & 12.8 & 1.5 \\
3 & 13.5
\end{tabular}

$\begin{array}{llll}2.5 & 13.2 & 0.7\end{array}$

\begin{tabular}{ll|l|l|}
2.0 & 12.5 & 0.5 \\
1.8 & 12.0 & 0.4
\end{tabular}

19.9

17.4

15.7

1: 4.2

1: 4.7

$1: 6.0$

1: 6.8

\begin{tabular}{l|l|l}
1.8 & 12.0 & 0.4
\end{tabular}

1: 7.2

1: 5.0

1: 5.4

1: 6.0

1: 7.0

1: 7.7

\begin{tabular}{l|l|l|l|l}
3.4 & 15.4 & 0.7 & 20.5 & $1: 5.0$ \\
2.8 & 13.8 & 0.6 & 18.0 & $1: 5.4$ \\
1.8 & 11.5 & 0.5 & 14.8 & $1: 6.0$ \\
1.5 & 10.8 & 0.4 & 14.0 & $1: 7.0$ \\
& & & &
\end{tabular}

\begin{tabular}{ll|l|l|l|l}
4.4 & 15.5 & 0.9 & 22.1 & $1:$ & 4.0
\end{tabular}

\begin{tabular}{l|l|l|l|l}
3.5 & 15.0 & 0.7 & 20.2 & $1: 4.8$
\end{tabular}

\begin{tabular}{l|l|l|l|l|l}
3.0 & 14.3 & 0.5 & 18.5 & $1: 5.2$
\end{tabular}

\begin{tabular}{ll|l|l}
2.2 & 12.6 & 0.5
\end{tabular}

$\begin{array}{llll}2.0 & 12.0 & 0.4\end{array}$

$16.0 \quad 1: 6.3$

$15.01: 6.5$

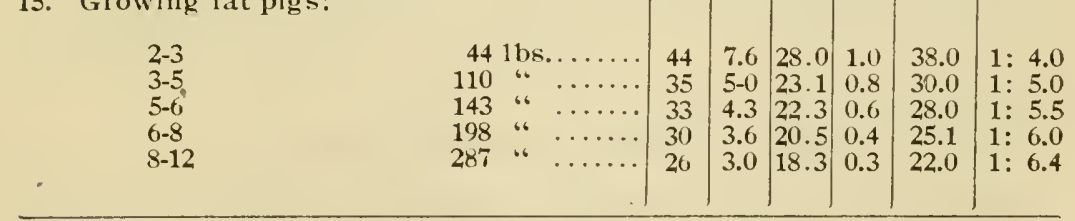


The feeding standards given in the preceding tables may serve as a fairly accurate guide in determining the food requirements of farm animals; and it will be noticed that the amounts are per rooo pounds live weight, and not per head, except as noted in the case of growing animals. They should not be looked upon as infallible guides, which they are not, for the simple reason that different animals differ greatly both in the amounts of food that they consume and in the uses which they are able to make of the food they eat. The feeding standard for milch cows has probably been subjected to the closest study by American experiment station workers, and it has been found in general that the Wolff-Lehmann standard calls for more digestible protein (i. e., a narrower nutritive ratio) than can be fed with economy in most of the dairy sections of our country, at least in the central and northwestern states. On basis of investigations conducted in the early part of the nineties, along this line, Prof. Woll, of Wisconsin, proposed a so-called American practical feeding ration, which calls for the following amounts of digestible food materials in the daily ration of a dairy cow of an average weight of I 000 pounds.

Digestible protein, . . $2.2 \mathrm{lbs}$.

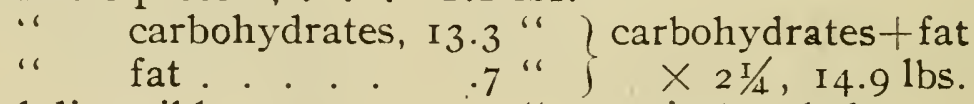

Total digestible matter, . I7. I " protein + carbohy-

Nutritive ratio, . . I:6.9.

$$
\text { drates }+ \text { fat } \times 21 / 4 \text {. }
$$

\section{HOW TO FIGURE OUT RATIONS.}

We shall use the practical American feeding ration as a basis for figuring out the food materials which should be supplied a dairy cow weighing 1000 pounds, in order to insure a maximum and economical production of milk and butter fat from her. We will suppose that a farmer has the following foods at his dis- 
posal: corn silage, mixed timothy and clover hay, and wheat bran; and that he has to feed about forty pounds of silage per head daily, in order to have it last through the winter and spring. We will suppose that he gives his cows in addition five pounds of hay and about six pounds of bran. If we now look up in the tables given on pages ${ }^{8} 8$ to 189 , the amounts of digestible food components contained in the quantities given of these feeds, we shall have:

\section{Total Digestible Total Nut.} dry mtr. Pro. Carb. Efat. dig. mtr. ratio.

40 lbs. corn silage, $10.5 \mathrm{lbs} . \quad .48 \mathrm{lbs} .7 .1 \mathrm{lbs} .7 .58$

\begin{tabular}{lllllll}
5 lbs. mixed hay, & 4.2 & .22 & 2.2 & 2.42 & \\
6 lbs. wheat bran, & 5.3 & .72 & $\frac{2.8}{3.52}$ & \\
\cline { 2 - 3 } & $\overline{20.0}$ & $\overline{1.42}$ & $\overline{12.1}$ & $\overline{13.52}$ & $1: 8.5$
\end{tabular}

We notice that the ration as now given contains too little total digestible matter, there being a deficit of both digestible protein, carbodydrates and fat, it will evidently be necessary to supply at least a couple of pounds more of some concentrated feed, and preferably of a feed rich in protein, since the deficit of this component is proportionally greater than that of the other components. In selecting a certain food to be added and deciding the quantities to be fed the cost of different available foods must be considered. We will suppose that linseed meal can be bought at a reasonable price in this case, and will add two pounds thereof to the ration. We then have the following amounts of digestible matter in the ration:

$$
\begin{gathered}
\text { Total Digestible Total Nutritive } \\
\text { Dry Mtr. Pro. Carb. fat. dig. mtr. Ratio. }
\end{gathered}
$$

Ration as above, 21.0 1bs. 1.42 lbs. 12.1 lbs. $13.52 \quad 1.8 .5$ 21bs. oil meal (O.P.) 1.8

$\begin{array}{rrrrr}\frac{.62}{2.04} & & 1.0 & 1.62 & \\ 2.2 & & 13.1 & 16.14 & 1: 6.4 \\ 2.5 & & 14.1 & 1: 6.9 \\ & & 14.1 & 16.6 & 1: 5.7\end{array}$

$\begin{array}{lllll}\text { Amer. prac. feed'g ration, } & 2,2 & 14.9 & 17.1 & 1: 6.9\end{array}$ Wolff-Lehmann standard,

29,0

2.5

14.1

$1: 5.7$ 
The new ration is still rather light, both in total and digestible food materials; for many cows it might prove effective as it is, while for others it would doubtless be improved by a further addition of some concentrated food medium rich in protein, or if grain feeds are high, of more hay or silage. The feeding rations are not intended to be used as infallible standards that must be followed blindly, nor could they be used as such. They are only meant to be approximate gauges by which the farmer may know whether the ration which he is feeding is of about such a composition and furnishes such amounts of important food materials as are most likely to produce best results, cost of feed and returns in products as well as condition of animals being all considered.

In constructing rations according to the above feeding standards, sereral points must be considered besides the chemical composition and the digestibility of the feeding stuffs; the standards cannot be followed directly without regard to bulk and other properties of the fodder; the ration must not be too bulky, and still must contain a sufficient quantity of roughage to keep up the rumination of the animals, in case of cows and sheep, and to secure a healthy condition of the animals generally. The local market prices of cattle foods are of the greatest importance in determining which foods to buy ; the conditions in the different sections of our great continent differ so great$1 y$ in this respect that no generalizations can be made. Generally speaking, nitrogenous concentrated feeds are the cheapest feeds in the south and in the east, and flour mill, brewery, and starch-factory refuse feeds the cheapest in the northwest.

The tables given on pages i 85 to I 89 will be found of great assistance in figuring out the nutrients in feed rations; the tables have been reproduced from a bulletin published by the Vermont Experiment Station, and are based upon the latest compilations of analyses 
of feeding stuffs. A few rations are given in the following as samples of combinations of different kinds of feed with corn silage that will produce good results with dairy cows. The rations given on page I 42 may also be studied to advantage in making up feed rations with silage for dairy cows. The Experiment Stations or other authorities publishing the rations are given in all cases.

\section{Grain Mixture For Dairy Cows.}

Mixtures to be fed with one bushel of silage and hay, or with corn stover or hay.

\section{Massachusetts Experiment Station.}

1.

100 1bs. bran.

100 1bs. flour middlings.

150 1bs. gluten feed.

Mix and feed 7 quarts daily.

3.

100 1bs. bran.

100 1bs. flour middlings.

$1001 \mathrm{bs}$. gluten or cottonseed meal. Mix and feed 7 to 8 quarts daily.

3.

100 1bs. cottonseed or gliten nea1.

150 1bs. cor11 and cob mea1.

1001 bs. bran.

Mix asd feed 7 to 8 quarts daily.
2.

1001 bs, bran or mixed feed.

150 1bs. gluten feed.

Mix and feed 9 quarts daily.

4.

2001 bs. malt sprouts.

100 1bs. bran.

1001 bs. gluten feed.

Mix and feed 10 to 12 quarts daily.

6.

125 1bs, gluten feed.

$1001 \mathrm{bs}$. corn and cob niea1.

Mix and feed 5 to 6 quarts daily.

New Jersey Experiment Station: 40 lbs. corn silage, 5 lbs. gluten feed, 5 lbs. dried brewers' grains, 2 lbs. wheat bran.

(2) 35 lbs. corn silage, 5 lbs. mixed hay, 5 lbs. wheat bran, 2 lbs. each of oil meal, gluten meal and hominy meal.

(3) 40 lbs. corn silage, 5 lbs. clover hay, 3 lbs. wheat bran, 2 lbs. malt sprouts, I $1 \mathrm{~b}$. each of cottonseed meal and honiny meal. 
(4) 40 lbs. corn silage, 4 lbs. dried brewers' grains, 4 lbs. wheat bran, 2 lbs. oil meal.

Maryland Experiment Station: 40 lbs. silage, 5 lbs. clover hay, $9 \mathrm{lbs}$. wheat middlings, and I lb. gluten meal.

(2) 30 lbs. silage, 8 lbs. corn fodder, 6 lbs. cow pea hay, 3 lbs. bran, 2 lbs. gluten meal.

Michigan Experiment Station: (I) 4olbs. silage, 8 lbs. mixed hay, 8 lbs. bran, 3 lbs. cottonseed meal.

(2) $30 \mathrm{lbs}$ silage, $5 \mathrm{lbs}$. mixed hay, $4 \mathrm{lbs}$. corn meal, 4 lbs- bran, 2 lbs cottonseed meal, 2 lbs. oil meal.

(3) 30 lbs. silage, Io lbs. clover hay, 4 lbs. bran, 4 lbs. corn meal, 3 lbs. oil meal,

(4) $30 \mathrm{lbs}$. silage, $4 \mathrm{lbs}$. clover hay, io $1 \mathrm{bs}$. bran.

Kansas Experiment Station: (I) Corn silage 40 lbs., Io lbs. prait ie hay or millet, $4 \frac{1}{2} 2 \mathrm{lbs}$. bran, $3 \mathrm{lbs}$. cottonseed meal.

(2) $40 \mathrm{lbs}$. corn silage, Io lbs. corn fodder, $4 \mathrm{lbs}$. bran, 2 lbs. Chicago gluten meal, 2 lbs. cottonseed meal.

(3) 40 lbs. corn silage, 5 lbs. sorghum hay, $3 \mathrm{lbs}$. corn, I $1 / 2 \mathrm{lbs}$. bran, $3 \mathrm{lbs}$. gluten meal, $\mathrm{I} / 2 \mathrm{lbs}$. cotton seed meal.

(4) $30 \mathrm{lbs}$. corn silage, Io lbs. millet, $4 \mathrm{lbs}$. corn, I lb. gluten meal, 3 lbs. cottonseed meal.

(5) 30 lbs. corn silage, I $5 \mathrm{lbs}$. fodder corn, $2 \frac{1}{2} \mathrm{lbs}$. bran, 3 lbs. gluten meal, I $1 / 2$ lbs. cottonseed meal.

(6) $30 \mathrm{lbs}$. corn silage, I $5 \mathrm{lbs}$. fodder corn, $2 \mathrm{I} / 2$ lbs. bran, 3 lbs gluten meal, I $1 / 2$ lbs. cottonseed meal.

(6) $30 \mathrm{lbs}$. corn silage, Io lbs. oats straw, $2 \mathrm{lbs}$. oats, 4 lbs. bran, 2 lbs. gluten meal, 2 lbs. cottonseed meal.

(7) $20 \mathrm{lbs}$. corn silage, $20 \mathrm{lbs}$. alfalfa, $3 \mathrm{lbs}$. corn.

(8) I 5 lbs. corn silage, 20 lbs. alfalfa, 5 lbs. Kafir corn.

(9) 20 lbs. corn silage, I 5 lbs. alfalfa, 4 lbs. corn, 3 lbs. bran. 
(IO) 40 lbs. corn silage, 5 lbs. alfalfa, 3 lbs. corn, 3 lbs. oats, 2 lbs. O. P. linseed meal, I 1b. cottonseed meal.

Tennessee Experiment Station: 30 lbs. silage, Io lbs. clover or cow pea hay, 5 lbs. wheat bran, 3 lbs. of corn, 2 lbs. cottonseed meal.

North Carolina Experiment Station: (I) 40 lbs. corn silage, Io lbs. cottonseed hulls, $5 \mathrm{lbs}$. cottonseed meal.

(2) 50 lbs. corn silage, 5 lbs. orchard grass hay, $4^{1 / 2}$ lbs. cottonseed meal.

(3) 30 lbs. corn silage, Io lbs. alfalfa, 6 lbs. wheat bran, 5 lbs. cottonseed hulls.

(4) 40 lbs. corn silage, I 5 lbs. cow pea vine hay.

(5) $40 \mathrm{lbs}$. corn silage, $6 \mathrm{lbs}$. wheat bran, $6 \mathrm{lbs}$. field peas ground.

(6) 40 lbs. corn silage, 4 lbs. cut corn fodder, 3 lbs. ground corn, 4 lbs bran, I lb. cottonseed meal (ration $f \in d$ at Biltmore Estate to dairy cows. Silage is fed to steers and cows, and corn, peas, teosinte, cowpeas, millet and crimson clover are used as silage crops. These crops ate put into the silo in alternate layers. "Will never stop using the silo and silage").

South Carolina: 30 lbs. corn silage, 6 lbs. bran, 3 1bs. cottonseed meal, i 2 lbs. cottonseed hulls.

Georgia Experiment Station: 40 lbs. corn silage, I 5 lbs. cow-pea hay, 5 lbs. bran.

Ontario Agr. College: 45 lbs. corn silage, 6 lbs. clover hay, 8 lbs. bran, 2 lbs. barley.

Nappan Experiment Station (Cánada) : 3o lbs. corn silage, 20 lbs. hay, 8 lbs. bran and meal.

The criticism may properly be made with a large number of the rations given in the preceding, that it is only in case of low prices of grain or concentrated feeds in general, and with good dairy cows, that it is possible to feed such large quantities of grain profitably as those often given. In the central and northwestern states it will not pay to feed grain heavily 
with corn at fifty cents a bushel, and oats at thirty cents a bushel or more. In times of high prices of feeds, it is only in exceptional cases that more than six to eight pounds of concentrated feeds can be fed with economy per head daily. Some few cows can give proper returns for more than this quantity of grain eren when this is high, but more cows will not do so. The farmer shonld aim to grow protein foods like clover, alfalfa, peas, etc., to as large extent as practicable, and thus reduce his feed bills.

Average Composition of Silage Crops of DifFERENT KINDS, IN PER CENT.

\begin{tabular}{|c|c|c|c|c|c|c|}
\hline & Water & Ash & $\begin{array}{l}\text { Crude } \\
\text { protein }\end{array}$ & $\begin{array}{l}\text { Crude } \\
\text { fiber }\end{array}$ & $\begin{array}{l}\text { Nitrogen } \\
\text { froe ez- } \\
\text { tract }\end{array}$ & $\begin{array}{r}\text { Ether } \\
\text { extract }\end{array}$ \\
\hline Corn silage & & & & & & \\
\hline mature corn & 73.7 & 1.6 & 2.2 & 6.5 & 15.1 & .9 \\
\hline immature corı & 79.1 & 1.4 & 1.7 & 6.0 & 11.0 & .8 \\
\hline ears removed & 80.7 & 1.8 & 1.8 & 5.6 & 9.5 & .6 \\
\hline Clover silage & 72.0 & 2.6 & 4.2 & 8.4 & 11.6 & 1.2 \\
\hline Soja bean silage & 74.2 & 2.8 & 4.1 & 9.7 & 6.9 & 2.2 \\
\hline Cow-pea vine silage & 79.3 & 2.9 & 2.7 & 6.0 & 7.6 & 1.5 \\
\hline Field-pea vine silage & $5(1.0$ & 3.6 & 5.9 & I3.0 & 26.0 & 1.6 \\
\hline $\begin{array}{l}\text { Corn cannery refuse- } \\
\text { husks }\end{array}$ & 83.8 & .6 & 1.4 & 5.2 & 7.9 & 1.1 \\
\hline $\begin{array}{l}\text { Corn cannery refuse- } \\
\text { cobs }\end{array}$ & 74.1 & .5 & 1.5 & 7.9 & 14.3 & 1.7 \\
\hline Pea cannery refuse & 768 & 1.3 &, 2.8 & 6.5 & 11.3 & 1.3 \\
\hline Sorghum silage & 76.1 & 1.1 & .8 & 6.4 & 15.3 & 3 \\
\hline Corn-soja bean silage & 760 & 2.4 & 2.5 & 7.2 & 11.1 & .8 \\
\hline Millet-soja bean silage & 79.0 & 2.8 & 2.8 & 7.2 & 7.2 & 1.0 \\
\hline Rye silagre & 811.8 & 1.6 & 2.4 & 58 & 9.2 & .3 \\
\hline Apple pomace silage & $8=.0$ & .6 & 1.2 & 3.3 & 8.8 & 1.1 \\
\hline $\begin{array}{l}\text { Cow-pea and soja } \\
\text { bean mixed }\end{array}$ & 698 & 45 & 3.8 & 9.5 & 11.1 & 1.3 \\
\hline Corn-kernels & 41.3 & 1.0 & 6.0 & 1.5 & 46.6 & 3.6 \\
\hline $\begin{array}{l}\text { Mixed grasses } \\
\text { (rowen) }\end{array}$ & 18.4 & 7.1 & 10.1 & 22.8 & 36.0 & 5.7 \\
\hline $\begin{array}{l}\text { Brewers' grain } \\
\text { silage }\end{array}$ & 69.8 & 1.2 & 6.6 & 4.7 & 15.6 & 2.1 \\
\hline
\end{tabular}

The above table gives actual chemical analyses of 
the products mentioned and includes the entire roo per cent. of the contents and weight. The following table, compiled by the Editors of Hoard's Dairymen, Fort Atkinson, Wis., shows the average amounts of digestible nutrients in the more common American fodders, grains and by-products, and is the table that should be used in formulating rations. The tables give the amounts of digestible nutrients contained in IoO lbs. in pounds, and the figures can, therefore, be taken as per cents in figuring out the amount of digestible nutrients in any given amount of food material, and it is by such methods that the tables given on pages $S_{5}$ to ISg are obtained.

\section{ANALYSES OF FEEDING STUFFS.}

TAble Showing Average Aliounts of Digestible Nutrients IN THE MORE COMIION AMERICAN Fodders, Grains and By-Products.

Complied by the Editors of Hoard's Dairyman, Fort Atkinson, Wis.

\begin{tabular}{|c|c|c|c|c|}
\hline \multirow[b]{2}{*}{ NAME OF FEED. } & \multirow{2}{*}{ 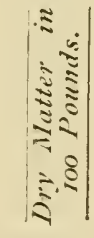 } & \multicolumn{3}{|c|}{$\begin{array}{l}\text { Digestible Nutrients } \\
\text { in } 100 \text { Pounds. }\end{array}$} \\
\hline & & 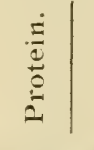 & 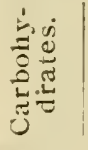 & 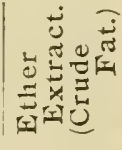 \\
\hline GREEN FODDERS. & Lbs. & Lbs. & Lbs. & Lbs. \\
\hline Pasture Grasses mixed . . . . . & 20.0 & 2.5 & 10.2 & \\
\hline Fodder Corn ............... & .20 .7 & 1.0 & 11.6 & 0.4 \\
\hline Sorgum $\ldots \ldots \ldots$ & 20.6 & 0.6 & 12.2 & 0.4 \\
\hline Red Clover................ & 29.2 & 2.9 & 14.8 & 0.7 \\
\hline 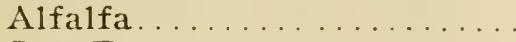 & .28 .2 & 3.9 & 12.7 & 0.5 \\
\hline Cow Pea . & .16 .4 & 1.8 & 8.7 & 0.2 \\
\hline Soja Bean.. & 24.9 & 3.2 & 11.0 & 0.5 \\
\hline Oat Fodder. & .37 .8 & 2.6 & 18.9 & $1 .($ \\
\hline Rye!Fodder........ . & .23 .4 & 2.1 & 14.1 & 0.4 \\
\hline Rape ..... & .14 .0 & 1.5 & 8.1 & 0.2 \\
\hline Peas and Oats .......... & .16 .0 & 1.8 & 7.1 & 0.2 \\
\hline Beet Pulp............. & .10 .2 & 0.6 & 7.3 & \\
\hline
\end{tabular}




NAME OF FEED.

SILAGE. Lbs. Lbs. Lbs. Lbs.

Corn .................... 20.9

Corn, Wisconsin analyses....... . 26.4

Sorghum ............... . . . . 23.9

Red Clover ................. 28.0

Alfalfa ... . . . . . . . . . . . 27.5

Cow Pea................... 20.7

Soja Bean .............. 25.8 $\begin{array}{lll}0.9 & 11.3 & 0.7\end{array}$

$\begin{array}{lll}1.3 & 14.0 & 0.7\end{array}$

$\begin{array}{lll}0.6 & 14.9 & 0.2\end{array}$

$2.0 \quad 13.5 \quad 1.0$

$\begin{array}{lll}3.0 & 8.5 & 1.9\end{array}$

$\begin{array}{lll}1.5 & 8.6 & 0.9\end{array}$

$\begin{array}{lll}2.7 & 8.7 & 1.3\end{array}$

\section{DRY FODDER AND HAY.}

Corn Fodder

Corn Fodder, Wis. analyses ......7.7.0

Corn Stover

Sorghum Fodder.

Corn Stover

Red Clover.................. . 84.7

Alfalfa ....................91.6

Barley .................. 85.2

Blue Grass... . . . . . . . . . . . . . .78.8

Cow Pea. ................. 89.3

Crab Grass ........ . . . . . . . 82.4

Johnson Grass................ 87.7

Marsh Grass . . . . . . . . . . . . . . 88.4

Millet..... ... . .......... 92.3

Oat Hay...... ......... . . . 91.1

Oat and Pea Hay . . . . . . . . . . 85.4

Orchard Grass ... ........... . 90.1

Prairie Grass........... . . . . . 87.5

Red Top . . . . . . . . . . . . . . 91.1

Timothy ........... . . . . . 86.8

Timothy and Clover ... . . . . . 85.3

Vetch.... . . . . . . . . . . . 88.7

White Daisy
2.5

34.6

$3.7 \quad 40.4$

$1.7 \quad 32.4$

$1.5 \quad 37.3$

$6.8 \quad 35.8$

$11.0 \quad 39.6$

$6.2 \quad 46.6$

$4.8 \quad 37.3$

$10.8 \quad 38.6$

$\begin{array}{ll}5.7 & 39.7\end{array}$

$2.4 \quad 47.8$

$2 \cdot 4 \quad 29.9$

4.5

4.3

9.2

4.9

3.5

4.8

2.8

4.8

12.9

3.8

$\begin{array}{llll}85.0 & 3.8 & 40.7 & 1.2\end{array}$

STRAW.

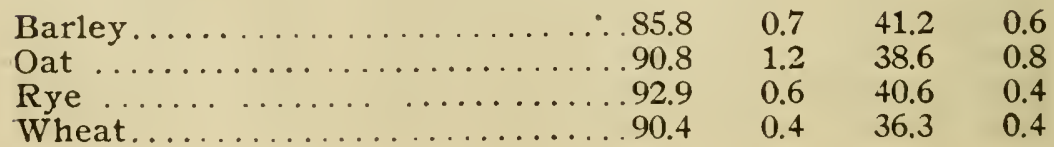




\begin{tabular}{|c|c|c|c|}
\hline & \multicolumn{3}{|c|}{$\begin{array}{l}\text { Digestible Nutrients } \\
\text { in 100 Pounds. }\end{array}$} \\
\hline & 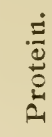 & 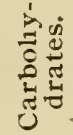 & 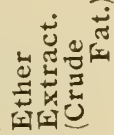 \\
\hline
\end{tabular}

ROOTS AND TUBERS.

Lbs.

Libs.

Lbs.

Libs.

Artichokes... . . . . . . . . . . . 20.0

2.0

16.8

0.2

Beets common

13.0

Beets, sugar.

13.5

1.2

8.8

0.1

Carrots . .

11.4

1.1

10.2

0.1

Mangels

9.1

Parsnips

11.7

Potatoes

21.1

Rutabagas

11.4

Turnips.

9.5

0.8

7.8

0.2

Sweet Potatoes

29.0

1.1

1.6

5.4

0.1

0.9

11.2

0.2

1.0

16.3

0.1

1.0

8.1

0.2

0.9

7.2

0.2

$22.2 \quad 0.3$

GRAIN AND BY-PRODUCTS.

Barley

89.1

8.7

Brewers' Grains, dry . . . . . . . 91.8

Brewers' Grains, wet ........24.3

Malt Sprouts . . . . . . . . . . . . 89.8

Buckwheat................. 87.4

Buckwheat Bran .............89.5

Buckwheat Middlings .........87.3

Corn

89.1

Corn and Cob Mea1...........89.0

Corn Cob...................899.3

Corn Bran................. 90.9

Atlas Gluten Mea1............ 92.0

Gluten Meal................. 88.0

Germ Oil Mea1. . . . . . . . . . . . . 990.0

Gluten Feed .............. . 90.0

Hominy Chop ... . . . . . . . . 88.9

Starch Feed, wet.............34.6

Cotton Seed..................8. 89.7

Cotton Seed Meal. . . . . . . . . . . 91.8

Cotton Seed Hulls . . . . . . . . . . . . 88.9

Cocoanut Meal . . . . . . . . . . 89.7

Cow Peas.................... . . 85.2

Flax Seed

.90 .8

Oil Meal, old process.

90.8

15.7

65.6

1.6

3.9

36.3

5.1

18.6

9.3

1.4

7.7

37.1

1.7

7.4

49.2

1.8

22.0

30.4

1.9

7.9

33.4

5.4

6.4

66.7

4.3

0.4

63.0

3.5

7.4

52.5

0.3

24.6

59.8

4.6

32.1

38.8

11.5

20.2

41.2

2.5

23.3

44.5

8.8

7.5

50.7

2.7

5.5

55.2

12.5

21.7

6.8

37.2

30.0

2.3

0.3

16.9

17.3

$\begin{array}{lll}15.6 & 38.3 & 10.5\end{array}$

$\begin{array}{lll}18.3 & 54.2 & 1.1\end{array}$

$\begin{array}{lll}20.6 & 17.1 & 29.0\end{array}$

$\begin{array}{lll}29.3 & 32.7 & 7.0\end{array}$

Oil Meal, new process. .89 .9

$28.2 \quad 40.1$

2.8 


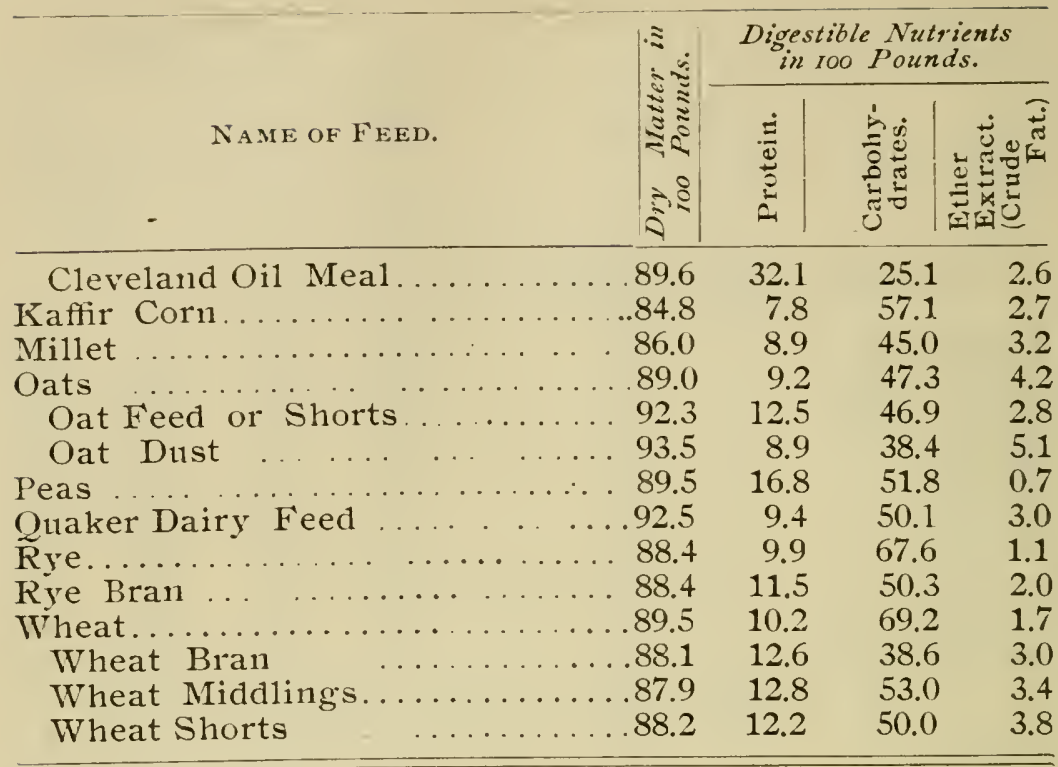

WEIGHT OF CONCENTRATED FEEDS.

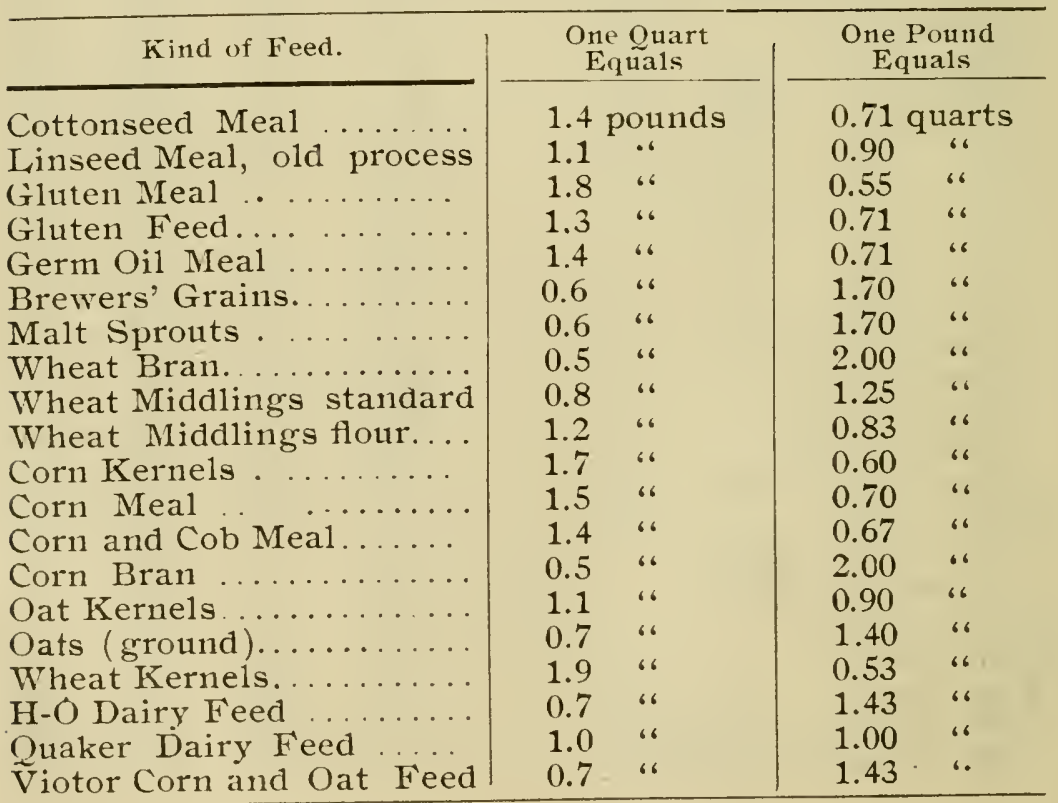


SOILING CROPS ADAPTED TO NOR'THERN NEW ENGLAND STATES. (Lindsey)

(For 10 cows' entire soiling.)

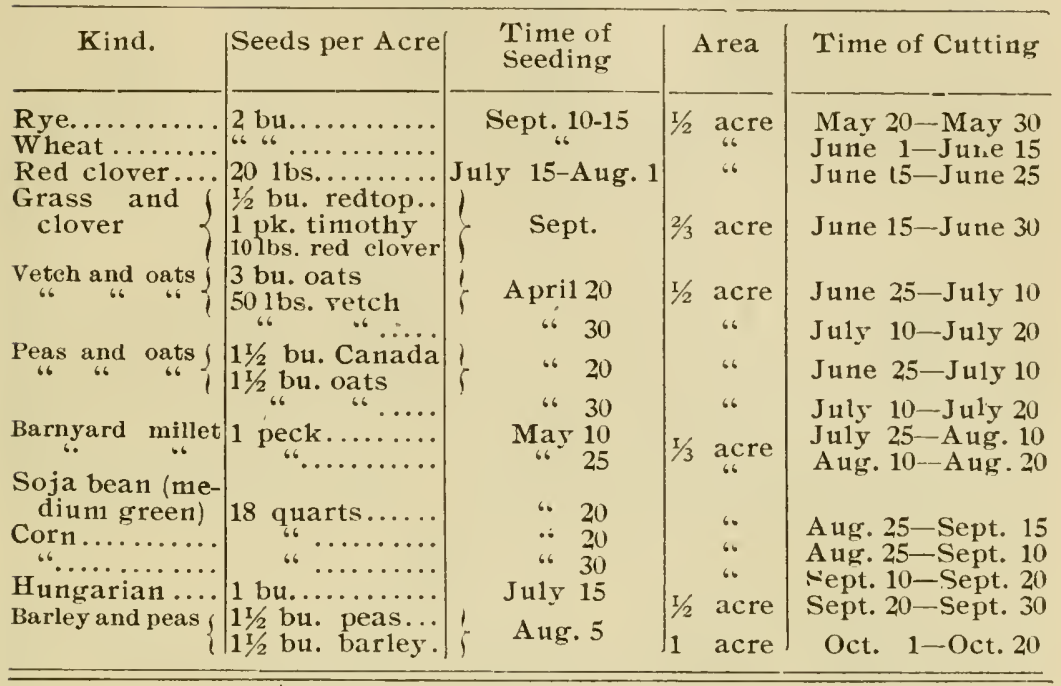

Time of Planting and Feeding Solling Crops. (Phelps.)

\begin{tabular}{|c|c|c|c|}
\hline Kind of Fodder. & $\left|\begin{array}{c}\text { A nount of } \\
\text { Seed } \\
\text { per Acre. }\end{array}\right|$ & $\begin{array}{l}\text { Approxi- } \\
\text { mate Tine } \\
\text { of Seeding. }\end{array}$ & $\begin{array}{l}\text { Approximate } \\
\text { Time of Feeding. }\end{array}$ \\
\hline 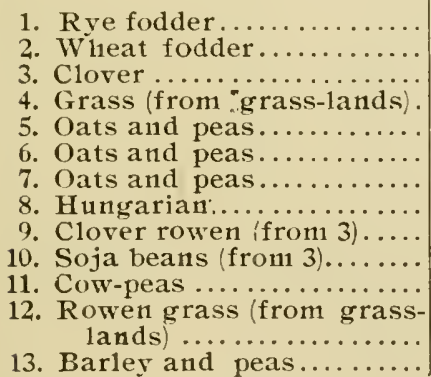 & 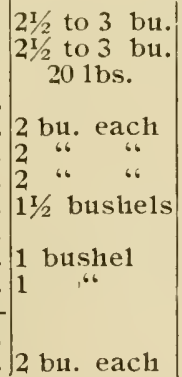 & $\begin{array}{l}\text { Sept. } 1 \\
\text { Sept. 5-10 } \\
\text { July } 20-30 \\
\text { Apri1 } 10 \\
\text {. } \quad 20 \\
\text { June } 1 \\
\text { May 25 } \\
\text { June 5-10 } \\
\text { Aug. 5-10 }\end{array}$ & $\begin{array}{l}\text { May } 10-20 \\
\text { May 20, June } 5 \\
\text { June } 5-15 \\
\text { June } 15-25 \\
\text { June } 25, \text { July } 10 \\
\text { Ju1y } 10-20 \\
\text { "6 } 20, \text { Aug. } 1 \\
\text { Augr. } 1-10 \\
\text { " } 10-20 \\
\quad 20, \text { Sept. } 5 \\
\text { Sept. } 5-20 \\
\text { " } 20-30 \\
\text { Oct. } 1-30\end{array}$ \\
\hline
\end{tabular}

The dates given in the table apply to Central Connecticut and regions under approximately similar conditions. 
A FEEDERS' GUIDE.

Cost of a Pound of Digestible Dry Matter in DIFFERENT FEeding STUFFs.

\begin{tabular}{|c|c|c|c|c|c|}
\hline 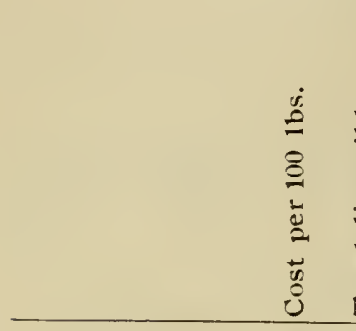 & 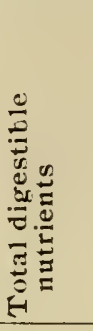 & 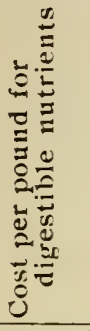 & 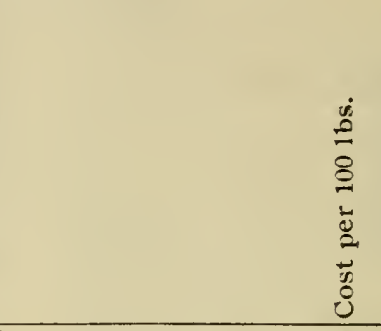 & 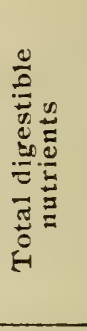 & 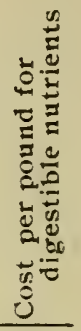 \\
\hline Feec & $1 \mathrm{bs}$. & cts. & Feeds & $1 \mathrm{bs}$. & cts. \\
\hline Corn meal. & 79.5 & 1.01 & Mixed (wheat & & \\
\hline Cob meal. & 71.3 & 1.09 & al 1.20 & & .50 \\
\hline Oats ...... & 67.0 & 1.34 & Linseed meal O.P.1.30 & 77.1 & 1.69 \\
\hline Provender. & 72.3 & 1.18 & " $\quad$ "N.P.1.30 & & \\
\hline Quaker dairy feed 0.85 & 60.9 & 1.40 & Flax meal .....1.30 & & \\
\hline H. O. dairy feed1.00 & 63.7 & 1.57 & $\begin{array}{l}\text { Chicago gluten } \\
\text { meal ......... } 1.20\end{array}$ & & \\
\hline ed0.85 & 70.4 & 1.21 & $\begin{array}{c}\text { Cream gluten } \\
\text { meal } \\
\ldots\end{array} \ldots 1.20$ & 81. & \\
\hline Hominy chop. . 0.90 & 88.8 & 1.01 & $\begin{array}{l}\text { King gluten mea11.20 } \\
\text { Buffalo gluten }\end{array}$ & & \\
\hline Wheat Bran ....0.85 & 57.9 & 1.47 & $\begin{array}{l}\text { feed } \\
\text { Diamond gluten }\end{array}$ & 80.1 & \\
\hline Wheat Middlings 0.95 & 70.6 & 1.35 & feed ......... 1.00 & 82.3 & \\
\hline
\end{tabular}


IN VARYING WEIGHTS OF FEED, IN POUNDS.

Note.-These tables save calculations of percentages. since. the weights and contents being given in pounds. it is only necessary to find the kind and desired amount of a certain feed. and the table gives the exact food contents in pounds. as in the first table. 15 1hs. of Green Oat Fodder contains 5.7 lbs. of dry matter. 0.35 ibs. of protein and 3.1 lbs' carbohydrates.

\begin{tabular}{|c|c|c|c|c|c|c|c|c|c|}
\hline $\begin{array}{l}\text { Pounds of } \\
\text { fodder }\end{array}$ & 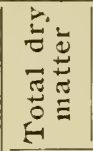 & $\begin{array}{l}\frac{\Xi}{0} \\
\frac{0}{0} \\
0\end{array}$ & 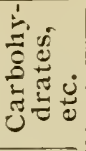 & 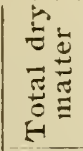 & 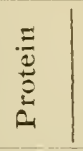 & 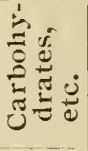 & تُّ & $\begin{array}{l}\frac{5}{0} \\
\frac{0}{0} \\
\text { के }\end{array}$ & 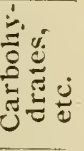 \\
\hline Grasses & \multicolumn{3}{|c|}{ Pasture Grass : :4.8 } & \multicolumn{3}{|c|}{ Timothy Grass, 1:14.3 } & \multicolumn{3}{|c|}{ Ey. Blue Grass, 1:9.2 } \\
\hline $21 / 2 \ldots \ldots$ & 0.5 & 0.06 & 0.3 & 1.0 & 0.04 & 0.5 & 0.9 & 0.05 & 0.5 \\
\hline 5 & & & 0.6 & 1.9 & & & 1.8 & & 0.9 \\
\hline 10 & & & 1.1 & 3.8 & & & 3. & & 1.8 \\
\hline & & & 1.7 & 5.8 & & & 5.2 & & 2.7 \\
\hline & & & 2.2 & 7.7 & & & 7. & & .7 \\
\hline & & & 2. & 9.6 & & & & & 4.7 \\
\hline & & & 3.3 & .5 & & & U. & & 5.5 \\
\hline & & & 3.9 & & & & & & 6.4 \\
\hline 10 & 8.0 & & 4.4 & 15.4 & 0.60 & $1+.0$ & $1+.0$ & 0.80 & 7.3 \\
\hline Green Fodders & \multicolumn{3}{|c|}{ GreenFodderCorn 1:11.7 } & \multicolumn{3}{|c|}{ Green Oat Fodder, 1:8.7 } & \multicolumn{3}{|c|}{ Gr'a Rye Fodder.1:7.2 } \\
\hline $21 / 2 \ldots \ldots$ & & & 0.3 & 0.9 & & & & & 0.4 \\
\hline 5 & & & 0.6 & 1.9 & & & ]. & & 0.7 \\
\hline 0 & & & & 3.8 & & & & & 1.5 \\
\hline & & & 1. & 5.7 & & & & & 2.3 \\
\hline & & & & 7.6 & & & 4. & & $3 .($ \\
\hline & & & 3. & .5 & & & & & .8 \\
\hline & & & 3.9 & .3 & & & & & 4.5 \\
\hline & & & 4. & & & & & & 5. \\
\hline 40 & & & .2 & 5.1 & & 8.3 & 9.4 & 0.84 & 6.0 \\
\hline Green Fodders & \multicolumn{3}{|c|}{ Oats and Peas, $1: 4.2$} & \multicolumn{3}{|c|}{ Barley and Peas, $1: 3.2$} & \multicolumn{3}{|c|}{ Red Clover green 1:5.7 } \\
\hline $21 / 2 \ldots \ldots \ldots$ & & & 0.3 & 0.5 & & 0.2 & & & 0.4 \\
\hline 5 & & & & 1.0 & & & & & 0.8 \\
\hline & & & & & & & & & 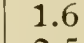 \\
\hline & & & 1. & .1 & & & & & 2. \\
\hline & & & 2. & 4.1 & & & & & 3. \\
\hline & & & 2. & .2 & & & & & . \\
\hline & & & & & & & & & 4. \\
\hline & & & & & & 3. & & & 5. \\
\hline $40 \quad \ldots \ldots \ldots$ & & & 4.6 & 8.2 & & 3.6 & 1.8 & 1.16 & 6. \\
\hline Green Fodders & \multicolumn{3}{|c|}{ Corn Silage, $1: 14.8$} & \multicolumn{3}{|c|}{ Ornstover Silage,l:16.6 } & \multicolumn{3}{|c|}{ Clover Silage, $1: 4.7$} \\
\hline $21 / 2 \ldots \ldots$ & & & 0.4 & & & & & & $0.3^{3}$ \\
\hline 5 & & & & & & & & & 0. \\
\hline & & & 1. & ]. & & & 2 & & 1. \\
\hline & & & 2. & & & & & & 1. \\
\hline & & & 3. & & & 2. & 5. & & 2. \\
\hline & & & 4. & & & 2. & 7. & & 3. \\
\hline & 7.9 & & 5. & 5.8 & & & & & 3. \\
\hline & 9.2 & & 6.2 & & & 3. & 9.8 & & $\because$ \\
\hline$\cdots$ & 10.5 & 0.48 & 7.1 & 7.7 & 0.24 & 4.0 & 11.2 & 1.08 & 5. \\
\hline
\end{tabular}


I 86

READY REFERENCE TABLES-CONTINUED.

\begin{tabular}{|c|c|c|c|c|c|c|c|c|c|c|}
\hline & & 忢 & $\begin{array}{c}\Xi \\
0 \\
0 \\
0 \\
01\end{array}$ & 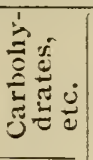 & 岂 & 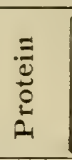 & 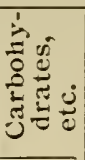 & 莺苞 & $\frac{\pi}{0}$ & 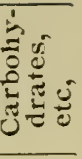 \\
\hline & Roots & Po: & oes, 1: & 17.3 & Suga & Beets, & $: 6.8$ & & ts, 1 : & \\
\hline $21 / 2$ & & 05 & 0.02 & 0.4 & 0.3 & 0.04 & 0.3 & 0.3 & 0.03 & 0.2 \\
\hline 5 & & 1. $\mathrm{L}$ & 0. & 0.8 & & 0. & 0. & 0. & & \\
\hline 10 & & 2.1 & 0.0 & 1.6 & 1.4 & 0.16 & 1.1 & 1.1 & & \\
\hline 5 & & 3.2 & 0.1 & 2.3 & 2.0 & 0. & 1.7 & 1. & & 1.4 \\
\hline 0 & & 4.2 & & 3.1 & 2.7 & 0.32 & 2.2 & 2.3 & & 1.9 \\
\hline 5 & & 5.3 & 3 & 3.9 & & & 2. & 2.9 & & 2.4 \\
\hline 0 & & 6. & 0.2 & 4.7 & & 0. & 3. & 3. & & y \\
\hline 5 & & 7.4 & $0 . ?$ & 5.4 & 4.7 & 0.56 & 3.8 & 4.0 & & 3.4 \\
\hline 0 & & 8.4 & 0.36 & 6.2 & 5.4 & 0.64 & 4.4 & +.0 & & \\
\hline & Roo & Mangel & 7 urtze! & $s, 1: 4.9$ & Rut & agas, & $: 8.6$ & & & \\
\hline $21 / 2$ & & 0.2 & 0.0 & 0.1 & 0.3 & & 0.2 & 0.2 & & 0.2 \\
\hline 5 & & 0. & & 0. & 0.5 & & 0 & & & 4 \\
\hline 10 & & 0.9 & 0.11 & 0.5 & 1.1 & $0 \cdot 10$ & 0.9 & 1.0 & & 0.8 \\
\hline & & 1.4 & & 0.8 & & & 1. & 1.2 & & 2 \\
\hline 0 & & 1,8 & 0.2 & 1.1 & 2.3 & 0.20 & 1.7 & 1.9 & & 1.5 \\
\hline 5 & & 2.3 & 0. & & 2.9 & 0. & 2.2 & 2.4 & & 1.9 \\
\hline & & 2.7 & 0.3 & 1.6 & 3.4 & & 2.6 & 2. & & 2.3 \\
\hline & & 3.2 & & 1.9 & 4.0 & 0 & 3.0 & 3.3 & & 2.7 \\
\hline 0 & . & 3.6 & 0.44 & 2.2 & 4.6 & 1.40 & 3.4 & .8 & 0.40 & 3.1 \\
\hline & Milk & & silk, I & & & mills, & 1.7 & & & \\
\hline $21 / 2$ & & & 7 & 0.1 & & & & II? & & 0.1 \\
\hline 5 & & & 0.15 & 0.3 & 0.5 & 19 & 0. & & & \\
\hline 0 & & 0.9 & 0.29 & 0.6 & 1.0 & & 0.6 & & & 0 . \\
\hline 5 & & 1. & & 0. & & & 1. & & & 0.8 \\
\hline 0 & & 1.9 & 0.58 & 1.2 & 2.0 & & 1. & 1.2 & & 1.0 \\
\hline 25 & & 2.4 & 0.7 & 1.6 & 2.5 & & & 1. & & 1.3 \\
\hline 0 & & 2.8 & 0.8 & 1.8 & 3. & & 1. & 1. & & 1.6 \\
\hline 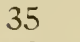 & & 3.2 & & 2.1 & & & 2. & 20 & & 1.8 \\
\hline 40 & $\ldots$ & 3.7 & 1.16 & 2.4 & 4.0 & 1.52 & 2.6 & 2.5 & 0.24 & 2.1 \\
\hline & Hay & Mix & Elay, I & 10.0 & $\operatorname{Timo}$ & Ely, & $: 16.5$ & $\mathrm{Bg} . \mathrm{Blu}$ & 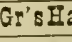 & $1: 10$ \\
\hline $21 / 2$ & & 2.1 & 0.1 & 1.1 & 2.2 & & 1. & 1. & & 1.0 \\
\hline 5 & & 4.2 & 0.2 & 2.2 & & & 2.3 & 3. & & 2.0 \\
\hline $71 / 2$ & & 6.4 & 0.33 & 3.3 & 6.5 & & 3.5 & 5. & & 3.0 \\
\hline 10 & & $8.5^{\circ}$ & 0.4 & 4.4 & & & 4.6 & & & 3.9 \\
\hline $12 \mathrm{I} / 2$ & & 10.6 & & 5.5 & & & 5.8 & & & 4.9 \\
\hline 15 & & 12.7 & 0.66 & 6.6 & & 42 & 6.9 & & & 5.9 \\
\hline $17 \mathrm{I} / 2$ & & & & 7.7 & & & 8.1 & & & 6.9 \\
\hline 20 & & 16.9 & 0.88 & 8.8 & & 0.56 & 9.2 & & & 7.9 \\
\hline 25 & & 21.2 & 1.10 & 11.0 & 21.7 & 0.70 & 11.6 & 18.5 & 0.93 & 9.9 \\
\hline
\end{tabular}


READY REFERENCE TABLES-CONTINUED.

\begin{tabular}{|c|c|c|c|c|c|c|c|c|c|}
\hline $\begin{array}{l}\text { Pounds of } \\
\text { fodder }\end{array}$ & 吾岂 & $\begin{array}{l}\Xi \\
0 \\
0 \\
0 \\
0\end{array}$ & ن & 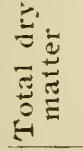 & ב⿱艹 & 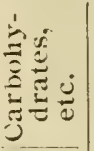 & E气 & $\frac{\Xi}{0}$ & 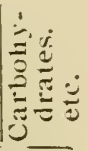 \\
\hline Hays & \multicolumn{3}{|c|}{ Oat hay, 1:9.9 } & \multicolumn{3}{|c|}{ 0at and pea hay, $1: 4.1$} & \multicolumn{3}{|c|}{ Hungarian, $1: \overline{0.0}$} \\
\hline $21 / 2$ & 2.3 & 0.19 & 10 & 2.2 & 0.28 & 1.2 & 2.1 & 0.12 & 1.2 \\
\hline & 4.6 & 0.21 & 2.0 & 4.4 & 0.56 & 2.3 & 4.2 & & 24 \\
\hline $1 / 2$ & 6.8 & 0.31 & 3.0 & 6.6 & 0.84 & 3.5 & 6.3 & 0.37 & 3.6 \\
\hline 10 & 9.1 & 0.41 & $4 .()$ & 8.9 & 1.12 & 4.6 & 8.4 & 49 & 4.9 \\
\hline $21 / 2$. & 11.4 & .51 & 5.1 & 11.1 & 1.40 & 5.8 & 10.4 & 0.62 & 6.2 \\
\hline 5 & 13.7 & .62 & 6.1 & & 1.68 & 6.9 & 2.5 & .74 & 7.4 \\
\hline $7 \mathrm{x} / 2$ & 16.0 & 72 & 7.1 & .5 & 1.96 & 8.1 & & & 8.6 \\
\hline & 18.2 & 82 & 8.1 & 7.7 & 2.24 & 9.2 & 16.7 & 0.98 & 9.8 \\
\hline . . & 2.8 & 1.03 & 10. & 22.1 & 2.80 & 11.6 & & 12.3 & 12.3 \\
\hline Hays etc. & \multicolumn{3}{|c|}{ Red clnver hay, $1: 5.0$} & \multicolumn{3}{|c|}{ Alsike clover hay, $1: 5.5$} & \multicolumn{3}{|c|}{ Oat straw, $1: 383$} \\
\hline $1 / 2 \ldots \ldots$ & 2.1 & 0.18 & 1.0 & 2.3 & 0.21 & 1.2 & 2.3 & 0.03 & 1.2 \\
\hline & 4.2 & & 2.1 & & & 2.3 & & & 2.3 \\
\hline $1 / 2$ & 6.4 & 0.53 & 3.2 & 6.8 & 0.63 & 3.5 & 6.8 & .09 & 3.5 \\
\hline & 8.5 & 71 & 4.2 & 9.0 & & 4.6 & 9.1 & & 4.6 \\
\hline $21 / 2$ & 10.6 & & 5.2 & 1.3 & 1.0 & 5.8 & & & 5.8 \\
\hline & & & & & 1.26 & 6.9 & & & 6.9 \\
\hline $71 / 2$ & .8 & & 7.3 & & & 8.1 & & & 8.1 \\
\hline & 16.9 & 1.42 & 8.3 & & 1.68 & 9.2 & 8.2 & 0.24 & 9.2 \\
\hline & 21.2 & 1.78 & 10.5 & 22.6 & 2.10 & 11.6 & & 0.30 & 11.5 \\
\hline Dry fo & \multicolumn{3}{|c|}{ Corn fodder, $1: 14.3$} & \multicolumn{3}{|c|}{ Corn stover, $1: 236$} & \multicolumn{3}{|c|}{ Wheat straw, $1: 95.0$} \\
\hline $1 / 2$ & 1.4 & & 0.9 & 1.5 & 0.04 & 08 & 2.3 & 001 & 11.9 \\
\hline & & & & & & & & & \\
\hline $1 / 2$ & 4.3 & & 2.7 & & & 2. & 6.8 & & 2.8 \\
\hline & 5.8 & & 3.6 & & & 3.3 & 9.0 & & 3.7 \\
\hline $21 / 4 \cdot$ & 7.2 & & 4.5 & 7. & & 4.1 & & & 4.6 \\
\hline & 8.7 & & 5.4 & & & 5.0 & & & 5.6 \\
\hline $71 /$ & 10.1 & .44 & 6 & & & 8 & & & 6.5 \\
\hline & & & 7.1 & & & 6.6 & & & $7 \cdot 4$ \\
\hline & 14.5 & 0.63 & 8.9 & 15.0 & 0.35 & 8.3 & 22.6 & 0.10 & 9.3 \\
\hline & \multicolumn{3}{|c|}{ Corn meal, $1: 11.3$} & \multicolumn{3}{|c|}{ Corn \& cob meal, 1:13.9 } & \multicolumn{3}{|c|}{ 0ats, $1: 0.2$} \\
\hline & & & & & & 0.2 & 0.2 & 0.02 & 0.1 \\
\hline 7 & & & 0.4 & & & & 0. & & 0.3 \\
\hline 1 & 0.9 & & 0.7 & 0.9 & 0. & 0.7 & 0.9 & & 0.6 \\
\hline 2 & 1.7 & & 1.4 & 1.7 & & & 1.8 & & 1.1 \\
\hline 3 & 2.6 & & 2.1 & 2. & & 2.0 & 2. & & 1.7 \\
\hline 4 & 3. & & 2.9 & 3. & & 2.7 & 3. & & 2.3 \\
\hline 5 & & & 3.6 & 4.3 & 0. & 3.4 & 4.5 & 0.46 & 2.8 \\
\hline & 6.4 & & 5.4 & & & 5.1 & 6.7 & 0.69 & 4.3 \\
\hline & 85 & 0.63 & 7.1 & 8.5 & 0.48 & 6.7 & 8.9 & 0.92 & 5.7 \\
\hline
\end{tabular}


I 88

READY REFERENCE TABLES-CONTINUED.

\begin{tabular}{|c|c|c|c|c|c|c|c|c|c|}
\hline Pound & 氞 & : & 它点 & 奇 & $\begin{array}{l}\frac{a}{0} \\
\frac{3}{3} \\
a_{1}\end{array}$ & ن & 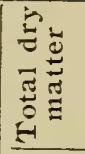 & ב. & ن \\
\hline By products & \multicolumn{3}{|c|}{ Barleg, $1: 8.0$} & \multicolumn{3}{|c|}{ Barley screenings,1:7.7 } & \multicolumn{3}{|c|}{ Wheat bran, 1:3.8 } \\
\hline & 0.2 & 0.02 & 0.2 & 0.2 & 0.02 & 0.2 & 0.2 & 0.03 & 0.1 \\
\hline & & 0.04 & 0.3 & 0.4 & 0.04 & 0.3 & 0.4 & & 0.2 \\
\hline 1 & 0.9 & 0.0 & 0.7 & 0.9 & 0.0 & 0.7 & 0.9 & & 0.5 \\
\hline 2 & 1. & 7 & 1. & 1.8 & 0 . & 1. & 1.8 & & 1.0 \\
\hline & 7 & 0.2 & 2.1 & 2.6 & 0. & 2.0 & 2. & & 1.4 \\
\hline$\ldots \ldots$ & & & 2.8 & 3.5 & & 2.7 & 3. & & 1.8 \\
\hline & & & 3. & 4.4 & & 3. & 4 & & 2.3 \\
\hline $71 / 2 \ldots$ & 6.7 & & 5. & 6.6 & & 5.0 & 6.6 & 0.90 & 3.4 \\
\hline 10 & & 0 & 6.9 & 8.8 & 0.86 & 6.6 & 8 & & 4.6 \\
\hline By products & \multicolumn{3}{|c|}{ Wheat middlings.1:4.6 } & \multicolumn{3}{|c|}{ Wheat screenings, 1:5.2 } & \multicolumn{3}{|c|}{ Bed-dog flous, $1: 3.3$} \\
\hline $1 / 4 \ldots$ & 0.2 & 0.03 & 0.1 & 0.2 & 0.02 & $0 . \overline{0.1}$ & 0.2 & 0.04 & 0.1 \\
\hline & & & 0 . & 0. & & 0.2 & & 9 & 0.3 \\
\hline 1 & & 0.1 & 0.6 & 0.9 & 0.10 & 0.5 & 0.9 & 0.18 & 0.6 \\
\hline & 1.8 & & 1.2 & 1.8 & & 1.0 & & & 1.2 \\
\hline & & 0.2 & 1.7 & 2.7 & 0 . & 1.5 & 2.7 & & 1.7 \\
\hline & .5 & & 2.3 & 3.5 & & 2.0 & 3.6 & & 2.3 \\
\hline & & & 2.9 & 4.4 & & 2.5 & & & 2.9 \\
\hline $71 / 2 \ldots$ & & 0.94 & 4.4 & 6.6 & 0. & 3.8 & 6.8 & 1.34 & 4.4 \\
\hline 10 & & 1.25 & 5.8 & 8.8 & 0.98 & 5.1 & 9.1 & 1.78 & 5.8 \\
\hline By products & \multicolumn{3}{|c|}{ Rpe 1:7.8 } & \multicolumn{3}{|c|}{ Rye bran, 1:5.1 } & \multicolumn{3}{|c|}{ Cottcrseed meal, $1: 1.0$} \\
\hline $1 / 4$. & & 0.62 & 02 & 0.2 & 0.03 & 0.2 & 0.2 & & 0.1 \\
\hline & & & 0.3 & & & & & & 2 \\
\hline & 0.9 & & 0.7 & 0.9 & & 0.6 & & & 0.4 \\
\hline & 1.8 & & 1.4 & 1.8 & 0. & 1.3 & & & 0.8 \\
\hline & & & 2.1 & 2.7 & & 1.9 & & & 1.2 \\
\hline & 3.5 & & 2.8 & & & 2. & 7 & & 1.6 \\
\hline & & & 3.5 & & & 3. & 4. & & 2.0 \\
\hline & & & 5.2 & & & & 6 & & 3.0 \\
\hline & 8.8 & (1).89 & 6.9 & 8.8 & 1.23 & 6.3 & 9.2 & 4.00 & 4.0 \\
\hline By products & \multicolumn{3}{|c|}{ Cottonseed hulls, - } & \multicolumn{3}{|c|}{ Linseed meal 0.p. 1:1.5 } & \multicolumn{3}{|c|}{ Linseed meal, a p. $1: 1.3$} \\
\hline & 0.2 & & 0.1 & 0.2 & 0.08 & 0.1 & 0.2 & & 0.1 \\
\hline & & & 0. & & & 0 . & & & 0.2 \\
\hline & & & & & & 0 . & 0 . & & 0.4 \\
\hline & & & 0 . & 1. & & 1. & 1. & & 0.8 \\
\hline & 2.7 & & 1.1 & 2.7 & 0. & 1.2 & 2.7 & & 1.3 \\
\hline & 3. & & 1.5 & & & 1. & & & 1.7 \\
\hline & 4.5 & & 1.8 & 4.9 & 1. & 2.3 & 4.5 & & 2.1 \\
\hline $7 \mathrm{~s} / 2$. & 6.7 & & 2.7 & 6. & & 3.4 & 6.7 & & 3.2 \\
\hline$\ldots$ & 8.9 & & 3.7 & 9.0 & 3.08 & 4.6 & 8.9 & 3.24 & 4.2 \\
\hline
\end{tabular}


READY REFERENCE TABLES - CONTINUED.

\begin{tabular}{|c|c|c|c|c|c|c|c|c|c|}
\hline $\begin{array}{l}\text { Pounds of } \\
\text { feed }\end{array}$ & 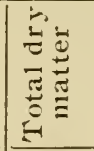 & 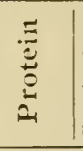 & 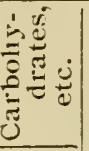 & 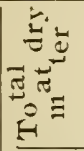 & 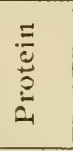 & 实 & 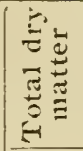 & $\frac{3}{3}$ & 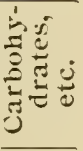 \\
\hline By Products & \multicolumn{3}{|c|}{ Flax meal, 1:1,4 } & \multicolumn{3}{|c|}{ Gluten meal(Cli. ) 1:1.5 } & \multicolumn{3}{|c|}{ Gluten meal, Cream, 1:1.7 } \\
\hline & 0.2 & 0.08 & O. I & 0.2 & 0.08 & O. I & 0.2 & 0.07 & O. I \\
\hline & 0.4 & 0.16 & 0.2 & 0.4 & o. I6 & 0.2 & 0.4 & O. I 5 & 0.2 \\
\hline I & 0.9 & 0.32 & 0.4 & 0.9 & 0.32 & 0.5 & 0.9 & o. & 0.5 \\
\hline 2 & I. 9 & 0.64 & 0.9 & I. $S$ & 0.64 & 0.9 & I. 8 & 0.59 & I.O \\
\hline 3 & 2.7 & 0.96 & I. 3 & 2.6 & 0.96 & I. 4 & 2.7 & 0.89 & I. 5 \\
\hline & 3.6 & 1.28 & I. 7 & $3 \cdot 5$ & I. $2 \mathrm{~S}$ & I. 9 & 3.6 & I. I9 & 2. I \\
\hline & $4 \cdot 5$ & $\mathrm{~J} .6 \mathrm{O}$ & 2.2 & 4. & 1.60 & 2.3 & 4 & & 2.6 \\
\hline $71 / 2$. & 6.7 & 2.40 & $3 \cdot 3$ & 6.6 & 2.40 & $3 \cdot 5$ & 6.7 & 2.23 & $3 \cdot 9$ \\
\hline IO $\ldots$ & 8.9 & $3 \cdot 2 \mathrm{I}$ & $4 \cdot 3$ & 8.8 & $3.2 \mathrm{I}$ & 4.7 & 9.0 & .97 & 5.1 \\
\hline Ey Products & \multicolumn{3}{|c|}{ Gluten feerl, Buffialo. 1:2.4 } & \multicolumn{3}{|c|}{ Hominy ehop, 1:9.2 } & \multicolumn{3}{|c|}{ Dried lorewers grain 1:9.0 } \\
\hline $1 / 4 \ldots$ & 0.2 & 0.06 & O. I & 0.2 & 0.02 & 0.2 & 0.2 & 0.04 & O.I \\
\hline & 0.4 & 0.12 & 0.3 & 0.5 & 0.04 & 0.4 & 0.5 & 0.08 & 0.3 \\
\hline & 0.9 & 0.23 & 0.6 & 0.9 & 0.09 & 0.8 & 0.9 & . I6 & 0.5 \\
\hline & I.S & 47 & 1. I & I. 8 & 0.1 & I. 6 & I. 8 & & 0.9 \\
\hline & 7 & 70 & I. 7 & 2.8 & 0.26 & 2.4 & S & & I. 4 \\
\hline & 3.6 & 0.93 & 2.3 & 3.7 & 0.35 & 3.2 & $3 \cdot 7$ & .63 & 1.9 \\
\hline & $4 \cdot 5$ & I. I 7 & 2.8 & 4.6 & 0.44 & 4. & & 79 & 2.4 \\
\hline $71 / 2$ & 6.8 & I. 74 & $4 \cdot 3$ & 6.9 & 0.65 & 6.0 & & I. IS & $3 \cdot 5$ \\
\hline 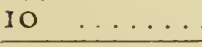 & 9.0 & 2.33 & 5.9 & 9.2 & 0.87 & S.O & 9.2 & I. 57 & 4.7 \\
\hline By Products & \multicolumn{3}{|c|}{ Atlas gluten unal, 1:2.6 } & \multicolumn{3}{|c|}{ Malt sprouts, J:2.2 } & \multicolumn{3}{|c|}{ Pea meal, 1::.2 } \\
\hline & 0.2 & 0.06 & 0.2 & 0.2 & 0.05 & 0.1 & 0.2 & .04 & O. I \\
\hline & 0.5 & O. 12 & 0.3 & 0.4 & 0.09 & 0.2 & 0.4 & 0.08 & 0.3 \\
\hline I & 0.9 & 0.25 & 0.6 & 0.9 & 0.19 & 0.4 & 0.9 & O. I7 & 0.5 \\
\hline 2 & 1.8 & 0.49 & I. 3 & 1.5 & 0.37 & $0 . S$ & I. 8 & & I. I \\
\hline 3 & 2.8 & 0.74 & 1.9 & 2.7 & 0.56 & I. 2 & 2.7 & 0.50 & I. 6 \\
\hline & 3.7 & 0.98 & 2.6 & 3.6 & 0.74 & 1.6 & 3.6 & 0.67 & 2. I \\
\hline & 4.6 & I. 23 & 3.2 & $4 \cdot 5$ & 0.93 & 2.0 & 4.5 & 0.84 & 2.7 \\
\hline $7 \mathrm{r} / 2 \ldots \ldots$ & 6.9 & I. 85 & $4 \cdot 9$ & 6.7 & I. 40 & 3.0 & 6.7 & & 4.0 \\
\hline IO $\ldots \ldots \ldots$ & 9.2 & 2.46 & 6.5 & 9.0 & I. 86 & 4.0 & 9.0 & I.68 & $5 \cdot 3$ \\
\hline
\end{tabular}




\section{CONCLUSION.}

In conclusion we desire to state that the object of this book is to place before the farmer and dairyman such information as will be valuable and practical, in as concise and plain a manner as possible, and to make a plea in behalf of the silo as an improver of the financial condition of the farmer. That the silo is a prime factor in modern agriculture is no longer a matter of doubt. The silo is not the sum total in itself, but as an adjunct, and, in the case of dairying, a necessary adjunct to successful and profitable methods, its value is difficult to overestimate.

One of the greatest values of the silo is that as an innoration it becomes a stepping-stone to better methods in general; it stimulates its owner and spurs him on to see just how good and far reaching results he can obtain from his revised system of management. It invites a little honest effort, and coupled with this it never fails. It enables its owner not only to do what he has been unable to do before, but things he has done without its help the silo enables him to do at less cost than before. The solution of the problem of cost of manufacture is necessary to every successful producer, and as the proposition is constantly changing, the solutions of our forefathers, or even of a generation ago, no longer avail. The silo is not an enticing speculation by means of which something can be gotten out of nothing, but a sound business proposition, and has come to stay. The voices of thousands of our best farmers and dairymen sing its praises, because it has brought dollars into their pockets, and increased enjoyment to them in their occupations and their homes. 
Have you cows? Do you feed stock? Do you not need a silo? Is it not worthy of your best thought and consideration? You owe it to yourself to make the most you can out of the opportunities before you. Do IT Now! 


\section{GLOSSARY .}

Ad libitum. At pleasure; in case of feeding farm animals, all they will eat of a particular feeding stuff.

Albuminoids. A group of substances of the highest importance in feeding farm animals, as they furnish the material from which flesh, blood, skin, wool, casein of milk, and other animal products are manufactured. Another name for albuminoids is fleshforming substances or protein.

Ash. The portion of a feeding stuff which remains when it is burned, the incombustible part of foods. The ash of feeding stuffs goes to make the skeleton of young animals, and in case of milch cows a portion thereof goes into the milk as milk ash.

Bacteria. Microscopic vegetable organisms, usually in the form of a jointed rod-like filament, and found in putrefying organic infusions. They are widely diffused in nature, and multiply with marvelous rapidity. Certain species are active agents in fermentation, while others appear to be the cause of certain infectious diseases.

Balanced ration. A combination of feeding stuffs containing the various nutrients in such proportions and amounts as will nurture the animals for twentyfour hours. with the least waste of nutrients.

By-Products. A secondary product of an industry ; cottonseed meal is a by-product of the cotton oil industry; skim milk and butter milk are by-products of butter making.

Carbhydrates. A group of nutrients rich in carbon and containing oxygen and hydrogen in the proportion in which they form water. The most important carbhydrates found in feeding stuffs are starch, gums and crude fiber (celulose.) 
Carbon. A chemical element, which with the elements of water makes up the larger part of the dry matter of plants and animals.

Carbonic acid. A poisonous gas arising from the combustion of coal or wood It is formed in all kinds of fermentations and therefore occurs in the siloing of fodders.

Cellulose. See Crude fiber.

Crude fiber. The frame work forming the walls of cells of plants. It is composed of cellulose and lignin, the latter being the woody portion of plants and wholly indigestible.

Digestible matter. The portion of feeding stuffs which is digested by animals, i. e., brought into solution or semi solution by the digestive fluids, so that it may serve as nourishment for the animal and furnish material for the production of meat, milk, wool, eggs, etc.

Dry matter. The portion of a feeding stuff remaining after the water contained therein has been removed.

Ensilage. An obsolete word for Silage. Used as verb, likewise obsolete, for to silo; to ensile also sometimes incorrectly used for the process of placing green fodders into a silo.

Enzemes. An unorganized or chemical compound of vegetable or animal origin, that causes fermentation, as, pepsin, or rennet.

Ether extract. The portion of a feeding stuff dissolved by ether ; mainly fat or oil in case of concentrated feeding stuffs; in coarse fodders, fat mixed with a number of substances of uncertain feeding value, like wax, chlorophyll (the green coloring matter of plants), etc.

Fat. See Ether extract.

Feeding standard. A numerical expression of the amounts of the various digestible subtances in a combination of feeding stuffs best adapted to give good 
results as regards production of animal products, like beef, pork, milk, etc.

Indian corn. Zea Mays, the great American cereal and fodder-producing plant.

Hydrogen. A chemical element, a gas. Combined with oxygen it forms water, with oxgen and carbon it forms carbhydrates and fat; with oxygen, carbon and nitrogen (with small amounts of sulphur and phosphorus) it forms the complex organic nitrogenous substances known as protein albuminoid substances.

Legumes. Plants bearing seeds in pods and capable of fixing the gaseous nitrogen of the air, so that it becomes of value to the farmer and will supply nitrogenous food substances to farm animals. Examples, the different kinds of clover, peas, beans, vetches, etc. Of the highest importance agriculturally, as soil renovators, and in supplying farm-grown protein foods.

Nitrogen. A chemical element, making up fourfifths of the air. The central element of protein. See under Hydrogen.

Nitrogen-free extract. The portion of a feeding stuff remaining when water, fat. protein, crude fiber, and ash are deducted. It includes starch, sugar, pentosans, and other substances. It is so called because it does not contain any nitrogen.

Nitrogenous substances. Substances containing nitrogen (which see).

Nutrient. A food constituent or group of food constituents capable of nourishing animals.

Nutritiveratio. The proportion of digestible protein to the sum of digestible carbhydrates and fat in a ration, the per cent of fat being multiplied by $2 \frac{1}{4}$, and added to the per cent of carbhydrates (crude fiber plus nitrogen-free extract).

Organic matter. The portion of the dry matter which is destroyed on combustion (dry matter minus ash).

Oxygen. A chemical element found in a free state 
in the air, of which it makes up about one-fifth, and in combination with hydrogen in water; oxygen is also a rarely-lacking component of organic substances. See Carbhydrates and hydrogen.

Protein. A general name for complex organic compounds mainly made up from the elements carbon, hydrogen, oxygen and nitrogen. Crude protein includes all organic nitrogen compounds, while true protein or albuminoids (which see) only includes such nitrogenous substances in feeding stuffs as are capable of forming muscle and other tissues in the animal body.

Ration. The amount of food that an animal eats during twenty-four hours.

Roughage. The coarse portion of a ration, including such feeding stuffs as hay, silage, straw, corn fodder, roots, etc. Concentrated feeding stuffs are sometimes called grain-feeds or concentrates, in contradistinction to roughage.

Silage. The succulent feed taken out of a silo. Formerly called ensilage.

Silo. An air-tight structure used for the preservation of green, cuarse fodders in a succulent condition. As verb, to place green fodders in a silo.

Soiling. The system of feeding farm animals in a barn or enclosure with fresh grass or green fodders, as rye, corn, oats, Hungarian grass, etc.

Starch. One of the most common carbhydrates in feeding stuffs insoluble in water, but readily digested and changed into sugar in the process of digestion.

Succulent feeds. Feeding stuffs containing considerable water, like green fodders, silage, roots and pasture.

Summer silage. Silage intended to be fed out during the summer and early fall to help out short pastures.

Summer silo. A Silo used for the making of summer silage. 


\section{INDEX.}

Advantages of the silo

PAGE

Alfalfa silage......................... 114

Animal body, composition of the ............ 161

Analyses of feeding stuffs. .................. 179

Ash ...........................162, 164

Average composition of silage crops ........... 178

Beet-pulp silage . . . . .................. 117

Beets, cost of, per acre .................. 154

Beef cattle, silage for .... . . . . . . . . . . . . . . 144

Blower elevators ....................... 131

Brick silos . . . . . . . . . . . . . . . . . . . . . 8 8

Capacity of round silos... . . ............ 31

Carbonic-acid poisoring in silos, danger from ...... 133

Certified milk, silage in production of ... . . . . . 141

Chemical composition of silage. . . . . . . . . . . 178

Chute for a round wooden silo... . . . . . . . . . . 82

Circles, circumferences and areas of........... 81

Clover silage ......................111, 136

Clover silage, cost of ... . . ............. 112

Clover, time of cutting for the silo ............. 113

Clover, yield per acre of ................... 113

Corn, cutting of, in the field ................. 120

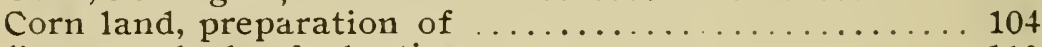

Corn, methods of planting ................... 110

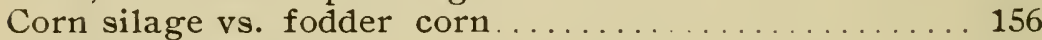

Corn silage vs. hay ....... . . . . . . . . . . 155

Corn silage vs. roots $\ldots \ldots \ldots \ldots \ldots \ldots \ldots$

Corn, siloing of, "ears and all", .......... 123

Corn, see also Indian corn and Fodder corn.

Corners of square silos methods of excluding air from. 90

Cost of beets per acre ... . . . . . ...... 154

Cost of a pound of digestible dry matter in different feeding stuffs . . ... . . . . . . . 184

Conclusion ....................... 190

Cost of corn silage $\quad \ldots \ldots \ldots \ldots \ldots \ldots \ldots 12,154$

Cost of silos ............. ...... . 95

Covering silage .... $\ldots \ldots \ldots \ldots \ldots \ldots \ldots$

Cow-pea silage ....................... 114

Comparative losses in dry curing $\ldots \ldots \ldots \ldots \ldots . \ldots \ldots$

Corn time of cutting for silo $\ldots \ldots \ldots \ldots \ldots \ldots \ldots \ldots \ldots$

Composition of the animal body .................... 161

Composition of the silage crops............. 178

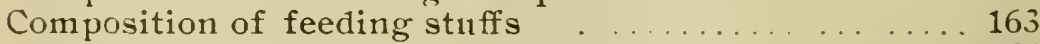

Crude fiber.... $\ldots \ldots \ldots \ldots \ldots \ldots \ldots \ldots \ldots$

Cutter and power, size of . . . . . . . . . . . . 127

Definitions of terms used ................. 192 
Description of round wooden silos

Description of "Ohio" silage cutters

Doors for silos...... . . . . . . . . . . . . $\quad 46,73$

Ears and all, siloing of corn................ 123

Economy of storage ...... .............. 21

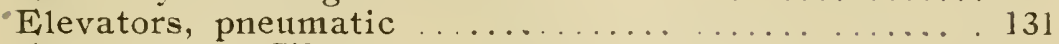

Finsilage, see Silage.

Estimating of materials for silos ............. 98

Feeders's guide, etc... . . . . . . . . . . . . . 161

Feeding stuffs, composition of .............. 163

Feeding standards . . . . . . . . . . . . . . 168, 170, 171

Feeding of silage $\ldots \ldots \ldots \ldots \ldots \ldots \ldots . \ldots \ldots$

Field-curing of fodder corn, losses in . . . . . . . 13, 16

Filling of silo . . . . . . . . . . . . . . . . 22, 120, 125

Freezing of silage. $\quad \ldots \ldots \ldots \ldots \ldots \ldots$

General requirements for silos . . . . . . . . . . 26

Grain mixtures for dairy cows .............. 175

Guide, a feeders' ...................... 161

Hauling corn from field, rack or sled for. . . . . . . 122

Hills or drills, planting of corn in ........... 110

History of the silo .. . . . . . . . . . . . 9

Horizontal girts, silos with . . . . . . . . . . . . . 91

Horses, silage for ....................... 145

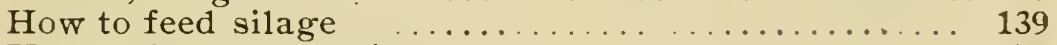

How to figure out rations $\ldots \ldots \ldots \ldots \ldots$

Indian corn, soil adapted for................. 104

Indian corn, methods of planting $\quad \ldots \quad \ldots . . . \ldots 110$

Indian corn ...

Indian corn, chemical changes in ............ 108

Indian corn, increase in food ingredients from tasseling to ripeness ... ........ 109

Indian corn, varieties of, to be planted for the silo .... 105

Indian corn, see also Corn and Fodder Corn.

Introduction. . . . . . . . ... ................ 9

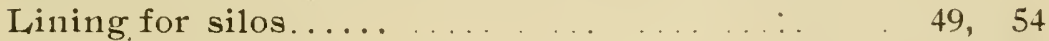

Losses in dry curing $\quad \ldots \ldots \ldots \ldots \ldots$

Losses in the siloing process.............. . 17

Losses in siloing Alfalfa $\ldots \ldots \ldots \ldots \ldots \ldots$

Low wagon for hauling corn $\quad \ldots \ldots \ldots \ldots \ldots \ldots 122$

Lucern, See Alfalfa.

Materials for the silo. ... . . . . . . . . . . . . 69

Metal bucket chain elevators _.............. 128

Milch cows, silage rations for .. . . . . . . . . . 142

Milch cows, silage for ... . . . . . . . . . 139

Mineral Matter ... . . . $\quad \ldots \ldots \ldots \ldots \ldots$. . . 62,164

Modifications of "Wisconsin" silo ............. 55 
New Jersey Experient Station silo. . . . . . . . . . . 130

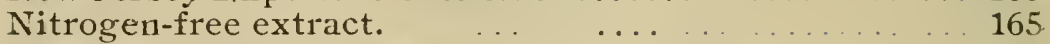

Number of staves required for stave silos $\ldots \ldots \ldots . . .81$

Nutritive Ratio . . ... . ... . . . . . . . . 169.

Octagonal silos............................................ 91

"Ohio" silage cutters, description of................. 128, 131.

Painting the silo lining.................................... 54

Plastered round wooden silos.................................... 56

Planting corn, in hills or in drills.......................... 110

Planting corn, methods of .................................. 110

Planting corm, thickness of ................................. 110

Pneumatic elevators........................................ 131

"Poultrymen's silos".......................................... 15j

Poultry, silage for........................................ 152

Preparation of corn land..................................... $110^{\circ}$

Preservation of silos....................................... 101

Protein..................................................162, 164

Rations, how to figure out............................... 172

Rack, low-down, for hauling corn........................ 122

Rations, silage, for dairy cows............................ 142

Relative value of feeding stuffs............................ 167

Ready reference tables...................................... 185

Roof for the silo.............................. 51, 67, 75, 76

Round silos............................................... 38

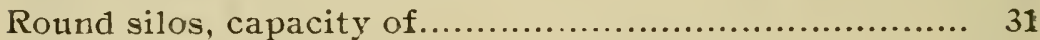

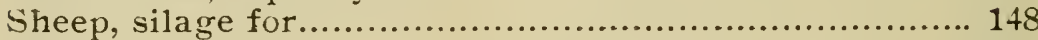

Silage, a]falfa............................................. 114

Silage cart................................................... 139

Silage, chemical composition of.......................... 178

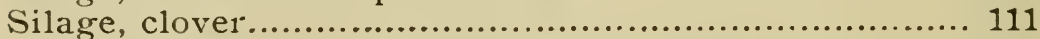

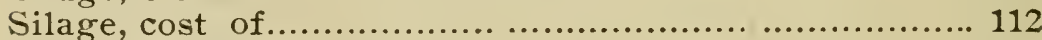

Silage crops................................................ 104

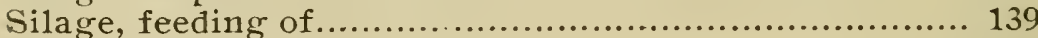

Silage for horses.......................................... 145

Silage for milch cows.................................139, 142

Silage for poultry ........................................... 152

Silage for sheep................................................ 148

Silage for beef cattle............................................ 144

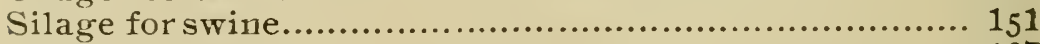

Silage, freezing of ........................................ 137

Silage, quantities of, required for different herds........ 32

Silage rations for milch cows............................ 142

Silage, how to feed.......................................... 139

Silos, acreage to fill......................................... 32

Silos, how to build............................................. 26

Silos, general requirements for............................... 26

Silos, on the form of..................................... 37 


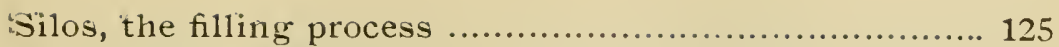

Silos, time of filling...................................... 22, 120

Silos, roof for................. ............................. 51

Silos, round all-stone................................... 82, 86

Silos, round wooden ........................................ 38

Silos, round wooden, capacity of ............................. 31

Silos, chute for.......................................... 82

Silos, cost of........................................ 54, 55, 58, 76, 90, 95

Silos, location of ....................................................... 36

Silos, specifications for............................. 38, 55, 56, 64. 92

Silos, square, methods of excluding air from corners of 90

Silos, stone.................................................... 86

Silos, value in intensive farming................................ 24

Silos, ventilation of............................................................ 52

Silos with horizontal girts................................................. 91

Silos, foundation of $\ldots \ldots \ldots \ldots 38,39,41,43,64,92$

Size of silo required........................................................ 29

Silos, brick lined ..... . ............. 60

Silos, all brick .......... . . . . . . . 85

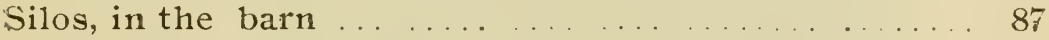

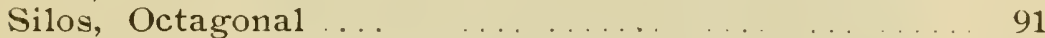

Size of cutter and power requirea $\quad \ldots \ldots \ldots \ldots \ldots 127$

Sorghum silage $\quad \ldots . . . \quad \ldots \ldots \ldots 11 \%$

Southern and Northern varieties of corn, comparative yields of ... . . . ....... 106

Soiling crops, table of .. ....... 183

Soiling crops, time of planting and feeding .... . . 183

Soja Beans _..... ... . . 116

Specifications for a round wooden silo, "Wisconsin". .. 38

Specifications for a stave silo _ _ . . . . . . 64

Stave silos $\ldots 60,77,79$

Stave silos, calculation of staves required for ... 81

Sitave silos, roof of .. . . . . . . 67 67

Stave silos, specifications for _. . . . . 64

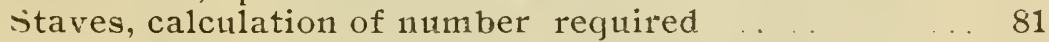

Steers, silage for . . . . . . . . . . . . . . . . . . . . 144

Stone silos $\quad \ldots \ldots \ldots \ldots \ldots \ldots$

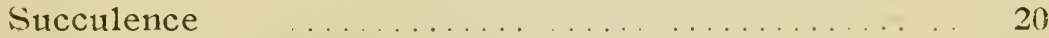

Swine, silage for . . . . . . . . . . . . . 151

Thickness of planting corn ............. 110

Time of filling the silo $\quad \ldots \ldots \ldots \ldots \ldots \ldots 22,120$

Time of cutting corn for the silo ... . . . . . . . 107

Varieties of corn to be planted for the silo ... . . . 105

Water, use of in filling silos ............... 135

Weight of concentrated feeds . . . . . . . . 182

Wisconsin Experiment Station silos, descriptions of 59, 60

Yields of clover per acre ... .............. 113 


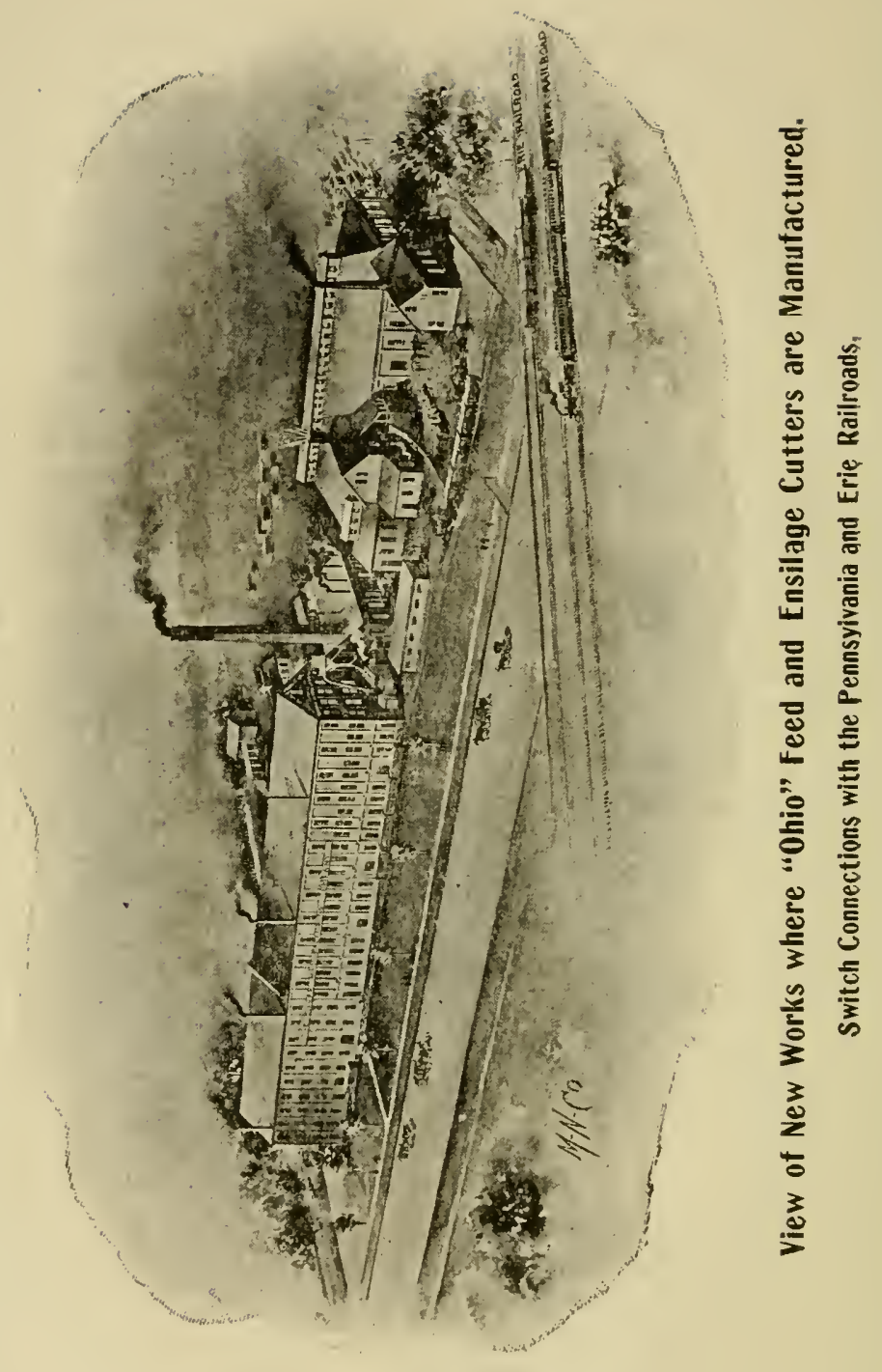




\section{"Ohio" Standard Feed and Ensilage Cutter}

Showing New Metal Bucket Carrier, Set for Right-Angle Delivery.

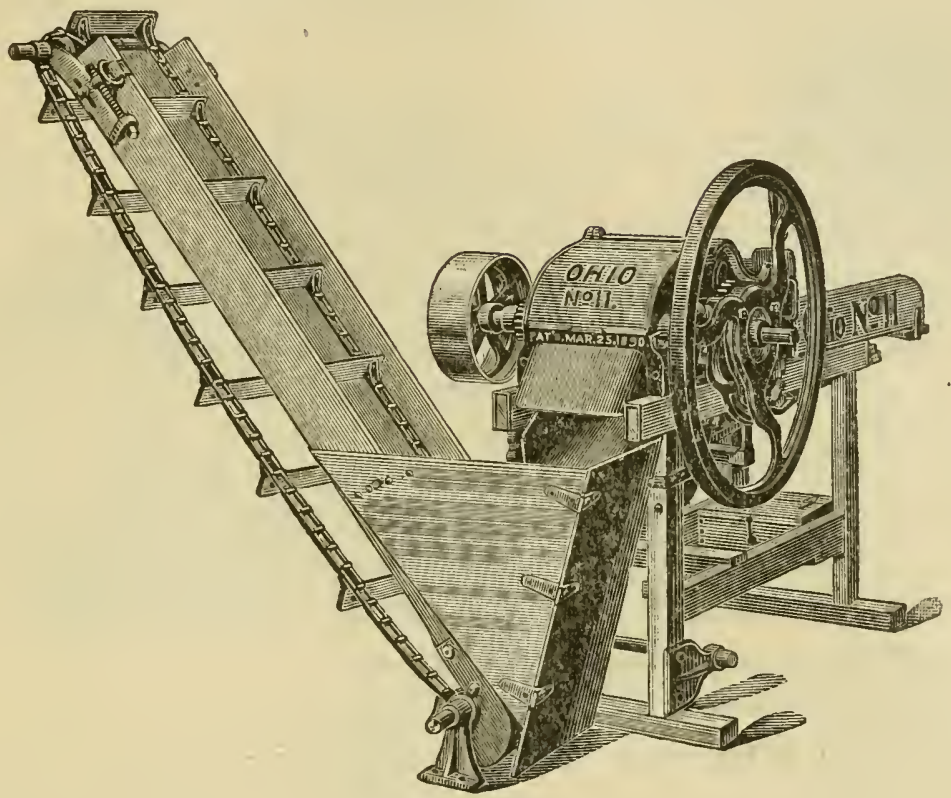

Fig. 784, No. 11.

SIZES AND PRICES.

No. 11 With two knives, 11 inches long, 4 lengths cut $\$ 40.00$ No. 11 With four knives, 11 inches long, 4 lengths cut. . 45.00 Extira gears to cut 4 inches long Reversible carrier, angle or straight delivery,

12 feet long or less.

Straight-delivery carrier, without reversible attachments. ............... 30.25 Additional length over 12 feet, extra per foot . . 1.70 Write for Discounts. 
Smallest Size Ensilage Cutter.

The illustration is a good representation of the smallest size ensilage cutter and it shows also the new metal bucket carrier set for right-angle delivery. This is the style carrier manufactured for this machine and it can be set at right or left angle, or straightaway.

Carrier Any Length.

Has best tool steel knives, readily adjusted to cutter bar. Strong, simple gearing; safety fly wheel, safety throw-out feed lever, four lengths of cut.

\section{Has Capacity to Fill 50-Ton Silos}

The cutter is substantial. has large capacity, and is adapted to cut all kinds of dry feed as well as ensilage. It has capacity to fill 50-ton silos, and even larger ones, but as this work necessitates a force of men and teams, and taking also into account the liability of frost, owners of silos usually give preference to a larger machine, so that the cutting may be done more quickly.

Ensilage Maintains More Cows, Produces More Milk.

Use of an Elevator.

The first and principal use of elevators of this kind is to convey cut ensilage into the silo. Other uses are to deliver dry cut feed, of whatever kind, into bays, bins, lofts and other places away from the machine, which saves the expense of a man.

Capacity, Speed, Power, Size of Pulley.

Dry feed, 2500 to 3000 pounds; ensilage, 3 to 4 tons per hour. Speed, 450 to 600 revolutions per minute. Power, 2 horge-power. Can also be run by one or two horse tread power. Pulleys, size sent, I $2 \times 4$-inch face; diameters 6,8 , Io and 5 inches can be furnished.

\section{Weight.}

No. I I Cutter, 420 pounds. Reversible carrier, I 2 feet long, 200 pounds. Extension, per foot, 8 pounds. 


\section{"Ohio" Standard Feed and Ensilage Cutter}

\section{And New Straightaway Metal Bucket Carrier}

Connected Up Ready for Use.

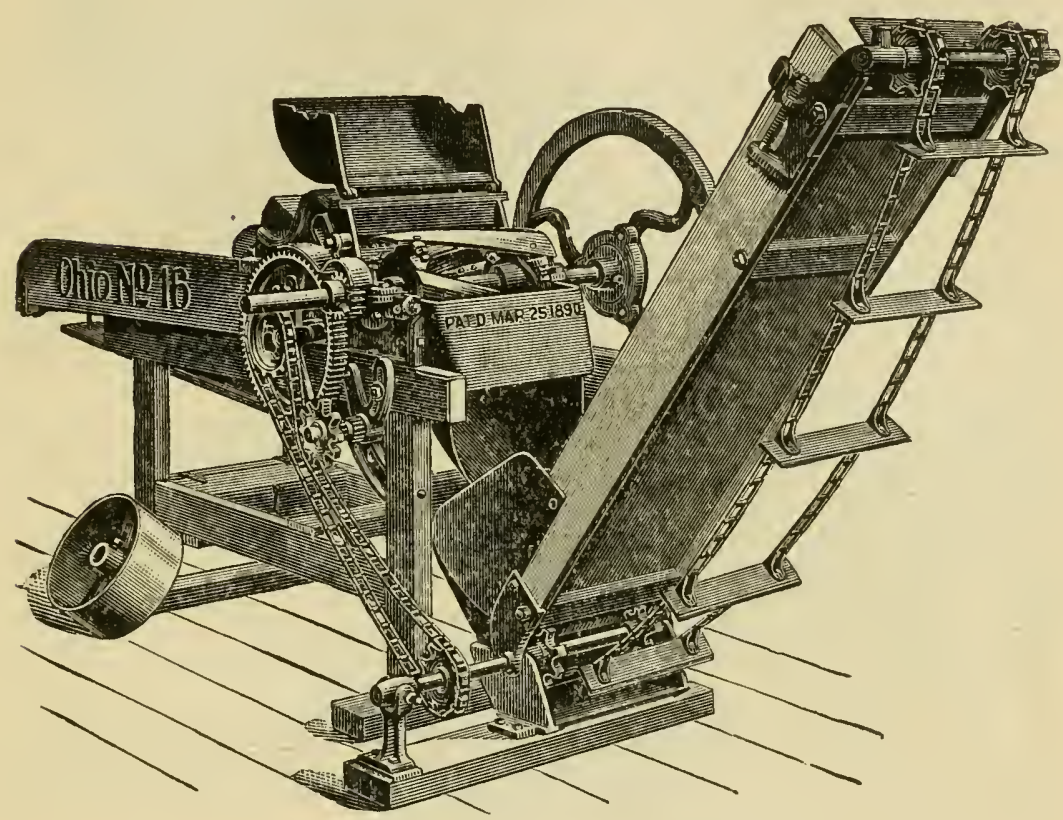

Fig. 784, Nos. 13, 16 and 18.

SIZES AND PRICES.

No. 13 With 2 knives, 13 inches long, 4 lengths of cut $\$ 60.00$ No. 13 With 4 knives, 13 inches long, 4 lengths of cut . 65.00 No. 16 With 4 knives, 16 inches long, 4 lengths of cut. 90.00

No. 18 With 4 knives, 18 inches long. 4 lengths of cut 120.00 Extra gears to cut 4 inches long, with 2 knives.. 4.00 Straight delivery carrier for either size, $12 \mathrm{ft}$. long 33.50 Swivel carrier for either size, $12 \mathrm{ft}$. long or under 45.00 Carrier, additional length over $12 \mathrm{ft}$. long, per foot 1.70 Wood cover, to fasten with hooks and eyes, per foot $\quad .25$ 


\section{Brief Comment on General Construction.}

The frame or stand is heary and substantial, which nakes it stiff and enduring. The feed box is wide and roomy, and reinforced at the top by a screw through the iron work and at the rear by angle irons. It alsu has an extension at the bottom to receive a platform, which is sometimes needed in feeding. The iron work is of sufficient weight to gire strength, and the bearings are heary and close up to machine. The shaft, knives and knife heads are of the best and erery part is properly put together. It has the 1900 extended front and hood, the safety tiy wheel, guards ofer gears, metal delivery chute, and erery point throughout of the latest and best.

\section{Feeding Device Clearly Ont1ined in Cut.}

The chain of feed gear pinious which operate the upper feed roller, the backwardly-inclined curred slot that the upper roller noves in, the adjustable feed lever and the springs underneath, are all nicely defined here. This chain of gears ribrate as the feed roller raises and lowers, yet their nuvable beariugs maintain their respective distances to each other and keep the gears properly in mesh without binding or friction, which gives a uniform motion to the roller. These features make the machine a sirong feeder. This feeding derice is made under U. S. pittents.

The feed lever is ad justable and its first use is to disconnect the chain of gears to change the length of cut. The length of cut is readily changed by either reversing the gear pinion on lower roller sliaft or substituting a different pinion. Another use ef this lever is to start and stop the feed. If the power runs down, or the nachine clogs for any reason whatever, or an accident occurs, the feed can be stopped instantly by grasping this lever. New Straight Metal Bucket Carrier.

The cut shows, first, the new straightaway metal bucket carrier and how to attach it to the machine; second, the front to the cutter and how it gires room for the cut feed to get away from the cylinder and how it will conduct the ensilage into the carrier.

The illustration is nade from a photograph of the "Ohio" Standard Cutter No. 16 and a new straightaway bucket carrier. This is the present style straight carrier and it is made for sizes Nos.13.16,18 and 19. It is applicable to cutters with extended tables and traveling feed aprons, as well as those like the illustration, and is recommended wherever a straight carrier can be used. It is easier to set up and move than the reversibie carrier.

Metal buckets upwards of two inches high are now used, ilsstead of low wood slats. and the sides of the carrier are more than one inch higher. This gives the carrier ample capacity to take away the, cnt feed an fast as it comes from the cutter, and 12 lessens the necessity for a cover, except when there is a high wind or very steep elevation.

\section{Carriers 50, 60 and 70 Feثt Long.}

At this tine the arerage lengths of carriers are $3+$ to +2 feet: they have bcen supplied as long as 50, 60 and 70 feet, and work perfectly, driven in the regular way from the botton.

\section{Adjustment Provided to Take Up Wear.}

There is adjustment provided at the top. tu take up wear in the chain or make any necessars adjustment. The oil cups in top irons are filled with waste, which holds the oil. Keep all bearings well viled with gond quality machine oil.

\section{Capacicy, Power Speed and Weight.}

Capacity, cutting ensilage, No. 13,4 to 6 tons: No. 16, 4 to 10 tons; No. 18,8 to 12 tois per hour. Power, No. 13, 2 to 4; No. 16, 2 to 8 : No. 18, 4 to 8 actual horse-power each. Speed, either size, 45.1 to 603 revolutions per minute. Size of pulleys furnisied with machines, $12 \times 6$-inch face. Diameters $6,8,10$ and 14 inches when wanted.

Cutters: No. 13, 560 pounds: No. 16,620 pounds: No. 18,700 pounds. Carrier: 12-foot straightaway complete, 240 pounds: 12-foot swivel conplete, 315 pounds. Extra length per foot, either style, 10 pounds.

The special features described under tle different machines are distinctive "Ohio" features, and are on all "Ohio" machines. The safety feed levers, patent adjustable gears, safety fly wlieel, full width throat, etc, are on all "Ohio" machines alike, and are some of the points that have made these machines so universally successful and satisfactory. 


\section{"Ohio" Selt-Feed Ensilage Cutter}

\section{And New Metal Bucket Swivel Carrier.}

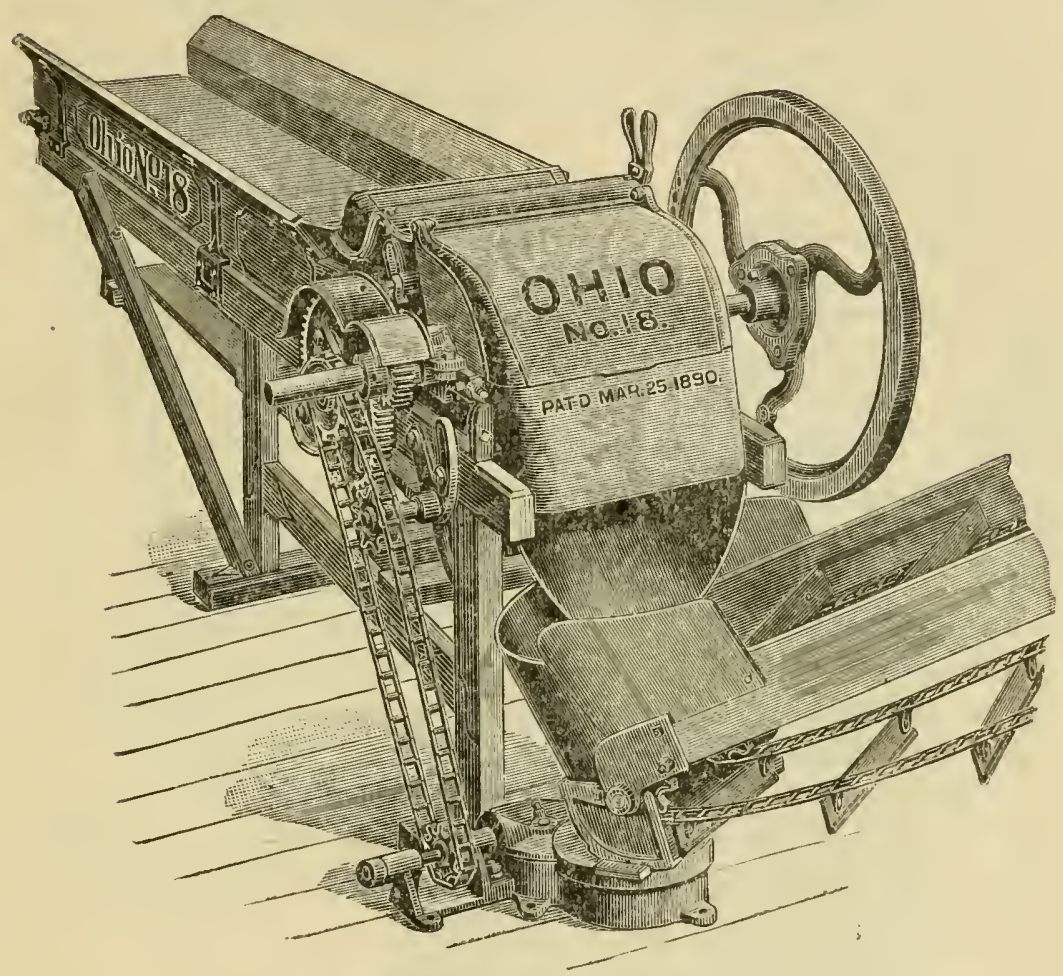

Fig. 785, Nos. 13, 16 and 18.

\section{SIZES AND PRICES.}

No. 13 With four 13 -inch knives, cuts $14,1 / 2,3 / 4$ and 1 inch.......\$ 95.00

No. 16 With four 16 -inch knives, cuts $1,4,1 / 2,3 / 4$ and 1 inch ........ 120.00

No. 18 With four 18 -inch knives, cuts $1,4,1 / 2,3 / 4$ and 1 inch ......... 155,00

Extra gears to cut four inches long, for Nos. 13, 16 or $18 \ldots \ldots 4.00$

Swivel carrier 12 feet long, for No. 13 Cutter............ 45.00

Swivel carrier 12 feet long, for No. 16 Cutter............ 45.00

Swivel carrier 12 feet long, for No. 18 Cutter............. 45.00

Extra length, per foot, for Nos. 13,16 or 18 Cutters......... 1.70

Wood cover, with hooks and eyes to fasten, for Nos, 13, 16 or

18 Cutters, per foot........................... .25

Write for Discounts. 


\section{The Illustration.}

It correctly represents the new "Ohio"s SeIf-Feed Ensilage Cutter and the present pattern metal bucket swivel carrier, and shows how the two are connected' up ready for use and how the carrier is driven from the cutter.

The traveling feed table, long enough to receive a bundle of corn is also shown, and is a valuable feature.

Self-feed means that it is only necessary to deliver the corn into the feed box. It goes through itself, which point alone saves the user one of the hard jobs on the farm. It increases capacity $33^{\mathrm{I} / 3}$ per cent. and more. It saves 75 per cent. of labor feeding and twomen constantly pushing to get the feed through the rolls are no longer needed. Custcmers frequently write: "We have to hustle to keep the machine supplied with corn." "Machine has done more than you recomnended," etc. The corn can be fed in armfuls or in bundles from the harvester, the feed box being ample for either.

The swivel carrier, also shown in the cut, enables the user to set the machine in any desired position. The base and wearing parts are self-contained, free from dirt and rigid and durable.

\section{Power, Capacity, Speed and Pulley.}

No. I 3 requires 4 to 6 horse-power and its capacity is 8 to 12 tons of ensilage corn per hour. No. I6 requires 6 to 8 horse-power and its capacity is 12 to 15 tons ensilage corn per hour. No. I 8 requires 6 to 10 horse-power and its capacity is 4 to 20 tons ensilage corn per hour. The pulley is $12 \times 6$-inch face, and sizes 6,8 , ro and i 5 inches diameter, when wanted. The proper speed is 450 to 600 revolutions per minute. 


\section{"Ohì" Monarch Self-Feed Ensilage Cutter And New Metal Bucket Swivel Carrier.}

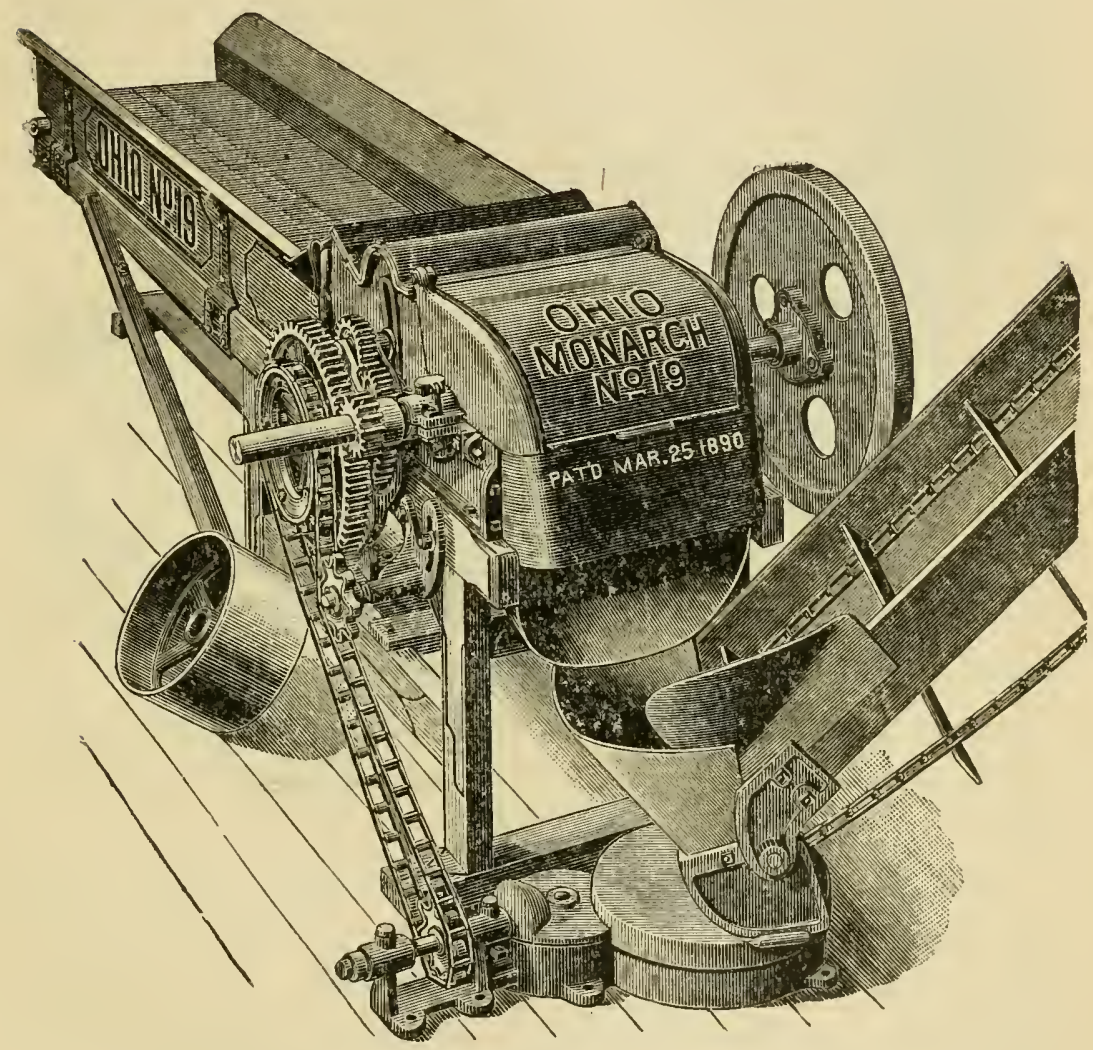

Fig. 794.

SIZE, AND PRICE.

No. 19 Cutter with four 19 -inch knives, cuts $1 / 2,3 / 4$ and 1 inch ....... $\$ 200.00$

Extra gears which cut 4 inches long with two knives......... 5.50

12 -foot straight carrier.......................... 40.00

12 -foot swivel carrier............................. 55.00

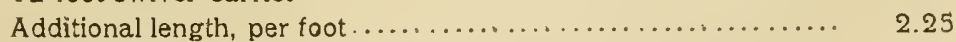

Wood cover, with hooks and eyes to fasten, per foot......... .35 
A new machine, heavy and porrerful, to meet the demand for a heavy unbreakable machine for larger users and transient work. It has heavy, strong frame and gears; self-feed, two safety levers; steel knife shaft $I 7 / 8$ inches in diameter; strong knife heads, four bolts in each knife: simple adjustment arrangement for knives; enormous capacity; great durabiiity, and is guaranteed in every retpect, as are all Ohio machines. It cannot fail to please.

\section{Capacity.}

I 7 to 25 tons of ensilage per hour.

Size of Pulley, Power, Speed and Weight.

The pulley is $14 \times 8$-inch face and is leather covered. Necessary power, 8 to 12 horse-power. Speed, 600 revolutions per minute. Weight of cutter, i 100 pounds; straight carrier I 2 feet long, 355 pounds; swivel carrier same length, 480 pounds. Extra length per foot, i 4 pounds.

"Ohio" Ensilage Cutters are also made with 20 and 24 inch knives, these sizes being heavy and proportioned correspondingly. They are not illustrated here, but are shown and described in the regular catalogue describing "Ohio" Ensilage Cutters.

"OHIO" STANDS FOR BEST. 


\section{"0hio" Self-Feed Ensilage Cutter}

\section{With Direct-Blast Blower Elevator.}

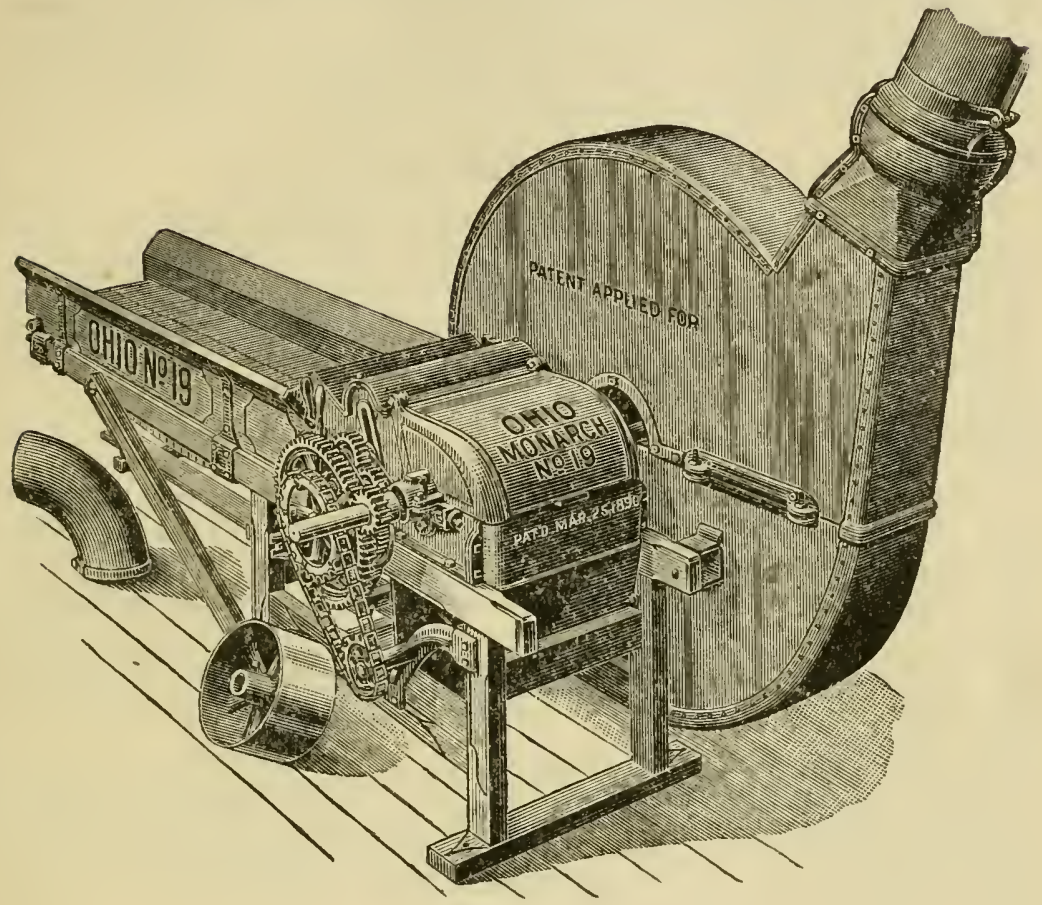

Fig. 793.

\section{SIZES AND PRICES.}

No. 13 Cutter, with four 13 -inch knives, cuts $1 / 2,3 / 4$ and 1 inch......\$ 95.00

No. 16 Cutter, with four 16-inch knives, cuts $1 / 2,3 / 4$ and 1 inch....... 120.00

No. 18 Cutter, with four 18 -inch knives, cuts $1 / 2,3 / 4$ and 1 inch....... 155.00

Extra gears which will cut 4 inches long with two knives..... 4.00

No. 19 Cutter, with four 19 -inch knives, cuts $1 / 2,3 / 4$ and 1 inch....... 200.00

Extra gears to cut 4 inches long with two knives............ 5.50

Blower comp ete with 2 -foot hood for top of pipe.......... 75.00

8-inch galvanized pipe in 4,6 and 10-foot lengths for No. 13,

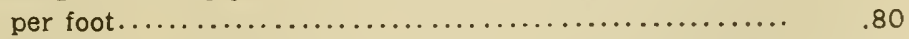

10-inch galvanized pipe in 4, 6, 8 and 10-foot lengths for No.

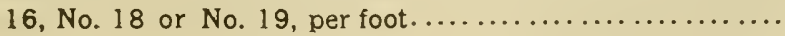

Liberal Discounts given. 


\section{A Successful Blower Elevator for the "Ohio" Cutters.}

The picture on the opposite page clearly outlines a new blower or wind elevator in connection with the "Ohio" SelfFeed Ensilage Cutter, and one that is adapted for use with the four sizes, Nos. 13, 16, 18 and 19 . The blower is wide and stands $51 / 2$ feet in diameter, which gives ample capacity to carry away and elevate the cut ensilage as fast as it comes from these large capacity cutters.

\section{The Blower Elevator and What It Will Do.}

The Blower Elevator is a new method for elevating cut silage into the silo. The one shown here will do this work perfectly, the only point being to maintain proper speed, and to set the pipe as nearly perpendicular as possibie. Running under these conditions, the blower will elevate the cut corn as fast as the machines cut it.

\section{How Constructed.}

The fan case being made of heavy sheet steel and painted with an iron-clad paint, insures strength and durability. The fan wings are made of 1/4-inch steel, riveted to heavy bar iron arms which are bolted to rim of solid center wheel, then the ends hooked and let into the wheel, making the fan absolutely safe. The fan wheel is mounted on the opposite end of pulley shaft, which makes the drive direct.

\section{Inlet in Fan Case.}

The inlet is just below the center, a little forward under the knife cylinder, where the exhaust catches the cut corn and by aid of the agitator draws it into the fan.

\section{The Pipe and Pipe Connection.}

The pipe is 10 inches in dianieter and made of heavy galvanized steel with seams on outside, and is very rigid. It is made in $4,6,8$ and 10 -foot lengths, with 10 -inch slip joints and a elamping band at each joint. The upper end of pipe is a curved elbow, which conducts the corn inio the silo. The pipe connection to fan case is a ball and-socket joint, which allows the pipe to oscillate to the right or left and straightaway.

\section{How the Pipe Must be Set.}

The pipe must be set as nearly perpendicular as possible. Experience has proven this to be the case. If lateral delivery is desired it should be accomplished by means of a long, easy elbow at the top, and not by giving a low slant to the entire length of pipe. 
"Ohio" Self-Feed Catter Well Known.

Upwards of one-half of the trade for ensilage cutters specifies the self-feed machine. They have been used successfully in every part of the country and hundreds of letters have been written commenting upon their merits. The new blower or wind elevator increases their efficiency in this point. The blower is made fast to the machine and the pipe can be erected and taken down in about one-tenth the time required to set up and move a chain elevator.

Self-Feed Saves Labor and Dollars.

Self-feed saves more labor and earns more dollars than any other point about an ensilage cutter. It saves three-fourths of the labor feeding ensilage and the cutting capacity is increased $33 \frac{1}{3}$ per cent.

\section{Capacity and Length of Pipe.}

No. 13,8 to 12 tons; No. 16, 12 to 15 tons; and No. 18,14 to 20 tons of ensilage per hour; No. 19, 17 to 25 tons of ensilage per hour. Feed the cutter regularly and keep speed up, and the blower will elevate the ensilage as stated and to the satisfaction of the user. These four machines will cut all kinds of dry feed, and with blower elevator and pipe it can be conveyed to any part of the barn. The perpendicular height from ground to center of opening in silo is ample length of pipe for cutter.

\section{Size of Pulley, Power, Speed and W'eight.}

The pulley is $14 \times 6$-inch face and is leather covered. The necessary power to drive these machines up to capacity and properly elevate the ensilage is as follows: No. 13, 8 to 10 horse-power; No. 16, 10 to 12 horse-power; No. 18, 12 to 16 horse-power; No. 19, 16 horse-power. Speed, 650 revolutions per minute. Weight of No. 13, 850 pouuds; No. 16, 925 pounds; No. 18, 965 pounds; No. 19, 1145, pounds; blower and fan wings, 450 pound; pipe, 4 pounds per foot.

\section{Will Do successful Work With Less Power Than Indicated}

Under ordinary conditions either size will cut and elevate green corn at the rate ' $f$ one ton of ensilage, for each horsepower applied, per hour, The power indicated is necessary to run the machines to full capacity, and it is ample. Some may not have that much power and might not want to provide a sufficient force of men and teams to d liver corn to keep the cutters supplied. The machines are light running, and knowing the power necessary to cut and elevate gree11 corn, parties with less power than indicated can run these machines successfully, and will know how to feed them and what capacity to expect. The only point is to keep the speed up and the machine will do its work. 


\section{GUARANTEE.}

The "Ohio" machines are warravted to be well made of good materials. They will do what is claimed for them if operated according ro instructions, and they are so guaranteed to every purchaser.

THE SILVER MFG. CO., SALEM, OHIO, U. S. A.

Established 1854 .

Catalogues, descriptive matter, testimonials and photographs will be cheerfully furnished on request to the manufacturers. 












\section{LBRARY OF CONGRESS

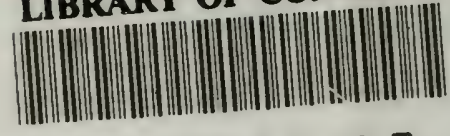 口0027661063}

